PoBErT Morplson

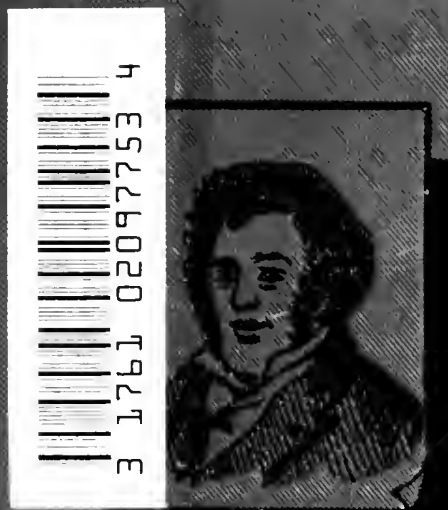

\title{
THE PIONEER
}

OF CHINESE MISSION:

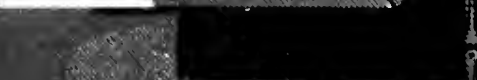

(4)

38
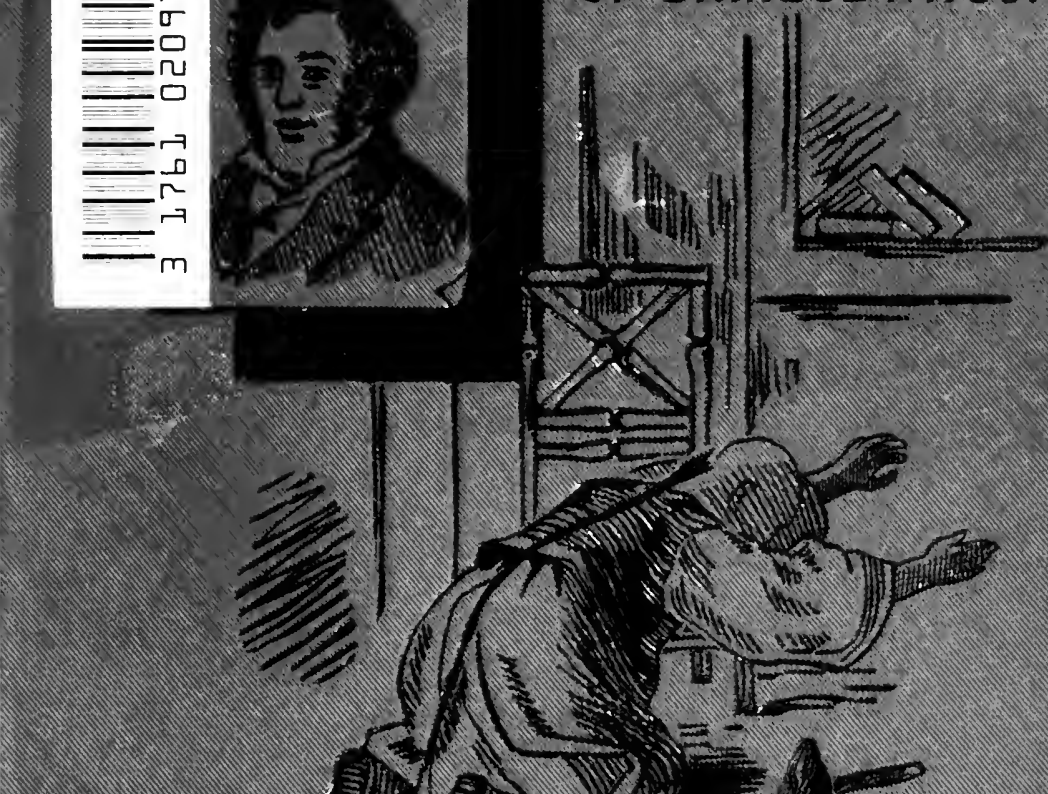

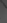

LOWDON MISSIONARY SOCIETY

2. PRESENTATION COPY

$$
z-r
$$


contis.

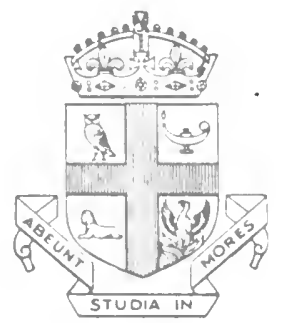

HII: IIBIASY

(i)

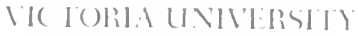

ling(u)ti) 


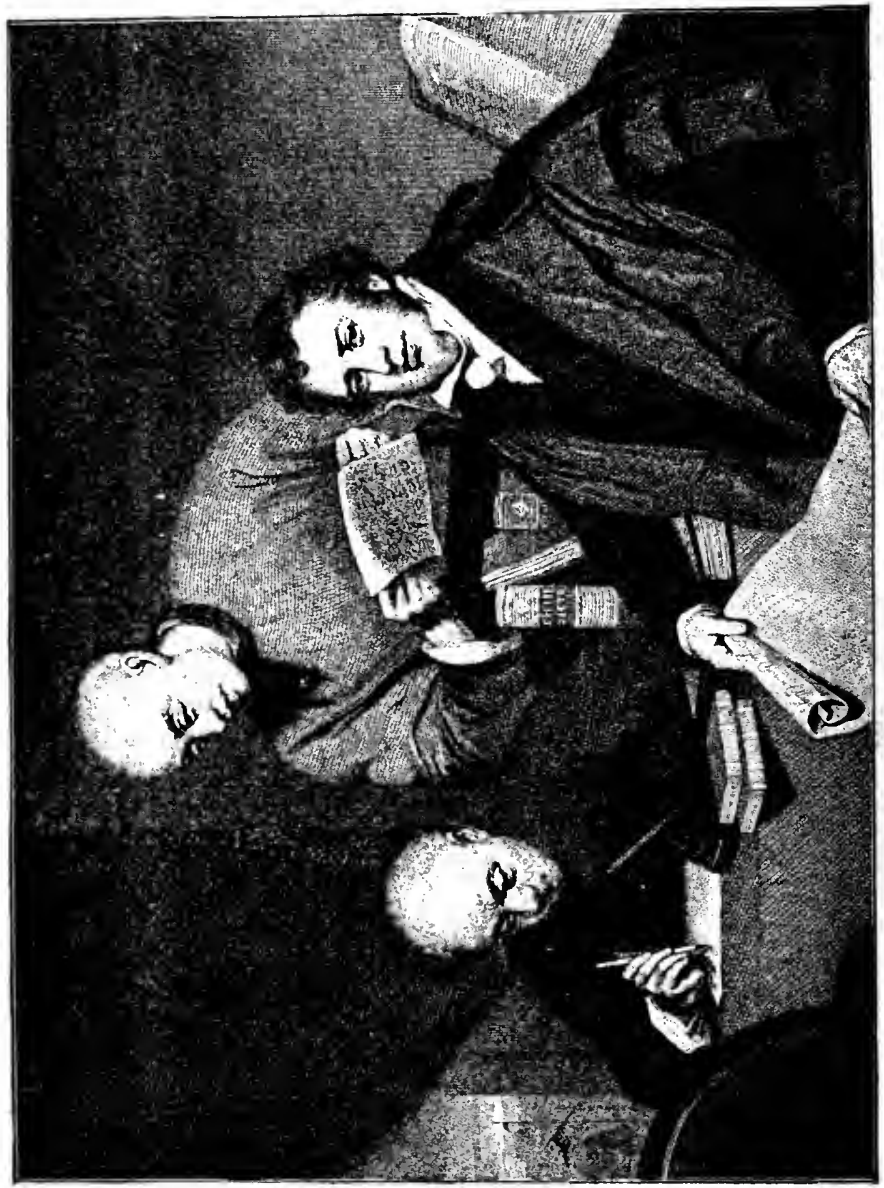

\& ง

3

$\rightarrow$ to

हั่

ऐ

ट

용

. ¿

ค

- 인

i

员 0

$\approx=x$

है

स है

- के

कै ह

¿

$\simeq \leq$

$>2$

2

요

I

I 


\section{ROBERT MORRISON}

THE

gevionecr of Cbinese 嗮lissions

$B Y$

WILLIAM JOHN TOWNSEND

ACTHOR OF "THE GREAT SCHOOLMEN OF THE MIDDLE AGES"

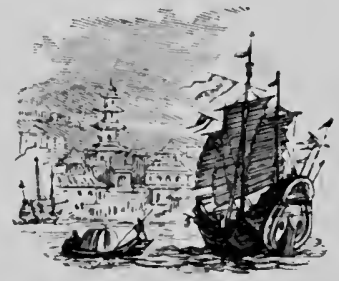

Ẽondon Attissionaty Socictñ's Edition

\section{LONDON}

S. W. PARTRIDGE \& Co., 9, Paternoster Row 
SV

$24 \%$

.11676

EMAiAAivuel

FRINTED BY
HAZRLL, WATSON, AND VINHY, I.D.,
LONHON AND AYLESETRY.

, (4) 159510 


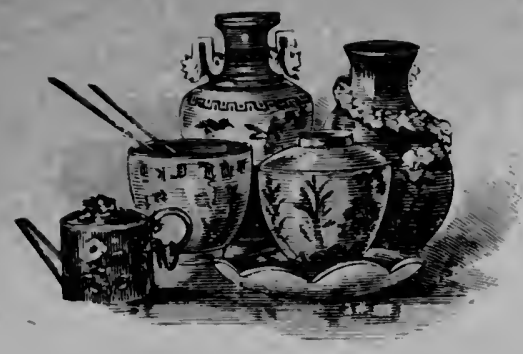

PREFACE.

THE ever-growing interest now being manifested 1 in the evangelisation of the Chinese Empire has created a farourable opportunity for issuing a bricf memoir of the first Protestant missionary to that country, and thereby extending a knowledge of his life and character amongst the young of our Churches and Sunday Schools.

This present enlarged edition is prepared specially for circulation amongst the Sunday Schools and Juvenile Missionary Associations of the London Missionary Society, and it is hoped that the spirit of the subject of this memoir may rest abundantly on the youth of this generation.

The Author has collected the materials of the book from sources too numcrous to be mentioned, but he desires to express his fervent thanks to Mrs. Hobson, the aged and amiable surviving 
daughter of Dr. Morrison, who has kindly allowed him to have access to and make extracts from many letters of Dr. Morrison not hitherto published, and to his revered friend, the Rev. J. C. Bruce, D.D., for a similar favour, and also for the use of an unpublished lecture on "Morrison and Chinese Missions," given by him in Newcastlc-upon-Tyne in 1859 .

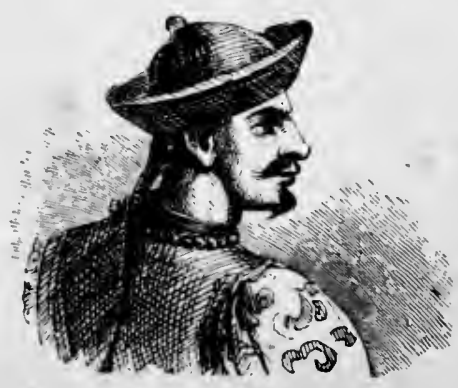




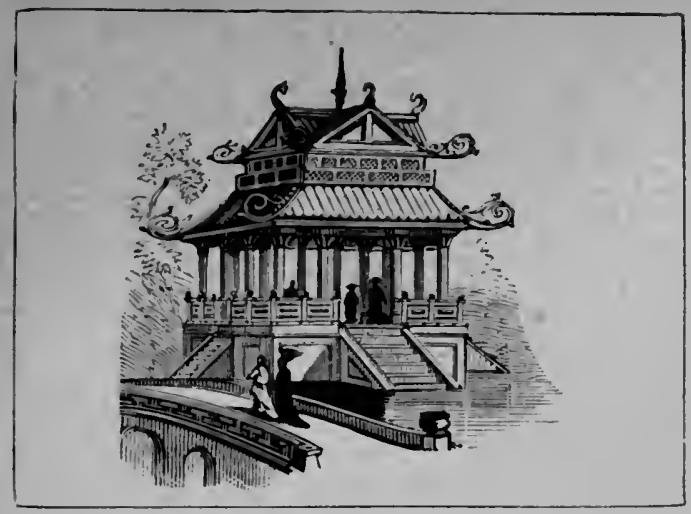

CONTENTS.

PAGE

CIIAPTER I.

CIIINA AND ITS PEOPLE

CIIAP'TER II.

THE RELIGIONS OF CIINA • . . • . • . 22

CIIAPTEK III.

EARLY ATIEMPTS TO EVANGELISE CHINA • • • • 33

CHAPTEK IV.

ROBERT MORRISON : CHHLDHOOD AND YOUT11 . . . 41

CHAPTEK V.

PREPARATION FOIR TIIE GREAT WORK . . . . 51

CIIATER VI.

INITIAL LIFE AND WORK IN CHINA . . . . . 67

CHAPTER VII.

PERSECUTION.-LONGING FOR SUCCESS . . . . $\delta_{j}$ 
CHAPTER VIII.

A FELLOW-LABOURER • • • • . . . . . 99

CHAP'TER IX.

VISIT TO PEKIN,-COLLEGE AT MALACCA • , + $~ I 12$

CHAPTER X.

CIINESE BIBLE COMPLETED.-DR. MILNE'S DEATII • - 128

CHAPTER XE.

WORK IN ENGLAND

CIIAPTER XII.

LETTERS TO IIIS CHILDREN • . • • • • • 175

CHAPTER XIII.

RENEWED LABOUR

CIIAPTER XIV.

WHAT IHE WAS AND WHAT HE DID

- . . 213

CHAPTER XV.

TIIE LONDON MISSIONARY SOCIETY • . . . . 218

CHAPTER XVI.

CONTINUANCE OF TIIE WORK: AMERICAN AND CONTINENTAL SOCIETIES . . . . . . . . . 232

CIAPTEK XVII.

CONTINUANCE OF THE WURK: BRITISI SOCIETIES . . 241

CHAPTER XVII.

TIE OPIUM TRADE OF CHINA $\cdot$ -
CHAPTER XIX.

CIINA FOR CIIRIST • • • • • • • . 258 


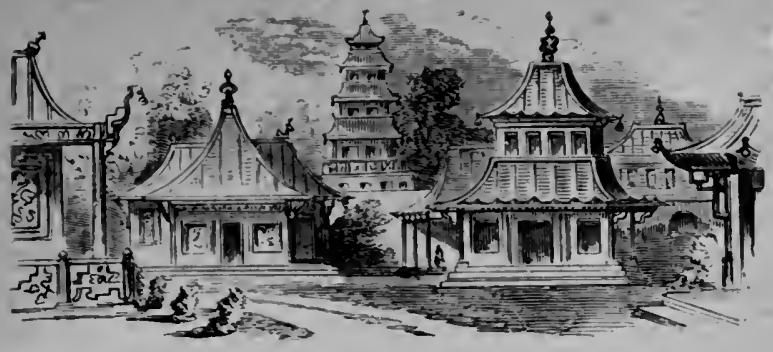

\section{ROBERT MORRISON.}

\section{CHAPTER I. \\ CIIINA AND ITS PEOPLE.}

"It is Christ alone can lead in the glorious dawn of the Chinese renaissance, the new birth of a mighty nation to liberty and righteousness and an ever-expanding civilisation."-G. JoHs.

CHINA is a great empire situated in Eastern Asia, lying from $20^{\circ}$ to $40^{\circ}$ north latitude, and from $100^{\circ}$ to $122^{\circ}$ east longitude. It is a wonderfully compact territory, its length and breadth being nearly equal. It includes more than a million square miles, and possesses, on the whole, an excellent climate. Two noble rivers flow down its centre, watering and fertilising its extended plains and beautiful valleys. The ocean, adorned with numerous islands, washes round its eastern and southern coasts; the mountains of Thibet bound it upon the west, and the north is protected by a wall thirteen hundred miles in length. Much of this wall is now crumbling away, but it took the united labours of the nation to build it two thousand years ago. Beyond these mountains and this great wall are bleak deserts and sterile wastes, forming a contrast so striking to the general fertility of the country, that the Chinese 
have from remote ages called their teeming soil "The Flowery Land." Extensive as is the surface of China its immense population requires every inch. From the late imperial census the number of the people is estimated at three hundred and ninety-two millions, or more than onequarter of the earth's inhabitants. To accommodate such a number every scrap of space requires to be economised, and therefore the people are packed together in houses and corners in a way that is astonishing to our Western ideas. Crops are sown and gathered on tiny and almost inaccessible

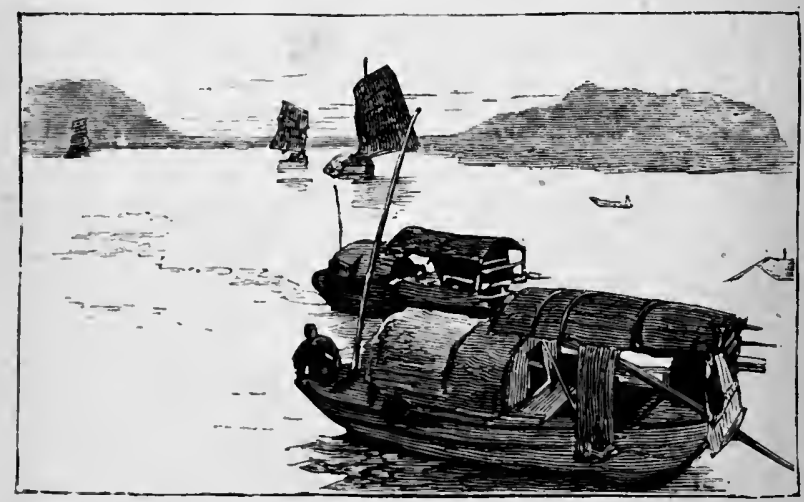

CHINESE HUUSELUAI.

spaces, thus utilising every possible foot of the land. The Chinese gather two crops a year from their fruitful fields; and that the more land may be left for cultivation the people in large numbers live on the water, and the surface of the great rivers presents the appearance of floating villages. This economy is the more needful as there are large tracts in China which cannot be cultivated. There are grand mountain ranges to the west, with stern lofty peaks and frowning sides, varied with slopes covered with cedar and pine forests. The centre provinces are hilly, interspersed with fertile plains, where the tea plant flourishes luxuriantly; 
whilst to the east ard all round the extensive seaboard are flourishing cities and seaports, the centres and outlets for numberless villages and wide agricultural districts, which give these provinces an aspect of a garden of the Lord.

China is the home of a very ancient and advanced civilisation. Its inhabitants were clothed in their silken and linen fabrics when our forefathers were simply staining their skins with woad. They had their great cities when the tribes of Britain rambled in primeval forests. They manufactured paper nine hundred years before Europe had discovered the useful art. They invented printing at least five hundred years before the Dutchman took the impression of the letters he had carved upon the tree. They had used the mariner's compass for five centuries before Marco Polo brought it into Europe. They had an extensive manufacture of pottery and porcelain ages before the elegant forms of Grecian or Etruscan pottery were moulded. They were acquainted with abstruse philosophies and curious sciences before the Republic of Rome had arisen. From hoar antiquity popular education had existed in the land, and by a system of competitive examinations every office of the State has been thrown open even to the poorest. Thus China, as a great and civilised nation, comes down the stream of time side by side with the ancient empires of Egypt, Assyria, and India. These passed away, and there succeeded the splendid empires of Greece and Rome, and these again have been followed by the young, fresh nations of Europe and America. But China has not passed away, as its early contemporaries did, but is to-day as populous, as strong, and as promising in regard to the future as it has ever been.

It is true that the civilisation of China has been arrested in its growth. All progress comes from a sense of shortcoming, and the Chinese long since imbibed the paralysing notion that they had attained perfection, and styled themselves "The Celestial Empire." 'This was fatal to all further 


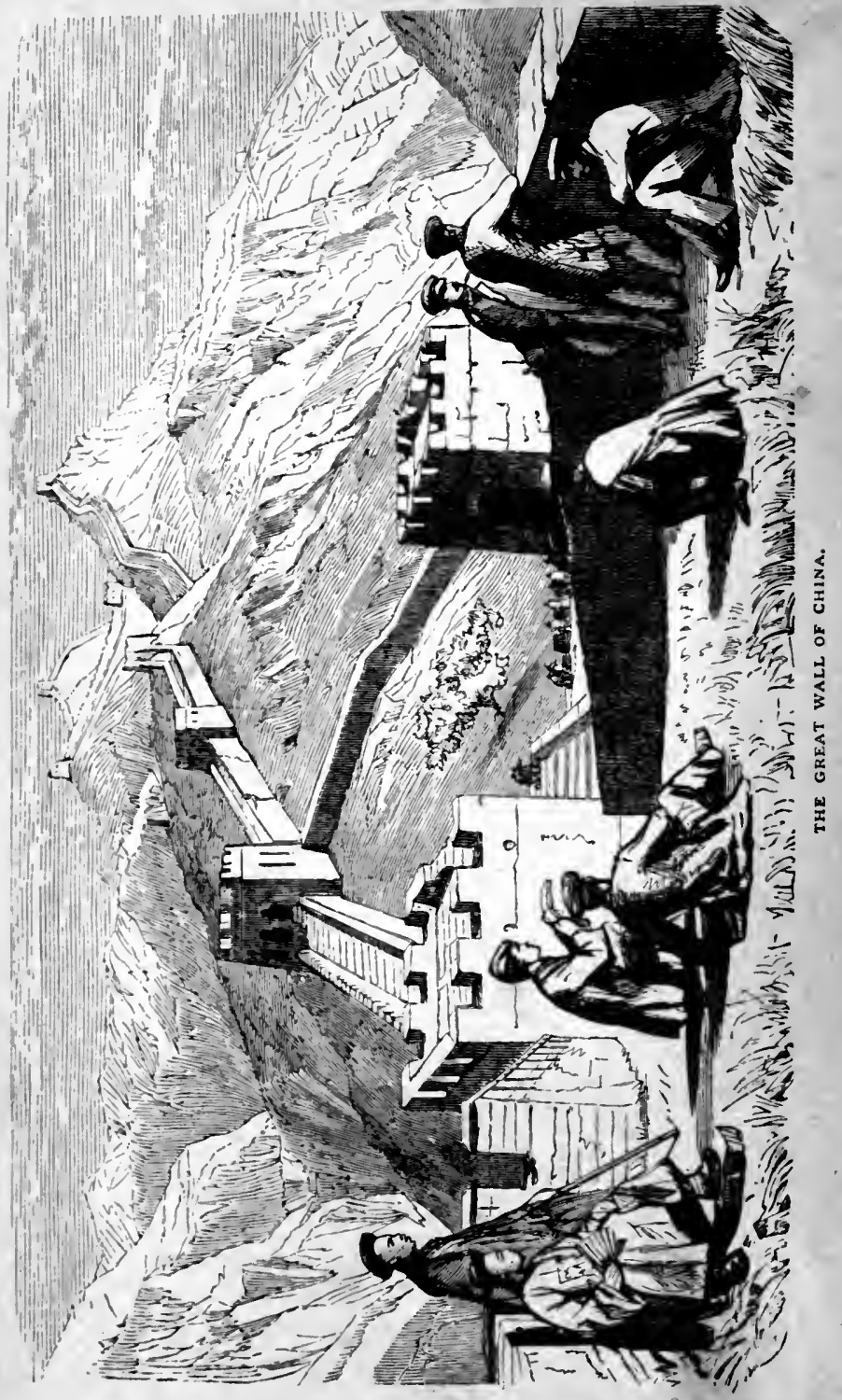


growth, and therefore the Chinaman despises all things that are called new, and, with his head turned the wrong way, looks to and worships the past. Old forms and patterns are therefore endlessly reproduced in manufactures, old customs are jealously guarded, and the intellectual growth of the people has long since stopped. Nor is this all; for as the Chinese have become simply a nation of imitators, they are being left behind in the march of progress not only by Western nations, but by the more progressive peoples of the East, who welcome and cultivate modern ideas and inventions with great advantage to their development and prosperity.

The people are quiet, peaceful, and law-abiding; they are outwardly and ceremoniously polite; they are industrious in their habits and refined in their tone. Like all heathen nations, they are deeply sunken in vice, but their vices take the milder rather than the ruder forms. 'They are shamefully sensual, dishonest, and untruthful, but they are not violent or cruel; and, unlike the warlike nations of the West, they have generally sought to avoid war, and to live undisturbed on their own homestead. They have cultivated the home and family sentiment beyond all other peoples, and yet, in common with other Eastern nations, they have so low an estimate of women as to expose to death in large numbers their female babies. Many of their social habits are in strange contrast to ours. When we meet our friends we shake their hands; they shake their own hands. We salute our friends by wishing them "Goodmorning " or "Good-evening;" they salute theirs by asking questions, "Have you eaten rice?" "Will you drink tea?" "Is your father living?" "How many children have you?" In the presence of our superiors we uncover our heads; they cover theirs. We treat our women as our equals; they reckon them the foolish ones of the family, and relegate them to the inner rooms of the house. Our badge of mourning is black, theirs is white. They mourn for the dead by 
proxy; we sorrow for ourselves. We read and write from left to right, horizontally; they do so from right to left, perpendicularly. Our women pinch in their waists; they bind and dwarf the feet. Our place of honour is the right, theirs is the left. Our young people select their own husbands or wives; their parents decide who their children shall marry. We eat with knives and forks, they with chopsticks. WVe

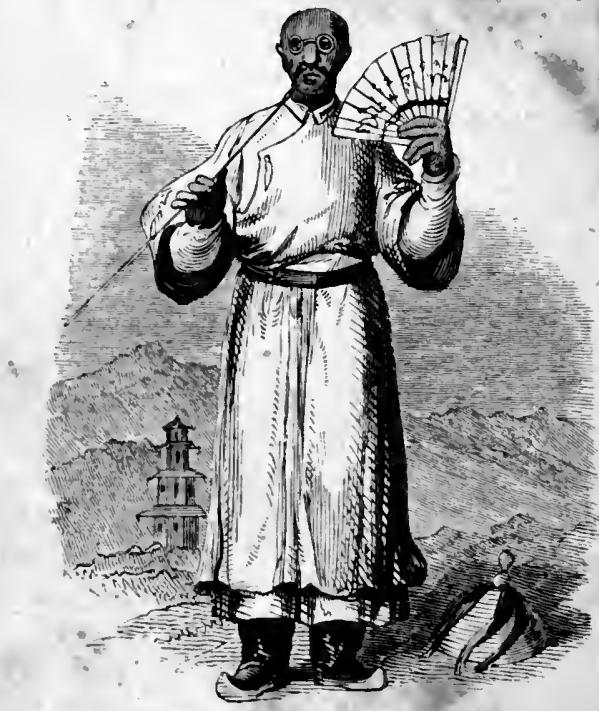

CHINESE MANDARIN IN SUMMER DRESS.

page our books at the top of the page, they on the margin. We print on both sides of the page, they only on one side. We put the title of a book on the back of the binding, they on the margin of the leaf. We set our volumes on the edge, they lay theirs down. We educate our girls, they put them to service. We carry out our manufactures largely by machinery; they work by hand. IVe print by a press, and with marvellous rapidity; they print slowly, with wooden blocks and a hand-brush. So it is with many other things; 


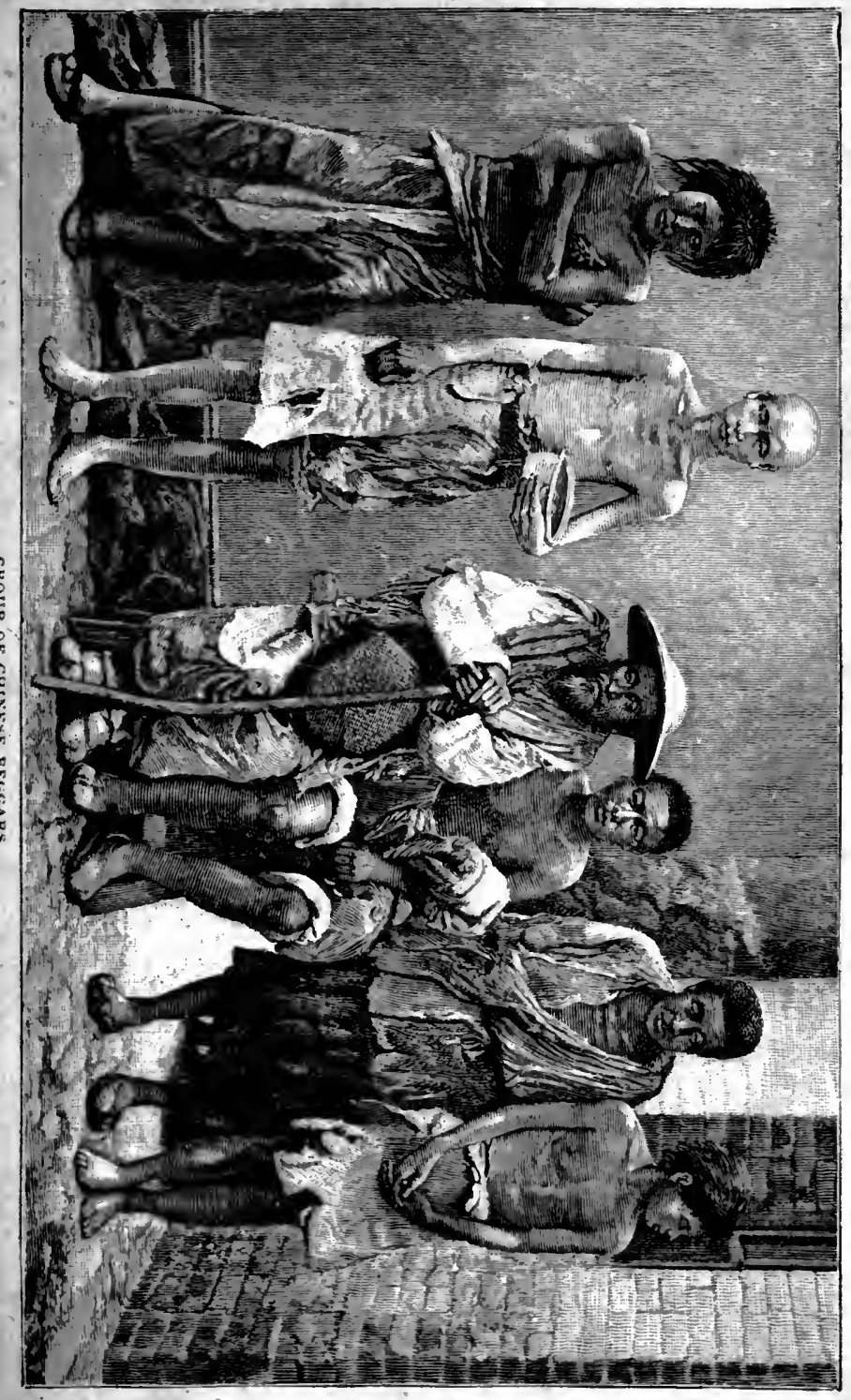


all showing how much they differ from, or how far they are behind, the Western nations of the world.

Their garments are made of satin, silk, cotton, hemp, the grass of the field, and the feathers of birds. The men wear a long pigtail, a broad-sleeved coat, and wide trousers; the women wear an embroidered skirt, loose-fitting jacket, and tiny shoes. The patterns of their clothes are uniform and old-fashioned, but they are made for ease and convenience

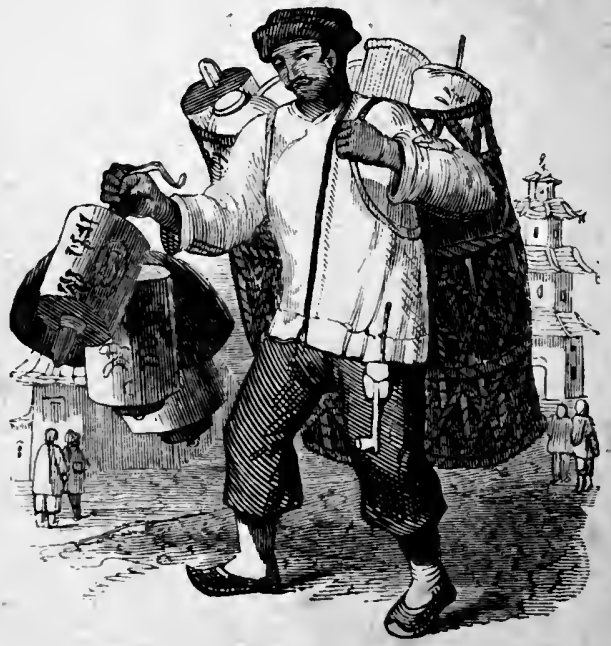

LANTERN SELLER.

rather than for ornament; and in this respect they show more sense than we do.

The dwellings of the common people are poor and filthy. They contain usually but one room with one window. They are built of stone, or bricks, or mud, according to the means of the family; but the Chinaman easily adapts himself to circumstances, and will sleep soundly in any corner on land or water. Their food is various ; but they eat fowls, fish, puppies, rats, and cats. 
They grow and consume rice, maize, millet, wheat, and barley; they cultivate potatoes, turnips, tomatoes, pears, peaches, grapes, guavas, pineapples, and pomegranates, with many other fruits. The upper classes are rich, many of them enormously so; the common people are poor, so that if the Yellow River inundates a province or a harvest fails it means starvation and death to millions, and beggars, reduced to skin and bone, and many sorely afflicted, swarm in every part of the land.

The language of the Chinese is a difficult and singular one to Englishmen. It has no conjugations or declensions, no affixes or terminals, no syllables or alphabet. It is made up of upwards of forty thousand symbols or characters, many of which have the same sound, but several meanings, the difference between which can only be known by observing the tone, or emphasis, or inflexion with which it is accompanied. 'The forty thousand characters are arranged in two hundred and fourteen classes, each class being placed under a certain root, which forms a component part of each character in its class. This somewhat simplifies the finding of words in the dictionary, and helps to impress them on the memory. Although it is an unwieldy and inconvenient language, and contains many dialects within itself, yet the written language is the same in all Chinese-speaking nations. 'Thus, in mastering it, we have a key wherewith to reach not China only but Japan, the Corea, Cochin China, the numcrous races beyond the Great Wall, and the millions of Chinese in Siam, Borneo, and the inhabitants of the Straits Settlements, not to speak of the enigrants in Australia, California, and India. No language was ever so widely diffused or so largely used, and probably, with the single exception of Hebrew, it is the oldest upon the face of the earth.

The Chinese are a merry-making people, and have numerous holidays and festivals, into which they enter with extraordinary zest. 'The chicf of these is the New Year festival. It is elaborately prepared for ; and before it arrives 
houses, shops, and public buildings are cleaned and decorated, illuminations are arranged, and holiday attire provided. When it dawns business is suspended, and there are nothing but salutations, visits, feastings, and rejoicings, which continue for ten days. Then there is the feast of "Welcoming the Spring," observed by civic processions and ceremonies, ploughing a furrow by prefects or other officials, and offering sacrifices. The "Festival of the Tombs" is the occasion of sacrificing to the spirits of the dead, and often takes the form of a family excursion, by boat or road, to the hills, where reverent services are held, followed by great feastings. Many other popular holidays occur, prominent among which is the "Feast of Lanterns," held in the autumn. This is to propitiate the spirits of those who have been drowned, and to please the water-gods of China. Long processions of boats, each covered with rows of lanterns, glide over the rivers, while Taoist priests, arrayed in scarlet and embroidered robes, offer prayers and beat gongs to secure the goodwill of the deities, and cast gilt paper, burning, into the streams. It is a splendid scenic effect.

A great feast is held when a son is married. Relatives assemble at the bridegroom's house to drink and rejoice. The bride, after elaborate preparation, is taken from her home, shut up in a Sedan chair, and carried to her future husband's home. When she arrives there fireworks are sent up, and revelry commences. The bride conceals her face from public view, holding her hands in a semicircle before her head, and allowing the broad sleeves of her wedding dress to hang before her features. Thus supported by two attendants, she goes round, as tea is presented to the guests, receiving compliments, and bowing in response. Coarse jests pass fron lip to lip, and often efforts are made to trip up the bride as she goes about, or to pull down her wearied arms so as to expose her face; and if she manifest any impatience on such occasions, it is reckoned as an augury of 


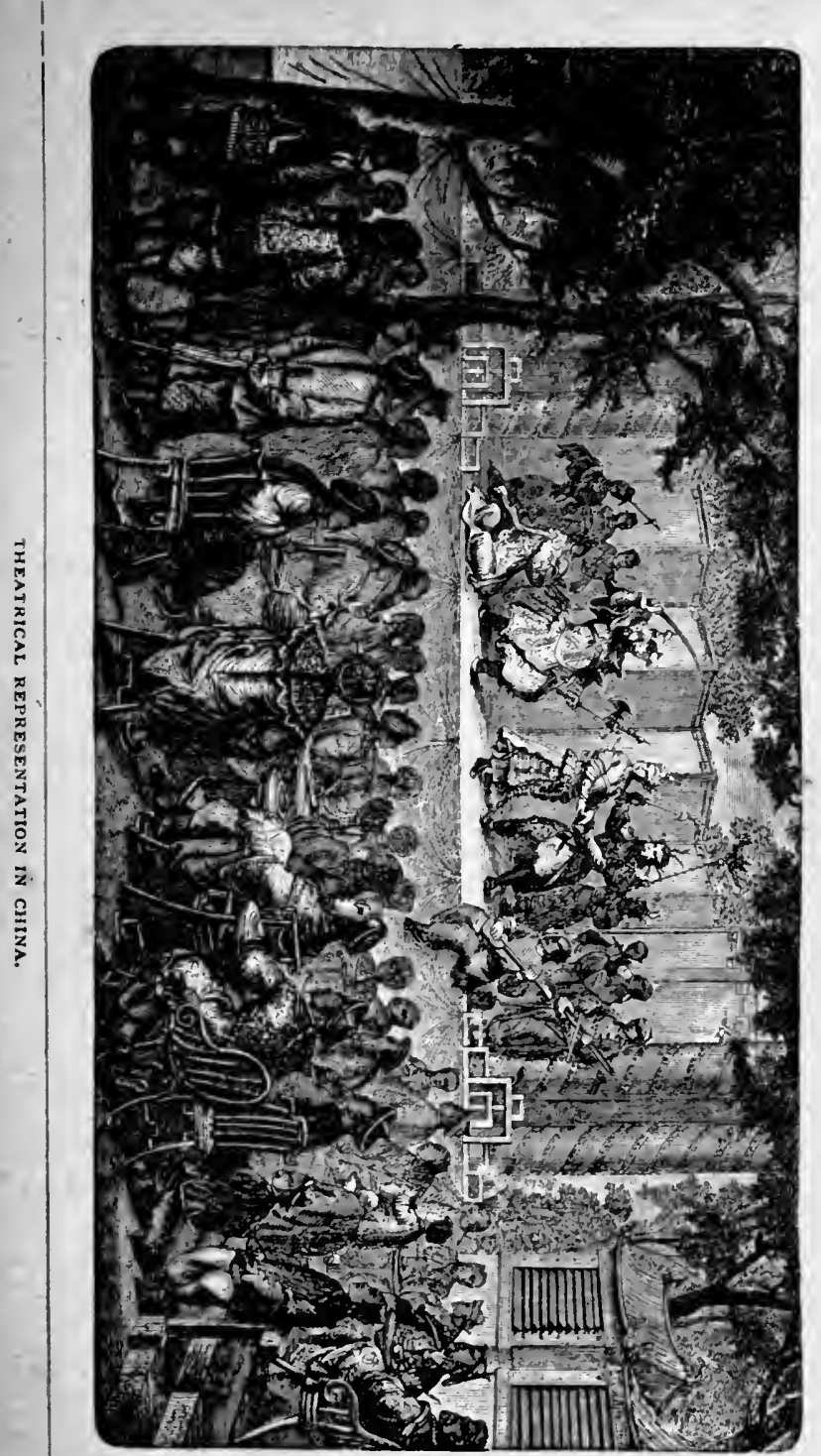


an unhappy career, and the bridegroom is condoled with on the prospect before him.

Theatres abound in China. Not magnificent buildings like those we have in our cities, but slight movable constructions of bamboo poles, covered with sheets of matting, painted red, and roofed with palm leaves woven together. Stage and galleries are formed of rough boards placed on bamboo sticks, and accommodation is often provided for a thousand people. The plays are so long that sometimes they will require several weeks for their presentation; but they can be abbreviated at the will of the manager or the audience. It is a curious scene. The actors are dressed in gaudy colours, with false beards, they recite their parts in the absurdest fashion, and a deafening sounding of gongs and cymbals fills up every interval. These travelling performances are immensely popular in China.

The capital city of China is Pekin, which contains the enormous population of about two millions. It is in the north, in the province of Chih-li. There are the Palace of the Emperor, the seat of Government, and the Temple of Heaven, where once a year, as the high-priest of the nation, the Emperor offers worship and sacrifice. Here idols and coloured glass are manufactured, and extensive printing works are in operation. Canton is in the south, and contains a population of a million and a quarter. The provinces of the south are largely cultivated for rice-growing, and also for the growing of the mulberry plant and the breeding of silkworms. In the city of Canton there are great manufactories in iron, brass, and stone. Hankow, an inland city, situated on the river Yang-tse-Kiang, is the centre of the great tea trade. Foochow exports tea, timber, and bamboo. Amoy manufactures porcelain and paper. Nankin was the old capital of the empire and the centre of the silk and nankeen manufactures; but it is now decaying, and these trades are migrating elsewhere. Hong Kong is an island at the mouth of the Canton river, which was ceded to England 
in 1843 , and from which the trade of England with China is superintended. The great Chinese Canal is the longest in the world, being seven hundred miles in length, and by it the products of the north-eastern provinces are brought up to the northern seaboard.

All over the land are great cities, which teem with life. Rivers and canals throughout the provinces are lined with towns and cities, many of which are filled with populations numbering from one hundred thousand to half a million. In the north, coal and silver mines are being opened and vigorously worked. Here also railways, telegraphs, telephones, and other wonders of modern times are being introduced, all foretelling a day of increased commercial prosperity and importance to the old hoary land.

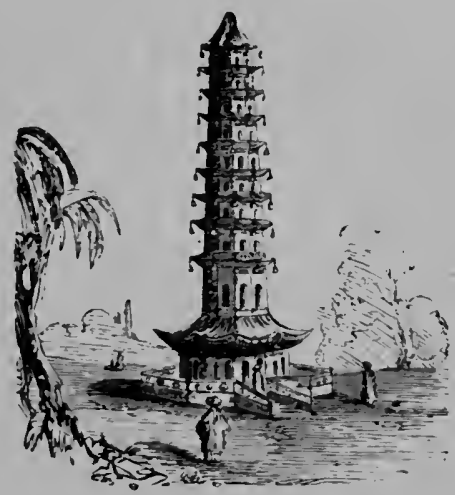




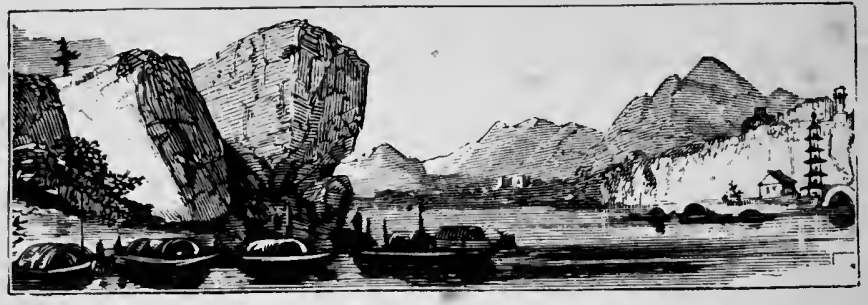

\section{CHAPTER II.}

THE RELIGIONS OF CHINA.

-While a slave bewails his fetters,

While an orphan pleads in vain, While an infant lisps his letters,

Heir of all the age's gain,

While a lip grows ripe for kissing,

While a moan from man is wrung,

Know by every want and blessing,

That the world is young."

KINGSLEY.

T $\mathrm{T}$ is probable that in the early history of the Chinese empire correct ideas of the true God were maintained, but these were lost in the idol worship which afterwards prevailed universally. The images and idols of China are now innumerable. There are gods of the heavens and earth, of the stars and planets, of the rains and winds, of the seasons, of mountains, pastures, rivers, and lakes, of thunder and lightning, of fire and cold, of wealth and war, of commerce and agriculture, of every trade, profession, and calling, and even evil spirits are worshipped, because the Chinese say that to worship a good god is of no use, because he will not harm you, but it is very important to keep right with the evil one. 
While China is a nation of idolaters, there are three great religions into which they may be distributed. These are Confucianism, Buddhism, and Taoism. The first of these is derived from Confucius, who lived about $55^{\circ}$ B.c. $\mathrm{He}$ was born in the province of Shantung, and was the son of a statesman. He founded rather a system of moral philosophy than a religion, for his teaching has no reference to a Supreme Being who is to be worshipped, or to a soul that needs to be saved from $\sin$. He gave utterance chiefly to moral maxims, some of which seem to be related to the Proverbs of Solomon, and inculcate a lofty tone of virtue.

Confucius lost his father when three years old, and he passed his youth in obscurity and comparative poverty. As he grew up he gave himself to diligent study, and at the age of twenty-four resolved to devote himself to the improvement of his countrymen in knowledge and virtue. With this object he issued books expounding his views, and in course of time he had trained three thousand pupils, some of whom became the preachers of his doctrines throughout the nation. He travelled throughout the land, speaking much in the open air, and, like other sages and prophets, drawing many lessons and illustrations from common life and from the objects of nature.

After many years spent thus he returned to his native province, where his house became a common resort for the thoughtful and inquiring. Unlike Socrates, who taught largely by asking questions of his pupils, Confucius encouraged those who sought his instruction to question him on all subjects of morals, politics, or literature. His pupils were earnestly attached to him, and propagated his opinions throughout the whole country. He was afterwards appointed chief minister of State, and carried out many reforms in the administration, giving encouragement to trade and industry, and greatly increasing the prosperity of the people. But jealousy and opposition arose against him, he retired into private life, and for more than ten ycars happily devoted 
himself to literature. When he felt his end was approaching he summoned his disciples to a hill in the neighbourhood of his dwelling, built an altar, on which he placed his books, then, kneeling with his face towards the north, he gave thanks that he had been able to complete the work given him to do, and implored a blessing on his country from his

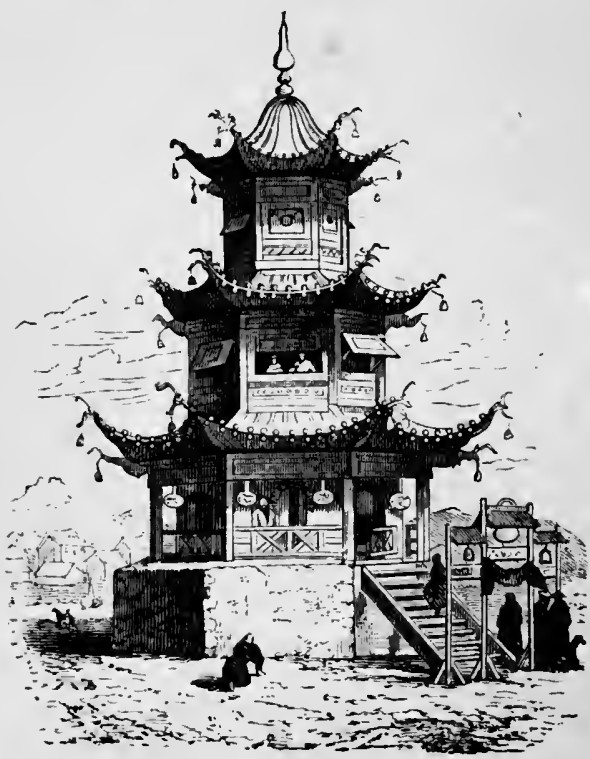

ANCIENT CHINESE TEMPLE.

labours. He died at the age of seventy-two years, 479 в.c. He lived in a great period of the world's history, during which the Jews returned from captivity, the second temple was built, Greece was invaded by Xerxes, Egypt was conquered by the Assyrians, the Persian empire was firmly es'ablished, and within seven years of which Socrates, perhaps the only superior to Confucius in the heathen world, was born.

His system, both of morals and national economy, was 


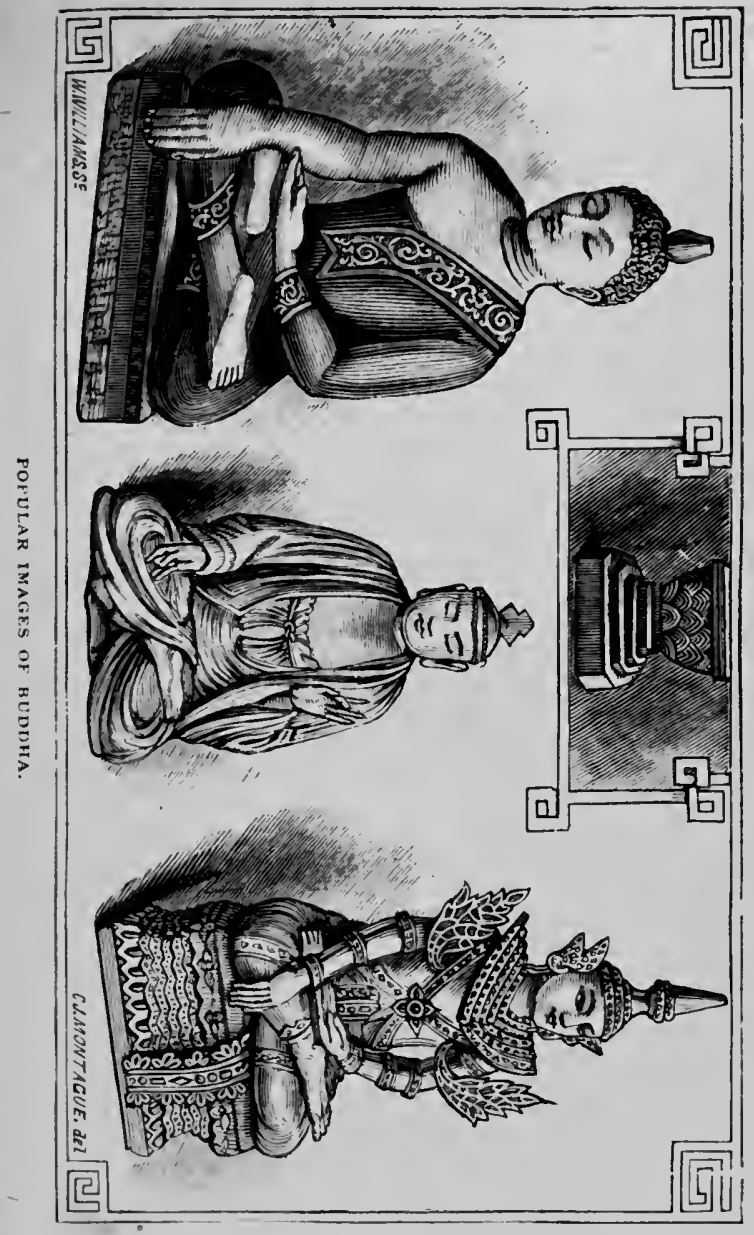


founded upon the sentiment of filial piety. From the reverence and obedience due from the child to the parent he educed the obligations binding upon all ages and all classes in the State. He enforced the principles of honesty, justice, and benevolence, but also he permitted, or inculcated, idolatry, polygamy, and the bitterest revenge. He became the favourite and adored sage of the empire. His name is intensely reverenced, his sayings are household words, his writings are text-books in every school, his principles are professedly practised by every civil official in the land. He lived a noble life, and left behind him a grand heritage to his countrymen. Temples are built everywhere, and worship offered to his memory. His system, whilst pure and elevating in many respects, yet leaves quite untouched the great truths of a Deity, a future life, the real nature of sin, or the means of human salvation. Confucianism is the State religion of China. It has for its votaries nearly all the scholars, the officials, and Government agents, many of whom, however, unite with the profession of Confucianism the rites and observances of other religious systems.

Buddhism is the great religion of Eastern Asia. It was introduced into China about A.D. 60 in a curious and interesting manner. The Emperor, prompted; it is said, by a dream of the night, sent messengers to the West to seek for a knowledge of the true religion. Confucius had long before stated that in the West a great and holy sage would arise, and such a dream might have sprung out of this saying. The messengers proceeded on their errand as far as India, and there met with Buddhist priests, who imparted to them a knowledge of Buddha and his doctrines. They concluded they had obtained what they sought, and returned home with a new god and a new religion for their countrymen.

Buddhism was founded by Sakya-mouni, or the Wise Man, who lived about seven centuries B.c. The life and 
history of this sage is surrounded with a haze of myth and romance. He is said to have been an Indian prince, who turned from the pomps and vanities of a palace, and devoted himself to a life of meditation, of works of mercy, and of self-inflicted privations and tortures, until he reached the state of Buddha, or "perfect knowledge." From this he taught that men might pass into a higher state called "Nirvana," in which they lose personality, pass from relations and intercourse with material things, and lose all individual desires; in short, in which human nature is annihilated. Buddha, however, lingers on the verge of this highest state, denying himself its repose in order to proinote human happiness and lessen the sum of human misery.

Buddhism teaches the existence of a benevolent Deity, surrounded with lesser ones, who seek to save men from the practice and consequences of sin. It inculcates belicf in the transmigration of souls and the doctrine of human merit. Flowing from these teachings there come prayers and offerings to the numberless gods of the system, works of penance and merit, the offering of presents for the supposed nceds of spirits in Hades, and for their departed friends.

Temples for the worship of Buddha are scattered all over the land. Many of them are splendid and costly buildings. As the system is promotive of habits of quiet meditation, they are chiefly situated amidst the hills or in secluded valleys, and are charming for their natural surroundings. Idols, representing the many gods of the system, fill up these temples, several hundreds being sometimes found in one building. Some of the temples have pagodas connected with them. These are graceful towers built of stone or brick, in some special cases of porcelain, and rising from eighty to two hundred feet in height. The idols are made of many materials-of bronze or brass, or other metals, of stone, wood, clay, and pottery. The images of Buddha represent a human figure with a sleepy countenance, having 
the toes and fingers of equal length, and the ears reaching to the shoulders. Besides the images found in the temples and joss houses they may be found in private houses, on doorsteps, in porticoes, or almost anywhere, thus giving sad proof of the extent to which the minds of the Chinese are given to idolatry.

Buddhist priests swarm in China, and in many of their practices resemble the priests of Romanism. They shave the head, they profess to fast, they are not permitted to marry, they recite prayers, they receive and appropriate the offerings presented in the temples, and they perform a service morning and evening. They attend funerals and festivals to preach or to tell stories, and often are engaged to officiate on such occasions in private houses. They are daily and importunate beggars, and make their own garments. Nunneries are also prevalent in China, and in these companies of women associate, who shave the head, pass through rounds of religious rites, and train the novitiates who have entered their institution.

Buddhism is by far the most popular religion in China, and is a system which is marvellously adapted to the condition and circumstances of human nature. It recognises the religious longings, the depraved habits and the distressing miseries of the race of man; but by diverting the religious clement in man into gross idolatry it leads the soul from the true God, by teaching the doctrine of merit it fosters human pride and self-sufficiency, and by teaching the doctrine of final annihilation as an escape from misery it plunges the mind into the darkness of despair.

Taoism, although much inferior to the preceding, both in the weight of its influence and the number of its adherents, is the third great religion of China. Its founder was Laotse, a philosopher who was born 604 B.c. $\mathrm{He}$ composed a book called "A Treatise on Truth and Virtue," which is reckoned as a leading classic in Chinese literature. The word "Tao," meaning Truth, is derived 
from the leading name in the title of the book, and is the subject chiefly enlarged upon. It is said that Confucius visited Laotse and discussed important subjects with hin. Taoism has greatly degenerated from the simplicity of its early history. It has become corrupted by superstitions, it has absorbed many of the vagaries of astrology and alchemy, reading the stars, secking for the elixir of life and the philosopher's stone, and is now a form of the grossest idolatry. In its root it is a system of pure materialism. It teaches that matter is eternal, that its grosser forms tend downwards, and become the substance of the earth, while its finer essences tend upwards, and become possessed of individuality and life. The stars are some of these, which have assumed visible forms, and look down with interest upon the earth. 'The body and soul of man also represent the more gross and refined essences or principles of nature.

This system declares Laotse to have been a living principle pervading space long before the creation of the heavens

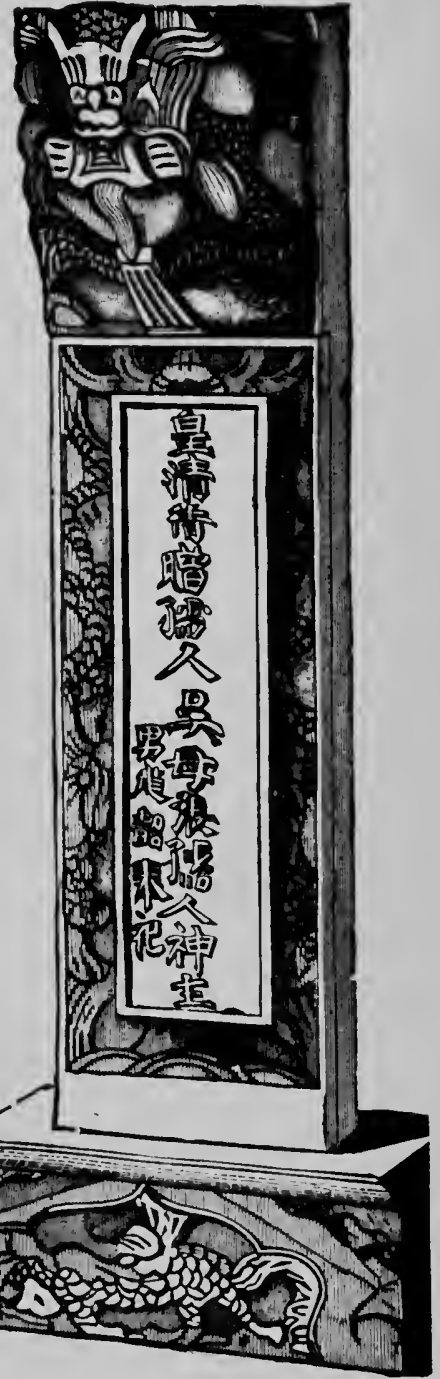

ANCFSTRAL TABLET. 
and the earth. In the course of long ages this principle developed into a Deity, called the "Holy Ruler of Wonderful Identity." "After further prolonged ages this Deity emerged as the "Holy Ruler of Wonderful Entity," and by-and-by a third evolution produced the "Holy Ruler of Chaotic Confusion." Beginning with this chaotic jargon, there is taught a system of semi-pantheism. Laotse is said, after the appearance of man upon the earth, to have lived under the names and persons of several great sages and prophets, and finally to have been born of a virgin. His hair was white with old age at his birth, and his votaries claim for him the possession of the most astounding qualities and powers. He is now worshipped with many other gods and deified sages, for Taoism, like Buddhism, has invented deities for every occasion and for almost every locality. Amongst its gods must be mentioned the dragon, whose domain includes seas, lakes, rivers, and ponds, with all their living creatures. All the varied phenomena of clouds and rainfalls are also supposed to be under his control. In his realm are said to be innumerable lesser dragons, who are his subjects and agents. References to other gods of this religion might be multiplied indefinitely, but space will not permit.

Taoism is preferred by the rulers of China to Buddhism, because of its native origin. Therefore its priests and ceremonies are employed in the State worship. Its temples and priests are comparatively few, and women are not attracted to its worship in crowds as they are to Buddhism. It deals too much in mere abstruse speculation to be generally popular, although, as if to illustrate the curious meeting of extremes, it has long practised all the forms of modern spiritualism, with its rappings and table turnings. In all public places in China its mediums are to be found, who, for a small payment, may be consulted on the future world, or departed friends, or events which are transpiring in other parts of the world. There are certain idolatrous practices common to all these religions which interlink them 


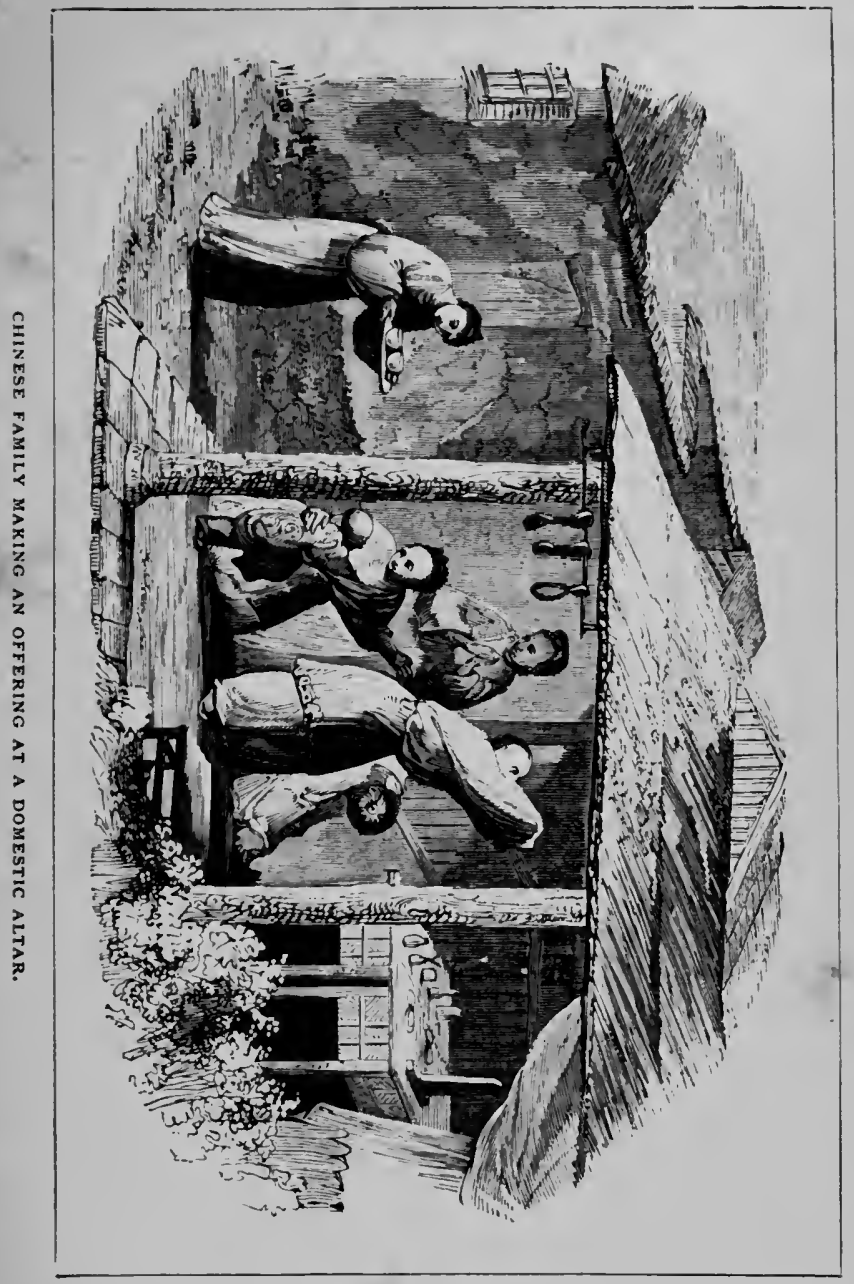


in the history and belief of the nation. The chief of these, and the only one requiring notice at present, as being the most deeply rooted in the religious life of China, and forming the most formidable obstacle to the spread of Christianity, is Ancestral Worship. Its rites are looked upon as being an indispensable element of filial piety, and every person in the nation has the duty enforced upon him of observing these forns in the most positive manner. Each family is expected to preserve ancestral tablets or paintings for this purpose. The ancestral tablets are made of wood, and are about twelve inches long. They are inscribed with the names and titles of the dead, the dates of their birth and death, and the names of their sons. The paintings are taken after death, and seldom can be reckoned as faithful portraits. These tablets are brought out and worshipped at the new year and on the birthdays of the deceased. The worship of ancestors consists of prostrations, offerings of cooked foods, burning of incense, candles, and paper-money, and sometimes dramatic performances are gone through. The worship may be offered at will in the dwelling-house, or the family temple, or at the grave.

In all the religions of China there is nothing which efficiently restrains from the practice of evil or enables a man to lead a holy life. The teachings of Confucius, which ignore the existence of God and the immortality of the soul, cannot cleanse the heart or inspire a noble and pure life. The superstitions of Buddhism, leaving its votaries without a guiding Providence in this life, and pointing to extinction as the highest goal of human nature, cannot feed or fill the cravings of the soul for endless happiness. The speculations of Taoism end in its magic and spirit-rapping, and show it to be the doctrine of darkness and devils. From such a review we turn with unspeakable relief to the pure and purifying teachings of Christianity, and cry, with deepest gratitude,-

None but Jesus, NONE bUt Jesus. 


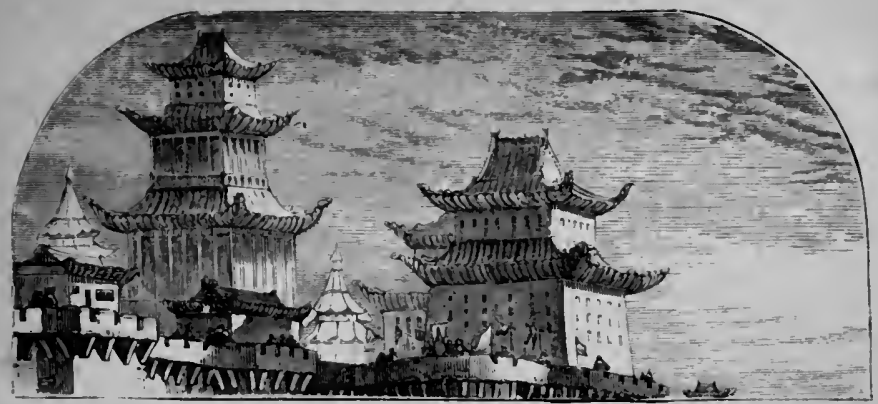

CIHAPTER III.

EARLY ATTEMPTS TO EVANGELISE CHINA.

"Hark! the strains of music roll, Like a tide they fill the soul; As they to their highest rise We will launch our enterprise."

I.YNCH.

ADENT longings for the conversion of China early stirred the souls of consecrated Christian workers, and attempts to diffuse the Gospel throughout the land were made in different periods of the history of the Church. Nor is this to be wondered at. The tenacious life which had prolonged itself during four thousand years, surviving the tempests of time which have carried successive leading empires of the world into utter destruction, stamps the Chinese as being a peculiar people, and invests them with a halo of romance well calculated to fire with enthusiasm the adventurous spirit. Their hoary systems of religion and philosophy, their attainments in various sciences, their proficiency in many arts and manufactures, the immense mineral treasures of the land, have all operated to attract the attention of the student, the merchant, and the statesman. But the enormous population, sunken to 
the lowest moral depths, might well move the benevolent impulses of the philantlhropist, and rouse the zeal of every Christian whose soul vibrates to the command, "Go ye into all the world, and preach the Gospel to every creature."

One insuperable difficulty prevented for centuries Christian effort being put forth for the conversion of the empire of China. The nation has been rootedly and perseveringly opposed to intercourse with foreigners, especially with such as would attempt to proselytise from the accepted religions of the people. Therefore it has hermetically sealed itself at every point against the Christian propagandist. The result was that, up to the commencement of the present century, no evangelical teacher of truth had been able to enter the country ; and, until the middle of the century, no real foothold for the Gospel had been obtained.

It is true that upwards of a thousand years ago an attempt was made to enter China by Christian missionaries. The Nestorians, in the sixth or seventh century, sent out messengers to China; and an interesting relic of their labours remains in a monument at Se-ngan Fu. This monument contains a short history of the Nestorian sect from the year 630 to $78 \mathrm{r}$, and also an abstract of the Christian religion. Scarcely a trace remains of the work done through this movement. When Roman Catholic missionaries entered the country in the fourteenth century they found the Nestorians swaying considerable influence both amongst rich and poor; and it may be reasonably hoped that, through the eight centuries of their history in this land, great numbers of the Chinese were brought under the sanctifying power of the Gospel. The sect eventually lost its simplicity of faith and became extinct, any lingering remnant becoming absorbed in the Romish Church.

During the twelfth century repeated and widespread rumours travelled to the West, in which there may have been some element of reality, concerning Prester John, said 
to have been a great Christian king who ruled over a professedly Christian people in the country contiguous to the north of China. It was rumoured that he united in his person the offices of both king and priest, and that he had successors ruling in a similar manner for some generations.

In the thirteenth and fourteenth centuries there were pioneer messengers from Europe-men of devoted spirit and great capacity, who made their way into China and made known some of the doctrines of the Gospel. The leader of these was a Franciscan monk, John de Monte Corvino, concerning whom the judicious historian, Neander, testifies that he was the pattern of a true missionary. He penetrated to Pekin, and succeeded in gaining a high position in the Court of the Emperor. He became an adept in the language, and translated into Chinese the New 'Testament and the Book of Psalms. With true sagacity he devoted himself to work among the young, and the rearing up of native missionaries, who might disseminate the new doctrine anong their countrymen. He baptised six thousand converts, and founded two churches in Pekin, one of which was so close to the royal palace, that the sweet singing of the Christian hymns was wafted on the morning breeze into the chamber of the Emperor. Corvino overtaxed his strength by his multiplied efforts, so that when fifty-eight years of age he died, prematurely old, and worn out by hardships and privations.

Two and a half centuries rolled by, when a man having a truly apostolic spirit made another attempt to penetrate the great moral desert. In the year 1553 the saintly and lofty Francis Xavier reached the island of Sancian on his way to China. He had passed through gigantic toils in India and Japan, but a hungry dissatisfaction rose within him until he had declared the name of Jesus to the millions of China. Many difficulties arose before him, but he perseveringly strove to overcome them, and he seemed to be on the eve of attaining his desire. From the little islet he strained his 
eyes, and gazed on the rocky beach of the land he yearned to penetrate, and waited impatiently for a junk to carry him over the intervening waters. He meant to land under cover of the darkness of night. He anticipated being seized and cast into prison; but so also were Paul and Silas at Philippi, and a great revival arose out of that persecution. God could still make the wrath of man to praise Him; and if nothing else could be done, some seed could be sown in the hearts of Chinese prisoners which would produce a bounteous harvest when he was laid low. But the All-wise Ruler, who had inspired the idea, and would reward the spirit of devotion, yet did not permit the realisation of the purpose. While he waited for the vessel to take him over the waters he was smitten down with raging fever. He lay upon the beach, with the bleak winds of a bitter winter driving around him. In his delirium his soul seemed to be filled with his apostolic fervour, and he cried out Amplius, amphius, "Wider, further!" As the fever abated .his strength failed, and he lay facing the last dread foe. His face shone with more than earthly radiance, and he wept with holy joy, crying out, "O Lord, in Thee have I trusted, let me never be confounded." Thus triumphantly he passed from the bitterness of an earthly winter to the eternal summer of heaven.

Other kindred spirits soon resolved to attempt again to pierce the great dark heathen continent. The Italian Jesuit Valignano, being stayed at Macao on his way to Japan, beheld afar off the shores of China still closed to the Gospel. He cried, "Oh, rock, rock! when wilt thou open?" and being anxious to carry his aspirations to a practical issue, he induced two of his companions-both men of remarkable character and abilities-to try to storm the impregnable fortress. The attempt succeeded, owing to the united determination and wiliness of the agents. They disguised themselves as Buddhist priests, and then posed as literati of China, with the result that ere long one of them, Mathew 


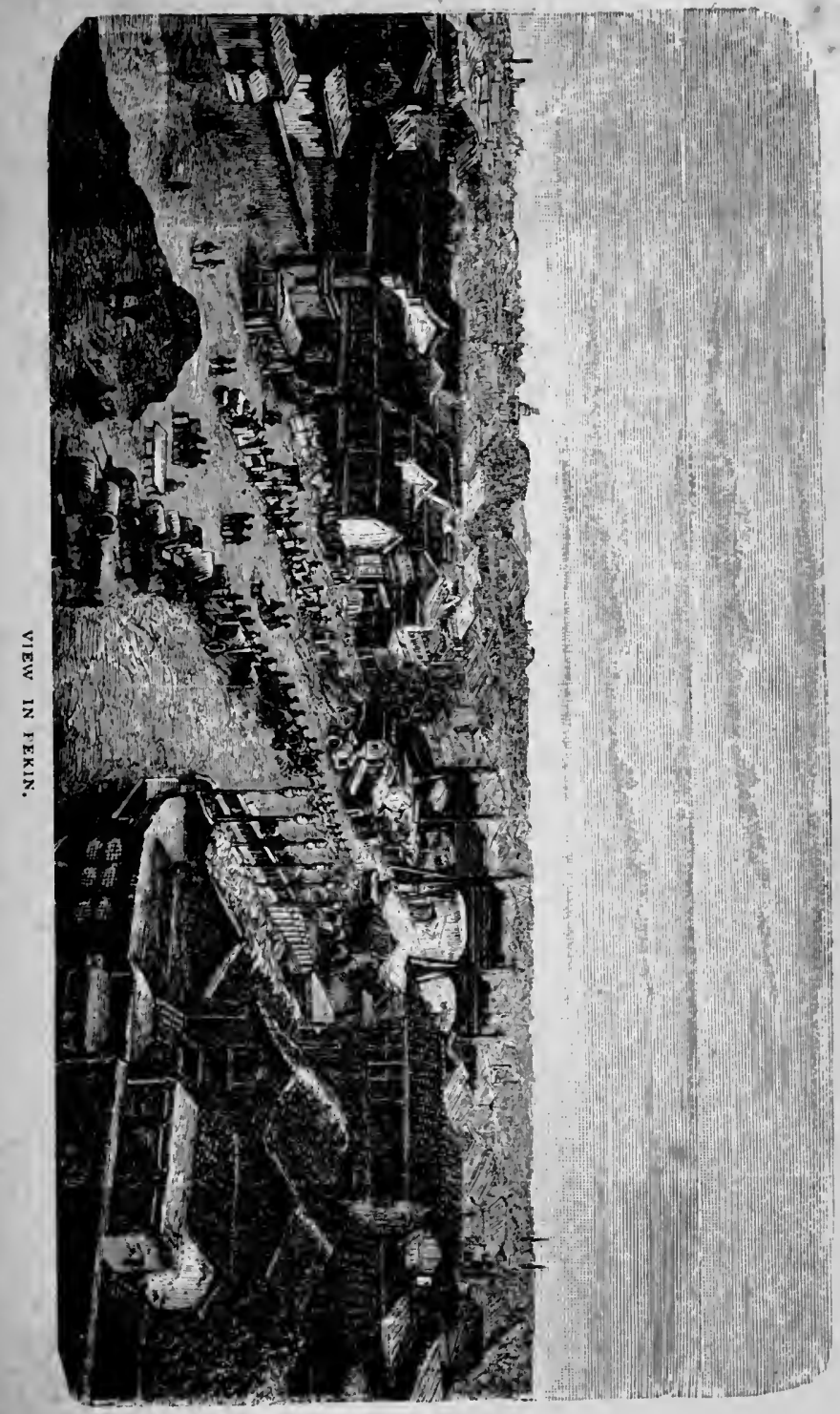


Ricci, was appointed to an important literary post in Pekin, and became a favourite with the Emperor. However otherwise he seemed to be employed, he never failed to labour indefatigably for the establishment and spread of his faith. $\mathrm{He}$ spent twenty-seven years thus, and in 1610 he died, deeply lamented by his fellow-labourers and by the Christian community which had been formed under his guidance. He left upwards of three hundred churches behind him as monuments of his zeal and prudence. He was followed by others of a kindred spirit, men of cautious and sagacious habit of mind, but of fixed purpose. Chief among these were Adam Schaal, who died 1666, and Ferdinand Verbiest, who died 1688 . These were both skilled in science and various knowledges, and, as learned philosophers, had conceded to them an eminence which would have been denied them as Christian propagandists. They arranged the calendar of the year, they directed the casting of cannon, they negotiated treaties with other nations; but through all they kept before them, as their real and sole mission, the diffusion of Christianity. They proclaimed their message in Pekin and the imperial court, they cast their shield over their humbler brethren labouring in various distant provinces and cities, and they contrived to open the gates of the country for the stealthy admission of fresh helpers from time to time.

Persecution broke out, and raged for some years, during which the Christian churches were closed, and the members dispersed; but in $167 \mathrm{I}$, when the tribulation had passed by, and when the existing churches were opened, although further attempts at extension were forbidden, not less than twenty thousand baptisms were reported. It may be that these baptisms were largely nominal, and that the conversion to which they witnessed was only on the surface; it may be that the doctrines disseminated were wofully deficient, from an evangelical standpoint; it may be that the poison of Popery was intermingled with their system, so as largely to discredit their work in our eyes; but let us 
be just to them, and even charitable. The tracts they spread over the land were far superior to the miserable and shallow productions distributed by Roman Catholics of later days, which are largely filled with legendary nonsense. 'They were clear in their statements as to the nature of $\sin$, the incarnation of Christ, and the reality of the atonement. They had many genuine converts, who were ready to seal their faith with their blood; and whatever estimate may be formed as to the character of the work done, let them have the honour paid to their memories, which is their just due, as being the first Christian missionaries to the great centre of heathendom, and as setting an example worthy of imitation to the Reformed Churches. The Roman Catholics have maintained to this day an extensive mission in the land. They have about two hundred churches, and two hundred and fify thousand professors or members. Their interference with the civil and political life of China draws upon them much jealousy and dislike from both the officials and the common people, and but for this they might progress at a much more rapid rate than they have done of late years.

One result of the great evangelical revival of the eighteenth century was the intense desire for the conversion of the heathen which took possession of Protestant Christendom. As a result of that desire, and through the agency of chosen instruments, modern missionary societies arose, and the great evangelistic movement of the present century came into being. It was impossible that, in the urgent yearning to scatter the Gospel amongst the nations still given up to superstition and idolatry, China could be overlooked, or that it should fail to absorb to itself much prayerful attention. Its antiquity, its exclusiveness, its peculiar civilisation, its overwhelming population, made it at once the most interesting, the most difficult, and the most extensive field opened out for conquest by the Church for the Lord Jesus Christ. The Apostles themselves had 
no grander or wider sphere opened before them, as they went out in faith to attack the strongholds of $\sin$ in the Roman empire. The faith, zeal, and unction required by them in their great work were also imperatively demanded of the men who should undertake the task of attacking this hitherto invulnerable fastness of $\sin$.

To briefly trace the career of the first modern apostle to China, who, with indomitable and persevering zeal, went forth to this giant enterprise, is the object of these pages ; and it is earnestly hoped that the narration of this story will fire many hearts with a generous and Divine enthusiasm in aid of the great work for the conversion of this enormous nation. The motto of every Christian just now should be-

China for Christ, and in this Generation.

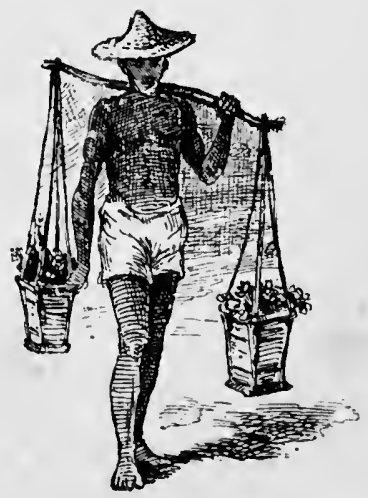




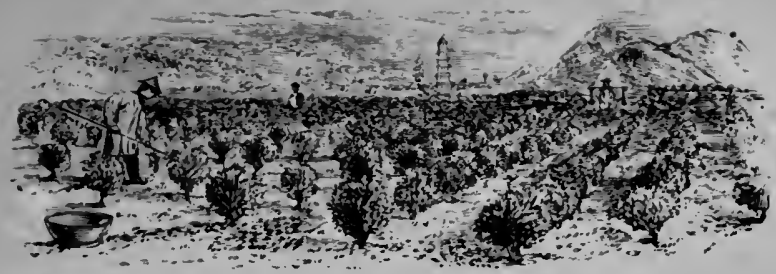

CIAPTER IV.

ROBERT MORRISON : CHILDHOOD AND YOUIH.

"Fair boy, the wanderings of thy way

It is not mine to trace,

Through buoyant youth's exulting day,

Or manhood's nobler race.

"What discipline thine heart may necd,

What clouds may veil thy sun,

The eye of God alone can read,

And let His will be donc."

$\mathrm{R}^{\mathrm{o}}$

OBER'T MORRISON was born on January 5 th, 1782 , at Buller's (ireen,* in the little picturesque town of Morpeth, Northumberland. His father, James Morrison, was a farm labourer, who removed, when Robert was three years old, to Newcastle-upon-Tyne, where he established a busmess as a last and boot-tree manufacturer in the (iroat Market. 'The place where he and his family resided was long called by the name of "Morrison's Close," in remembrance of his famous son. Here he employed several workmen, earned a comfortable livelihood, and brought up his family of eight children in the fear of God.

He was a Scotchman by birth, his wife was a Northum-

* The louse was in existence till Marcl $2 \mathrm{Sth}, 1 \mathrm{SS} 7$, when it was razed to the ground. 
brian, and both of them were people of fervent and consistent piety. They became members of an old Presbyterian church in the High Bridge, the entrance to which was through a public-house yard. Mr. Morrison was held in high estimation by the church, and an old lady, who knew him and his son Robert well, and who was a member of the same church, recently testified that the father was a most worthy man, and that no member or officer of the church was so highly esteemed. $\mathrm{He}$ was for many years a much valued elder of the church. The minister at that time was the Rev. John Hutton, a man faithfully devoted to the interests of his people, and one who exercised a healthful and powerful influence on the mind of the subject of this memoir.

Robert was sent to a school kept by James Nicholson, his maternal uncle-a man of respectable attainments. Here he received a sound elementary education. For some time he showed great slowness in learning, and has been ranked amongst the illustrious dunces of history ; but afterwards he brightened up, manifested great delight in his studies, and made rapid and satisfactory progress.

He was also carefully trained in Scripture knowledge and religious duties by his pastor, Mr. Hutton, who frequently catechised him, both at home and in public, after the fashion long in vogue in Scotland and in the North of England. The story is a favourite tradition in Newcastle, and used often to be told by the old lady already referred to, that when he was twelve years of age, he repeated in the chapel one Sabbath evening the whole of the IIgth Psalm; and, to further test his memory, the pastor exercised him on different parts in various ways, the boy passing through the ordeal without a single error.

On leaving school at the age of fourteen, he was bound apprentice to his father, and wrought at his trade with great diligence and industry. For a brief period he seems to have been led into evil courses by careless companions, but at 
home he manifested such dutifulness that his father rarely had need to utter a word of rebuke. Towards his mother he showed a loving attention that was almost chivalrous; and he had so keen a love of truth that never but once was he ever known to tell a falsehood, and then, although he had no fear of detection, he felt such qualms of conscience that he made an open confession of his fault. In 1798 he relinquished his bad liabits, separated himself from all friends that were evil or doubtful, and became soundly converted to the service of God. The great change seems rather to have been the outcome of long previous training, and of healthful religious influences around him, than of any special instrumentality; but he at once sought union with the church, and joined a meeting for prayer which assembled in his father's workshop on Monday evenings. He also began a course of devotional reading, chiefly of the Scrip:ures; drew out a plan for the regulation of his time, which he carcfully observed; and even learnt a system of shorthand to facilitate his studies. He formed an intimacy with a young man at Shields of kindred religious fervour, and they met almost daily for prayer and pious conversation. They also visited together the sick poor, and engaged in work for God in various ways as they had opportunity.

Gradually his soul became more deeply engrossed with religious subjects. In 1800 he removed his bed into the workshop for the sake of greater privacy, and often till one or two o'clock in the morning was engaged reading Romaine's "Life of Faith," or Hervey's "Meditations," or Marshall on "Sanctification," or Mosheim's " History of the Church," but most of all searching the treasures of Matthew Henry's incomparable "Commentary." He also strove to perfect himself in English granmar, and carefully examined the evidences of Christianity. The Missionary Magasine had begun to appear from an Edinburgh publisher, and this he borrowed regularly from a friend ; and probably from this periodical he received the first bias of his mind towards the 
mission field. 'The workshop where he studied and slept remained till lately in much the same condition as when he left it. In ${ }^{2} 8_{59}$ a rude attack was made in Newcastle-uponTyne upon the memory of Dr. Morrison, by Rev. R. I. Wilberforce, then a Romish pervert. This was taken up and replied to in a lecture by Rev. J. C. Bruce, D.D., from which we extract the following passage :-

"'The shop is at present occupied by a joiner. I visited the room last week in company with my friend, Mr. John Fenwick. The place is in a somewhat frail state, and its whole aspect is such as rather to depress than to excite any noble elevation of soul. My friend, on entering, felt himself carried back fifty years. He pointed to the bench where he had scores of times seen Morrison at his work, and told me that he generally found him with a book lying open before him. In this humble workshop two of Northumberland's greatest men must frequently have met-Robert Morrison and George Stephenson. The families of each were mutually acquainted. Mr. Stephenson, when a young man, filled up his spare time with making shoes. He made his own lasts, and boasted of his performances in this way. On one occasion Stephenson entered into competition with a fellow-artist, and, in order to exclude the possibility of prejudice on the part of the umpire, obtained leave from the Morrisons to affix their stamp to his production."

Young Morrison also rented a little garden in Pandon Dene, then a charming suburb of Newcastle, but which has now disappeared before the march of building and commerce. Here he often repaired for quiet meditation and prayer; and, even when at work, the Bible or some other book was open before him, in order that his heart and mind might be refreshed while his hands were busily occupied. On the Sabbath he regularly attended the services of the church, he often conducted family worship in his father's house, he regularly visited the sick and devoted a proportion of his scanty earnings to their relief, and the intervals between 


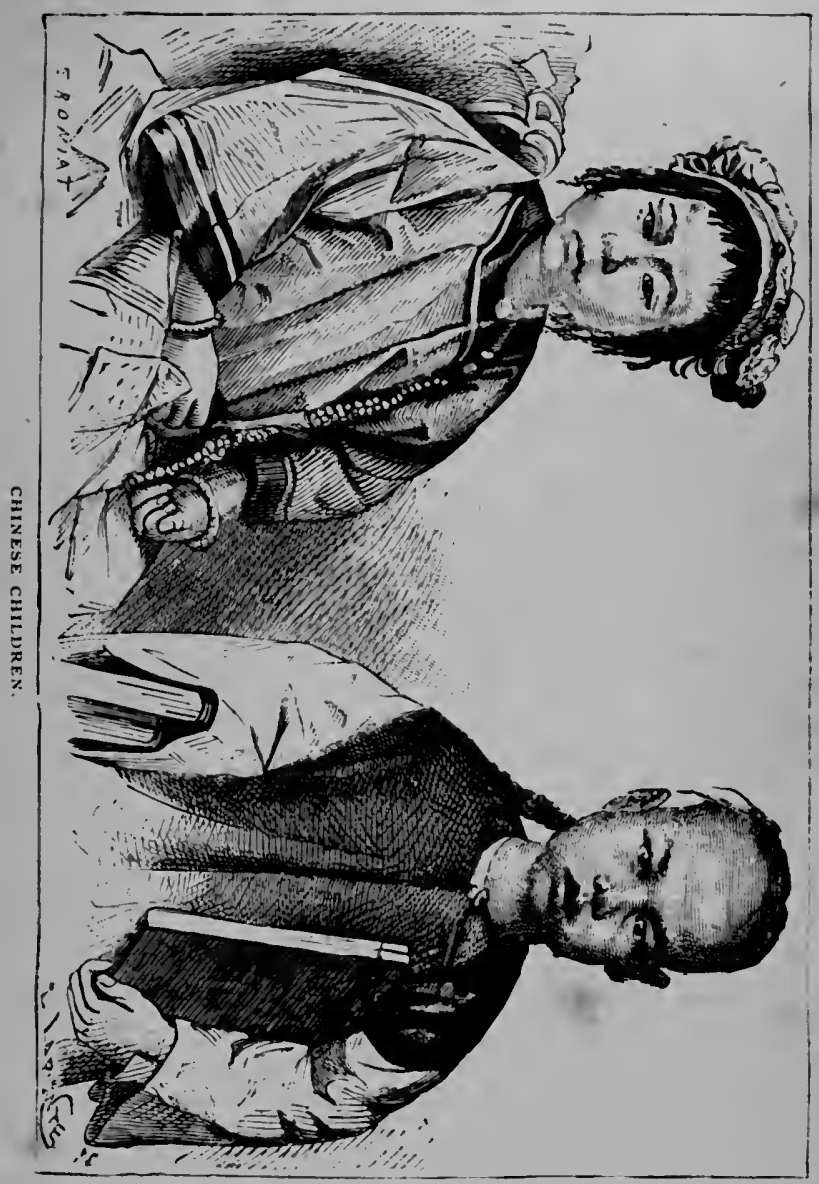


worship on the Sabbath he generally gave to the instruction of poor children. His father had a young apprentice whom he strove to win for Christ, and he often took him aside to pray with him privately. His soul became intently earnest in seeking the conversion of his kindred and friends. He appealed to one young relative-a sailor-with such pertinacity, imploring him to seek the Lord, that the young man said his words were never out of his ears, until he was led to come to Jesus. Thus from his earliest Christian life he manifested those profound convictions of duty, that intensity and fixedness of purpose, and that desire for the salvation of souls, which characterised all his future course.

His early Christian life is very interestingly described in a letter he wrote to the Committee of Hoxton Academy, when, in 1802 , he offered himself for the work of the ministry. In it he states as follows :-

"In the early part of my life, having enjoyed the inestimable privilege of godly parents (a blessing for which I ever desire to be thankful), I was habituated to a constant and regular attendance on the preached Gospel. My father was ever careful to kecp up the worship of God in our family, and educated me in the principles of the Christian religion. When farther advanced in life, I attended the public catechising of the Rev. John Hutton, from whose instructions I received much advantage. By these nieans (under the good hand of God) my conscience was somewhat informed and enlightened, and I was kept from running to that excess of riot to which many persons in an unregenerate state do, though as yet I lived without Christ, without God, and without hope in the world. I was a stranger to the plague of my own heart; and, notwithstanding that I often felt remorse and the upbraidings of conscience, yet I flattered myself that somehow I should have peace, though I walked in the ways of my own heart.

"It was about five years ago that I was much awakened 
to a sense of sin, though I cannot recollect any particular circumstances that led to it, unless it was that at that time I grew somewhat loose and profane, and more than once, being drawn aside by wicked company (even at that early time of life), I became intoxicated. Reflection upon my conduct became a source of much uneasiness to me, and I was brought to a serious concern about my soul. I felt the dread of eternal condemnation. The fear of death compassed me about, and I was led to cry nightly to God that $\mathrm{He}$ would pardon my sin, that $\mathrm{He}$ would grant me an interest in the Saviour, and that He would renew me in the spirit of my mind. Sin became a burden. It was then that I experienced a change of life, and, I trust, a change of heart too. I broke off from my former careless company, and gave myself to reading, to meditation, and to prayer. It pleased God to reveal His Son in me, and at that time I experienced much of 'the kindness of youth and the love of espousals;' and, though the first flash of affection wore off, I trust my love to and knowledge of the Saviour have increased. Since that time (soon after I joined in communion with the Church under the Rev. John Hutton, my present pastor, and likewise became a member of a praying society) the Lord has been graciously pleased to humb?e and prove me ; and, though I have often experienced much joy and peace in believing, I have likewise experienced much opposition from the working of indwelling sin-' the flesh lusting against the spirit, and the spirit against the flesh'-and these being contrary the one to the other, 'I could not do the thing that I would.' I have gradually discovered more of the holiness, spirituality, and extent of the Divine law, and more of my own vileness and unworthiness in the sight of God, and the freeness and richness of sovereign grace. I have sinned as I could; it is 'by the grace of God I am what I am.' "

For some years he kept a diary, or journal, in which he recorded his doings and experiences. The entries reveal, 
in a natural and easy manner, the real bent of his mind. Two or three extracts from that kept in 1800 may he given as a specimen of many :-

"February 5 th.-Rose at five. Text, Nahum i. 7 : "The Lord is good, a stronghold in the day of trouble, and $\mathrm{He}$ knoweth them that trust in Him.' Comfortable words! In the evening I took a walk, and was delighted with the works of God. The sun descending, the moon shining brightly, the night was come, and the ocean murmured at a distance. God is my Maker and my Saviour. 'I his night I was alone in the house, when I engaged in prayer to my God. Slept five hours."

"February 23rd.-Sunday. Kose at half-past six. Went and took a walk to the Forth, very misty. Came home and went to prayer in the shop. O blessed solitude, I love thee! I am not alone, for God is with me. Read a part of Mr. Romaine's sermon on the death of Mr. Hervey. Went to the meeting-house, and heard a lecture on 'Simon Magus.' After dinner I took Jem into the shop and prayed with him, and then asked him his catechism. In the afternoon I heard a sermon on 'Christ Crucified.' I took my tea with my brother 'Thomas. C. H. and I joined in singing, prayer, and reading the Scriptures. Text, Psalm xlviii. I 4. I was beset with vain thoughts, and 'when I would do good, evil is present with me."

"June 18th.-Rose at five. After prayer I sat till six, then went to work, and wrought till nearly 8 P.M., when C. H. came up. We joined in singing, prayer, and reading a sermon, after which I took a walk as far as the garden with him. We called on Mr. Hutton. We were engaged in serious conversation. Oh that I may watch and be sober when my Lord cometh!"

In $180 \mathrm{I}$ he began to entertain definite ideas as to entering the Christian ministry, and prepared to study systematically with this object before him. 'The following passage from his diary indicates his state of feeling at this time :- 
"Friday, June I 9 th.-This day I entered with Mr. Laidler* to learn Latin. I paid ten shillings and sixpence (the entrance money), and am to pay one guinea per quarter. I know not what may be the end-God only knows. It is my desire, if He please to spare me in the world, to serve the Gospel of Christ as $\mathrm{He}$ shall give me opportunity. O Lord, my God, my whole hope is in Thee, and in Thee alone. God be merciful to me a sinner through Christ my Saviour, and grant Thy blessing with this attempt, if it please Thee. Amen."

This extract plainly shows the direction of his thoughts, and he arranged all his novements accordingly. $\mathrm{He}$ wrought at his trade from six to six, save that from nine to ten he waited on Mr. Laidler. He arranged his meals so as to facilitate his studies, and nightly he was at work with his books when the rest of the household had retired to sleep. So assiduously did he cultivate knowledge that, eighteen months afterwards, when he entered Hoxton Academy as a student, he had not only a fair knowledge of Latin, but had also acquired the rudiments of Greek and Hebrew.

While he was thus earnestly devoting himself to preparations for future advancement, he went for a short time to Sunderland to gain a knowledge of another branch of his father's business, and there became acquainted with a young man called Wilson. This friend relates the following incident:-

"Four or five of us very young men were conversing together about some of those things which the hoaryheaded Christian places among the secret things of God, and which he adores in silent submission. As Mr. Morrison was not forward in speaking, we requested him to favour us with his mind on the subject before us. He replied, 'Whatsoever I may not know of these things, this I do know, that I am a sinner, and that Jesus Christ is a suitable Saviour.'

* A minister resident in Newcastle. 
Such a remark from the youngest in the company forcibly struck us all."

Between Robert and his mother there existed a most tender affection. He was her favourite son, and with true maternal instinct she soon guessed the bent his mind was taking towards the ministry of the Church. But, as infirmities increased upon her, she clung passionately to him, and was distressed at the idea of him leaving home. His sense of filial obedience was so strong that he promised he would never do so as long as she lived. Such was her confidence in him, that she looked to him for comfort and solace in the later experiences of her life. In 1802 she was taken from her family and from earth by death. During her illness he assiduously attended her bedside, marking her wants, giving her medicine, offering prayer by her side, and finally, after receiving her last blessing, closing her eyes in death.

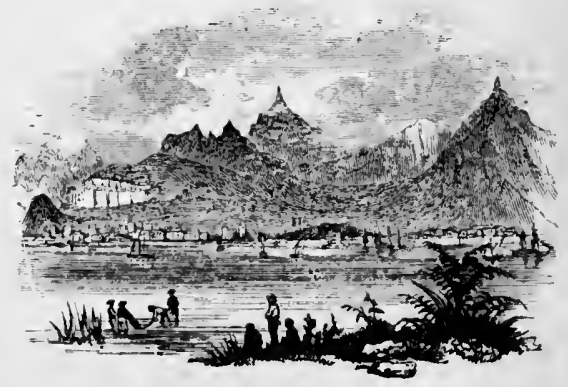




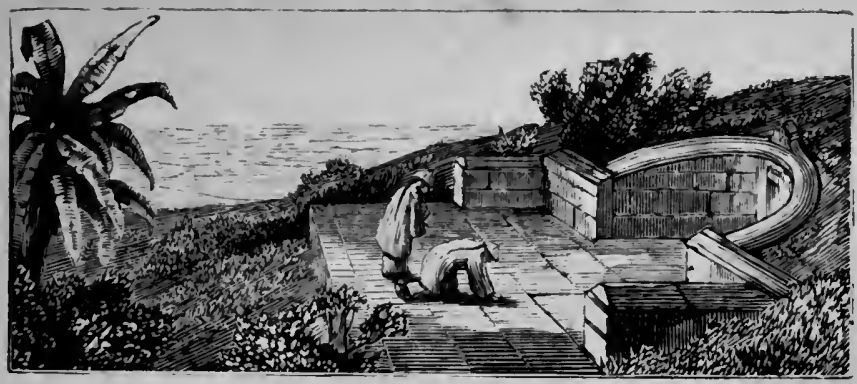

\section{CHAPTER V.}

\section{PREPARATION FOR THE GREAT WORK.}

"Great offices will have

Great talents, and God gives to every man

The virtues, temper, understanding, taste,

That lifts him into life and lets him fall

Just in the niche he was designed to fill."

Cowper.

$A^{\mathrm{S}}$

S Mr. Morrison laboured diligently in his preparations, his purpose became more definite and settled. The way into the ministry of the Presbyterian Church did not open, and his thoughts were directed to the Congregational Theological Institution, then known as Hoxton Academy, afterwards as Highbury College. The two following extracts indicate the yearning of his soul both as to progress in the Divine life, and a ministerial course :-

"O blessed Jesus, long have I sought for rest to my immortal soul, at one time in the gratification of 'the lusts of the flesh,' and at another 'of the mind.' When very young I was a companion of the drunkard, the Sabbathbreaker, the profane person; but in these my heart smote me, I had no rest. Then I made learning and books my god; but all, all are vain. I come to 'Thee: 'Come unto $\mathrm{Me}$, all ye that labour and are heavy laden, and I will give 
you rest.' Fatigued with unsuccessful pursuits after happiness, and burdened with a sense of guilt, Jesus, Thou Son of God, I come to Thee, that I may be refreshed and my burden removed.

\section{"' Jesus, my Lord! Thou art possest Of all that fills the eternal God! Oh! bring my weary soul to rest, Remove my guilt, that ponderous load.'"}

On September $25^{\text {th }}$, 1802, he wrote thus :-

"This day I wrote to - desiring to know some things respecting the Hoxton Academy. What shall I say on this day now closing? O Lord, pardon my sins, and make me Thine in that day when Thou makest up Thy jewels; in 'that day when God shall judge the secrets of men by Jesus Christ.' 'Have faith in Jehovah with thy whole $m$ nd: but lean not to thy own understanding. In all thy ways acknowledge Him, and He will direct thy paths.' 'Thou shalt love the Lord thy God with all thy heart, and with all thy mind, and with all thy thought. This is the first and great commandment.'"

On November $24^{\text {th }}$ he made formal application for admission to the Academy. His letter deals at great length with his early religious impressions and his conversion to God, and then proceeds in the following sentences to refer to his doctrinal sentiments and his call to the ministry:-

"As the compass of one letter will not suffer me to enlarge with respect to my principles, it will perhaps be sufficient to observe that, being educated in the doctrines of the Church of Scotland, as contained in the Westminster Confession of Faith; so far as I have been enabled to examine them as yet, I have espoused them from principle. Hence also my views with respect to the ordinance of baptism will be known.

"As to the motives that induce me to wish to be a 
minister, they are these-viz., an earnest desire of being instrumental (under the good hand of God) in turning sinners from darkness to light, and from the power of Satan unto God-of being instrumental in building up the Church -being zealous of spiritual gifts, I seek that I may excel to the edifying of the Church. I covet to prophesy, for he that prophesieth speaketh to men to edification, to exhortation, and to comfort; and I would moreover observe that these passages not only express my motives, but also contain what I considered a warrant for my present undertaking, as they come from the apostle to the Church of Corinth in the form of an exhortation, 'Seek that ye may excel.' 'Covet to prophesy.'

"However, I would willingly resign myself to the direction of my heavenly Father. He knows best, and will choose and use what instruments $\mathrm{He}$ seeth meet. His will be done."

He was inmediately accepted by the Committee and summoned to London, where he arrived on January $6 \mathrm{th}$, 1803 .

Hoxton Academy was then under the care of the Revs. Dr. Simpson and WT. Atkinson, and amongst the students he found congenial spirits in men known afterwards as Revs. H. F. Burder, D.D., of Hackney ; J. Clunie, LI.I)., of Manchester; J. Fletcher, D.I)., of Stepney; and G. Payne, LI..I)., of Exeter; with all of whom he maintained a firm friendship, and with the two former a close intimacy until his death.

He had scarcely settled at the College before a trial came which deeply moved his spirit. His father's health had been feeble for some time, and the business had been largely dependent on the exertions of Robert. His father grew worse, and an urgent and affectionate summons came for his son to return home and resume his former position. His heart was too fixed and his enthusiasm for his new calling too imperative to permit him to do so, and he wrote 
a reply which, whilst brimming with tenderness and filial piety, yet expressed his unalterable purpose to pursue his sacred calling.

\section{"February $5^{\text {th }}, \mathrm{1} 803$.}

"Honoured father, brother, and sisters,-I received your letter on the I 1 th ult. 'The account of my father's leg growing worse and worse concerns me; but what can I do? I look to my God and my father's God. ' $\mathrm{He}$ doeth all things well,' and He will make all things work together for good to those that love Him. My father, my brother, my sisters, I resign you all and myself to $H$ is care, who I trust careth for us. Are not our days few ? Yet I desire, if the Lord will, that $\mathrm{He}$ may grant you wherewithal to provide things honest in the sight of all men during the few days of your pilgrimage. I trust $\mathrm{He}$ will ; and may the Lord bless you with rich communications of saving grace and knowledge. You advise me to return home. I thank you for your kind intentions; may the Lord bless you for them. But I have no inclination to do so; having set my hand to the plough, I would not look back. It hath pleased the Lord to prosper me so far, and grant me favour in the eyes of this people."

His family were still not satisfied with his decision, and it was a painful subject for him to write about; but he never swerved for a moment from what he firmly believed to be a sacred duty, and both his father and brother and sisters lived long enough to recognise that he had been led by Divine Providence in his chosen path.

He had not been long in the Metropolis before he presented himself to the Rev. Dr. Waugh, a minister of fervent piety and affectionate spirit, who then presided over a large church in Wells Street, Oxford Street. He was received into membership, and shortly afterwards preached his first sermon in St. Luke's Workhouse, and from that time he became a frequent preacher in the villages around I.ondon. He also found many opportunities to visit 


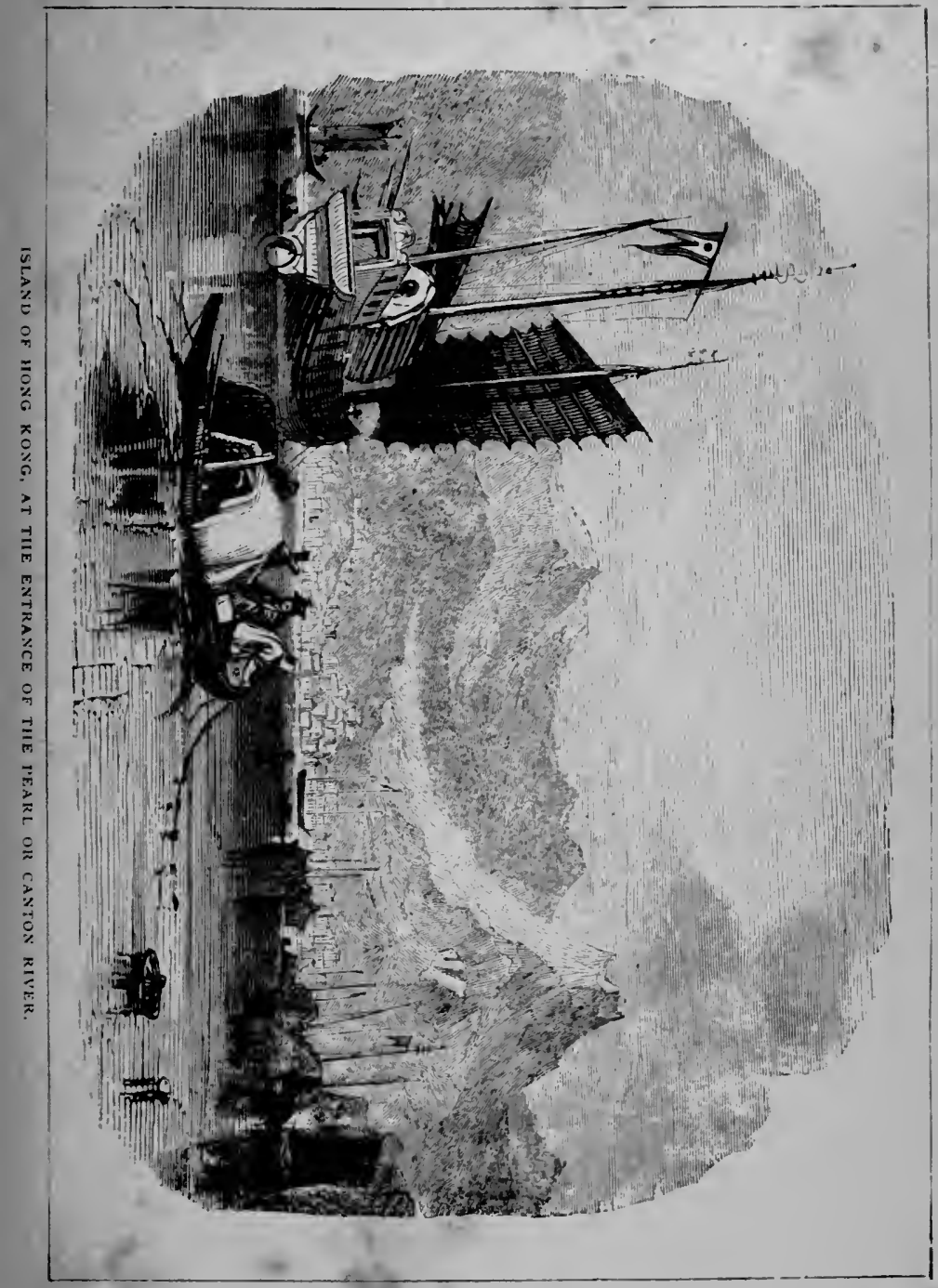


the poor and sick, after the habit he had formed at Newcastle.

He pursued his studies at Hoxton with untiring assiduity, and his fellow-students above referred to have left glowing testimonies as to his fervid pursuit both of mental and spiritual attainments. Dr. Clunie sums up a very full description of his college life in these words: "He was a most exemplary student, and always aimed at distinction, even in some branches of study for which he appeared very little adapted. But his chief reliance to secure success was not on any effort of his own, however diligently and constantly exerted, but on the Divine blessing. Hence few ever entered more fully into Luther's great axiom, 'To pray well is to study well ;' for of him it may be very justly said, that prayer was the element in which his soul delighted to breathe. Though it was little apprehended that he would so soon be called to fill one of the most arduous and important spheres which could be conceived, or that he would rise to such eminence in it as to command the admiration of all classes of the Christian Church and of the community in general, yet it is impossible to reflect on his diligent and deroted course at Hoxton without clearly recognising the incipient elements of all his future success. Others possessed more brilliant talents, a richer imagination, a more attractive delivery, or more graceful manners,-but I trust I may be permitted to say that there was no one who more happily concentrated in himself the three elements of moral greatness, - the most ardent piety, indefatigalsle diligence, and devoted zeal in the best of all causes."

After he had been a short time at college a desire for foreign missionary work, which had occasionally arisen within him at home, became a definite and ruling purpose of his soul. He made this known to the tutors and treasurer of the institution. 'They represented to him the arduous nature of the work, and the special opportunities he had 
for great usefulness in the home field, and offered him the privilege of a training at one of the Scotch universities. They advised him to carefully pray and think about the matter. This advice he readily adopted, with the result that his purpose became greatly strengthened; and on

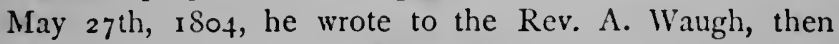
chairman of the Committee of Examination of the London Missionary Society, offering himself for labour in a foreign sphere. His letter has been often referred to as a model one. It briefly records the facts of his conversion, of his desire to enter the ministry, and of his growing interest in mission work. He says :-

"My first wish was to engage as a Missionary. This was the burden of my prayer. I avowed this design to my friends. I frankly own it was the wish of my heart when I came to Hoxton; and had the question been asked of me I should have professed it. I had no design to conceal it ; but I then considered ingsclf unfit, and believed learning necessary. I knew nothing of a Missionary Academy. I still cherished the desire of being a Missionary, but thought it premature to eome to a determination, and therefore entered upon the foundation at Hoxton. Knowing that 'Jesus wills that His Gospel should be preached in all the world,' and that 'the redecmed of the Lold' are 'to be gathered out of every kindred and tongue and people'; recollecting, moreover, the command of Jesus to 'go into all the world, and preach the Gospel to every creature,' I conceive it my duty, as a candidate for the Holy Ministry, to stand candidate for a station where labourers are most wanted. My affectionate relatives in the country, and my kind friends and patrons in town dissuade me from it, tell me of the difficulties I shall have to encounter, and promise me much should I stay at home. I have considered these things, prayed to the Lord to direct me and to enable me to count the cost, that I may not act the part of a foolish builder. I am extremely suspicious of my'self, jealous of 
the strength of my love to Jesus to bear me through. But leaning on His love to me, I have now, sir, made up my mind, if the Lord will, to 'forsake all and follow Him,' to spend and be spent for the elect's sake, that they may obtain the salvation which is in Christ Jesus, with eternal glory."

In coming to this decision he had a painful struggle with his home relatives, who were strongly opposed to it. $\mathrm{He}$ pleaded the case most tenderly and affectionately with his father, offering to desist from his purpose, "If my father or other friends can give such reasons why I should not take this step as will satisfy my mind on a dying bed." No such reasons were forthcoming; but the struggle of mind he endured may be imagined from these words, extracted from a letter he addressed to his very intimate companion Cuthbert Henderson: "My brother Thomas has sent a letter which grieves me very much. $\mathrm{He}$ represents the situation of my father's affairs in such a distressing light . . and then charges me with wilfulness that I can help them, and won't. Shall I see my father's house thus thrown into confusion? I myself, my dear brother, wander from day to day, mourning an absent Lord. I wander under the hidings of my Father's countenance, under a sense of my own ignorance and weakness. What can I do? For years past I have desired and prayed and laboured night and day for that which the Lord has been pleased to bring about; and now when my wishes are gratified, my prayers are answered, shall I turn back? O my God, I lift my soul to Thee. How shall I stand before Jesus in the day of judgment, should I now forsake Him and His work when a difficulty arises? $\mathrm{O}$ my friend, pray that the Lord may remove all my sins, that $\mathrm{He}$ may make my way plain before me, that He may be near to my precious and immortal soul; pray for my brother and father, I entreat thee, my good friend-go often to see them; and may the Lord bless thee and keep thee through faith unto eternal salvation." 
On Monday, May 28 th, he appeared before the Missionary Board. The interview was so satisfactory that the usual custom of a second examination was dispensed with. $\mathrm{He}$ was accepted at once, and ordered to proceed to the Missionary Academy at Gosport, then presided over by the venerable Dr. Bogue.

He prepared to obey the order at once. His fellowstudents affectionately commended him to "the special grace of God," in a meeting for united prayer; and on the Wednesday following his acceptance, he proceeded to Gosport, where he received a warm welcome from the Governor of the Institution. His stay there was but a short one, his fitness and preparedness for the work being soon demonstrated; and arrangements were quickly made for his appointment to a sphere of labour. For some time he was in uncertainty as to his destination, and writing to his friend Mr. Clunie, on July 3 ist, he says :-

"My future destination is altogether unknown to me. It is in agitation to send a mission to China. Mr. Bogue seems quite fond of it. I have had some thoughts of going into the interior of Africa, to Timbuctoo. I give up my concerns to the Lord. I hope $\mathrm{He}$ will open a door of useful missionary labour in some part of the world, and give me souls for my hire."

At the same time also he wrote to his sister Hannah: "It is in agitation to send me on a mission to China; however, it is altogether uncertain as yet. I have thought of going to Timbuctoo, in Africa. I hope the Lord will carry me out to some situation where $\mathrm{He}$ will make me abundantly useful to the souls of men."

The references to 'Timbuctoo may be explained by the fact that the brave but unfortunate traveller, Mungo Park, was at this time contemplating the formation of an English settlement there. It was in deliberation to send a medical gentleman, Mr. Anderson, to Africa, and a clerical missionary with him. Mr. Morrison seems to have been anxious to 
go; but the Committee of the Society designed him for other work, and at first were disposed to send him to Prince of Wales' Island, in the Malacca Straits.

He was not left long in uncertainty as to his destination, but was appointed to China, and directed to turn his attention to gaining an elementary knowledge of the Chinese language, with the object of qualifying himself to translate the Bible into that tongue. Mr. Morrison ever firmly believed that the appointment to China was providential. He had made his appointment a matter of special and prolonged prayer, and had even pourcd out a supplication that for lofty self-forgetfulness was truly apostolic-viz., "That God would station him in that part of the missionary field where the difficulties were the greatest, and, to all human appearance, the most insurnountable." The sequel seems to show that this prayer was certainly answered.

The idea which was in the mind of the Committec in making the appointment, was that the agent selected should proceed to China, either seeking a residence in the country itself, or finding a refuge on one of the adjacent islands, and should there obtain a knowledge of the language, and proceed with a translation of the Bible. More than this was not contemplated just then; when it was accomplished, the next step was to be considered.

The design of the Committee also included the appointment of two or three others to accompany Mr. Morrison; and a son of the celebrated Rev. Dr. John Brown, of Haddington, was actually selected, but he declined the invitation. Then Dr. Vanderkemp was requested to leave Africa, and proceed to China to superintend the mission. This also came to nothing. Evidently Providence was directing the movements of the Society by unrecognisable means. As we look backwards from our standpoint to-day, it seems quite evident that if a company of agents had gone to China, they would have drawn towards themselves the virulent opposition of the ruling powers, and rendered all 
efforts to obtain an introduction for the Gospel unavailing. The appointment of Mr. Morrison therefore remained, no companion being found to share with him the trials and responsibilities of the enterprise.

In August 1805 he left Gosport, and proceeded to London, that he might gain some useful knowledge in astronomy and medicine, and also that he might gather up as much knowledge of the Chinese language as was there practicable. He walked St. Bartholomew's Hospital, and attended a course of lectures on medicine given by Dr. Blair. He went to Greenwich, and studied astronomy under Dr. Hutton. He resided in Bishopsgate Street, and walked to and from Greenwich, carrying his various mathematical and other instruments, and reading the whole of the way. He also engaged the services of a Chinese teacher then residing in London, called Yang-Sam-Tak. 'This man was possessed of some learning, but was of a most impetuous, passionate, and proud spirit. Mr. Morrison was greatly tried by his fierce and domineering temper; but he bore with him with marvellous patience, for the sake of attaining his great object, and also for the sake of the man himself, whose spiritual welfare he greatly coveted. On one occasion Mr. Morrison burnt a piece of paper on which Sam had written some characters. He had committed them to memory, and had no more use for them; but such was his teacher's indignation, that for three days he refused to continue his instructions; and to avoid similar offence, his pupil afterwards wrote on a piece of tin, from which he could rub out the characters when they were no longer needed. It is gratifying to know that Sam was so far won by the kindness and patience of his pupil, as to join him in reading the Scriptures, and also to unite in the worship of the household-a thing he had previously regarded with scorn. In after life he obtained, through Mr. Morrison's influence, an excellent situation in the warchouse of a merchant at Hong Kong. 
In the British Museum a manuscript had been discovered by the Rev. W. Moseley, Congregational minister of Long Buckby, Northamptonshire, which contained the principal portion of the New Testament translated into the Chinese language. It was a folio volume, and by mistake had been lettered, Evangelia Quatuor Sinice. On a blank leaf at the beginning of the volume is this note: "This transcript was made at Canton in 1737 and 1738 , by order of Mr. Hodgson, who says it has been collated with great care, and found very correct. Given to him by Sir Hans Sloane, Bart., in 1739." Mr. Moseley was incited by this discovery to publish a treatise on "the importance and practicability of translating and publishing the Holy Scriptures in the Chinese language." After Mr. Morrison had acquired some familiarity with Chinese characters, he commenced to transcribe this MS., and also a MS. Latin and Chinese Dictionary, which was possessed and lent to him by the Royal Society. By extraordinary application, he copied these MSS. in the few months of his residence in London, besides pursuing with ardour the other studies previously mentioned, and engaging in many works of practical benevolence. Speaking of these endeavours to prepare himself for his work, Dr. Milne says: "What was acquired of the language proved afterwards of trifling utility. The Dictionary and the Harmony of the Gospels were more useful. These were originally the work of some of the Romish missionaries in China. By what individuals, or at what time, these works were compiled, has not been ascertained; but Providence has preserved them to be useful, and the just merit of their authors will doubtless one day be reckoned to them."

During this period of preparation his mind was deeply concerned for the salvation of his brothers and sisters, and their children. He wrote many letters to them, overflowing with affection and desire for their welfare. He paid a farewell visit to them in July. His friends gathered round him. 
and manifested such attachment to him as greatly to try his resolution, although without in any degree shaking it. $\mathrm{He}$ spent a fortnight amongst them, preaching thirteen times, and visiting all his friends and acquaintances, going down also to Edinburgh and Glasgow. Then he returned to London, and prepared for his departure. On October 23 rd he wrote to his father: "I met the Directors on Tuesday last, when it was agreed by the Committee that I should proceed by the first conveyance to Madras, thence pass on to Malacca, there leave my luggage, and pay a visit to Canton, to see whether or not I can settle there. If I can, I will send to Malacca for my books; and if not, I shall return and take up my residence at Malacca, where there are a few thousands of Chinese, and where I shall endeavour to learn the language, and also, as soon as I can, preach the Gospel to the Malays."

Again, on December 23 rd, he wrote to his brother Thomas: "I hoped when I wrote to you last that ere this time I should have been on my way to China. It was fully the intention of our friends that it should have been sn; but, owing to the indisposition of Messrs. Hardcastle and Cowie, the necessary steps were delayed. You must understand that none of our missionaries can go out to India in an English vessel, without the express leave of the-East India Company. Their leave was solicited for the Baptist missionaries, who are now at Serampore, near Calcutta, and they refused it. Our missionaries who are now in India went out in foreign neutral vessels. Our Society never asked their leave, but now think of doing it for me."

The permission, however, could not be obtained. A passage was secured for him and two fellow-studentsMessrs. Gordon and Lee, who, with their wives, were about to proceed to other portions of the mission field-in the good ship Remittance to New York, whence he would proceed to Canton direct or by way of India, as might seem most fitting on his arrival in America. 
His feelings at the near prospect of bidding farewell to home and fatherland may be judged by the following words from his journal under date January 2nd, 1807 :-

"This is one of the most important periods of my life. O Lord! 'except Thy presence go with me, carry me not up hence.' May the blessing of God Almighty accompany me. May the angel of His presence go before me. I feel not much cast down. I endeavoured this evening to recollect some of the promises on which I hope. "Fear not, for I am with thee,' came into my mind ; and again, 'Fear not, thou worm Jacob.' I hope to be enabled to lean always and only on the arm of God; none else can hold me up."

He was ordained and consecrated to his sacred and apostolic work on January 8th, 1807 , in the Scotch Church, Swallow Street, in company with the two missionaries above named. Prayer, reading of the Scriptures, and exhortation were conducted by the Rev. T. Townsend; questions were proposed to the missionaries by the Rev. G. Burder, D.D.; the band of missionaries made a confession of the solemn truths they thereby undertook to teach the heathen, and then a dedicatory prayer was offered by the venerable and venerated pastor of Mr. Morrison, the Rev. Dr. Waugh, accompanied by the laying on of hands; then the Rev. Dr. Nicol delivered an affecting charge from Acts xx. 17-27, and the Rev. C. Buck concluded with prayer. It was a deeply touching and impressive service, and was long remembered by those present, not only because of the memorable addresses and prayers of the venerable brethren, but even more by the simple and natural statement by Mr. Morrison of his experience and faith.

His letters to his father, his brothers, and sisters, on bidding farewell to England, overflow with affectionate feeling, especially regarding those who had not become Christians. Thus he wrote to his sister Hannah: "My dear, dear Hannah, do think of your soul now ; set heaven 
and hell and a dying Saviour before you. My brotherly love to your dear partner; tell hin these things from me. Bow down together, and call upon God with tears, and for the sake of Jesus ask for mercy. I hope to go to-morrow, or Wednesday morning at the latest, to Gravesend, to embark for New York. I am in good health, and am not depressed; I sorrow to leave you all, but I do hope and pray (oh, God grant it!) that we shall in a little time be brought to glory everlasting. But, dear sister Hannah, I stand in doubt of you lest you should be in an unconverted state. Forgive me, forgive me; it is not in harshness but in love for your precious soul that I speak. Come to Jesus ; come to Jesus. There is nothing worth attending to till that be done." The intensity of this pleading shows the spirit of a true evangelist and missionary.

In his farewell letter to his father he gives the following particulars as to the arrangements made for his voyage and settlement: "I have letters of introduction to a great many Christian friends in New York who will endeavour to obtain for me a residence in the American Factory in Canton. The Society puts into $m y$ hand $£ 150$ in dollars, which $I$ am to keep untouched till $\mathrm{I}$ arrive in China, as I have my passage paid. I have, moreover, $£ 20$ for current expenses. They give me likewise letters of credit to the amount of $£ 200$ on persons in Canton, Malacca, and I'rince of Wales' Island. I an instructed to act very much as circumstances may arise, and to provide either in whole or part for myself if I possibly can. 'Thus you see that there is not any care wanting, but every precaution that can be is taken."

Mr. Morrison proceeded to Gravesend, and embarked in the ship which was to convey him across the Atlantic. His feelings were profoundly stirred. He wrote: "I am alone; to go alone. Oh that I may not be alone; but that the good hand of my God may be upon me, and the angel of His presence go before me! What is my object in leaving friends and country? My object was at first, and I trust 
still is, the glory of God in the salvation of poor sinners. Oh for faith in God! Oh for strong confidence in the great and precious promises!"

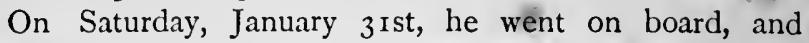
sailed out of the river on his way to his chosen sphere and calling.

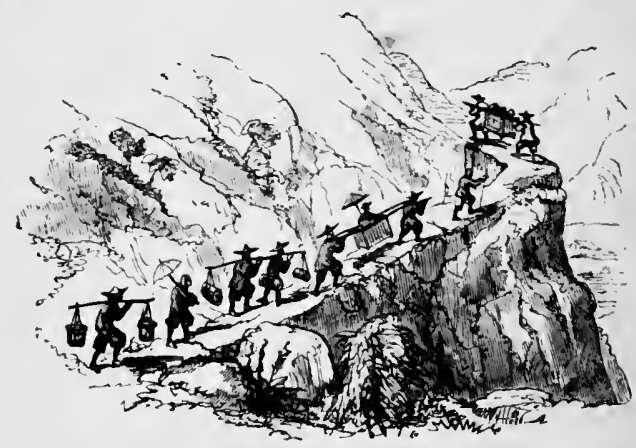




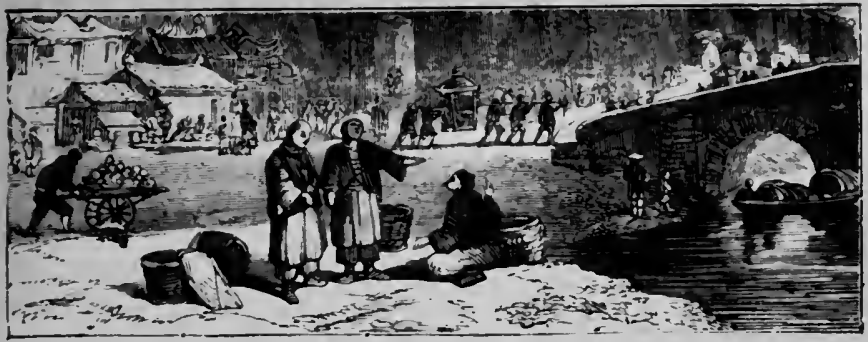

\section{CHAPTER VI.}

\section{INITIAL LIFE AND IVORK IN CIINA.}

"There is no substitute for thorough-going, ardent, and sincere earnestness."-Dickens.

"Prayer and painstaking will accomplish everything."-Jorin Elıor.

FTER leaving Gravesend, the ship Remittance, containing Mr. Morrison and his fellow-missionaries, who were bound for the mission field in India, was detained in the Downs waiting for a fair wind. On February 7 th, 1807 , a tremendous storm raged, which occasioned great destruction of shipping, so that a number of vessels were sunk, and many driven on the shore. Out of a large flect which was anchored in the Downs, the Remittence was the only one that was able to pursue the voyage. It was indeed a serious time. Mr. Morrison wrote as follows concerning it on the 19 th :-

"God has preserved us. Yesterday morning I hoped to have sent this letter on shore by the pilot, but the gale came on so suddenly that he could not leave the ship. Before daylight our anchor snapped in two, our mizen and fore sails split, and we scudded down the Channel under bare poles. The sea ran mountains high, and the atmosphere was so thick with snow that we could not see the 
length of the ship around us. In the midst of our extremity, an alarm was raised that the ship was on fire owing to the bursting of some bottles of vitriol. The pilot and one of the men leaped into the mizen-chains in order to jump overboard-which was to cast themselves into the arms of death-as thcy preferred death in that form to being burnt to death. Happily, however, the other men had courage enough to seize the bottles and push them overboard. My mind, in the midst of this, was only exercised in casting my burden upon the L.ord."

After a long, tedious, and trying voyage, Mr. Morrison at length reached New York on April 2oth, and at once took steps to secure a passage to Canton. He obtained intercourse with several of the leading Christian ministers and laity of the city, and then proceeded to Philadelphia, in order to obtain, if possible, from the Government the interest and protection of the United States Consul at Canton. There he found friends, who used their utmost influence at Washington, and succeeded in obtaining a letter from Mr. Maddison, then Secretary of State, addressed to Mr. Carrington, the Consul at Canton, requesting him to do all he could, consistently with the interests he represented, to further the designs of the mission.

He had great difficulty in procuring a passage to China. There was only one vessel bound for India, and the captain, apprehending difficulty with the British Government, absolutely refused to take any passenger. Another was bound for China, but the owners demanded one thousand dollars for the passage. At last a gentleman, to whom he had been introduced by Dr. Mason, a leading clergyman of New York, arranged for him to sail in the Trident, commanded by Captain Blakeman, who kindly offered to take him to Canton, only charging him for the amount of his stores.

The gentleman at whose house Mr. Morrison was entertained in New York communicated, many years afterwards, 
a paper to the Obserier, which narrated many interesting particulars in reference to this visit. A few extracts from this paper will throw further light on the character of Mr. Morrison, and the spirit in which he anticipated entering upon his work. The writer says :-

"I shall never forget the evening on which the Missionary Company was brought to my house by Dr. Mason. The appearance of a Missionary of the Cross then was a rare thing, and that of a company of missionaries still more so. The countenance of Morrison bore the impress of the effect of grace on a mind and temperament naturally firm and somewhat haughty. His manner was civil rather than affable, serious and thoughtful, breathing a devoted piety. The interview was solemn, but pleasant. Strangers born on different sides of the Atlantic, there was but one bond between us, yet the Divine nature of that 'mystic tie' was speedily recognised as Christian communion unlocked the hidden treasures of the heart; and when, at the close, we bowed our knees in social prayer, the tears which fell on every side were witness to that strange affection to an unseen Being, and all who love Him, which knows nothing of oceans or separating mountains, nothing of distance or of time.

"In a day or two after Mr. Morrison was seized with sudden indisposition. As I sat by his bed, he took my hand, and, adverting to the uncertain issue of the attack, expressed, in language which told of a mind at ease and prepared for every event, his resignation to the Divine will. After urging me to greater devotedness to the cause of Christ's glory, he closed with these words, which I afterwards found were ever on his lips, 'Dear brother, look up, look up!'

"As the notice had been vary short, he was placed for the first night in our own chamber. By the side of his bed stood a crib, in which slept my little child. On awaking in the morning, she turned, as usual, to talk to her mother. 
Seeing a stranger where she expected to have found her parents, she roused herself with a look of alarm; but, fixing her eyes steadily upon his face, she inquired, 'Man, do you pray to God?' 'Oh yes, my dear,' Mr. Morrison replied, 'every day. God is my best friend.' At once reassured, the little girl laid her head contentedly on the pillow and fell fast asleep. She was a great favourite with him ever after.

"There was nothing of pretence about Morrison. An unfriendly critic might have said he was too proud to be vain; a Christian would more willingly have said he was too pious to be proud. Nothing could be more plain, simple, and unceremonious than his manners. His fellowmissionaries looked up to him as a father, resorted to his room for prayer, and took his advice in all their movements. He exhibited less of the tenderness of the Christian than they did; his piety had the bark on, theirs was still in the green shoot. His mind stood firm, erect, self-determined; theirs clung to it for support, and gathered under its shadow for safety. . . . I will only add a brief notice of the parting scene as he left us for his destination. On the morning he sailed, his missionary companions assembled in his room, and there had a most solemn interview - their last in this world. Poor Gordon was completely overwhelmed. Morrison was composed and dignified. He reproved the excessive grief of his brother, and conducted their parting devotions with great firmness and self-possession. We then set out together to the counting-house of the ship-owner, previous to his embarkation. I cannot forget the air of suppressed ridicule which lurked in the merchant's features and in his speech and manner towards Morrison, whom he appeared to pity as a deluded enthusiast, while he could not but secretly respect his self-denial, devotion, courage, and enterprise. When all business matters were arranged, he turned about from his desk, and, with a sardonic grin addressing Morrison, whose countenance was a book wherein 
men might read strange things, said, 'And so, Mr. Morrison, you really expect that you will make an impression on the idolatiy of the great Chinese empire ?' 'No, sir,' said Morrison, with more than usual sternness 'I expect GoD will.' We soon left the man of money, and, descending to the wharf, took our last farewell of the future apostle of the Chinese, as he stepped into the stern-sheets of a boat that was to carry him to the ship that lay off in the bay. He said little, he moved less; his imposing figure and solemn

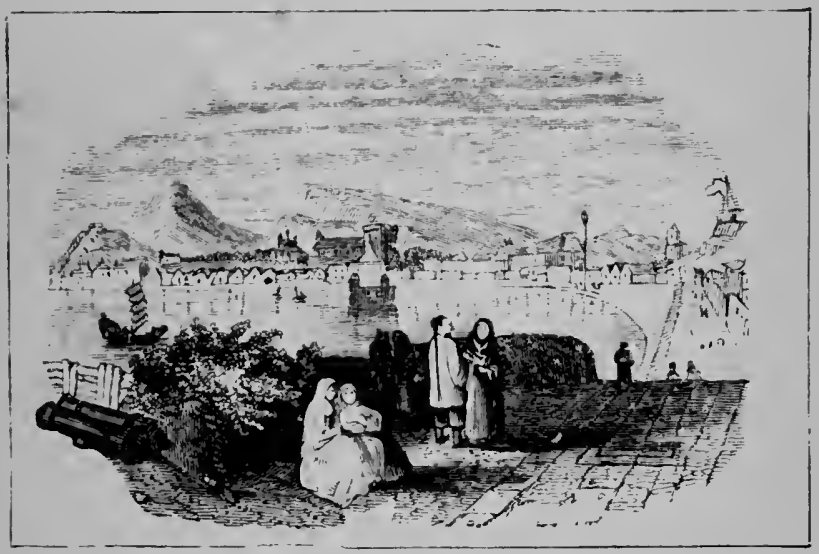

MACAO.

countenance were motionless as a statue. His mind was evidently full, too full for speech: his thoughts were with God, and he seemed regardless of all around him. By the return of the pilot I received an affectionate note."

He sailed for his destination in the Trident about the middle of May, and reached China in September 1807 . No incidents of special interest occurred during the voyage, but he frequently preached on board with great earnestness, and was unremitting both in ministering to the religious welfare of all on board, and in pursuing his own studies. 
He gives a very graphic account of "crossing the line," which illustrates the rough horseplay which was in vogue amongst the tars of that period.

"As we passed the equinoctial line our people went through the ceremony of ducking. Neptune and Amphitrite, most ludicrously dressed, he having an immensely long beard and tail, with a trident in one hand and a speaking trumpet in the other, she clothed in a rough, shaggy skin, presented themselves in the forecastle. The men who had before crossed the line accompanied the god and goddess, having their trowsers and shirt sleeves rolled up so as to present their legs and arms bare, painted, or rather bedaubed in a most rude manner. Neptune hailed the ship, to which a person answered in the steerage. Advancing with the goddess and their retinue to the quarterdeck, 'I understand,' said he, in a hollow, grumbling voice, 'you have some of my children here who have not before passed this way; bring them out that I may see them; bear a hand !' One was immediately brought, blindfolded, by two conductors. Each of them laid a large cudgel on the man's shoulder. Having dragged him before Neptune, they seated him on a half barrel full of water. 'Well, my son,' said the god, 'I am glad to see you pass this way; you must now hail the line,' putting the trumpet to his lips for that purpose. He cries, 'Line a-ho!' at which instant a seaman throws with violence a pail of salt water down the trumpet into the man's mouth. 'Come now, barber, and shave my son,' says Neptune. 'The man steps forward with a large painter's brush, and bedaubs the man's face and neck with tar or black paint. Amphitrite gives him a cordial-viz., a glass of salt water. An old rusty hoop is then applied to the man's face, and as the tar is scraped off the razor is wiped between his lips. 'Now,' says Neptune, 'you must make some vows to me; first, you must never eat brown bread when you can get white, unless you like it better.' 'Yes,' answers the man, between whose lips a 
tarry stick -is thrust, that he may, as they say, 'kiss the look.' 'You nuust never drink water when you can get wine or porter; you must never leave the pump till it sucks; you must serve as you have been all who come this way.' To each of these the man must reply, and when he opens his lips the tarry stick is thrust into his mouth. Six or eight buckets of water are then dashed against him, his seat is removed, and he tumbles down in the dark, almost suffocated, amidst the loud laughter of his shipmates." Half of those on board were thus treated, but fortunately, through the intervention of the captain, Mr. Morrison was spared the ordeal."

Before reaching China he called at Macao, an island on the coast about ninety miles from Canton, and which then belonged to the Portuguese Government. Here the East India Company had a Factory, and on landing he was surprised to find there Sir George Thomas Staunton, the President of the Select Committee of the East India Company. He also met Mr. Chalmers, chief of the Factory at Macao, and presented to him a letter of introduction he had brought from Mr. Cowie, one of the 1)irectors of the Missionary Society. Mr. Chalmers welcomed him heartily, and wished him success, but said, "The people of Europe have no idea of the difficulty of residing here or of obtaining masters to teach." He told Mr. Morrison that the Chinese were prohibited from teaching the language under penalty of death. He also promised to talk the matter over with Sir George and Mr. Roberts, the chief of the English Factory at Canton. Then Mr. Morrison waited on Sir George, and presented a letter of introduction from Sir Joseph Banks, the President of the Royal Society. Sir George also spoke seriously as to the difficulties of the enterprise, stating that the East India Company forbade any one to stay there, save on account of trade; hut eventually he promised that he would do all in his power to promote the object Mr. Morrison had at heart. Sir 
George was supposed to be the only Englishman living who had a proficient acquaintance with the Chinese language. He was a gentleman of noble spirit, and this introduction ripened into a life-long and ardent friendship between him and the missionary.

On his arrival at Canton Mr. Morrison sought an interview with Mr. Carrington, the United States Consul,

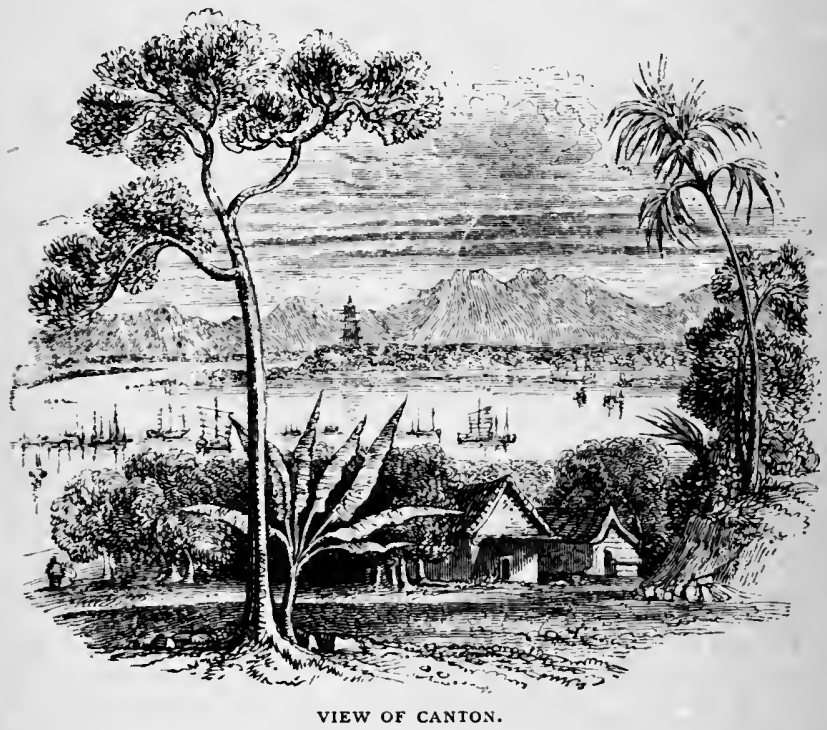

and presented Mr. Maddison's letter. $\mathrm{He}$ received a cordial welcome, and was offered a room in the Consul's house, which he gratefully accepted. But as this house was thronged with visitors, he soon removed to another, occupied by Mr. Milnor, where he was more retired, and able also to live at less expense. This house was part of the old French Factory at Canton, then in charge of Mr. Milnor and his partner Mr. Bull, as super-cargoes. He received 
great kindness from these gentlemen, and as an American citizen he remained under their protection. As an Englishman he dared not be known.

From Canton he wrote to Sir George Staunton, as follows: "Sir George is most respectfully informed by R. Morrison that he has at present an apartment in the old French Factory at Canton. If Sir George thinks any particular line of conduct necessary for Mr. Morrison to pursue, in order to his being permitted quictly to reside in Canton, to communicate it will be rendering Mr. Morrison an essential service. Mr. Morrison will wait the arrival of Sir George at Canton, before any attempt be inade to procure assistance in learning the language."

When Sir George came to Canton he at once introduced Mr. Morrison to Mr. Roberts, the chief of the English Factory, and also obtained for him a teacher. This was Abel Yun, a Roman Catholic Chinese from Pekin; and from this time he devoted himself with extreme diligence to learning the language. It is scarcely possible for us to realise the cautious prudence required from Mr. Morrison at this point in his career. One false step must have precipitately closed his carcer in China, but the difficulties which gathered round him only seemed to fire his zeal and develop the resources of his nature. In writing to the Society he detailed his various movements at great length, and gave utterance to the decp feeling within his breast, in words as follows: "It is a hazardous but not a doubtful enterprise on which we enter-doubtful, I mean, whether we be right or wrong. We shall not have to reproach ourselves for having published the truth of the Gospel amongst ignorant, deluded, guilty men. The missionary of Jesus will have cause to reproach himself that he served not his Lord more fully, but not that he was a missionary. O Calvary, Calvary, when I view the blood of Jesus streaming down thy sides, I am amazed at my coldness of affection towards the Lord, of my slothful performance of the duties 
which the authority of God, but shall I say, which the love of Jesus more strongly imposes upon me. Yes, O Father, Thy love in sending Jesus, and, O my Saviour, Thy love in giving Thyself for me, and Thine, O Holy Spirit, in applying the salvation of Jesus to my guilty conscience, unitedly overcome me, and constrain me to live not to myself but to Thee."

He gives also an account of the opportunity opened to him of learning the language, a work that must necessarily precede any other step in the direction of the accomplish. ment of his great task.

"There are two Chinese who will, I hope, be useful to me; at present, however, they are so. The name of one is Le Sëensang. He possesses considerable knowledge of Chinese, writes an exçellent hand, and having obtained one degree as a man of letters, is not so afraid as some of the tradespeople are. The other person, Abel Yun, was sent to me by Sir George. Abel is here the agent of the Romish missionaries at Pekin, a native of Shan-si, where the Mandarin language is generally spoken. A great part of his life (he is about thirty years of age) has been spent with the missionaries at Pekin. They have taught hin the Latin language, which he speaks fluently. He came to me to-day, accompanied by another Christian. Being the Lord's Day I could not receive instruction from him. The Vulgate translation of the Scriptures was lying on my table. On his looking at it we entered into conversation respecting its contents. I turned to the fourth Commandment in Exodus, and to the closing verse of the 58 th of Isaiah. He read them, explained them to his Chinese friend, and if I understood him rightly, said he had hitherto erred respecting the Sabbath. He alluded with readiness to the discourse of our Lord respecting the Sabbath, when some said that He profaned it by healing on that day."

Mr. Morrison's position was a trying one, because of its isolation and uncertainty. He knew that at any moment 


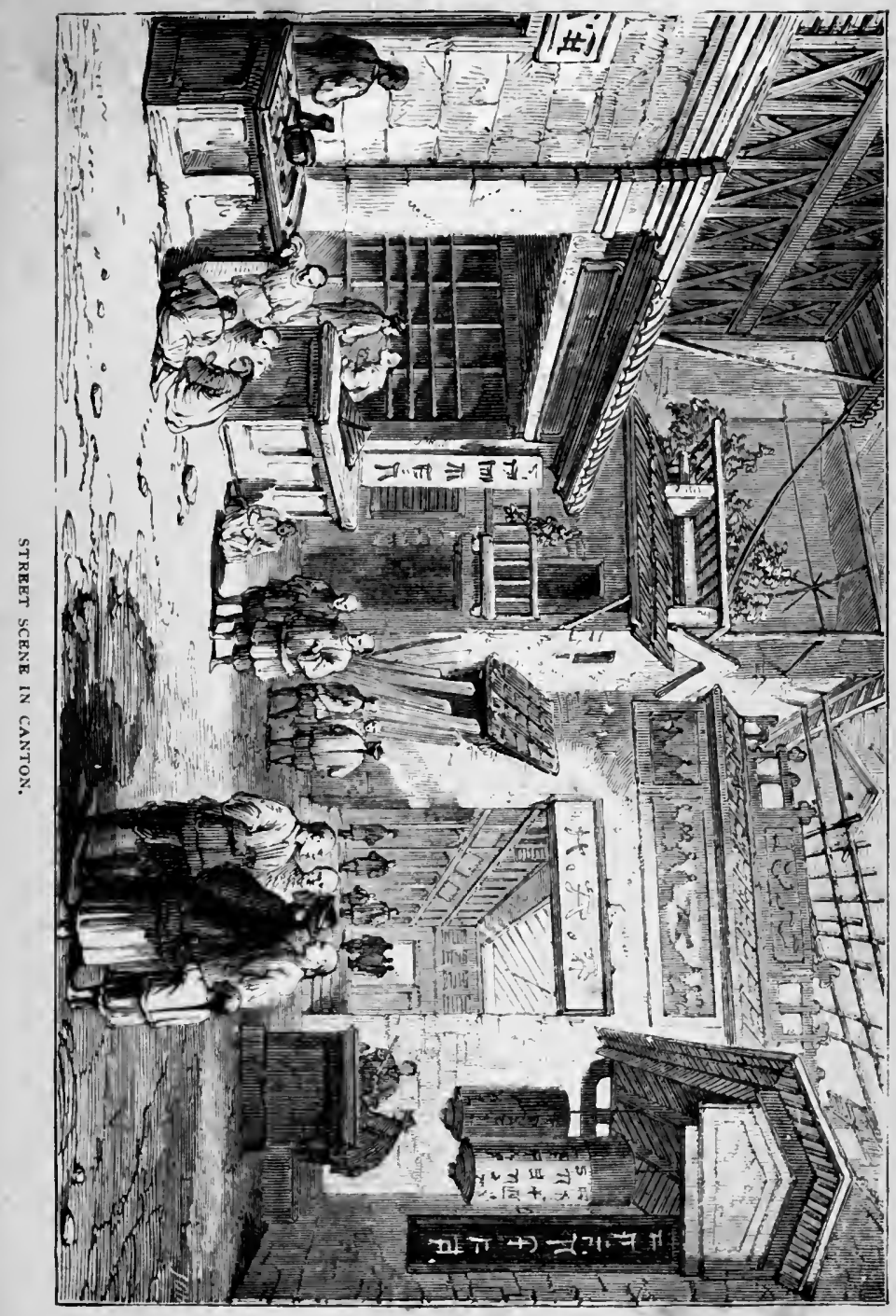


he might be ordered to leave the country, and his expenses were very great. His rooms in the Factory cost him $35^{\circ}$ dollars a year. His board 400 more. He had to keep a boy, which cost 100 dollars. 'Then he had the expense of a teacher, candles, furniture, books, and other necessaries, besides which he on several occasions became a prey to the merciless and deceitful covetousness of the natives. $\mathrm{He}$ employed a Chinese to buy him a few books in the city, and this person bribed the boy to aid him in defrauding his master, which he succeeded in doing to the amount of thirty dollars. His early impressions of Chinese superstition and idolatry he described to his friend Cuthbert Henderson, at Newcastle, thus :-

"By the Lord's good hand upon me I am preserved in health amidst very close application to the Chinese language. I have some opportunities of saying a few things concerning Jesus in private conversation, but cannot make myself understood for want of words. I find much difficulty in speaking of God, for the Chinese have no proper idea of one living and true God, and consequently have no words to express such an idea. Your heart, dear Cuthbert, would be grieved to see them falling down prostrate, or on their knees, touching the earth with their foreheads, before large figures in the form of men. Sometimes, instead of a graven image, they have a painting of a man. The person worshipping kneels, and on his knees keeps the body erect a short time, then bends forward, and placing his hands on the floor to support his body, brings the forehead into contact with the stones or earth, of one or the other of which their floors generally are. He again raises his body erect, and again bends forward three times. He then stands up for a short time, after which he kneels and goes over the same number of prostrations a second and a third time. To what a low state has sin reduced man! Why this external adoration of a lifeless image? Blessed book the Bible, which reveals to man the true God, and which reveals man 
to himself. Blessed Jesus, who was in the bosom of the Father, and who has declared Him to us."

The rooms which Mr. Morrison occupied were called in

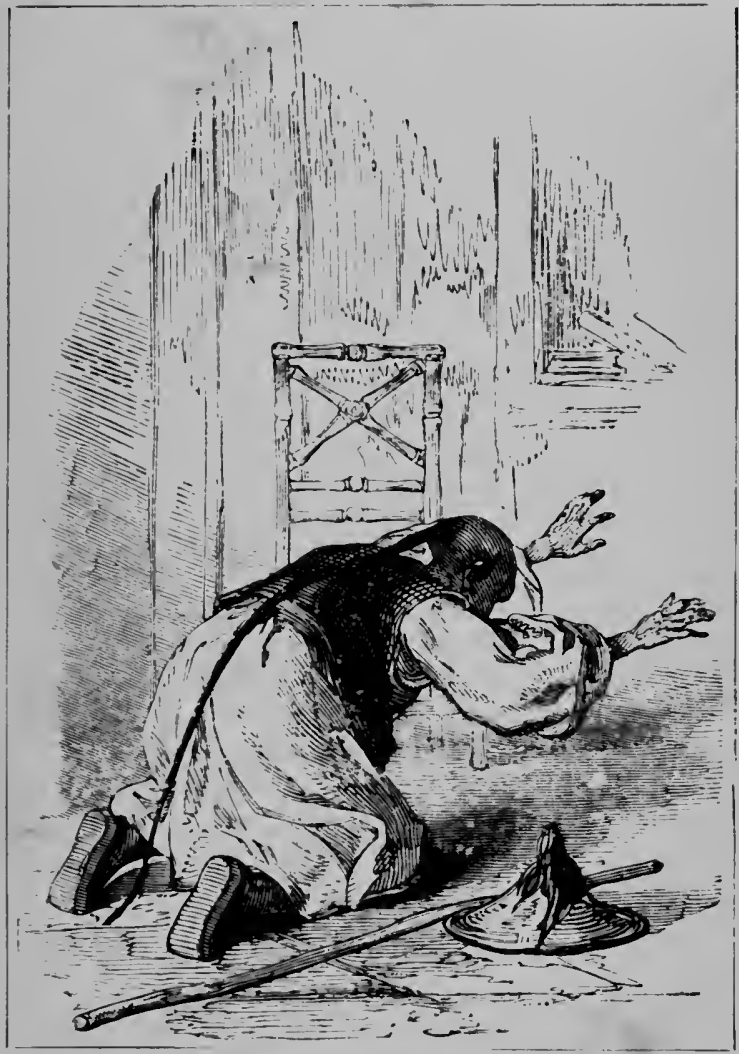

CHINESE WORSHIP.

Canton a "go down." They were, in fact, simply a basement story, and had been commonly used as warehouse rooms. In these he studied, ate, and slept. In order that 
he might attract less attention, he adopted the dress, food, and habits of the natives. He wore a pig-tail and loose dress, he ate with chopsticks, he allowed his nails to grow long. So closely did he devote himself to study, and so little did he eat, that in a short time his health failed, and his life was in sericus peril. Without questioning the excellence of his intentions, the wisdom of some of these steps he himself afterwards doubted, as the following lines from Dr. Milne's "Retrospect of the First Ten Years of the Chinese Mission," * which was mainly prepared from an account written by Mr. Morrison himself, will show :-

"At first he supposed it would greatly facilitate his object to live in the manner of the natives; and under this idea he supplied himself with such articles as are commonly used by the Chinese in dress and at meals; but he shortly perceived that the idea was erroneous. To make himself remarkable in external appearance would have been proclaiming to the Chinese that he was not in circumstances similar to those of other foreigners at Canton, and that he had objects different from those of commerce, which is the only one sanctioned by the local and general authorities. Again, as religion does not consist in the form or colour of one's dress, he not only declined assuming a native dress, but also did not make a point of being always dressed in black; the white jacket and straw hat were worn, as other Europeans do in warm climates. Whatever may be becoming in other countries, in those places where the Governments are averse to the diffusion of Christianity, all external distinctions of this kind had much better be laid aside by missionaries; let piety towards God and benevolence towards men be the characteristics which distinguish them.

"At first, as above observed, he ate in the Chinese manner, and dined with the person who taught him the language. His mode of living was rigidly economical. A

$$
\text { * Pages } 64,65 .
$$


lamp made of earthenware supplied him with light; and a folio volume of Matthew Henry's Commentary, set up on its edge, afforded a shade to prevent the wind from blowing out the light. He did not find, however, that dining with a native increased his knowledge of the language; in the time of taking a hasty meal little advantage was gained. The same reason which led him to pare his nails, cut off his hair, and give away his Chinese dress, induced him to desist from being singular in his manner of eating also. His nails were at first suffered to grow that they might be like those of the Chinese. He had a tail (i.e., a tress of hair) of some length, and became an adept in the use of chop-sticks. He walked about the Hong with a Chinese frock on, and with thick Chinese shoes. In this he meant well ; but, as he has frequently remarked, was soon convinced that he had judged ill."

Soon after his settlement in Canton he attempted to hold public worship in his rooms, and invited a few American and English gentlemen to attend. He had much discouragement and disappointment in the effort. In order to conciliate some who were members of the Church of England, he made use of the Liturgy; but he found, to his sorrow, that residence in a heathen land too often fostered indifference to Divine worship, rather than imparted a greater desire for it.

From the commencement of his residence in China Mr. Morrison strove to induce his native teachers and servants to observe the Sabbath. He, of course, gave up all work on that day, and engaged in private or public worship, as he had opportunity, and thus set them an example which he hoped would produce a happy result. When he could induce then to stay with him he got them to read the manuscript copy of the Harmony he had prepared in London, giving exposition and application of it as he had the opportunity. He tried also to get them to unite with him in singing and prayer. Although he did not make 
these efforts in vain they were not crowned with the success they deserved.

As Mr. Morrison became more accustomed to his position, he removed from the small and unhealthy "go down" which he occupied, and rented a building called "The Factory," which had been occupied by the French, but which was offered to him by Mr. Parry. He had here

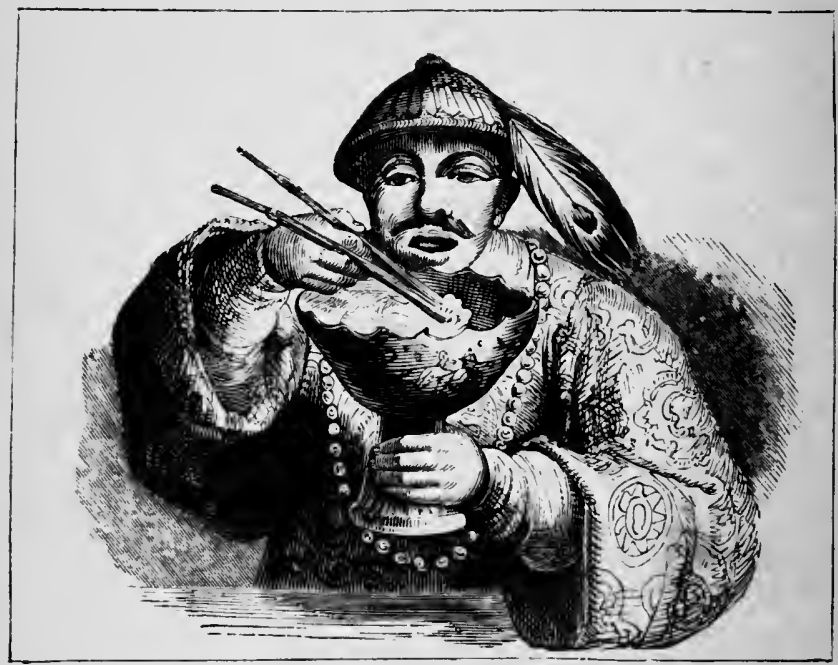

EATING WITH CHOP-STICKS.

more room and convenience, and here he resided till he was obliged to leave Canton by reason of failing health.

His character and pursuits began to draw towards himself the attention and friendship of the leading foreigners in Canton. Mr. Roberts, the chief of the English Factory, showed increasing disposition to further both his literary studies and missionary aims; Mr. Ball, another leading employé of the East India Company, also offered him considerable sympathy; the Hon. J. Elphinstone sent him a present of a Latin-Chinese Dictionary, valued at $\varnothing_{50}$; 
and Dr. Pearson, the medical attendant of the Company, offered to him and his family the most efficient and considerate attention for twenty-five years. Above all, Sir George Staunton showed himself a friend indeed, and in every need, as long as he lived.

The anxieties of his situation, and his unremitting application to study without sufficient air and exercise, so told upon his strength, that he was unable to walk across the room. His physician advised a change of air, and by the agency of the gentlemen just referred to a residence was obtained for him at Macao, where he removed on June ist, in a condition of great mental depression. 'There is no doubt that his desire to economise the funds of the Society led him to exercise a measure of self-denial that must have been injurious to the strongest constitution. But as to his mission he maintained a firm spirit, and "bated not one jot of heart or hope, but still held on most bravely."

He remained at Macno till the end of August I808, studying with his Chinese assistants, and his health improved so much that he was able to return to Canton. In November political difficulties arose, which led to all Englishmen being commanded to leave the city. He remained for a brief period on board ship, and then returned to Macao, where he took up his residence in his old quarters. A few days afterwards Low Hëen, one of his teachers, ventured also to Macao, but he was in great peril from his countrymen, who were strongly opposed to any Chinese residing with foreigners.

A few days after Mr. Morrison's arrival at Macao, a young gentleman called upon him to say that his father, Dr. Morton, had a letter for him from the Rev. Mr. Loveless, an event which had a very scrious influence upon his future. He invited Mrs. Morton and family to come to his house, and unite with him in social prayer. On the following Sabbath the whole family spent the day with him, and united in Divine worship. The young man, William 
Morton, manifested great desire for the salvation of his soul, and Mr. Morrison entertained hopes that he might be induced to give himself to missionary work altogether. The loneliness of his position was greatly relieved by intercourse with this Christian family, and between Miss Morton and himself there soon sprang up a warm attachment, which, by-and-by, culminated in their marriage. She was led by Mr. Morrison to give herself entirely to God's service, and he thus became the instrument of her salvation.

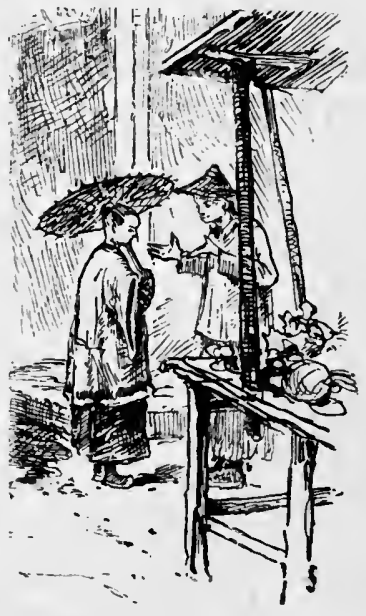




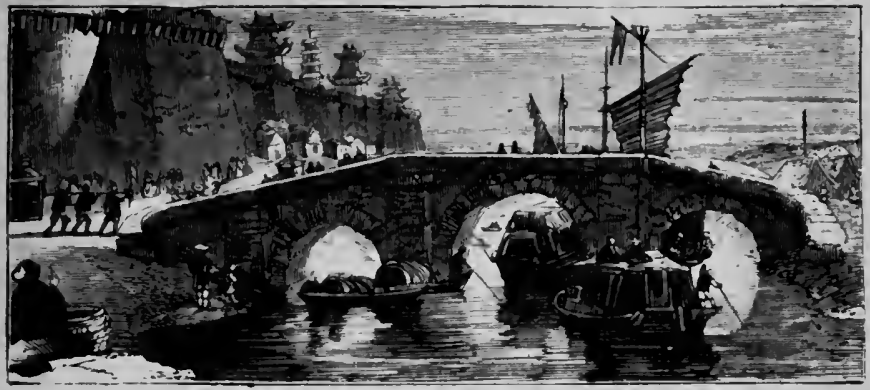

CIIAPTER VII.

PERSECUTION.-LONGING FOR SUCCESS.

"Some men live near to God, as my right arm

Is ncar to me; and thus they walk about,

Mailed in full proof of faith, and bear a charm

That mocks at fear, and bars the door on doubt,

And dares the impossible."-Blackie.

\section{D}

IFFICULTIES as to Mr. Morrison's continued residence as a missionary at Macao, or in any part of China, increased around him so seriously that he resolved to leave and proceed to Penang, and there continue his study of the language until his way to re-enter China was open. He made preparations for his departure, when Providence interfered to arrest his flight. The opposition arose from the jealousy of the Chinese and the enmity of the Roman Catholic missionaries combined, and in addition to this, decided opposition was displayed by some of the chief employés of the Factories. What, therefore, must have been his surprise when, on the very day of his marriage to Miss Morton, February 2oth, r 809 , he received a request to become the official Translator of Chinese for the East India Company, at a salary of $£_{500}$ per annum. If any fact could testify to his proficiency in the language and to the prudence and consistency of his 
character, this does so in the most ample way. This offer decided his destiny, and to a great extent the future of Christian missions in China. There was no need now to embark for Penang; Macao or Canton were both open to him for residence and for pursuing the great enterprise of his life.

Mr. Morrison had so far succeeded in obtaining a knowledge of the language, that he had prepared a Chinese Vocabulary, made considerable progress with his AngloChinese Grammar and Dictionary, besides having given much attention to the translation of the New Testament, which he was slowly preparing. He was, however, greatly troubled by the capriciousness and ill-temper of his Chinese assistants. One of them, when Mr. Morrison was alone onc evening, tore his coat from his back, and was proceeding to assault him, when his master called some gentlemen in the neighbourhood to his assistance. Yang-Sam-Tak, who had come out to China, and had been engaged to teach him, sent away his other two helpers, and gave him intense distress by his violent temper and his high-handed doings. Still he did not venture to resent this ill-treatment, or he might have been left without a teacher altogether. On the contrary, he bore with them, prayed with them, expounded the Word of Life to them, and yearned night and day for their salvation. Then his house was a miserable one. The roof fell in; but he would still have clung to it, only the landlord raised the rent by one-third, because his house, he said, had been turned into a chapel. Therefore Mr. Morrison had to seek another residence. So afraid was he of being noticed by the people of Macao that he never walked out, much to the injury of his health. The first time he ventured to walk into the fields, skirting the town, was on a moonlight night, in company with his two teachers. Indeed, his standing in Macao was so precarious that he was strained with continual anxiety lest by any step he should bring about his dismissal. This 
severe mental tension occasioned a renewal of torturing headaches, to which he was constitutionally prone, and subjected him to other attacks of illness. His marriage with Miss Morton also added to his other trials, as her health began to fail shortly after their union, and she became a permanent invalid. One more disappointment came to try him. His brother-in-law, William Morton, was obliged to relinquish his studies, give up the calling of a missionary, and seek a more favourable climate by reason of his delicate health.

The offer which came to him from the East India Company was undoubtedly a great relief to his mind. In accepting it he had the full approval of the Directors of the London Missionary Society. There are some who have blamed him for accepting an office of a civil character, and the functions of which were outside of his sacred calling as a Missionary of the Cross. But such do not seem to thoroughly grasp the difficulties of his situation. In entering on these duties Mr. Morrison saw at once that he would have new facilities afiorded him of becoming familiarised with the language, that he would be able to remain in the country, and that he would not be burdensome to the Society; whilst he would be able to discharge fully his duties to the Company, and still give the major portion of his time to the work of his life. The course of events fully justified the step taken. By becoming an employé of a great, wealthy company, he would be protected at once from the hostility of the natives and the Romish emissaries.

The steps he took to make known the Gospel to the Chinese were necessarily of the most quiet and limited character. Indeed, to preach publicly had never been the purpose of the Socicty until the conditions of things should entirely alter in China. Still, Mr. Morrison could not rest without doing something to make known the way of salvation to the heathen around him. His own teachers and servants were his first hearers. On the Sabbath, the 
Harmony of the Gospel in Chinese, which he had taken out with him, was read. The enormous difficulties to an Englishman of learning the language made it for a long time impossible for him to give any fair view of Christianity, or to argue with the Chinese as to their false systems. But the effort was made; one or two, sometimes from four up to ten Chinese, would be gathered in an inner apartment, and the door securely locked; then the opportunity would be afforded to the missionary of declaring his message. For a long time this was done without any cheering result to encourage or reward his faith.

At the end of 1810 he wrote to his friend the Rev. John Clunie, describing his progress and position, as follows :-

"I have experienced since I wrote to you a considerable share of affliction; not indeed in my own person, but in the person of my dear Mary. A nervous disease strongly agitates body and mind; she is, I thank the Lord, now somewhat better, and I hope will recover her former health and peace. Affliction in a foreign land lies doubly heavy ; no kind relatives to assist, no Christian friend to cheer. The mind in perfect peace will, I know, sustain any deprivation, or merely bodily calamity, but 'a wounded spirit who can bear?' My daily occupations are the same as when I last wrote to you in the beginning of this year. I believe I was then in Canton. I continued there till March, carrying on a discussion with the Chinese Government respecting the alleged murder of a Chinaman. I obtained great éclat by the public examination of the witnesses; everybody was astonished that in two years I should be able to write the language and converse in the Mandarin and vulgar dialects. In consequence of that, three of the Company's servants determined to begin the study of the Chinese language, and I have during the summer been a regular Chinese tutor. In addition to these three, a gentleman who has been twenty years in the country attended; these remained two hours every day, and my fifth pupil, a Dutch youth, remained all the 
day. Through the summer $\mathbf{I}$ have had much translation to do for the Company, and frequent conferences with the Mandarins; neither the one nor the other, I am sorry to say, was amicable. The Mandarins are extremely haughty, overbearing, and clamorous; sometimes three or four of them will speak at the same time, and as loud as if they were all scolding. My tutor Kō Sëen-săng yet continues with me, and also my assistant Low Hëen. I employed him to get one thousand copies of the Acts of the Apostles printed in Chinese, and he connived at my being charged twenty-five or thirty pounds more than the proper price. He told me so this evening, and confessed his fault. It grieves me very much, as I cannot now trust him. It is very desirable to have persons in whom we can place entire confidence, but that is not the case with the Chinese. A want of truth is a prevailing feature in their character; hence mutual distrust, low cunning, and deceit."

It was shortly after this that the translation of the Acts of the Apostles just referred to was published. One thousand copies were printed. The charge for printing was exorbitant, amounting to abouk half a dollar per copy, the price at which the whole of the New Testament was afterwards printed. But, as it was considered to be a prohibited book, some risk was incurred by the printers, and they expected to be proportionately compensated, besides that the Chinese thought themselves at liberty to impose in any way open to them upon the foreigner. Three ambassadors from the Islands of Lekyo, who had come with tribute to China, had copies presented to them on their landing, and the book was cautiously circulated at every opportunity.

Mr. Morrison next prepared a tract, called Shin-taou, or the Divine doctrine concerning the Redemption of the World. This was printed, and one thousand copies issued. Then he translated the Gospel of St. Luke, which was also printed. He also composed a Catechism to put into the hands of inquirers. At this time the authorities of China evidently 
began to be disturbed at the promulgation of other religious views than those long established in the empire, and an imperial edict was issued prohibiting the teaching of Christianity, and four Roman Catholics were expelled from Pekin. These steps rendered Mr. Morrison additionally cautious as to his next movements.

His Chinese Grammar had been ready for some time, but he found it difficult to obtain its publication. He submitted it to Sir George Staunton, who wrote his most cordial approval of it in these words:-

"I return you the Chinese Grammar with many thanks for the perusal. I am happy to congratulate you on a work which will prove, both in regard to its plan and its execution, a most valuable acquisition to the student of the Chinese language. He will no longer be under the hard necessity of working his way through the ponderous volumes of Fourmont, Boyer, and others ; and which, after al!, are often very inaccurate and defective. I hope therefore you will soon proceed to the press."

The Grammar was sent by Mr. Roberts to Lord Minto, the Governor-General of India, in order that it might $b$ ? printed. For sone reason, never explained, it was kept back nearly three years; then it was printed at the Serampore Press, in 18 I 5 , at the expense of the East India Company, and was of signal service to many who hitherto had found the acquisition of the language a task too difficult for them.

Several important events in relation to Mr. Morrison's domestic and family affairs transpired in the year 1812 . His good and pious father died; two of his brothers also passed away; and he was cheered by the birth of a daughter, and the prospect of improved health to his afflicted partner.

As Sir George Staunton had been withdrawn from China, Mr. Morrison's official duties became much more responsible, and his salary was increased to a thousand pounds a year, with allowances for teachers, a place at the public table, 
and other privileges. His services were represented as being of the highest value, and the Honourable Court of Directors, when asked to sanction the appointment which had been made by the Select Committee, gave "a kind of consent to it." The meaning of this apparently tardy consent was that the Directors of the East India Company, both in England and in China, considered it a visionary enterprise to attempt the conversion of the Chinese to Christianity, and also feared that such efforts might be opposed to the commercial interests of the Company. But the prudent and unostentatious, though invaluable labours of Mr. Morrison, won their esteem and admiration, and led them to treat him with great confidence.

He now gave himself with renewed enthusiasm to the preparation of the Anglo Chinese Dictionary-a formidable undertaking, which involved an acquaintance with Chinese classical literature such as no Englishman or European had ever possessed.

Three copies of his translation of the Acts of the Apostles, which he forwarded to England, aroused the deepest interest in the minds of the lovers of missions. The Directors of the London Missionary Society presented one copy to the British and Foreign Bible Society, which liberally voted $£ 500$ towards the printing of the whole Bible in Chinese, when the translation should be complete; another copy was unstitched, and its leaves distributed amongst the friends of the Society in various parts of the United Kingdom. It seemed to them to be the first demonstrated stcp towards the eventual conquest by the Gospel of the whole heathen empire, and they rejoiced accordingly. In the same letter that told him of the welcome reception of his translation, the glad tidings were communicated that at last, in response to his frequent and earnest pleadings, a helper had been appointed to come and share his labours. This was Mr. William Milne, a young man of most devoted piety, and of perfect fitness for the work to which he was designated. 
Mr. Morrison's apprehensions were now painfully excited by an edict against Christianity issued by the Emperor. The following extract from his letter to the Society, dated April 2nd, 1812, will show at once his danger and his calm resolution:-

"By the last fleet, which sailed about a month ago, I wrote and enclosed you a copy of my translation of the Gospel by Luke, and a Chinese tract on the Way of Salvation, which I hoped would reach you in safety. I now enclose you a translation of a Chinese edict, by which you will see that to print books on the Christian religion in Chinese is rendered a capital crime. I must go forward, however, trusting in the Lord. We will scrupulously obey governments so far as their decrees do not oppose what is required by the Almighty. I will be careful not to invite the notice of Government. I am, though sensible of my weakness, not discouraged, but thankful that my own most sanguine hopes have been more than realised. In the midst of discouragement, the practicability of acquiring the language in no very great length of time, of translating the Scriptures, and of having them printed in China, has been demonstrated. I am grateful to the Divine Being for having employed me in this good work; and should I die soon, it will afford me pleasure in my last moments.'

That there was abundant ground for grave fears for the future of Christianity may be seen from the following paragraph from this proclamation: "From this time forward, such European as shall privately print books and establish preachers, in order to pervert the multitude, and the Tartars and Chinese who, deputed by Europeans, shall propagate their religion, bestowing names (i.e., baptising), and disquieting numbers shall have this to look to: the chief or principal one shall be executed. Whoever shall spread their religion, not making much disturbance, nor to many men, and without giving names, shall be imprisoned waiting 
for the time of execution, and those who content themselves with following such religion shall be exiled," etc.

The Directors of the Society, in publishing the persecuting document, remark: "We are pleased to pcrceive that the mind of our Chinese missionary is undismayed by this edict, and that he is resolved to go on in the strength of the Lord, to whose omnipotent care they checrfully commit hin, assured that the set time to favour China is approaching, when this edict, which will act at present as a most extensive proclamation of the publication of the Scriptures and thereby excite the curiosity of the millions of China to peruse them, shall not only be revoked, but followed by another in favour of Christianity."

Mr. Morrison was working with great diligence at his work of translating the Scriptures and compiling his Dictionary. He had printed most of the Epistles, and also the Gospel of St. Luke, already referred to ; but he found the preparation of the Dictionary a task which severely tested his patience and his resources. To the Grammar, which still lay in the hands of the Company, waiting for their decisior. as to printing, he added a volume of Dialogues.

He became increasingly anxious to see some visible result of his efforts to affect the hearts of those natives to whom he had access, and was greatly cheered by being informed that the life of one person, a Chinese police orderly in Canton, had been rcformed through reading the tract published by him on the Way of Salvation, which tract this person had taken up by chance from the table of a relative. He had been a notoriously bad man-too bad, in the estimation of the person who had distributed the tracts, to receive one. 'The reform in his life was marked by many, but did not result in his beconing a Christian.

Other faint signs of success began to brighten before his mind. His Chinese assistants were evidently becoming familiarised with Divine truth, and proportionately became convinced of the sin and absurdity of idolatry. Several 
entries in Mr. Morrison's journal seem to make this evident :-

"October I Ith. Lord's day.-Discoursed on the parable of the Prodigal Son. My people, as usual, were attentive. In the evening A-Tso read part of the tract, and explained it in a satisfactory manner. He mistook the original righteousness of man for the time of every one's birth. A-Fo also read it, and attempted to express the sense in his own language, but misunderstood its scope. He proposed to attend on the Lord's days and at the usual times of worship. In the evening $I$ heard the boys repeat their catechism and read a chapter of the Gospel by St. Luke. As usual they were dismissed with prayer. They all appear to feel the absurdity of idol worship. Kõ Sëen-săng seems ashamed of it. The truth appears to have enlightened him in some degree. I asked him some time ago if any of his countrymen with whom he was acquainted affirmed that there is no God. He did not give a direct answer, but said: "How can any affirm it, when the heavens and the earth and all things were made by Him ?' Kō Sëen-săng is a man fortyfive years of age. His father was a Mandarin of some rank. $\mathrm{He}$ is of a mild and amiable disposition, of good natura! parts, and has been accustomed all his life to teach. Low Hëen is about thirty, is mild, but insincere. He writes a good hand, and is very useful in writing for the press. Kō Sëen-săng revises what is translated. 'They both do their parts without scruple."

A-Fo cheered hin by apparent increasing earnestness in his inquiries after Scripture doctrine. Kō Sëen-săng manifested growing interest in sacred subjects; but the young boys gave him most pleasure and encouragement. One day A-Fo brought him some idols to look at. He desired that his countrymen might not be told he had brought them, because they would be extremely angry if they knew of it. 'They were greatly opposed to selling or parting with their idols, lest they should be insulted. "For my part," said 
A-Fo, "I believe in Yay-soo (Jesus), and hearken to what you say of the vanity of worshipping wooden, clay, and other images." On November 8th, 18r2, A-Fo inquired about baptism, and declared his willingness to be baptised if his brother might not know of it. Mr. Morrison endeavoured to explain to him that if his motive was a prudential one, in order to avoid drawing the attention of the civil authorities to himself, it was allowable; but if he was ashamed to be known as a Christian, it was not. He remained with the missionary after the others had gone for further instruction, and for weeks repeatedly asked him to offer prayer with him and for him. He seemed to be really sincere in his desires for salvation.

The Roman Catholic Bishop at Macao issued an anathema against any who had intercourse with Mr. Morrison, or received his books, or supplied him with Chinese books; but it had no appreciable effect on his work. He reports as to his efforts for the conversion of the natives thus: "I have endeavoured to communicate to a few, by oral instruction, the knowledge of the truth. [Here follow the names of eleven persons.] These have attended with the utmost seriousness and the utmost decorum. In Macao every Sabbath day I conducted worship with the above persons. I began by prayer, next read a portion of the Scriptures, some part of that which I have already printed, or some portion translated for the occasion. These I endeavoured to explain and enforce, and then concluded by prayer and singing a psalm or hymn." Another evidence of growing serio'ssness is afforded in the following extract:--

"December 18th.-Kō Sëen-săng, who has been at home for several days presiding at the marriage of his son, returned to day. In the evening he had again to go lome. $\mathrm{He}$ therefore requested me that $\mathbf{I}$ would engage in family prayer sooner, that he might join in it ; for he felt uncomfortable in his mind from not having engaged for several days. I bless God for this sign of an awakened mind. 
O Lord! carry it on to complete conversion, through Jesus Christ."

It was just now that Mr. Morrison first broached to the Directors of the Missionary Society a project he was some years afterwards able to realise in large measure-viz., the establishment of a Missionary College at Malacca. $\mathrm{He}$ says: "I wish that we had an institution in Malacca for the training of missionaries, European and native, and designed for all the countries beyond the Ganges.' 'There also let there be that powerful engine the Press. The final triumphs of the Gospel will be by means of native missionaries and the Bible; the spring that gives motion to these, under God-European Christians. We want a central point for our Asiatic missions, we want organised co-operation, we want a press, we want a committee of missionaries. Such a committee, being engaged in missionary work in heathen lands, would have means of judging which a person in England who had never removed from his study or his desk could not have. They would know the heart of missionaries. The final decision in every case would yet remain with the body of directors."

Mr. Morrison's time was now about equally divided between Canton and Macao. His wife and infant daughter resided at the latter place, and he was under the painful necessity of being separated from them for half of the year.

Mr. Elphinstone, the chief of the Company in China, offered him the situation of chaplain, with a salary attached. He did this, he said, with the object of increasing the comfort of his position, as living at Macao was very expensive. 'The offer was that Mr. Morrison should read the Church Service, but not preach. He offered to conduct full service on the Lord's day, but declined the salary. He could not accept such a position unless it enabled him to preach the Gospel of Jesus. The arrangements, therefore, were brought to an end. Fresh opposition to the Gospel was manifested at this time in Macao. The Government there was a 


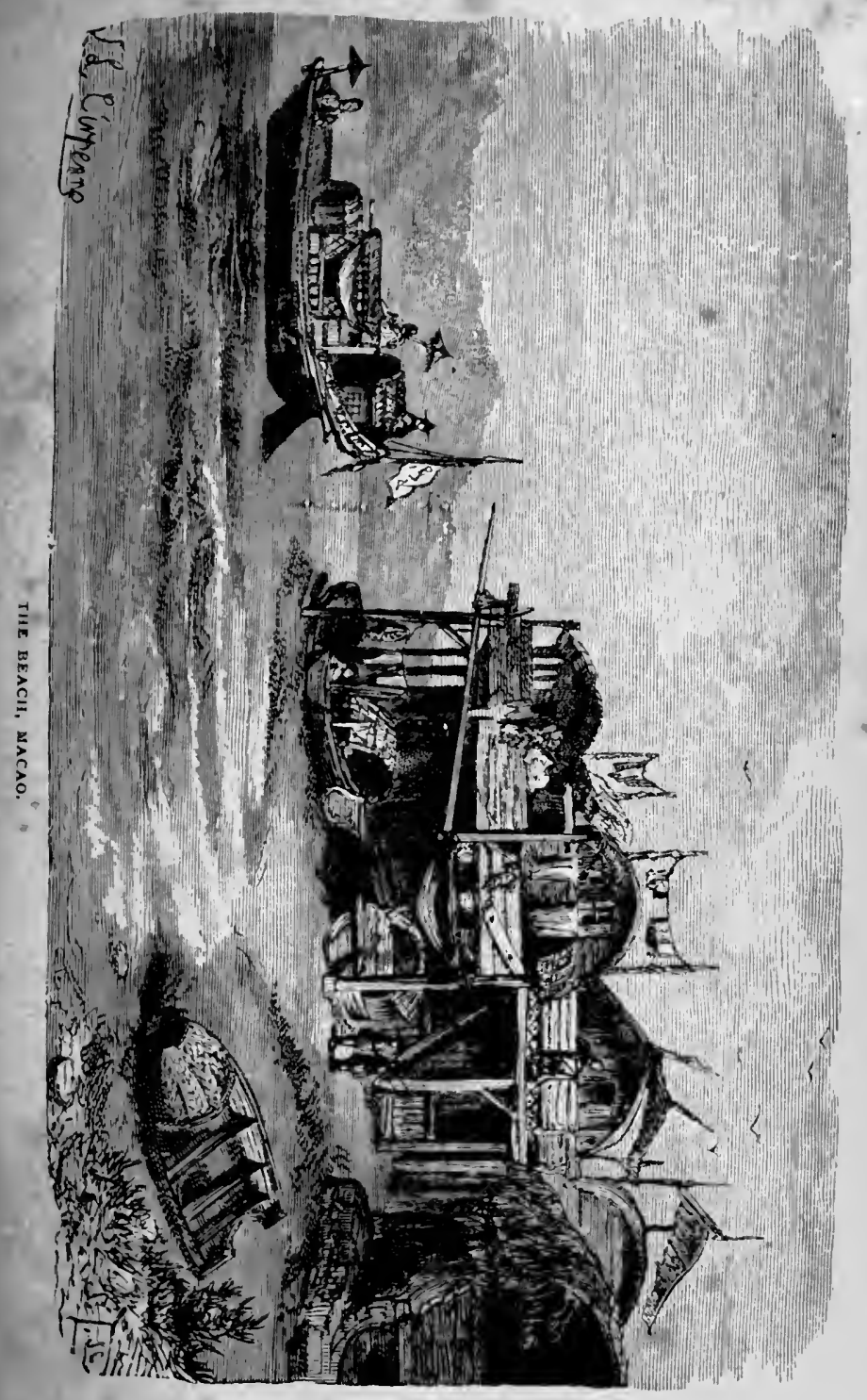


mixed one, partly Chinese, partly Portuguese. The Chinese ordered that no more Europeans should be allowed to be landed on the island to remain. The Portuguese ordered that no such persons were to be admitted except such as were connected with the European factories. Following in these directions, a proclamation was announced by the Chinese chief magistrate, prohibiting any Chinese from adopting the Christian religion.

Under Mr. Morrison's earliest entreaty, the Society in London had determined to establish a mission in Java, in which there were thirty millions of inhabitants, half a million of whom were Chinese, and amongst whom the Scriptureswhich were being so rapidly translated and printed-might be freely distributed.

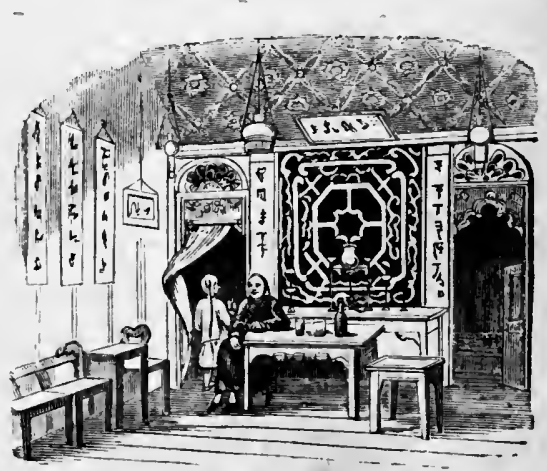




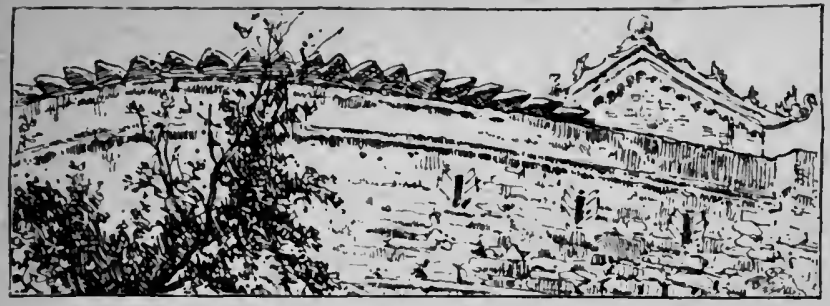

\section{CHAPTER VIII.}

\section{A FELLOW-LABOURER.}

"Ile holds no parley with uninanly fears;

Where duty bids, he confidently stecrs,

Faces a thousand dangers at her call,

And, trusting in his God, surmounts them all."

CowTER.

T $\mathrm{T}$ is impossible to adequately realise the delight of $\mathrm{Mr}$. and Mrs. Morrison when, on July 4 th, I 8 I3, being the Sabbath, and just as they were sitting down at the Lord's table, a note arrived with the news that Mr. Milne, the brother missionary long promised and expected, had arrived with his wife at Macao, A more welcome or admirable fellow-labourer never entered the mission field. It may be convenient at this point to state in a fow sentences something concerning his early days and training for the great work.

He was born in Aberdeenshire, in Scotland, in 1785 . His father died when he was six years old, and his mother gave him such education as was common to boys in humble life. Soon after his father's death he was put under the guardianship of a relative, who neglected his morals, until he became notoriously wicked, especially as a profane swearer. But he was not long to be given up to sin. In 
his early years he attended a Sabbath evening school, which was taught in the neighbourhood of his residence. Here his knowledge of evangelical truth increased, and its value was impressed upon his mind. Sometimes he walked home from the school alone, about a mile over the brow of a hill, praying all the way. At this time he began to conduct family worship in his mother's house; and he also held meetings for prayer with his sisters and other children in a barn that belonged to the premises.

When removed from his home, he was placed in a situa'ion near a very poor man who was rich in faith and holiness. He often went to his house at the hour for family prayer, and united in the worship. After reading the Scriptures, this man was in the habit of expounding them for the instruction of the children, and his remarks deeply interested young Milne, and greatly helped to increase his affection for the Bible. Religion was presented to him in this household in such an attractive manner, that he was led to make a full and deliberate choice of Christ as his Saviour and Friend. The family in which he lived were not only irreligious themselves, but derided the youth for his piety, making his position most uncomfortable. The only place obtainable for meditation or prayer was a sheep-cote where the flock was kept in the winter, and here, surrounded by animals, he often knelt in prayer, on a piece of turf kept for that purpose. Many hours were thus spent on winter evenings, and here he often had sweet refreshment while the members of his master's household were contriving some fresh mortification for his spirit. He read some books at this time which greatly influenced him, especially "The. Cloud of Witnesses," and Boston's "Fourfold State." He became a member of the Congregational Church at Huntly, saying on his reception, "What a wonder am I to myself! Surely the Lord hath magnified His grace to me above any of the fallen race." Hours were spent by him every day in prayer for the conversion of the world to Christ; but it was not till 
he was twenty years old that he consecrated himself for mission work, and then he had many obstacles in his path. He spent five years in hard labour to make provision for his widowed mother and sisters; and when this object was accomplished he at once offered himself to the local committee of the London Missionary Society.

On his appearance before the Committee at Aberdeen, he seemed so rustic and unpromising that a cautious member took Dr. Philip aside, and expressed his doubts whether he had the necessary qualifications for a missionary, but he added that he would have no objection to recommend him as a servant to a missionary, provided he would be willing to engage in that capacity. "At the suggestion of my worthy friend," says Dr. Philip, "I desired to speak with him alone. Having stated to him the objection which had been made, and asked him if he would consent to the proposal, he replied without hesitation, and with the most significant and animated expression of countenance, "Yes, sir, most certainly; I am willing to be anything, so that I am in the work. To be a hewer of wood and a drawer of water is too great an honour for me when the Lord's House is building." "

He was then accepted by the Committee, and directed to Gosport, where he went through a regular course of training under I)r. Bogue. He says: "I began with scarcely any hope of success, but resolved that failure should not be for want of application. His subsequent course proved that he had both capacity and perseverance to enable him to leave a permanent landmark in the cliffs of time. He passed through his college course with great success. In July i $8 \mathbf{2} 2$ he was ordained to the work of the ministry, and dedicated to the service of Christ among the heathen. Shortly afterwards he married Miss Cowie, daughter of Charles Cowic, Esq., of Aberdeen. She was an eminently pious and prudent woman, and contributed greatly to his happiness and usefulness until her death, in ISI9. 
A month after his ordination they embarked at Portsmouth for China, and having touched at the Cape of Good Hope and the Isle of France, were warmly welcomed at Macao by Mr. and Mrs. Morrison. Mr. Morrison says:

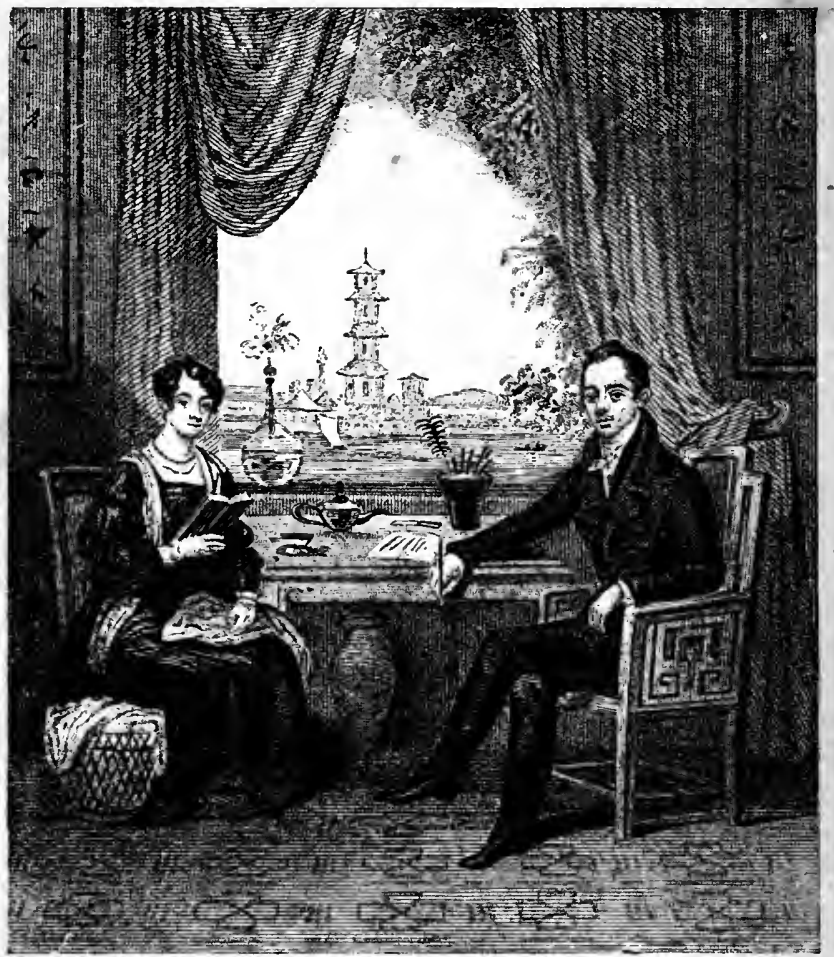

MR. AND MRS. MILNE.

"I went down immediately to the tavern, about ten minutes' walk from our residence. On the way I lifted up my heart in prayer to God for His blessing and direction in all things. After we recognised each other, Mrs. Milne was sent home in a palanquin, and brother Milne and I called on the 
Minister and Governor, according to the custom of the place. They both received us with civility, and offered no objection to Mr. Milne at the moment.

"The next day I called on Mr. — to state that Mr. Milne had arrived, and asked his permission to allow him to remain. He demurred for some time, alleging that no person is allowed to come here-that the object of the English here had been fully stated to be purely mercantile -that the Chinese would disallow a religicus establishment, etc. He finally consented to do nothing actively. He would consider Mr. Milne a Chinese student."

The following prayer was entered in Mr. Morrison's journal: "Thus far (blessed be the great Disposer of events) the door has been opened. Oh that the Lord's servant may be spared in health, may soon acquire the language of the heathen, and be a faithful missionary of Jesus Christ!"

When the news circulated as to Mr. and Mrs. Milne's arrival, there was excitement both amongst the English and Portuguese. Hostility at once broke forth. The Roman Catholics appealed to the Governor, the Senate met, and it was decreed in full council "that Mr. Milne should not remain." In a few days a messenger from the Governor waited on Mr. Morrison with a message for him to go up to his house. When the missionary arrived, he was coolly received. The following conversation took place: "Does the Padre," said the Governor, "at your house purpose to remain here?" "Please, your Excellency, for the present, if you please," was the answer. "It is," said the Governor, "absolutely impossible ; he must leave in eight days." Mr. Morrison entreated him on one knee not to persist in this order, but to at least extend the term. The Governor said his orders were not to allow people to remain, that the Senate and the Roman Catholic Bishop had required him to act, that he had been appealed to against Mr. Morrison for publishing books in Chinese at Macao, but from motives of friendship he had forborne to act. Finally, he extended 
his permission for Mr. Milne to remain eighteen days. All further efforts in the same direction proved fruitless.

On July zoth Mr. Milne left Macao in a Chinese fast boat. He couid get no legal conveyance, and therefore had to proceed by stealth to Whampoa, thence taking ship to Canton. 'This treatment on the part of the authorities at Macao grcatly grieved Mr. Morrison, the more so as an intimation was given him that he ought to surrender his mission work and devote himself exclusively to the affairs of the Company. But they had not properly understood the man if they thought such a thing possible. Mr. Morrison was missionary first and essentially; he was a servant of the East India Company for its convenience and his own.

A few days later he went to Canton, where he found Mr. Milne well, busily engaged with his studies, but in very uncomfortable quarters. Thence he returned to Macao; and on September 3oth again arrived at Canton, having just finished the translation of the New Testament in Chinese. He now devoted himself increasingly to the Anglo-Chinese Dictionary, which severely taxed his powers and resources. In the midst of these labours, his position was rendered the more trying by the death of Mr. Roberts, the chief of the English Factory, who had proved a warm friend to him since his arrival in China.

The year 1814 opened with fresh opposition from the Chinese authorities. The Viceroy had reported Mr. Morrison to the Government as becoming fully acquainted with the language and customs of the country, and as being the translator of all English official documents which were received by the Government. The Government sent a document denouncing in harsh terms all who were concerned in imparting to him any help in the composition of official despatches, and the Viceroy issued an order for their apprehension. Kō Sëeng-săng and his son were therefore dismissed and sent to a place of safety. But, on the other hand, the New Testament was printed and 
ready for circulation, so that there was the prospect of good being done through its finding a way into the homes of many of the people. Two thousand copies were first printed, which were taken from wooden blocks. From these blocks one hundred thousand copies might have been printed without material damage being done to them. Mr. Morrison also issued simultaneously ten thousand copies of a tract containing an outline of the Christian system, and five thousand copies of a Catechism.

It was soon found that Mr. Milne would not be permitted to remain at Canton, and that he must look out for a residence elsewhere. Mr. Morrison therefore addressed to him an earnest letter as to their future steps. He says: "To the attainment of our object under the blessing of God a free and unshackled residence in the heart of China would be the most desirable, but that is at present impracticable. Next to that a residence in the suburbs of Canton or at Macao may seem desirable. Were we at liberty to exercise our missionary functions it would be so, but confined to a room and debarred from free intercourse with the natives, it is not so desirable for the seat of the mission as may at first sight appear. . . As a residence is denied to us here it is ours to fix the Jerusalem of our mission elsewhere. We want a headquarters at which to meet and consult, from which to commission persons to go out on every hand, a home to which to retire in case of sickness or declining years. We want, if it be in the course of I)ivine Providence, a school for the instruction of Native and European youth; for the reception and initiation of young missionaries from Europe. It is yours to seck for and found this important station. Perhaps, at Malacca, or Java, an open door may be found."

It was therefore settled that Mr. Milne should go through the chief Chinese settlements in the Malay Archipelago with the following objects in view : first, to circulate the New Testament and tracts just published amongst the 
tens of thousands of Chinese who lived in those islands; 色 地 secondly, to seek a quiet and peaceful

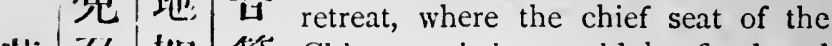
橆 倭 如等 Chinese mission could be fixed and 威 传: 於 父 its labours pursued without the harass國傎 於 全 ing persecution of a bigoted and ex考 與 天 在 clusive Government; thirdly, to gather 權我琵灭

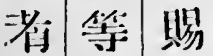
灭者我 桨地等 up such information as to populations, etc., as might afford good grounds for 者 $j$ deciding as to the best means of pur原 suing mission work among them; and 息 fourthly, to ascertain what opportuni调 ties there were of printing a volume 不 of dialogues in Chinese and English 7 to assist other agents in the acquisi成 tion of the language. With the purIII poses of his voyage thus defined, $\mathrm{Mr}$. Milne proceeded to visit Java, Malacca, Penang, and other places.

During Mr. Milne's absence Mr. Morrison proceeded with his work of 世誘 糧 王 世惑 否 䧊 琵丁了我至 心救焦诋 硕 我債 正等如奉 昆出|我行 响等於会 THE LORD'S PRAYER IN CHINESE. publication. He issued in Chinese a pamphlet in which he traced a concise outline of Old Testament history, chiefly relating to the Creation, Deluge, Exodus, giving of the Law, and principal events of the kingdom of Israel. $\mathrm{He}$ also translated and printed a selection of hymns to be used in Divine worship; consisting mainly of psalms rendered from the Scotch version, and the hymns of Watts, Cowper, and Newton, in most general use at home.

So many copies of the New Testament had been required by Mr. Milne for distribution on his travels that a new 
edition was qu.ickly called for. The book had been printed in large octaro form, and Mr. Morrison decided to print it in duodecims, as being more generally convenient. Besides, in the critical condition of the Mission, it was of importance to have two sets of llocks, to be kept in different places, so that if one fell into the hands of opponents the other might be in reserve. New wood-blocks were therefore prepared, at a cost of five hundred Spanish dollars, * besides half-a-dollar each copy for printing off. But this cost was greatly increased by the dishonest advantage afterwards taken of Mr. Morrison by the Chinese.

The Anglo-Chinese Dictionary now approa hed completion. Immense labour had been spent upon it, and its publication became a matter of extreme anxiety to Mr. Morrison. It would have been comparatively useless to have remained in manuscript. The expense of transeribing it for the use of other missionaries or the employe's of the Company would have been immense. 'To copy the Dictionary prepared previously by Romish missionaries had cost two hundred Spanish dollars, and it was only one-sixth the size of this prepared by Mr. Morrison. The expenses incurred already in gathering up materials for its composition had been very great, and the cost of its publication was alike beyond the means of the author and of the Missionary Society. It was, therefore, with thankfulness and a sense of gracious relief that Mr. Morrison, after much negotiation, obtained from the Company a promise to print it at its expense. At once the Select Committee made arrangements, and shortly afterwards Mr. P. P. Thoms was sent out from England to China, with presses, types, and all requisites for the work, to superintend its publication.

The translation of the Old 'Testament was then in progress, and Mr. Morrison finished the Book of Genesis, which was printed separately at the beginning of $1 \mathrm{~S}_{\mathrm{I}} 5$.

In the meantime Mr. Milne returned from his travels.

* Then valued at five shillings per doliar. 
$\mathrm{He}$ had visited Java, and received much encouragement and help in his enterprise from the enlightened and truly Christian Governor, Sir T. Stamford Raffles. After visiting other places he called at Malacca, and was received by Colonel Farquhar, the Resident and Commandant, with great cordiality. This gentleman showed much interest in the project of the missionaries, and proved a warm friend to them in their future operations. On Mr. Milne's return to Canton, it was decided between Mr. Morrison and himself that Malacca should be adopted as his future residence, and as the base of a new mission. The reasons for this choice were several and very weighty. Malacca was near to China, and there was frequent and easy intercourse between it and all the islands in the Eastern Archipelago, where the Chinese resided in large numbers; it lay convenient to Cochin-China, Siam, and Penang; it was en route between India and Canton, and ships sailing, between these places frequently called there. No other place presented such advantages for intercourse and transmission of books, etc. The climate was healthy, and as a mission station it would be a desirable residence for any agents who were ill or in failing health. Then it was a quiet place, the authorities were friendly, Colonel Farquhar cordially so, and here could be established a missionary settlement which should embrace the various and comprehensive scheme which had been seething in Mr. Morrison's soul for many months. A full report of Mr. Milne's expedition, and the suggestions "based upon it, were drawn up and transmitted to the Board of Directors in London.

On April $17^{\text {th }}$ he had the happiness of having a son born to him, whom he baptised on May Ist, in the name of John Robert. His little daughter Rebecca was now about twenty months old. They were both dedicated prayerfully to God's service, and both were permitted to render service to the cause of missions in China.

The year 1814 brought to Mr. Morrison what was the 
greatest joy he had hitherto experienced in his arduous work. For seven years he had hoped, prayed, scattered the seed of the kingdom, yearning that it might fall into good ground and bear fruit; but time seemed to pass by cnly to try his faith and patience more screrely. But at length he was to be refreshed by having one convert to his prolonged ministry. This was Tsae-Ako, one of his early teachers, and brother of A-Hëen, still employed by him, who now made application for baptism, giving the following confession of faith :-

"Jesus making atonement for us is the blessed sound. Language and thought are both inadequate to exhaust the gracious and admirable goodness of the intention of Jesus. I now believe in Jesus, and rely on His merits to obtain the remission of sin. I have sins and defects, and without faith in Jesus for the remission of sins should be eternally miserable. Now that we have heard of the forgiveness of sins through Jesus, we ought, with all our hearts, to rely on His merits. He who does not do so is not a good man. I by no means rely on my own goodness. When I reflect and question myself, I perceive that from childhood until now I have had no strength, no merit, no learning. 'Till this, my twenty-screnth year, I have done nothing to answer to the goodness of God in giving me existence in this world as a human being. I have not recompensed the kindness of my friends, my parents, my relations. Shall I repine? Shall I hope in my own good decds? I entirely call upon God the Father, and rely upon God for the remission of sins; I also call upon Ged to confer upon me the Holy Spirit."

The account given by Mr. Morrison of this first convert to Christ by l'rotestant missions is interesting: "Ako lost his father when he was sixteen years of age. When he was twenty-one, he came to my house and heard me talk of Jesus, but says he did not understand well what I meant. That was my first year in China. Three years after, when 
I could speak better and could write, he understood better; and being employed by his brother in superintending the New Testament for the press, he says that he began to see that the merits of Jesus were able to save all men in all ages and nations, and hence he listened to and believed in Him.

"His natural temper is not good. He often disagreed with his brother and other domestics, and I thought it better that he should retire from my service. He, however, continued, whenever he was within a few miles, to come to worship on the Sabbath day. He prayed earnestly morning and evening, and read the Decalogue as contained in the Catechism. He says that from the Decalogue and instruction of friends he saw his great and manifold errors, that his nature was wrong, that he had been unjust, and that he had not fulfilled his duty to his friends or brothers, or other men. His knowledge, of course, is very limited, and his views perhaps obscure; but I hope that his faith in Jesus is sincere. I took for my guide what Philip said to the eunuch-' If thou believest with all thine heart, thou mayest be baptised.' Oh that at the great day he may prove to be a brand plucked from the burning! May God be glorified in his eternal salvation!

"Hc writes a tolerably good hand. His father was a man of some property, which he lost by the wreck of a junk in the China seas returning from Batavia. TsaeAko, when at school, was often unwell, and did not make so much progress as his brother, A-Hëen, who is with me. A-Hëen is mild and judicious, but is, I fear, in his heart opposed to the Gospel. His attendance to preaching on the Lord's day is also constant. But insincerity and want of truth are vices which cling to the Chinese character."

Tsae-Ako had long been preparing for Christian discipleship. A slow, gradual work of grace had been proceeding in his heart, and he had given many proofs of his deep sincerity. Mr. Morrison, with his usual caution, had done 
nothing to hasten the final step, save to pray for him and to instruct him carefully in I)ivine things. It was with much confidence, therefore, that his confession of faith was received, and he was baptised into the Church of Jesus.

In his journal, under date July I 6 th, I8 14 , Mr. Morrison thus recorded the baptism :-

"At a spring of water issuing from the foot of a lofty hill by the seaside, away from human observation, I baptised, in the name of the Father, Son, and Holy Spirit, the person whose name and character have been given above. Oh that the Lord may cleanse him from all sin by the blood of Jesus, and purify his heart by the influences of the Holy Spirit! May he be the firstfruits of a great harvest-one of millions who shall come and be saved."

Tsae-Ako adhered to his profession of the Gospel until his death, which took place from consumption in $18 \mathrm{I} 9$. Mr. Morrison was not with him at his leath; but he never doubted as to his faith in the Lord Jesus at the last moment.

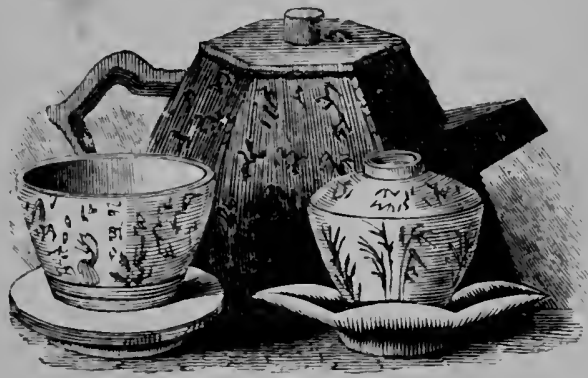




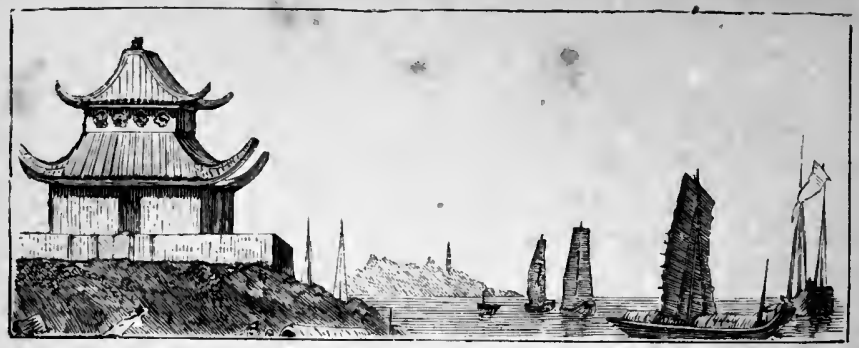

\section{CHAPTER IX.}

VISIT TO PEKIN.-COLLEGE AT MALACCA.

"Every great and commanding movement in the world is the triumph of enthusiasm."-EMERSON.

THE apprehensions which Mr. Morrison had felt as to the firmness of his position were fully justified by the reception of a letter from the Select Committee of the East India Company, dated October 14 th, I 8 I 5 , which contained the following paragraphs:-

"We feel it necessary to acquaint you that the Hon. Court of Directors, having been informed that you have printed and published in China the New Testament, together with several tracts translated into the Chinese language, and having further understood that the circulation of these translations has been effected in defiance of an edict of the Emperor of China, rendering the publisher of such works liable to capital punishment, are apprehensive that serious mischief may possibly arise to the British trade in China from these translations, and have in consequence directed that your present connection with the Honourabie Company should be discontinued. The Honourable Court remark at the same time that they nevertheless entertain a very high respect for your talents, conduct, and character, and are fully sensible of the benefits derived from your 
services; in consideration of which they have directed us to present you with four thousand dollars on the occasion of carrying the orders into effect.

"Notwithstancling the tenour of these orders, which we have implicitly communicated to you, we are under so strong an impression of the importance of your services to the affairs of our honourable employers, and so well assured, from our personal knowledge and past experience of your prudence and discretion in forbearing to place yourself in a situation which may be calculated to implicate the national interests through your connection with the Factory, that we have resolved to postpone giving effect to any part of the above instructions until we receive further orders upon the subject."

Explanation and vindication on Mr. Morrison's part were offered by him in a voluminous correspondence, in which it became apparent that the local officials of the Company were loath to carry out the decision of the Chief Board; and in a few weeks such complications arose between the Chinese Government and the Company, that an embassy, headed by Lord Amherst as Ambassador Extraordinary, was despatched from England to the Court at Pekin, to accommodate and arrange the matters in dispute. Mr. Morrison's services as secretary and translator to such an embassy could not be dispensed with, and he was requested to accompany the Ambassador to Pekin.

For a considerable time Mrs. Morrison's health had caused her husband and friends much anxiety, and her medical adviser strongly urged that she should try a sea voyage and change of climate as means to benefit her. Her husband's presence in China at the particular juncture of circumstances was deemed too insportant to be dispensed with, and therefore without him, but with her two children, Mrs. Morrison embarked for England on January 2 Ist, 1815 .

One more trial was in store. for Mr. Morrison during 
this year. The spirit of-religious intolerance was so fully aroused, that the type cutters engaged in preparing the blocks for the Dictionary were arrested; and, in alarm, the blocks which had just been completed for the fresh edition of the New Testament and the Book of Genesis, were destroyed by the printers to prevent discovery. This was a deep disappointment to the indefatigable and dauntless labourer; but he at once took reart of grace, and set about the preparation of new types. Very soon the intelligence reached him that the British and Foreign Bible Society had made a grant, as liberal as it was timely, of one thousand pounds, which enabled him to have blocks cut, not only for the duodecimo edition of the Testament, but for the Book of Psalms, the translation of which was just complete. In writing to inform him of this grant, the Rev. J. Owen, Secretary of the Bible Society, said :-

"Should your translation be, on the whole, a faithful image of the sacred original, and the understanding of the Chinese be opened by its Divine Author to understand and admire it, what an honour will be conferred on your labours, and what blessing will you have been called upon to inherit! Desirous of participating in that honour and that blessing, the British and Foreign Bible Society has furnished you from time to tine with contributions of pecuniary aid, and you may assure yourself that it will continue to assist you in the prosecution of an undertaking so congenial with the object of its appointment and the wishes of its conductors."

It may be mentioned here, that a short time before this an English merchant had died in China, and had left Mr. Morrison one thousand pounds for the purposes of his Mission, which sum had been devoted to the printing of the New 'Testament and other Christian books.

Lord Amherst and his attendant officials arrived at Canton in the Alceste on July 1 3 th, 1816, and took on board Sir George Staunton ind lir. Morrison; then the vessel pro- 
ceeded on its way till, on July 28 th, it anchored at the mouth of the River Peiho. On August $\mathbf{r}_{3}$ th they were entertained in the city of Tien-tsin at a great banquet, given by two Imperial Commissioners in the name of the Emperor. Mr. Morrison gives an interesting description of the reception and entertainment. The Imperial Commissioners and the English Ambassadors and Commissioners sat on very low cushions, raised about six inches from the ground, while the suite of the Emperor sat on the ground, on which a red cloth had been placed.

On August 2oth they all arrived at Tung-chow, a day's journey from Pekin. Here eight days were spent in disputing a question of ceremony. It was required of the English Ambassador that, on being brought before the Emperor, he should perform what is called in China "THE Creremony," or San Kzeei, Keze Kow, rendered in English, "Three kneelings and nine knocks of the head." The mode of performing is, that the person introduced to the Emperor kneels on the ground, places his hands when bowing forwards on the floor, and strikes his forehead against the earth thrice; then the person rises, and, again kneeling down, repeats the performance; and then, rising once more, repeats the whole a third time. Thus it is the Chinese worship their gods-some by three knocks, others by six, and others by nine, according to the veneration in which they are held. Lord Amherst was not very likely to go through such a foolish and degrading ceremony, and, after prolonged disputes, the Chinese noblemen professed to waive the requirement. On the $29^{\text {th }}$ the company arrived at the Imperial Palace. The hour appointed by the Emperor for giving audience had arrived. The Ambassador and his suite had travelled all night, were unwashed and unrefreshed, and ill-prepared for the interview with royalty. His lordship therefore pleaded with the nobleman who received him, that the fatigues of the night had been so great that he must beg his Majesty to defer the reception 


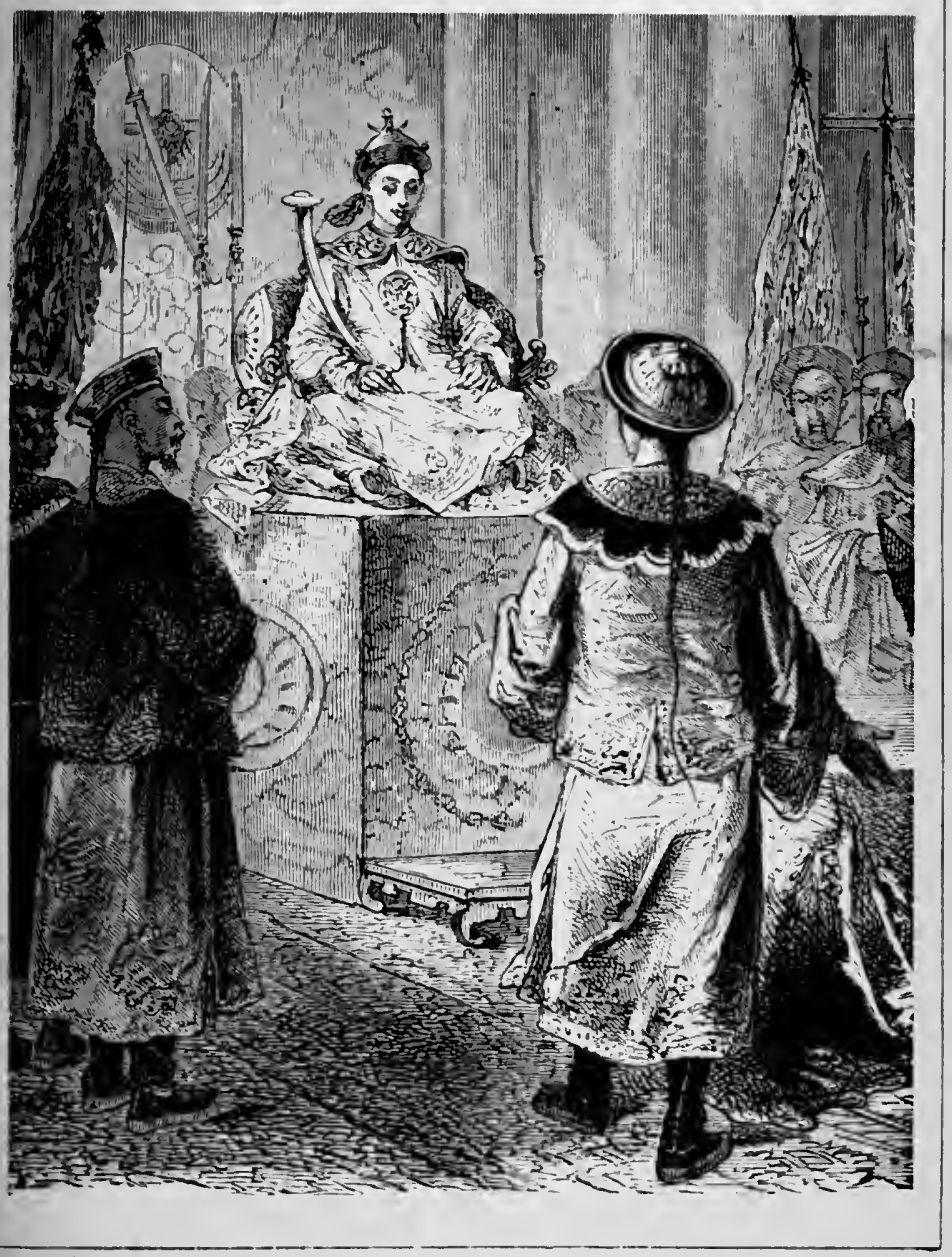

CHINESE EMPEROR. 
until the following morning. To effect this, the messengers went into the Emperor and told him the Ambassador was so ill that he could not stir a step. The Emperor graciously. permitted him to retire to his lodging, and sent his physician to attend him. The physician did not find Lord Amherst ill, and no doubt made a representation to the Emperor that did untold harm. His Majesty thought he had been imposed upon. A special meeting of the Cabinet was called. No one dared to explain the real facts of the case, and an order was issued that the Ambassador should depart immediately. The order was obeyed. The whole party left Pekin the same afternoon, and, after incurring a journey of fifty thousand miles there and back, Lord Amberst had to report a result of nothing. The Emperor afterwards discovered the real state of the case, and degraded the Duke, who was brother to the Empress, from all the high offices which he held. Three other persons were also degraded, and an edict was issued in which the Emperor lamented that his courtiers could be so selfishly indifferent to the public welfare. He reproached the Duke's friends, that although they professed great attachment to him, smiling and fawning upon him, yet when they saw him perplexed by misrepresentation, they would not tell him the true state of affairs, but simply said, "It is not nıy business." "Alas!" he said, "on what a dangerous rocky eminence does a statesman stand. If you had no regard for the Duke, had you none for your country?" The Emperor's false pride would not pernit him to explain or reverse his treatment of the Ambassador, but he ordered his officers to treat him everywhere with politeness, and sent three presents to the King of England. He also accepted three from the Ambassador. With the same childish idea of his pre-eminence over all other potentates, he called his articles sent to the king a " donation," but those received he called "tribute."

Although the object of the Embassy had thus failed, the journey gave Mr. Morrison a few months of relaxation which 
his health greatly craved. He was able to extend his knowledge of the country and the people, and especially he was able to gather up some knowledge of the various dialects of the provinces through which he passed, which was of great service to him afterwards.

He and the distinguished party returned to Canton through the provinces of Chilhi and Shantung, crossing the Yellow River and the Great Canal. They were struck with the graceful pagodas and beautiful temples which ornamented the scenes they passed through, but the moral and religious phenomena most interested Mr. Morrison. He met and conversed with a Mohammedan gentleman, who gave him full details of the peculiarities of his religion, and its position in China. He was surprised to find that, whereas P'rotestant Christianity was not allowed a foothold, Mohammedans were allowed the exercise of their religion, were admitted into the service of the Government, and that they existed in some provinces in large numbers. He also found that in Honan there were a number of families called "Teaou Kin Keaou," or the sect which plucks out the sinews from the meat they eat. They had a temple of worship, and they kept the seventh day as a Sabbath. Some time after Dr. Miorrison was dead a deputation was sent by the Bishop of Victoria to visit these people. They were found to be Jews, who had lost the memory of their own history. They had a number of Hebrew books, which none of them could read, but which, when examined, were found to be portions of the Old Testament, some of them beautifully written on white sheepskin, cut and sewn together, about twenty yards long, and rolled on sticks. Other groups of Jews have been discovered in various provinces of China, all giving emphasis to the Divine prediction concerning them as a "nation scattered and peeled, and a people meted out and trodden under foot."

In Shantung the party passed near to the birthplace of Confucius, and on the Po-Yang Lake they found a college 
at which Choo-foo-tsze, the most esteemed commentator on the "Four Books" of the great sage, taught about six hundred years before. The college was at the top of a glen, through which a sparkling brook sang its quiet tune. At the top of the glen a huge mountain lifted its black and frowning sumnit, as though to shelter the "College of the White Stag Valley" from the bitter blast. Here Choo-footsze taught, and they were shown the rock on which he angled, and a tree still bearing flowers which he planted with his own hand, to pluck the leaves of which was strictly forbidden.

In crossing the dividing line between the provinces Kiang-si and Canton, they passed through a deep mountain cutting made through the solid rock by the liberality of a retired statesman, a thousand years ago. His image stands in an adjoining temple, and divine honours were offered to it. The embassy arrived at Canton after an absence of six months. During Mr. Morrison's absence a volume of dialogues in Chinese and English, which he had prepared, had been carried through the press at Canton, under the superintendence of a gentleman in the British Factory.

Mr. Milne and his family had left China and taken up their residence in Malacca, to carry out the great scheme so long a daydream with Mr. Morrison, but which was now about to become in great part a reality by the agency of his faithful fellow-labourer. Mr. Milne had collected Chinese books, printing paper, and other needful materials, secured a teacher of the language, engaged workmen, and sailed on April I 7 th, 1815, for his new home. On the voyage his family was increased by twins; and, after thirty-five days' sail, he reached his destination, and was cordially received by Major Farquhar, who proved himself to be a friend indeed.

The scheme indicated previously in regard to the mission at Malacca had been carefully formulated by Messrs. Morrison and Milne, presented to the London Missionary Society, and fully approved and sanctioned by it. The 


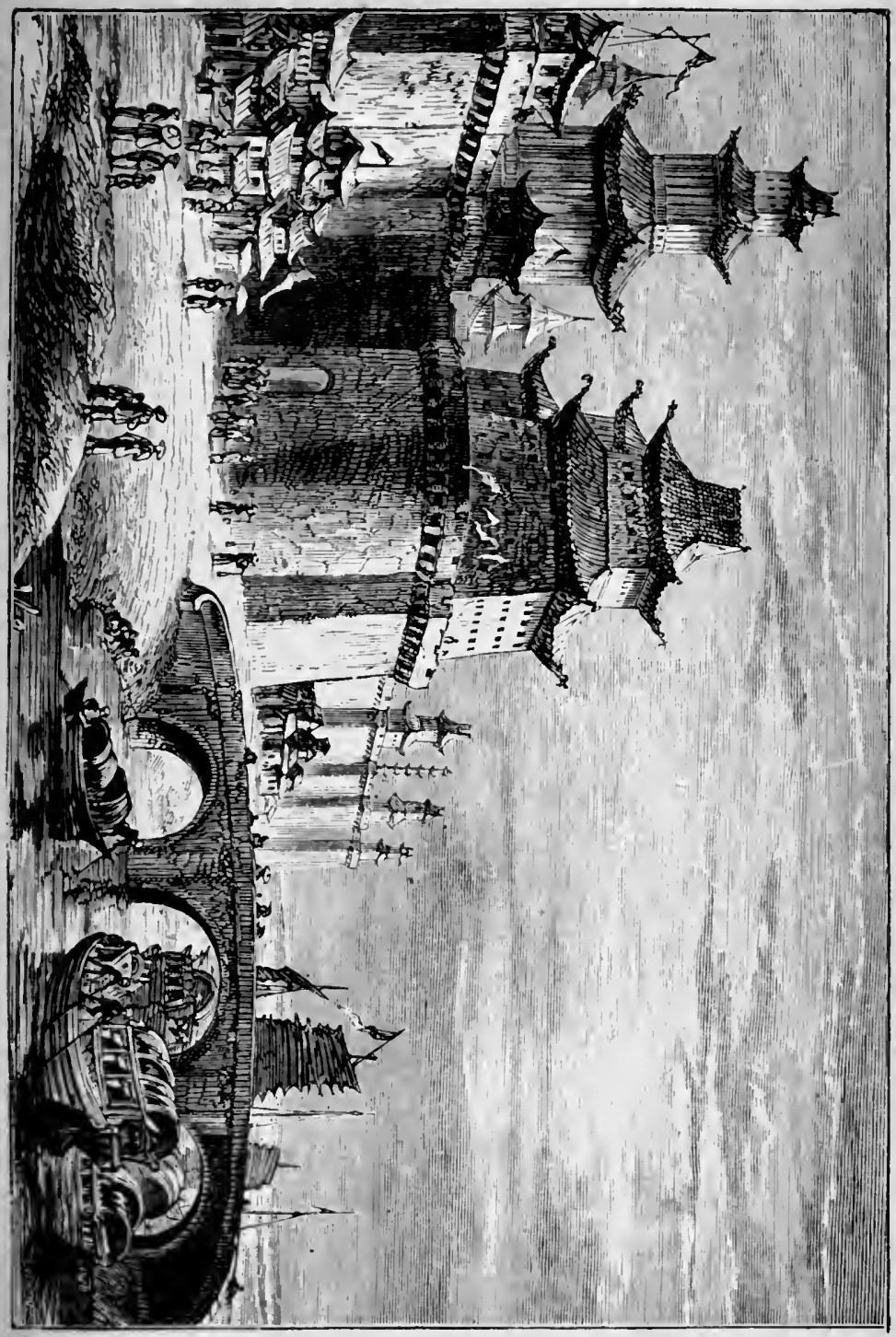


programme was an ambitious one, and, whilst successful to a degree which fully justified the outlay of its founders, it did not realise all that their faith and enterprise merited. According to the plan sketched out, a portion of land was to be purchased, on which buildings could be erected suitable for the purposes contemplated and intended. A free school was to be established as a preparation for a more advanced seminary, in which native ministers might be trained and educated. A monthly magazine in Chinese was to be issued. A printing-press was to be set up and kept at work, for the purpose of issuing the Scriptures in Chinese, and for the diffusion of Christian literature generally. An English periodical was to be issued also, with the view of promoting unity and co-operation among missionary societies in the East. Divine services were to be held, and places of worship to be erected as quickly as practicable. "The whole scheme was to be called "The Ultra-Ganges Mission," as denominating the scene or area of the enterprise.

Mr. Milne quickly began the attempt to realise the scheme. A small house in the British compound, which had formerly been used as a stable, was fitted up as a school. Notices in Chinese were posted up in the town, announcing the commencement of a school for the children of the poor. Great unwillingness was at first shown by the people to send their children, and when the school opened on August $5^{\text {th }}$ only five scholars had been obtained; but, by sedulous effort and wise caution, the number increased, until by the end of the first year the number in daily attendance was fourteen, who received the ordinary elements of Chinese education. By-and-by the Catechism prepared by Mr. Morrison was introduced, and the children were familiarised with the leading words of religious character, such as God, Creation, Soul, Death, and many others. Then the teacher and children were drawn to attend Divine worship. Great prudence was required here 
First, a few domestics brought from Canton were drawn to attend, and then the school teacher and his pupils were induced to follow them. Thus very slowly had Mr. Milne to take step after step towards the attainment of his great object. A small church of Dutch Christians in Malacca was at this time without a pastor, and they invited Mr. Milne to occupy the vacant place. This he declined, on the ground that he was commissioned for another purpose; but he undertook to conduct Divine service for their benefit once a week. For about a year no land was obtained for the erection of the meditated buildings; but at the beginning of 1816 Mr. Milne obtained a grant of land from the English Governor at Penang, subject to approval from the Dutch authorities. This was a considerable distance from the town, and not suitable for the purposes of the Mission. It was, therefore, exchanged for a smaller piece near the city gates, a sum of about two hundred pounds being paid as a further recompense to the vendor. Thus was a site obtained in a most eligible situation. It has been mentioned that workmen as printers had accompanied Mr. Milne from China. He now procured a printing-press, founts of English and Malay types, and all necessary apparatus for setting to work. In order to keep his men employed, he printed an edition in English of Doddridge's "Rise and Progress of Religion in the Soul," and Bogue's " Essays on the 'lruth of the Christian Religion." These were sold or distributed amongst the English residents and adventurers in China, India, and in the wide Archipelago of the East.

On Mr. Morrison resuming his work at Canton, he was quickly tried by fresh difficulties which beset him. A quarrel broke out among his workmen at the press; one of whom, to revenge himself on others, took a sheet of the Dictionary to the Tso-tang, a district magistrate. This official was only too glad of an occurrence which seemed to afford an opportunity of extorting money, and sent his police runners to seize the printing materials, and the 
natives who were engaged in the illegal task of assisting forcigners to print the Chinese language. Sir Theophilus Metcalf, the English chief of the Factory, interfered with great firmness, and prevented the presses and types being impounded. The Viceroy of Canton issued prompt orders that no natives should aid foreigners in printing the Chinese characters; the names of Mr. Morrison's teachers and transcribers were rccorded for arrest; Kō-Sëen-săng absconded, while Sam-Tak, A-Fo, and A-Hëen were in great apprehension. The result was that Portuguese workmen had to be instructed to cut the Chinese characters on woodblocks for the printing of the Dictionary.

Besides his incessant labours on the Dictionary, usually occupying six or eight hours a day, Mr. Morrison translated and published the morning and evening prayers as they stand in the Book of Common Prayer, also "Horæ Sinicæ," a series of translations from Chinese classics, and a Chinese Primer, all of which, with other works already recorded, prove a zeal and diligence of application that must have tried thest patient mind and tested the strongest constitution. The progress the translation of the Bible was making is indicated in the following letter to the Bible Society, under date November 24th, I8I 7 :-

"During the ensuing year Mr. Milne and I hope to finish a translation of the whole Bible. He has completed Deuteronomy and Joshua. The Book of Genesis has been printed some time. I have made a first draught of the Book of Exodus and the Book of Ruth. The Psalms I have finished, and they are now in the press. The Book of Isaiah is about onc-half translated. Several type-cutters are engaged to go down to Malacca for the purpose of printing Jeuteronomy, Joshua, and an edition of the Psalms in duodecimo; that which I am perfecting here is smaller than our duodecimo New Testament."

A letter from America at this time informed $\mathrm{Mr}$. Morrison that a young Chinaman, about twenty-six years 
of age, from Macao, who had settled in New York, had been led, through the reading of the Chinese New Testament, to profess faith in Christ, and was manifesting the utmost earnestness and consistency. These tidings, amidst the dry, monotonous grind of translation work, were peculiarly refreshing to his soul.

Mr. Morrison's labours now began to excite attention and interest in all parts of Great Britain, and also in many parts of Furope and America. He received letters from some of the most learned professors in Germany and France, most warmly recognising his eminent attainments and services. Dr. Vater, Professor of Konigsherg University, and M. Remusat, Professor of Chinese, etc., in the Royal College of France, one of the most erudite men in Europe, with others, frankly and cordially congratulated him upon the thorough and varied knowledge he had gained of Chinese language and literature, and the firm foundation he was laying for his successors. He was unanimously and gratuitously created Doctor of Divinity by the Senatus Academicus of the University of Glasgow, as a recognition of the great value of his labours as a philologist and a Christian teacher.

He had now been ten years at work in the far-off landyears that had been devoted to intense and grinding labour, years of prolonged strain and trial by reason of the annoyance and persecution of Chinese officials and the scarcely concealed dislike of many of the English merchants, years of severe and depressing disappointment on account of the stubborn and dogged indifference to Gospel truth manifested by the natives. The sterling qualities of Mr. Morrison's nature had all been brought into active and energetic exercise by the pressing exigencies of his position, and they had admirably enabled him to grapple with those exigencies. Not that he had been uncheered in his labours in the interim. Providence had, on several trying occasions, interfered in his behalf in a special manner, enabling him 
to maintain a foothold in the land, giving him a position by which he might prosecute evangelistic work undisturbed by the official arm, and affording throughout all his labours such a fresh, clear sense of peace and comfort that he was maintained in hope and courage, and was prepared to labour on, resting on the promise, "In quietness and in confidence shall be your strength." And certainly the results of those ten years were permanent material for the future. An ample knowledge of the most difficult language and the most obscure literature had been obtained. Large plant of printing-presses, types, woodblocks, and other material had been accumulated; one large edition of the New 'Testament in Chinese had been printed and circulated; another edition of nine thousand copies was nearly printed off; a Chincse grammar, a volume of translations from Chinese classics, a psalter, a book of prayers, several small publications on Christian doctrine and history, had also been issued as the result of his own application; not to speak of the Books of the Old Testament already translated, and some of them printed, awaiting the completion of the whole before passing into circulation. Besides this must be taken into account the help given to Mr. Milne in his acquisition of the language, and the establishment of the mission in Malacca. All this was accomplished, besides the invaluable services rendered by Mr. Morrison to the East India Company as its official translator and secretary.

Nor had the ten years been uiterly fruitless as to the main work of the Christian missionary-the conversion of souls to God. 'Two persons at least had given up idolatry and professed faith in Christ; one of these had been baptised, and maintained a good confession, and the other was giving promise of such growth in Christian knowledge and piety as to warrant his reception by baptism before long. 'The experiences of other pioneer Protestant missionaries had been far different to Mr. Morrison's. They had faced greater risks and dangers from savages and 
barbarians, they had passed through exciting adventures and romantic trials, but they had also been cheered and inspired by great successes; and it may be doubted whether any of them had shown greater calmness in presence of danger, heroism more grand, or determination nıre unwavering, in spite of repeated disappointments, than had been manifested by Robert Morrison during this period.

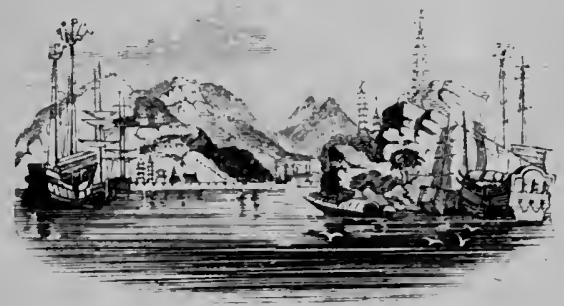




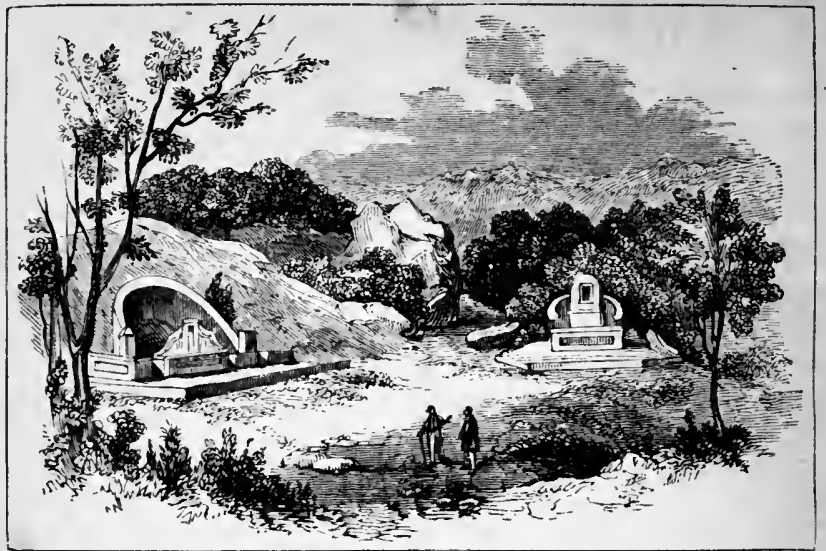

\section{CHAPTER X.}

\section{CIIINESE BIBLE COMPLETED.-DR. MILNE'S $D E A T H$.}

" God did anoint thee with His odorous oil, To wrestle, not to reign; and He assigns All thy tears over, like pure crystallines, For younger fellow-workcrs of the soil, To wear as amulets. So others shall Take patience, labour to their heart and hand, From thy hand, and thy heart, and thy brave cheer." E. B. Browning.

N November Ioth, I8I8, the foundation-stone of the Anglo-Chinese College at Malacca was laid by Colonel W. Farquhar, in the presence of the Hon. J. S. T. Thyson (the Governor), Hon. J. J. Erskine (Judge of Penang), the members of the College of Justice, and many other distinguished persons. Mr. Milne represented Dr. Morrison, and delivered a suitable address. The object was announced as the reciprocal cultivation of Chinese and European literature, and the machinery was 
to comprise a library furnished with books treating on the language, history, science, etc., of European and Oriental nations. European professors of the Chinese- language, aided by native Chinese tutors, were to impart knowledge ; a printing-press was to be made use of in divers manners, and it was also intended soon to form a botanic garden, so as to have in one focus the plants of the Eastern Archipelago. To the advantages of the institution Europeans were to be admitted, to be fitted and prepared for missionary, commercial, scientific, or official pursuits in the East, and also youths from Chinese-speaking countries, who desired to be trained for service under Europeans or in the Christian Church. Dr. Morrison contributed ore thousand pounds towards the establishment, and promised a hundred pounds a year for five years towards its maintenance. He otherwise, especially in respect of the library, contributed largely towards the College. Another gentleman gave the sum of four thousand Spanish dollars towards the building, the London Missionary Society gave five hundred pounds, and European residents in Canton five hundred pounds. One friend wrote :-

"I confess that the plan far outstrips my expectations. It is benevolent and liberal to a degree; it is extensive also, and so ought our donations therefore to be. I shall be obliged to you to draw on me at any time you like for $\mathbf{S}_{420}$ [that being equal to one hundred guineas].

"'In faith and hope the world will disagree,

But all mankind's concern is charity:

Thus God and nature linked the general frame,

And bade self-love and social be the same.'"

No words can describe the bright visions of usefulness which Dr. Morrison entertained as to the results of this institution. Malacca was to be not the Athens only, but the Jerusalem of the East. Streams of knowledge and spiritual grace were to flow from thence until the Chinese world was sanctified thereby. Malacca was one of the 
first European possessions in Asia, being captured by the Portuguese a very few years after the successful voyage of Vasco de Gama round the Cape of Good Hope. They did not do much to improve the moral condition of the natives. It was visited by Francis Xavier, who testified that the excess and number of their vices alone distinguished the Christians from the unbelievers. It was afterwards captured by the English, and it was chosen as the most convenient and promising centre for the great work Dr. Morrison had so much at heart.

The College erected was a plain substantial edifice, ninety feet in length, thirty-four in breadth, with a verandah back and front supported by pillars, one hundred and three feet long, and sixteen and a half wide. The interior was suitably arranged, on one side being the Chinese and English printing offices, schools and apartments for native masters, workmen, etc. ; on the other the residences of the governor and his assistants. The front, which faced the sea, was shaded by a row of senna trees, and the whole was surrounded by grounds which were well laid out and cultivated.

For some time there was great disappointment in the minds of the promoters, as the natives refused to send their children, until Mr. Milne was obliged to offer a small weekly payment to each child to induce its attendance. As the natives became familiarised to the presence of the College, and understood better the spirit of its conductors, they became more trustful, and the school prospered. Pupils and students were trained, during Mr. Milne's life, varying in number from twenty up to sixty at one time; and of these several were converted and became consistent Christians. Books-some of them of great importancewere poured forth from the press, periodicals were maintained, and vigorous methods taken to make Malacca the centre of Christian propagandism on a large scale. A few years after the institution had been opened it was visited 


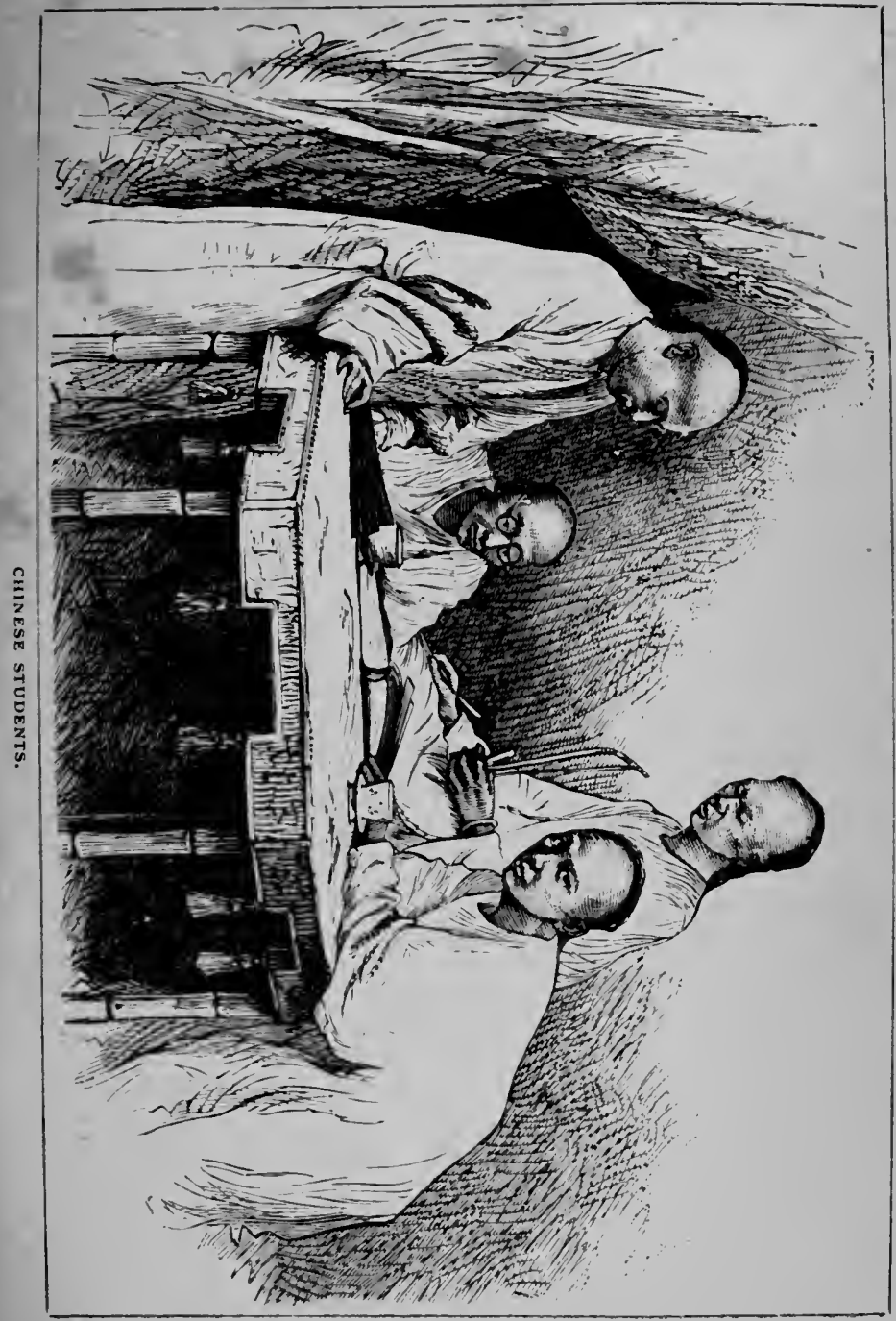


by the Hon. C. Majoribanks, the President of the Select Committee, who in the course of a deeply interesting account of his visit said :-

"When I visited the College it contained upwards of thirty students. Were its funds greater, its opportunities of doing good would be necessarily more extensive. It was a source of gratification to hear nearly every one of those boys reading with fluency the Bible in the Chinese and English languages. Many of them wrote elegantly both Chinese and English, and had attained considerable proficiency in arithmetic, geography, the use of the globes, and general history. 'Thus does a son of a Malacca peasant derive an enlightened education denied to the son of the Emperor of China." In I 820 Dr. Milne says : "Connected with the Mission are thirteen schools in all, containing about three hundred children and youths."

The higher work of conversion seems also to have been proceeding in some minds. A native printer, called Leang Afa, who acted as tutor, had professed faith in Christ, and after giving satisfactory evidence of his sincerity, had been baptised and received into Church membership. He composed and printed a paraphrase on several parts of the New' 'Testament, and when called to suffer persecution very patiently endured it. He maintained his faith to the end, having it tested by the loss of property, scourging, and imprisonment. He laboured as an evangelist in several parts of China, and was the first person ordained to that work by the London Missionary Society. It was through the reading of tracts written by Leang $A f a$ that the leader of the Taeping rebellion was led to an acquaintance with Christianity, some elements of which he professed and advocated in seeking to establish his mongrel government in China.

Several volumes of the gigantic I)ictionary were now completed and issued; but on November 25 th, 1819 , it was the unutterable pleasure of Dr. Morrison to be able to write to the Directors of the London Missionary Society that the 
greatest object of his life and the largest hope of his heart was realised. The whole Bible was now translated into the Chinese tongue.

$\mathrm{He}$, of course, had by far the larger share of the great work; but Mr. Milne had given most effective and willing service since his acquaintance with the language had enabled him to do so. The whole of the New Testament was the work of Dr. Morrison, the Chinese MS. found in the British Muscum being a basis for a part of it; and of the Old Testament he had done the whole, with the exception of the Books of Deuteronomy, Joshua, Judges, Samuel, Kings, Chronicles, Ezra, Nehemiah, and Job, which had been translated by Mr. Milne. In his letter to the Society Dr. Morrison expressly disowns any claim to perfect correctness, and only professes to have laid a foundation for other and more perfect translations in after years. A few extracts from the letter will be interesting. He says :-

"If Morrison and Milne's Bible shall in China at some subsequent period hold such a place in reference to a better translation as Wickliff's or 'Tyndale's now holds in reference to our present English version, many will for ever bless God for the attempt; and neither the Missionary Society nor the Bible Society will ever regret the funds they have expended, or shall yet expend, in aid of the object.

"It is not yet five hundred years since Wickliff's bones were dug up and burnt, chiefly because he translated the Scriptures; and it is not yet three hundred years since Tyndale was strangled by the hands of the common hang. man, and then burnt, for the same cause. The alleged inaccuracy of Wickliff's and of 'Tyndale's translations was the ground of cavil with all those who were averse to any translations of the sacred Scriptures; and it is but two hundred and seventy-seven years since the English Parliament decreed that 'all manner of books of the Old and New Testaments, of the crafty, false, and untrue translations of Tyndale, be forthwith abolished and forbidden to be used 
and kept. If such things occurred so recently, more modern translators need not be surprised if their, works are censured and condemned.

“King James' translators were fifty-four in number, and rendered into their modern tongue in their. native country under the patronage of their prince. Our version is the work of two persons, or at most of three (including the author of the MS.), performed in a remote country, and into a foreign and newly acquired language, one of the most difficult in the world, and the least cultivated in Europe. The candid judge of men's works will not forget these circumstances.

"In my translations I have studied fidelity, perspicuity, and simplicity. I have preferred common words to rare and classical ones. I have avoided technical terms which occur in the pagan philosophy and religion. I would rather be deemed inelegant than hard to be understood. In diffcult passages I have taken the sense given by the general consent of the gravest, most pious, and least eccentric divines to whom $I$ had access.

"To the task I have brought patient endurance of long labour and seclusion from society; a calm and unprejudiced judgment, not enamoured of novelty and eccentricity, nor yet tenacious of an opinion merely because it was old, and, I hope, somewhat of an accurate mode of thinking, with a reverential sense of the awful responsibility of misinterpreting God's word. Such qualifications are, perhaps, as indispensable as grammatical learning in translating such a bock as the Bible.

"To have Moses, David, and the Prophets, Jesus Christ and His apostles, using their own words, and thereby declaring to the inhabitants of this land the wonderful works of God, indicates, I hope, the speedy introduction of a happier era in these parts of the world, and I trust that the gloomy darkness of pagan scepticism will be dispelled by the Dayspring from on high, and that the gilded idols of 


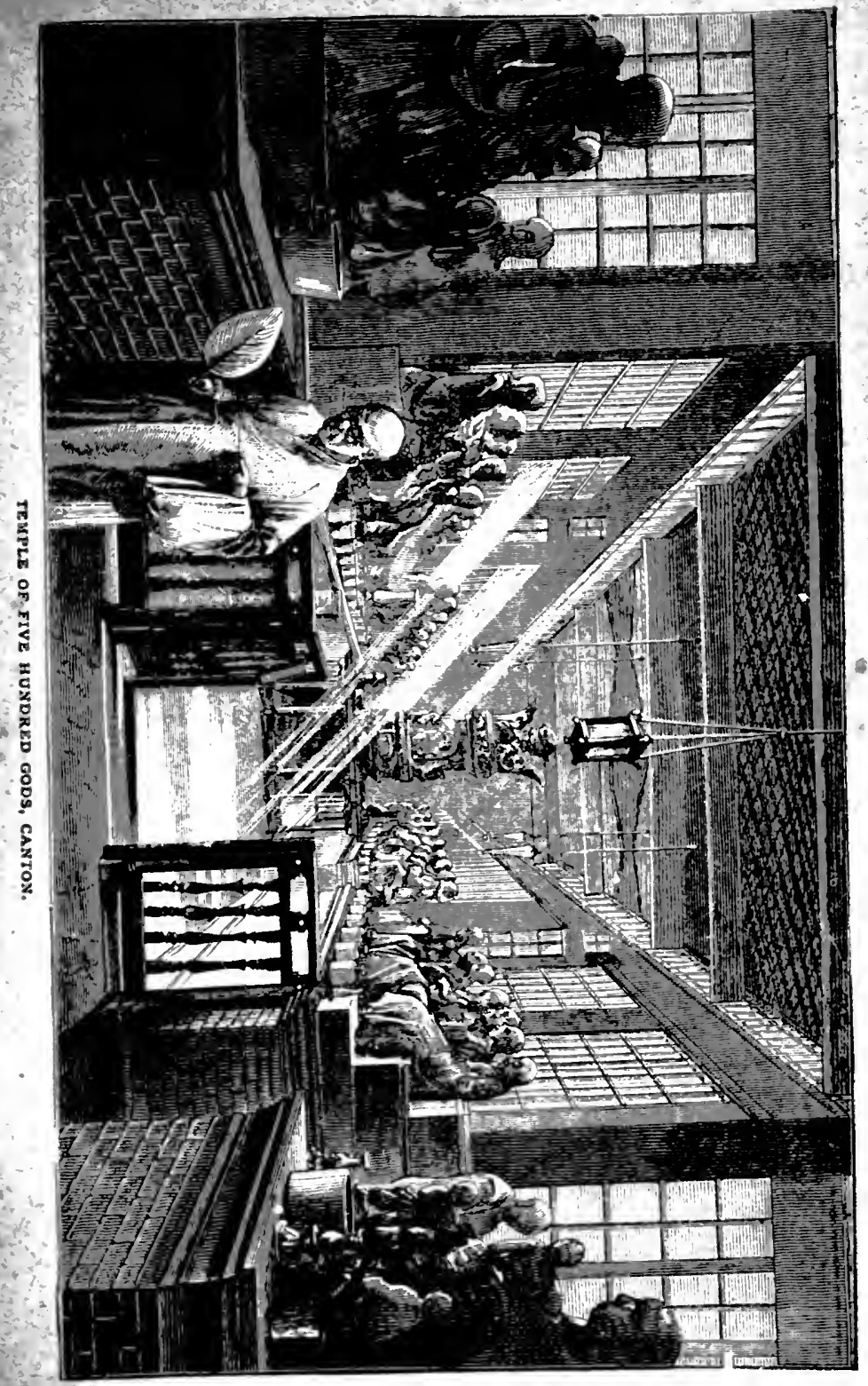


Buddha, and the numberless images which fill the land, will one day assuredly fall to the ground before the force of God's word, as the idol Dagon fell before the ark.

"Tyndale, while he was being tied to the stake, said, with a fervent and loud voice, in reference to Henry VIII., 'Lord, open the King of England's eyes;' and his prayer seems to have been heard and answered. Let us be as fervent in a similar petition in reference to the Sovereign of this Empire.

"In the Apostle's words I conclude this letter : 'Finally, Drethren, pray for us, that the word of the Lord may have free course and be glorified, even as it is with you." "

The joy entertained by the friends of Christian missions throughout Europe and America on the accomplishment of this great work was intense. Congratulations to Messrs. Morrison and Milne poured upon them from many quarters, the University of Glasgow conferred the degree of D.D. on Mr. Milne, and fervent gratitude was expressed to the beneficent Providence which had presided over their labours. The Rev. G. Burder, D.D., Secretary to the London Missionary Society, wrote :-

"The herculean task is at length completed. To Him alone who gave the power to effect this great work, and who alone can render it effectual for its intended purposethe illumination and renovation of human minds-to $\mathrm{Him}$ alone be the glory now and evermore. But, my dear friend, we ought not, we will not, we do not, forget the laborious agents whom $\mathrm{He}$ has been pleased to employ for this great end. We thank Him for you and your helper, Mr. Milne. IVe bless God, who has continued your lives in a sultry climate, maintained your mental and corporal powers, and spared you to see the completion of your great labour. . . . Never mind what opponents say. The work is done, and God will bless it ; nor will $\mathrm{He}$ forget this work of faith and labour of love when $\mathrm{He}$ shall render to every man according to his works. Bless God, my dear sir, that ever you were 
born, and born again, and enabled to effect this great work. You have lived to good purpose in having lived to publish a Chinese Bible. Thank God, and take courage."

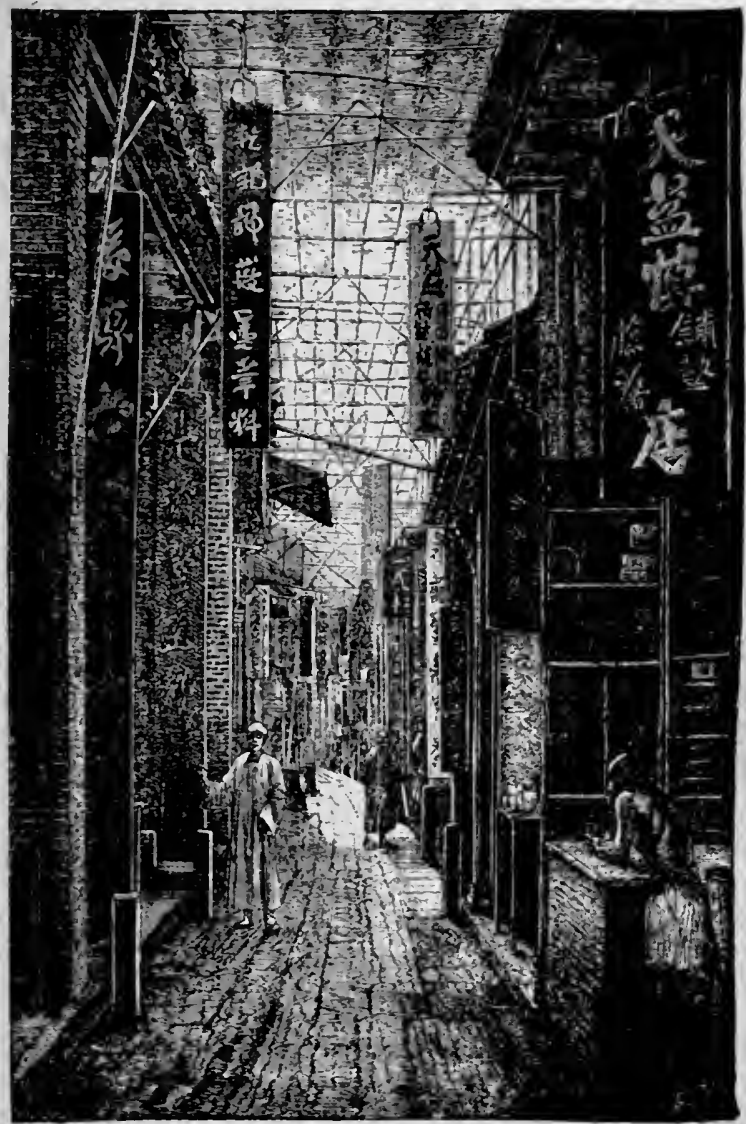

A'OTHECARY STREET, CANTON.

The Committee of the British and Foreign Bible Society wrote in a similar strain of thanksgiving and congratulation, 
and granted a fresh sum of one thousand pounds in aid of the multiplication and circulation of copies of the translation. The Committee of the American Bible Society presented Dr. Morrison with a copy of the best edition in octavo of the Bible, in splendid binding, as an expression of its esteem and approbation, and the American Board of Commissioners for Foreign Missions wrote offering their most cordial thanks and congratulations. Besides these, Sir George Staunton and many other eminent scholars wrote in a similar strain, giving proof of the intensity of interest felt throughout the Christian world in the great achievement.

This absorbing task being now accomplished, Dr. Morrison pursued his work in other directions with unwearicd assiduity. The Rev. Dr. Baird, principal of Aberdeen University, had written to him seeking information as to the poor of China. This led him, in connection with Dr. Livingstone, the surgeon of the East India Company in Canton, to give attention to the enormous numbers of destitute poor and sick people who infest all Chinese towns and cities. The blind, the lame, the leprous, often filled the highways, and their condition excited little concern or compassion. The melancholy condition of these sufferers was only equalled by the gross ignorance that prevailed as to medical science. In the public streets and markets might be seen here and there a stall on which dried vegetable substances were exposed for sale, these being sold for any, and some for every, complaint, without an attempt at discrimination. 'The apothecaries' shops at Canton contained professedly about three hundred medicines, but only thirty were in absolute practice, whilst one eminent physician chiefly used only one-viz., rhubarb. His name was Wang, "a king," and in allusion to his practice he was called "The Rhubarb King." To meet this crying evil, Dr. Morrison opened a dispensary for supplying the poor with advice and medicines, superintending it himself for one or two hours daily, and being 
assisted in its management by Dr. Livingstone. He also purchased a Chinese medical library, consisting of upwards of eight hundred volumes, with a complete assortment of Chinese medicines, and engaged a respectable Chinese physician and apothecary, with the occasional attendance of a herbalist (whose complete stock he purchased for Dr. Livingstone's analysis), to explain the properties of the various herbs he collected and sold.

The afflicted Chinese of Canton and the adjacent districts crowded to this dispensary, and in a few months thousands of cases had been under treatment with gratifying success. 'This institution must be considered as the forerunner of a crowd of similar institutions, which have been established in connection with Christian missions in the East, and which are increasingly vindicating their claim to be considered an integral part of Christian propagandist enterprises.

Amidst more important occupations, I)r. Morrison found opportunity to send from the press several useful works of lesser account. One was a small treatise contrasting the principles of the heathen religions of China with those of Christianity; another was "A Voyage Round the World," which was meant to enlarge and enlighten the ideas of the Chinese as to mankind, and especially as to Christians and practical religion; a third was "Translations" of the Morn. ing and Evening Prayers of the Church of England, and also of the Psalter. Two thousand copies of this last work were ordered by the Prayer liook and Homily Society for distribution amongst the Chinese.

On April 23rd, 1820 , Mrs. Morrison, in much improved health, embarked with her two children in the Marchioness of Ely, to rejoin her husband in China. On August 23rd he had the great happiness of receiving them at Macao, and of spending a few wecks of blessed home enjoyment in their society. Then he had to leave them, to undertake again his official duties in Canton. 
In the meantime Dr. Milne had devoted himself to the management of the College at Malacca, and other missionary work, with such devotion as greatly to overtax his never very robust constitution. He had much to try him in the midst of his labours, but in March, 1819 , he was called to endure the severest earthly trial. Death had already snatched from him two dear children, but now his beloved partner was called from h:s side. She died in perfect peace and full hope of a glorious immortality. Most bitterly did the bereaved husband and father feel these trials. From the time of Mrs. Milne's departure from earth, to the time of his own death, his journal was often blotted and blurred with his tears. "O Rachel! Rachel!" he wrote, "endeared to me by every possible tie! But I will try not to grieve for thee, as thou didst often request before thy departure. I will try to cherish the remembrance of thy virtues and sayings, and teach them to the dear babes thou hast left behind. "The Lord gave, and the Lord hath taken away; blessed be the Name of the Lord.'"

From this time he wrought on, with the interests of his four surviving children resting heavily upon his mind. And there was sufficient in the expenses and difficulties of the College to cause both Dr. Morrison and him great anxiety. The wealthy East India Company had promised to give twelve hundred dollars annually towards its maintenance, but, on Lord William Bentinck's appointment to the Government of India, the allowance was withdrawn. The members of the Select Committee of the Company in China were, however, so convinced of the excellence of the institution, that they wrote a joint letter to Dr. Morrison, expressing their deep regret at the step taken, and stating that they had resolved to make up the amount themselves, so that its influence might be still exercised for the good of the East. At this time, also, several missionaries were sent out by the London Missionary Society to labour in Batavia, Penang, Singapore, and Malacca, and an experienced 


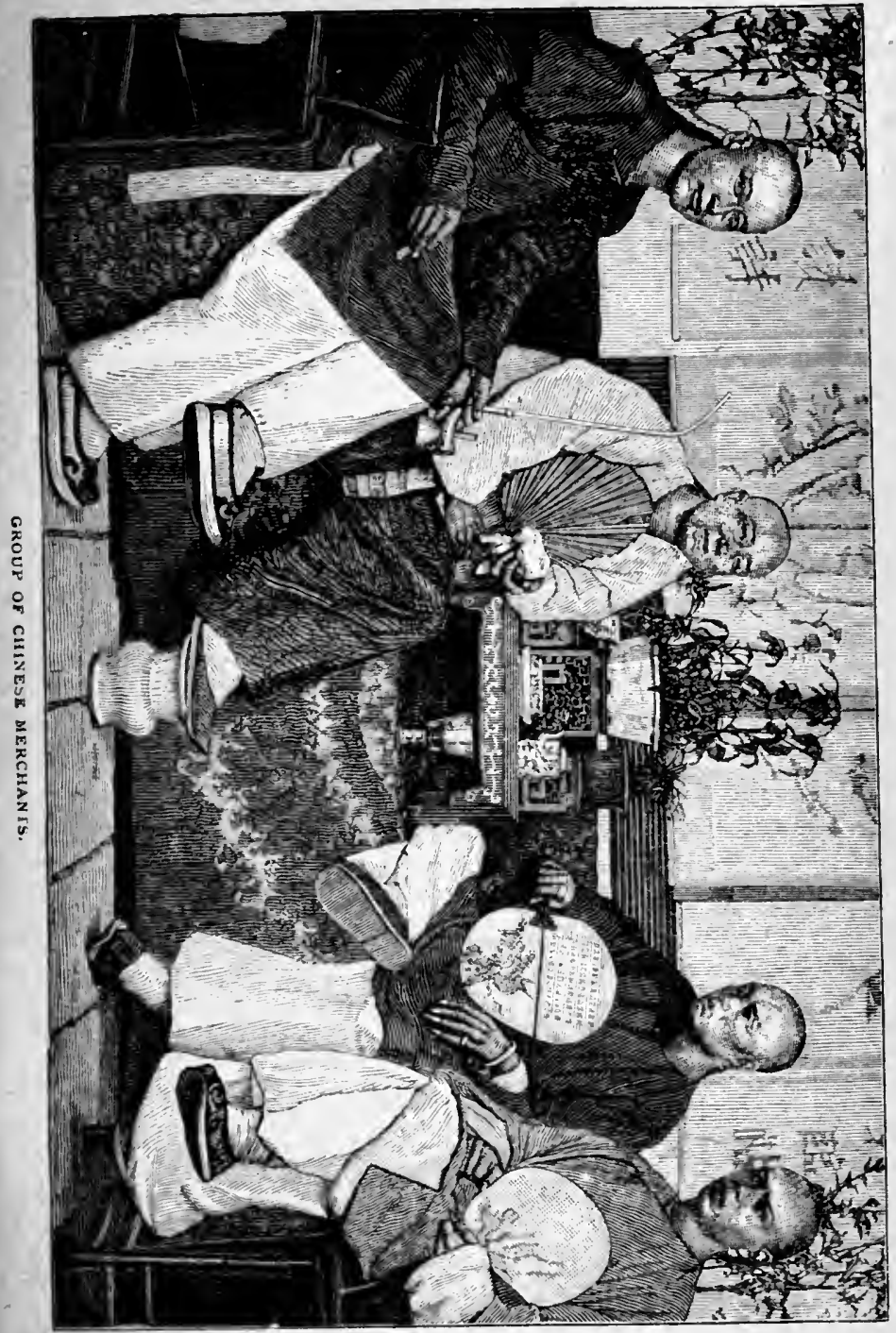


printer arrived at Malacca to aid Dr. Milne in his various efforts to scatter a Christian literature throughout the settlements.

In the spring of $182 \mathrm{I}$ Dr. Morrison returned to Macao, and for a bricf interval he was permitted the delightful and restful joys of home life. But a dark cloud hovered over that household, and for a time filled it with gloom. He had occasion soon to write the following letter to his fatherin-law, Mr. Morton: "My beloved Mary, from the last time of her arrival in China, enjoyed remarkably good. health, seldom requiring medical aid. We were pleasantly situated, and had a piece of ground before our house by the scaside in Macao, where we and the children walked happily together every evening. We then, after family prayers, sat down round a table, all occupied in something useful or amusing. My Mary was occupied innocently and pleasantly in making clothes for her expected babe, and got all her house in order most comfortably; yet amidst this she never went to rest, nor rose to work, without reading considerable portions of her Bible; and since she came out to China, she read, I believe, the whole of Milner's 'Church History,' which she found edifying."

On June the 8th she was suddenly taken ill, and notwithstanding that doctor, husband, and friends did all that human skill or affection could devise, she died in her husband's arms on Sunday evening, the I oth. Dr. Morrison wished to bury her by the side of her little son James, whose body lay in a grave amongst the hills; but the Chinese would not suffer the grave to be reopened. The Roman Catholics refused to allow the dust of a Protestant to repose in their cemetery, and therefore the Committee of the English Factory purchased a piece of ground, worth about a thousand pounds, as a Protestant buryirg-place, and here the remains of Mrs. Morrison were reverently placed.

The blow was so sudden and afflictive to Dr. Morrison, and the desolation was so awful, that he seemed stunned 
and paralysed. His health and spirits suffered for a considerable time; and while he diligently fulfilled his official duties, and wrought with undininished ardour for the completion of his Dictionary, his correspondence, generally so varied and multitudinous, was limited to his nearest relatives. When his duties required his presence in Canton he took his son with him, leaving his daughter in the care of his kind friends Dr. and Mrs. Livingstone, at Macao, intending to send both children to England as soon as a convenient opportunity occurred.

His skill and tact as an interpreter and diplomatist were to be very severely tested on his arrival at Canton, in consequence of a fracas which broke out between the English and Chinese authorities. Some men from an English frigate had gone ashore at the island of Lintin, adjacent to the Chinese coast, for the purpose of obtaining water. Although they were unarmed, a party of Chinese attacked them, and several were wounded. A company was sent from the ship to defend them, and in the struggle two Chinamen were killed. 'The local government demanded that the murderers, as they were called, should be given up, to be executed according to law. The English denied that there was any murder in the case, and refused the demand. Both parties firmly maintained their ground, and as a result trade was interfered with, the relations of the two nations were strained, the English Factory at Canton was closed, its employés and stock were put on board ship, and an unfriendly attitude was taken up. Some of the Chinese merchants deeply regretted the affair, and did their best to end the unfortunate quarrel by seeking to induce the English to accommodate matters somewhat. 'They even suggested to the officers of the frigate that they should say that two of their men had fallen overboard, and that, as these were the murderers, they could not be given up. They would have been content to allow the matter to blow over on such a wild story as this; but their pride would not allow them to acknow- 
ledge the plea that the men had been killed by the English in self-defence. The English would not concede any point, and especially would not give up the men to be strangled to death, as they certainly would have been, if surrendered. The result was that two months were spent in wearying and vexatious correspondence, ending at last in a compromise to the effect that friendly relations were to be re-established and trade resumed, on the condition that the English Government would cause full examination to be made into the circumstances of the mêlée. Mr. Morrison's services in the discussion were invaluable, and on its conclusion a report was drawn up by Sir James Urmston, in which the following words occur: "During the progress of this affair, which had involved the East India Company's representatives in one of the most serious, vexatious, and harassing discussions they had ever been engaged in with the Chinese, the zeal and exertions of Dr. Morrison were unremitting. His extensive and indeed extraordinary knowledge of the Chinese language, both written and colloquial, and of the system, character, and disposition of the Chinese Government, enabled him clearly and fully to comprehend its sentiments, views, and meaning, as well as to detect the sophistry, duplicity, and even falsity which but too frequently marked the official documents of the local authorities, as well as the language and arguments of the Hong merchants; the latter being always the vehicle of communication between their Government and foreigners. This close and correct insight into the Chinese documents proved of the utmost importance to the Select Committee, who were enabled thus to frame their correspondence and communications with the Chinese in a form, language, and spirit suitable to meet and to resist the arrogant language and pretensions, and the unjust demands, of the Viceroy of Canton and his colleagues. These communications were translated into such perfect Chinese by Dr. Morrison as to render it impossible for the Chinese Government to misunderstand, or even to 
affect to misunderstand, the feelings, sentiments, and determination of the East India Company's representatives; and this circumstance is at all times of immense importance in negotiations or discussions with the Chinese. Dr. Morrison's invaluable talents and services were fully understood and appreciated by those whose vast and important interests he had on this as well as on various former occasions so essentially benefited."

The Company's ships returned to their usual stations, the trade resumed its course, and Dr. Morrison arranged for his children to return to England. His daughter sailed in the good ship Kent, in the care of Mr. and Mrs. Maloney, from whom she received almost parental kindness. The little boy sailed in the Atlas, under the protection of Mr. Dill, the surgeon. In writing to his brother concerning their departure Dr. Morrison said: "I desire that my children may be taken good care of, and be brought up in a plain way, but, above all things, be taught to fear 'the Lord betimes' -that is wisdom."

Dr. Morrison now retired to his desolate home at Macao, and deroted himself with renewed application to his missionary duties and the completion of his Dictionary. He was, however, alarmed at the intelligence which speedily reached him as to the failing health and critical condition of his beloved fellow-labourer 1)r. Milne, who secmed to manifest an ever-intensifying zeal as his physical capabilities appeared to diminish. For upwards of two years the concerns of the Mission in Malacca derolved almost exclusively on him. He negotiated with the Government, took the oversight of Mission buildings, edited the Gleaner, taught in the College, translated pamphlets and books, and regularly preached the Word. His chief work was the translation and composition of Christian books. His part in the translation of the Old Testament has already been narrated; but, besides this, he wrote in Chinese or English not less than fifteen tracts, varying from ten to seventy leaves each, besides a 
full commentary on the Epistle to the Ephesians, and an elaborate work in two volumes, called an "Essay on the Soul." Some of his tracts published in Chinese are unequalled for their acceptability and their adaptation to particular cases.

In reviewing these results of intense application shortly before his death he says: "They appear many for my strength, especially if to these the care of my family be added. I humbly hope also that they are and will be useful to the Church of God. But when I view them as connected with the imperfection of my motives and the dulness and deficiency of spiritual affections in them, I am disposed to adopt the language of the Prophet, "Very many and very dry.' They appear almost to be dead works. Woe's me! Woe's me! My dead soul! Lord, make it akin to 'Thee, and this will give life to all my labours."

Amidst his manifold labours his health failed; he had many premonitions of danger, followed by partial recovery. Profuse spitting of blood indicated disease of the lungs; but it was afterwards ascertained that the liver was the seat of his complaint. He took a voyage to Penang, hoping thereby to recruit his health; but deriving no benefit from the change, he returned, utterly worn out, to Malacca, only anxious to die at his post. There he passed peacefully to his rest and reward, being thus reunited to his faithful partner, and leaving four children utterly orphaned and cast destitute on the fatherhood of God. He had written to his recently widowed friend, Dr. Morrison, from Penang, and on June 3 rd, I822, the following reply was penned:-

"I have received your letter from Penang, and deeply regret the afflicting news which it contains. Oh that God may spare your life and restore your health! I am going on mourning all the day-an unprofitable servant; Lord, pity me!

"Ahëen has written to me from Canton, saying that he is convinced of sin, and desiring to be washed therefrom by 
the Saviour of the world, in token of which he asks if he may be baptised. 'The lad Asam, the younger, seems to understand the outline of the Gospel, and says he believes it. I really hope Ahëen is sincere-he was always too proud, as well as a conceited Tŭh-shoo-jin [a literary person], to say now that he was convinced of $\sin$ and wanted saivation, if it had not some reality in it. He is a man of few words, and naturally cold-hearted. If indeed he now looks to the Saviour, God be praised for giving to worthless me some fruit of my feeble labours! Alas! I write this fearing you are already beyond the reach of letters."

He was indeed beyond the reach of letters. On June end, at the early age of thirty-seven, this shepherd lad from the hills of Scotland, who became by the force of consecrated toil a learned and successful pioneer missionary, was called to the eternal home.

From May $24^{\text {th }}$, the day on which he returned from Penang, it was evident to all who saw him that his usefut and laborious life was drawing to a close. But having begun several works which promised to be useful, both to the heathen and future missionaries, he was earnestly desirous of being spared to finish them. But such was not to be. I His disease became rapidly more painful and dangerous. It was so agonising for him to speak that, except to settle his own affairs or those of the institutions he had charge of, he uttered few words. As he drew near to the end he expressed his fim faith of salvation through the merits of Jesus, and appeared more at ease than he had done for some time. His friends thought that this arose from some improvement in his condition, but it was from exhaustion of nature, for in a short time, without a struggle or a groan, he passed away. His body was carried from the Anglo-Chinese College to the Dutch burial-ground, and laid in a vault he had prepared for his wife and children. The funeral was numerously attended by both natives and 
foreigners. The Government officials, the foreign missionaries, the members of the Dutch church, most of the respectable inhabitants of Malacca, and hundreds of Chinese and Malays, were present to offer their tribute' of respect and reverence to his memory.

His character was summed up by Dr. Morrison in these fitting words: "Dr. Milne appears to have possessed naturally a very ardent, impetuous, determined mind, yet softened by mildness of manner; and after it was converted, turned from Satan to God, it retained its natural ardour and impetuosity, but directed to new and very different objects from what it previously was. $\mathrm{He}$ was now fully convinced that the cause of Missions was the cause of heaven, and neither fire nor water could impede his onward course. He served with courage and fidelity ten years; and then, worn out by useful toils and hard service, died at his post."

Dr. Morrison was at this time meditating a journey to England, in order to visit old friends and kindred, and to enjoy a well-earned furlough. But on the news of Dr. Milne's death he gave up for the present all thought of a holiday, and resolved to repair to Malacca to arrange for the future working of the Mission and the College. With characteristic benevolence, also, he resolved to adopt, as his own son, little Robert Milne, named after himself, and to provide for his maintenance and education with his own children.

In November of this year a fire broke out on the west side of Canton, about a mile north of the European Factories. It raged furiously for several days, and burnt every building westward for a mile and a half, and indeed did not cease to burn till no buildings were left. Thousands of Chinese shops and houses were destroyed, and millions of pounds worth of property was lost. 'The East India Company's loss was estimated at one million; and the loss of life through the fire, terror, trampling to death, 
and attacks of cruel banditti was awful and horrible. This was an additional trial to Br. Morrison, as be lost much property by the fire, and especially a hundred pounds worth of paper he was about to send to Malacca for a fresh edition of the New 'Testament.

On January 17 th, 1823 , Dr. Morrison left Canton for Malacca, and on the $2 g^{\text {th }}$ of the same month landed at Singapore, then a newly formed English settlement in the Malayan Archipelago. He was received by the LieutenantGovernor, Sir 'I. Stamford Raffles, with great friendliness. They were men of sympathetic fecling; and earnest conference on several subjects for promoting the welfare of the colony and the Malays occupied the period of the visit. The result of the interview was the resolve to establish at Singapore an institution similar to that at Malacca; and as the latter settlement was under the Dutch (iovernment, to unite both under one management, with the title of "The Singapore Institution." $\Lambda$ meeting of the principal inhabitants of the settlement was summoned, and the proposal laid be'ore them. It was decided to adopt the scheme: the College at Malacca to be carried on as at present with its special departments, and the new institution to take up branches of knowledge and science which the older one had not been able to embrace. A liberal subscription followed. Dr. Morrison was appointed VicePresident, and subscribed upwards of fifteen hundred dollars, besides spending much more in the elearing of a site of land which he obtained as a grant from the Government. On February ist he arrived at Malacca. He found everything in a healthy and hopeful condition. He says: "The College and the native students gave me great satisfaction. The Chinese youths sang the hundredth Psalm to Luther's tune. It was composed in Chinese by my former assistant, Kŏ-Sëen-săng. Finding the good use which had been made hy my dear William of my books in Chinese, and of my funds, and the freedom of worshipping 
God without Mandarin interference, altogether produced on my mind a most pleasing effect. Oh, how grateful should I be!" He filled up the vacant post of principal of the College by the appointment of the Rev. David Collie, who had been sent out by the I.ondon Missionary Society in 1822 , and who had shown remarkable aptness in gaining acquaintanceship with the Chinese language. Mr. Collie fulfilled the duties of the office with great ability up to the time of his death in 1828 .

The year 1823 was a memorable one in the life of Dr. Morrison, owing to the publication of the Anglo-Chinese Dictionary, which must be considered as the great work of his life. He had been engaged upon it sixteen years, and in connection with its composition he had accumulated a library of about ten thousand Chinese volumes. It was now issued at a cost of twelve thousand pounds by the East India Company. It filled six large quarto volumes, each equalling in size a family Bible; it contained four thousand five hundred and ninety-five pages, and recorded forty thousand words expressed by the Chinese character. Having accomplished so marvellous a work, it was not wonderful that his name became universally famous. Testimonies as tn the value and importance of the publication came from all sides. Dr. Montucci, of Dresden, an erudite Oriental scholar, said: "I am free to assert that Dr. Morrison within these ten years has published volumes by far more useful to the European student than all the printed and MS. works published by the missionaries in the course of the last century." M. Remusat, of Paris, said: "The AngloChinese Dictionary by Dr. Morrison is incomparably superior to every other." The book is indeed almost as much an encyclopædia as a dictionary ; biographies, histories, and notices of national customs, ceremonies, and systems abound, making it a repertory of information on all matters touching Chinese life and literature.

Dr. Morrison writes, under date November Ioth, $\mathbf{I}_{23} 3$ : 
" $\Lambda \mathrm{fa}$, whom our dear Milne baptised, has led his wife to embrace Christianity, and proposes to bring his little son to be baptised." And on the 2 oth he wrote: "To-day Leang Afa, our Chinese fellow-disciple, brought his son Leang-tsinthh (entering on virtue), and had hin baptised in the name of God the Father, Son, and Spirit. Ols that this small Christian family may be the means of spreading the truth around them in this pagan land!"

The time had now come when Dr. Morrison felt he might gratify his long-deferred desire of visiting his native land, and associating once more for a brief period with his beloved distant friends. He therefore wrote to the Select Committee of the Fast India Company: "Having spent sixteen years in China, subjected to sedentary occupation, in translating, writing the Chinese Dictionary, and other works, and now fecling indications of my constitution being affected by the want of bodily exercise, I have determined to avail myself of the liberal permission granted by the Honourable the Court of Directors to visit England, with certain allowances. I intend going in the Waterloo, with Captain Alsager. Thus I shall leave China in the end of December, 1823 . In the close of I)ecember, $182_{4}$, I purpose to quit England and return to China, siti Bengal ; by which means I hope to resume my duties in the Factory in August, 1825 .

"For the benefit of Chinese literature in England, I purpose taking thither and leaving there my Chinese library, consisting of several thousand volumes, to ship which on board the Waterloo I request the Committee's permission. And if the Committee can authorise me to draw such part of my allowance during absence as they may see fit, in England, on my arrival there, it will be a great accommodation to me, and will be considered a favour."

The Select Committee willingly granted all he desired. He sailed in the Company's ship IVaterloo early in December, 1823 , and arrived in England in March, 1824 , accompanied hy a Chinese servant who had lived with him for several 
years, and had made a consistent profession of Christianity. One deep regret he had in leaving China, that he was unable to leave behind him a missionary to continue his work in Canton or Macao. He had urgently besought the societies of England and America to appoint a helper, who might be his successor in the event of his death, but no provision had yet been made. He therefore ordained Leang Afa to the office of Evangelist. He had maintained a good confession for eight years, and he was now commissioned to carry on spiritual work amongst his countrymen in Canton as opportunities allowed.

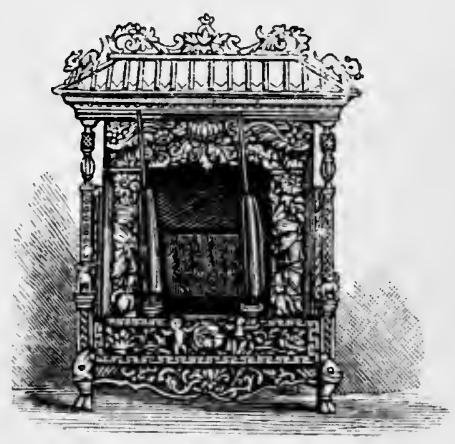




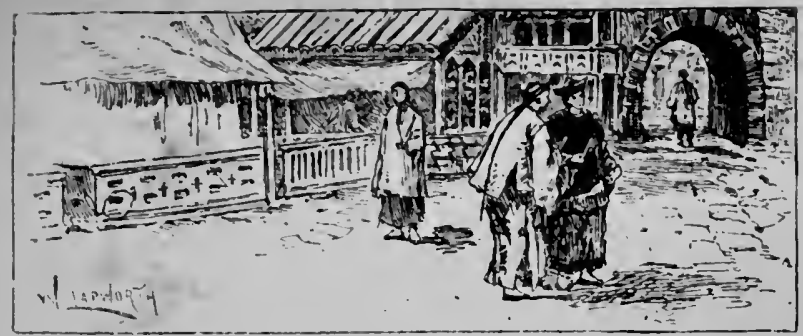

CHAPTER XI.

WORK IN ENGLAND.

"I would not have this perfect love of ours

Grow from a single ront, a single stem,

Bearing no goodly fruit, but only flowers

That idly hide life's iron diadem :

It should grow always, like that Eastem tre

Whose limbs take root and spread forth constantly;

That love for one, from which there doth not spring

Wide love for all, is but a worthless thing."-Lowel.

TIIE reputation which Dr. Morrison had won for himself, for his devotion as a Christian missionary, and his erudition as a philologist, secured him, on his arrival in England, a gratifying reception from persons of all ranks, and from many philanthropic and learned societies. Trouble and vexation, however, attended his arrival with regard to the enormous Chinese library he had brought with him. Previous to leaving China he had stated to the British authorities his object in bringing it to England, which was to present it to some public institution, by which it might be made accessible to all desirous of learning the Chinese language. It was a valuable collection of books. Many of them had been obtained with great difficulty, as the natives were by law forbidden to sell their books to 
foreigners. Some of the works were rare and expensive, so that the cost to Dr. Morrison had been upwards of two thousand pounds. His design as to the library being stated to the Lords of the Treasury, a remission of the duty levied on foreign books was sought. Grave objections were entertained as to giving this permission, and Dr. Morrison was kept in suspense for some time, only to be informed that the library would be allowed to pass duty free on application from the public body for whom it was designed. This was tantalising in the extreme; the public body had not yet been found that would accept such a gift, and Dr. Morrison was not prepared to pay the large sum which was required to free the books from the hands of Custom House officers. Looking back upon the occurrence, it seems a paltry method of treating a liberal offer for the public good, to insist on a tax, simply because the benevolence is the act of an individual, rather than an association of individuals under some collective name. He was so discouraged as to have made up his mind to pay the duty, when a number of gentlemen, especially his old friend Sir George Staunton, pressed the matter so strongly upon members of the Ministry, that the books were allowed to pass free, and were deposited in a room on the premises of the London Missionary Society until they could be satisfactorily disposed of. This matter settled, no less an honour was to be offered to Dr. Morrison than to be presented to His Majesty the King. Sir George conveyed the news to him in these, words: "Mr. Wynn has very handsomely agreed to present you himself to the King on Wednesday, and to consult with Mr. Peel about the best mode of laying before $\mathrm{His}$ Majesty your translation of the Scriptures. Under these circumstances it might not be necessary for me to go; but as you are a stranger, Mr. Wynn wishes me to accompany you in order to ensure your finding him, and putting you at the proper moment into his hands, and this I shall be happy to do, and shall 
therefore, as before settled, call for you in Berners Street, on Wednesday, at half-past one."

At the appointed time Dr. Morrison accompanied Sir George Staunton to the Levee; and on being presented to the King, His Majesty recognised him in a manner which showed he was well acquainted with his merits and the value of his public services. He very graciously accepted a copy of the translation of the Bible and a map of Pekin, which

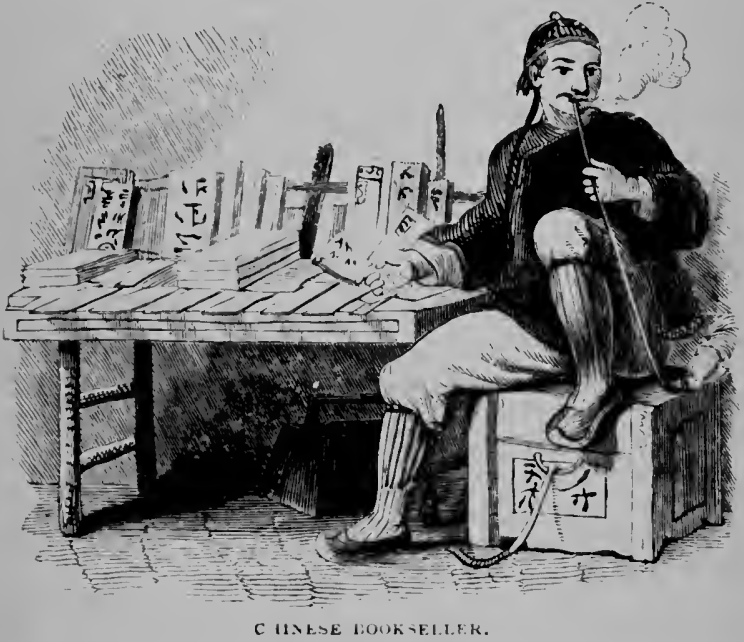

were acknowledged in the following letters, the first from the Right Hon. Sir R. I'cel, then Home Secretary, and afterwards Prime Minister, and the other from Dr. Sumner, afterwards Archbishop of Canterbury :-

"To Sir George Staunton, Bart., etc., etc.

" Whitenali, April I $2 t / l, 1824$.

"My dear Sir,-In laying before His Majesty the Chinese Bible, I have not failed to mention to His Majesty the very singular and meritorious exertions which have 
been made by Dr. Morrison to promote religion and literature in the East.

"His Majesty has commanded me to convey through you to Dr. Morrison the expression of his marked approbation of that gentleman's distinguished and useful labours.

"I have the honour to be, my dear Sir,

"Your most faithful and obedient servant,

"Robert Peel."

"To the Rev. R. Morrison, D.D., etc.

$$
\text { "Carlton Palace, April i4th, } 1824 .
$$

"Sir,-I have received His Majesty's commands to convey to you His Majesty's acknowledgments, and to express his sense of your attention in presenting, through Mr. Peel, a copy of your Chinese Bible.

"His Majesty has been pleased to direct me to take it into my particular care, as an important and valuable addition to his library.

"I have the honour to be, Sir,

"Your obedient and faithful servant,

"Charles R. Sumner, Librarian."

The Select Committee of the East India Company also introduced Mr. Morrison to the Court of Directors in the following flattering words, showing how groundless had been all the fears entertained that his official connection with the Company would be inimical to its commercial interests :-

"December $5^{\text {th, }}$ I823. We cannot permit Dr. Morrison to depart from the situation he has held for sixteen years in this establishment, with eminent advantage to the interests of the Honourable Company, without expressing the strong sense we entertain of the importance of his services, and of the perfect satisfaction we have derived from his abilities and general deportment during his residence in this country. We trust, therefore, we may be permitted to introduce Dr. Morrison to the notice of your Honourable Court as a gentleman meriting your best attentions." 
This was signed by all the members of the Select Committee, and consequently from the Directors as a body and from many of them personally he received attentive courtesy. The Court allowed him half his income while on furlough, and he was invited to a public dinner given in his honour by the Directors, where he formed acquaintance with some of the most distinguished personages of the time. Public engagements crowded upon him, leaving him no opportunity for rest, or for enjoying private fellowship with his friends. As soon as he could tear himself from pressing engagements in London he went down to his native county, Northumberland, and in Newcastle found himself again amongst many friends and relatives, who accorded him an enthusiastic reception. He arrived on April 18 th, and on the Sabbath preached to crowded congregations, hundreds being unable to gain admission. He proceeded, on the $23^{\text {rd, to }}$ Edinburgh, to visit his daughter, and, accompanied by her, returned to Newcastle, en route to Manchester, in order to take with him to London his son, to be present at the meetings of the various benevolent and religious societies in May. He was waited upon by the civil authorities, and invited to a public dinner given in honour of his visit. One gentleman still survives who recollects, with great distinctness, this visit to Newcastle. The vencrable and much-esteemed Rev. J. C. Bruce, I).D., LL.D., etc., etc., remembers I)r. Morrison paying a visit to his father's house, and says of his appearance: "As I remember him, he was a well-formed man about middle size, with dark and rather curly hair." Dr. Bruce also possesses a copy of his translation of the Bible and the Anglo-Chinese Dictionary.

In reference to this visit he wrote to Sir G. Staunton: "My reception in this town is as kind as I could possibly wish. It is interesting to me to revisit the streets and fields where I lived happily as a poor bashful boy, thirty years ago." His experiences in revisiting old haunts he afterwards described in writing to his niece on his return to China : 
"I felt deep interest in travelling over again the walks of my boyhood: St. John's Church, the Forth, Maiden Lane, the riverside, once so lovely to me; now, the dirty new coal shaft has disfigured all the high bank healthy walks, with the river between and the windmill hills opposite. At four or five in the morning, winter and summer, have I sallied forth to the walks I have now alluded to-but ah! how changed the circumstances. Holy Scripture, prayer, the Sabbath, and the assembly of God's people were then my delight-days never to return. But there is a better country, Hannah, and in China I am as near to it as in England."

He was overwhelmed with solicitations from all parts of England to preach and speak on behalf of various missionary and other societies, and he was obliged to appeal to his friends to be more considerate of his strength and ability. Wherever he went his presence was hailed with overflowing and devout enthusiasm, and the claims of China to the Gospel more fully acknowledged. He attended the May meetings of several of the leading religious societies, including those of the London Missionary, the British and Foreign Bible, the Religious 'Tract, the Prayer Book and Homily, and the Port of London Societies, with all of which he had become closely associated by his work in China, and which bonds were drawn the closer the longer he lived. In all these meetings the references to Dr. Morrison and his work were so eloquent, and were received with such enthusiastic applause, that his retiring modesty was very much tried. One interesting incident was afterwards recorded by the Rev. T. S. Grimshaw, in relation to the anniversary meeting of the Bible Society. He says: "The day had been signalised by Dr. Morrison having presented to Lord Teignmouth, the President, before a crowded and distinguished auditory, the Chinese version of the Bible, executed jointly by himself and the late Dr. Milne. The undertaking was said to have been the result of nearly twenty years' laborious toil and study, and justly considered to be 
an extraordinary monument of Christian piety and perseverance. Never shall I forget the deep interest of that impressive occasion. Dr. Morrison appeared in the front of the platform, holding the precious volume in his hand. Beside him stood his youthful son, brought forward, as it were, like another Hannibal, not indeed to stand pledged against his country's foes, but to be consecrated, on the altar of the Bible Society, against those of his Redeemer, and to share with his father in the honour of extending His everlasting kingdom. . . Mr. Butterworth stated the following fact: 'It is now many years ago that, in visiting the library of the British Museum, I frequently saw a young man, who appeared to be deeply occupied in his studies. The book he was reading was in a language and character totally unknown to me. My curiosity was awakened, and apologising to him for the liberty I was taking, I ventured to ask what was the language that engaged so much of his attention. "The Chinese," he modestly replied. "And do you understand the language?" I said. "I am trying to understand it," he replied, "but it is attended with singular difficulty." "And what may be your object," I asked, "in studying a language so proverbially diffieult of attainment, and considered to be even insuperable to European talent and industry?" "I can scarcely define my motives," he remarked; "all that I know is that my mind is powerfully wrought upon by some strong and indescribable impulse; and if the language be capable of being surmounted by human zeal and perseverance I mean to make the experiment. What may be the final result time only can develop. I have as yet no determinate object in contemplation beyond the acquisition of the language itself." Little did I think that I then beheld the germ, as it were, of this undertaking, the completion of which we have witnessed this day, that such small beginnings would lead to such mighty results, and that I saw before me the honoured instrument, raised up by the Providence of God, for enlightening 
so large a portion of the human race, and bringing them under the dominion of the truths of the Gospel.'"

'The remainder of the year was spent in visits to France, Ireland, Scotland, and all parts of England, with a view to excite deeper interest in the spiritual condition of China and other Oriental nations. With an entire disregard of his own ease, Dr. Morrison powerfully advocated the clairns of the heathen, urging the various Christian Churches to renewed efforts to evangelise the far-distant and ancient countries of the East. As a result of his labours a very large and widespread interest was awakened respecting the social and religious condition of a people concerning whom till then so little had been known. Several young men of piety and promise were led to devote themselves to mission work, who became subsequently successful and honoured instruments of spreading the Gospel in the East. Associations were also formed in large cities to aid the work of the Anglo-Chinese College at Malacca, and the missionary spirit throughout the land was greatly stimulated. Dr. Morrison says that for some months he "lived mostly in stage-coaches and inns," his letters were hurried and brief, and his life was an unbroken round of engagements. To extend a knowledge of China and the diffusion of Christianity, he crossed to France, being furnished by Sir George Staunton and other friends with letters of introduction to several distinguished personages in Paris. In crossing over to Calais he met with Lord William and Lady Bentinck, who offered him great attentions, taking him to their own hotel, and procuring for him the services of an agreeable guide and interpreter while he was in Paris. Lady Bentinck entered most sympathetically into his views for the enlightenment of the lands of the East, and when afterwards her husband was Governor-General of India, she fervently strove to use her influence in encouraging efforts for the diffusion of knowledge and religion.

In Paris he had interviews with, and received much 
courtesy from, Baron Humboldt, M. Remusat, M. Klaproth, Baron de Stael, M. de Saci, and other of the leading literary men of France. He was introduced to the Asiatic Society, the National Society, and others, and he returned to England satisfied that he had produced a deep impression on many minds favourable to efforts for the moral elevation of the East. On his return from France he hastened to Ireland, preaching at Bath, Bristol, and Liverpool on the way, to large and crowded congregations. In Ireland great enthusiasm was aroused wherever he went. In Dublin he prcached twice, and attended four meetings; and in these, as in all others in Ireland, the various denominations, not excepting the Established Church, vied with each other to do him honour. He spent two days with the Earl of Roden at Tullymore Park, then went to Belfast, and preached in Dr. Hanna's church, and from there went to the Giant's Causeway to inspect that most wonderful natural phenomenon, and then crossed over in a steamer to Greenock.

In Scotland he visited Glasgow, Edinburgh, and Perth, preaching and speaking cverywherc as to his great Mission; and went northwards to Aberdeen to see the orphan children of Dr. Milne, in whom he took an affectionate intercst, and earnestly enjoined upon his own children to cherish towards them a fraternal regard. Scotland, like Paris and Dublin, which he had already visited, poured out profuse tributes of admiration for his work; and amongst many invitations from distinguished persons was one from Sir Walter Scott, requesting him to visit him at Abbotsford. This courtesy, however, with many others, he was obliged to decline.

He was greatly encouraged by a gift of fifteen hundred pounds from Lord Kingborough towards the Anglo-Chinese College, and also three hundred volumes of valuable books for the library of the College. Sir George Staunton also contributed two hundred pounds, in addition to previous 
liberal gifts towards the same institution. The British and Foreign Bible Society voted a further sum of a thousand pounds to aid him in the circulation of the Scriptures, and authorised him to employ agents and colporteurs as he might find openings for them, to be usefully engaged in such work. Much other encouragement and help was volunteered for the furtherance of the objects he had-so much at heart.

$\mathrm{He}$ was increasingly anxious as to the destination of his vast accumulation of Chinese books, which lay in the meantime in the premises of the London Missionary Society. He had hoped to have induced one of the great national Universities to establish a Chinese Professorship, and to have accepted the library in connection therewith. 'This hope was not to be realised for at least two generations. The learned and religious mind of England was as yet but little prepared to adopt or embody the broad views of the large heart of the Chinese missionary as to the future of China, and the disposition of the library became a difficult problem. Ultimately it was presented to the Council of University College, London, and called "The Morrison Library," on the condition that it might be used by students of any denomination free of charge.

$\mathrm{He}$ preached one Sunday in Dr. Waugh's church, and revived many tender recollections in his mind. The venerable minister, then in extreme age, was present, and afterwards told him that his understanding and heart approved of every sentiment, and that if he could have a copy of the sermon he would print it.

Various religious bodies sought conferences with Dr. Morrison as to the best methods of carrying out their existing methods for the evangelisation of the East, or as to any more efficient means which might be adopted. One of his suggestions to promote Christianity in the East, which, like some other grand projects, was before its time, was the establishment of what was called "The Language 
Institution." The object of this effort was stated as a plan "for a more extensive diffusion of Divine truth, by means of a society which should promote the cultivation of all the languages of mankind, and afford to those benevolent persons who leave their native country with a view of imparting to the heathen the knowledge of Christianity every degree of assistance before they quit their native country." He was urged to write an appeal on this project by the London, the Church, the Baptist, and the Wesleyan Missionary Societies, and the Society was launched under the high patronage of Earl Roden, Lords Calthorpe and Bexley, Sir George Staunton, Sir T. Stanford Raffles, Sir R. H. Inglis, Barts., Mr. W. Wilberforce, and many other distinguished philanthropists. A suitable building was taken in Holborn, and the business of the Society set on foot. Dr. Morrison granted the Socicty the use of his library and museum, and opened the Chinese department by a course of lectures extending over three months. Thirteen students attentively followed him through this course, four of whom were dedicated as Christian missionaries in Malacca and the Indian Archipelago. Dr. Morrison's services were so eagerly sought, and were deemed so important, that he was induced to prolong his stay in England for another year, and he formed classes of young men and women, to whom he gave instruction on subjects relating to mission life among the heathen. He entertained the strongest conviction that women could never be elevated and sanctified in Eastern countries, except largely through the agency of Christian women. This conviction had been impressed on him by his observance of the social seclusion of married women, and of the superstitions which mixed thenselves with their lives from their marriage day. When a marriage engagement was formed for a Chinese girl, judicial astrologers were consulted, horoscopes were compared, and every magical art exhausted in order to select a lucky day, and to secure this the cere- 
mony was sometimes postponed for months. When the wedding day arrived presents were sent to the house of the bridegroom and of the bride. When the evening arrived the bridegroom came with an ornamented sedan and a cavalcade of lanterns, music, etc., to fetch home his spouse. On reaching his residence the bride was carried into the house over a pan of burning charcoal, which was on the threshold. From this time the Chinese woman was shut out from social intercourse, and found her chief delight, apart from family ties, in observing the idolatrous and superstitious rites of Buddhism. Dr. Morrison early perceived the importance of Christian ladies being employed to find access to the hearts of Eastern women and influence them towards the Gospel.

'The Language Institution did not long continue after his return to China ; but through its instrumentality, during its brief existence, till I 828 , several eminent missionaries were partially prepared and fitted for their great work. The Rev. Samuel Dyer, for sixteen years a devoted and successful missionary in Penang, testified that he and his wife found Dr. Morrison's lectures of such advantage, that they were able to converse with the people in six or seven weeks after their arrival, and that Mr. Dyer then preached in the language so as to be understood.

In consequence of Dr. Morrison's determination to remain a longer period in England, he removed to a quiet house in Hackney, attending, however, thrice a week to lecture at the Institution, and on the other three days teaching a class of ladies at his own house, who were studying the language with a view of going into the mission field. He also fulfilled many public engagements, wrote many papers in magazines on the language, religions, and philosophies of China, and issued two or three books on similar subjects. 'The strongest constitution could not bear so great and prolonged a strain, and it is not surprising that he was attacked by an illness which excited serious apprehensions on his behalf. He was 


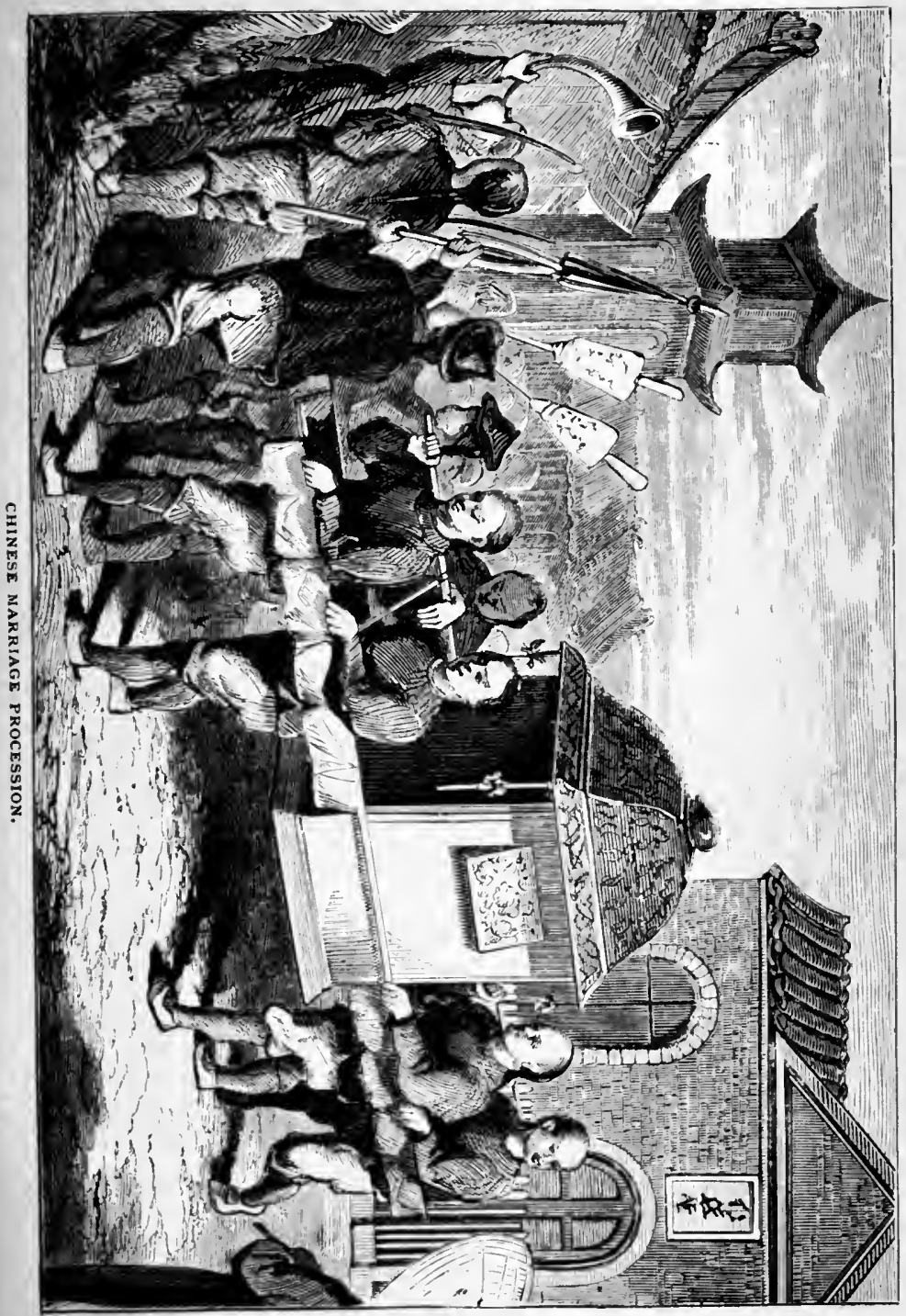


induced to accept the oft-repeated invitation to spend a few days with Sir George Staunton at Leigh Park, Hampshire. His stay of less than a week at this delightful residence was the longest interval of rest that he was allowed to indulge in during his two years' furlough in England. He was obliged to decline other opportunities of social enjoyment, only allowing himself respite from public duties for a very brief visit to Mr. Wilberforce, and to the Rev. C. Simeon, at Cambridge.

'The London Missionary Society conferred on him the honour, although contrary to its rules, of appointing him one of its Directors; and the Royal Society also spontaneously elected him a Fellow of its learned body. In common with all great public benefactors who have been successful in their work, he had to endure coldness and indifference from some quarters and contrary criticism from others. 'This led to a vigorous article appearing in a journal, setting forth in sympathetic words the great services he had rendered to the world. A few paragraphs from this article will express the prevailing opinion of his merits as a linguist and a missionary : "We have heard it well remarked that a man of talents and learning, who devotes them to the cause of religion, is, in the present day, situated something like the first heathen philosophers who embraced the faith of the despised Nazarene-he is frowned upon and contemned by his brethren of the schools. If the projects and performances of Dr. Morrison had originated with some sapient professor, too enlightened to discern the inferiority of Confucius to Christ, is there a man upon earth who does not believe that long ere now, every review, every magazine, every newspaper, would have sounded his praises all over the civilised world? . . Quickly as we must come to a conclusion we cannot refrain from looking back upon what has been done. Here is the Chinese language acquired; here are tracts in that language compiled; the Holy Scriptures translated into it; a grammar and dictionary of it composed, filling six quarto 
volumes; several other works written or translated in that most difficult of all tongues; the great scheme of a college formed and brought into active operation; and all this by the labours of Dr. Morrison and a colleague, acting under his directions. Is it possible not to feel astonished at such achievements of individual talents and industry? Why, we place in the highest rank of men of letters, we describe as a 'colossus of literature,' the great English lexicographer, Dr. Johnson; and he deserves it at our hands. We venerate the scholars who accomplished the translation of the Scriptures into their and our native tongue, and we do no more than what is just. But how much less than justice shall we do if, professing to desire the extension of Christianity or even literature, we fail to regard with high reverence, and to help with hearty co-operation, the man who, almost without assistance, has reduced to a system for foreigners, and enriched with an entire translation of the Bible for natives, the language of the greatest empire in the world."

During his residence in England he was married to Miss Eliza Armstrong, of Liverpool, a lady who proved a most amiable and congenial partuer; and, early in 1826 , he prepared to return with her and his children, whom he proposed to train for mission work as his successors in China. Letters of farewell and benediction poured upon him from distinguished scholars and philanthropists, and benevolent societies held meetings to commend him to God, and to offer him tender and affectionate good-will. One extract from the letter of I)r. Adam Clarke, the commentator, must suffice as a specimen of many friendly communications. Referring to his Commentary on the Holy Scriptures, he says :-

"One thing you must indulge me in, otherwise you will put me to pain. For some time I have purposed to beg your acceptance of a copy of this work for your own library. I am sorry it is not a large-paper copy, but there is not one of them left - they have long been out of print. I present this, out of high respect for your labours, and affection for your 
person. I have ordered it in good boards, for it could not (a few parts excepted) be bound without being spoiled; as the ink of the latter parts, not being sufficiently dried, would set-off. Your prayer for me, at the conclusion of your note, is worth a thousand copies of my work. I return you mine, in your own words: 'May the power of Christ rest upon your person, your family, and your abundant labours.' You had two lovely children, I think the finest I ever saw. I have carried them on my knees, kissed them often, and have borne them in my arms. It is many years since I saw them, and they can have no remembrance of me: please to tell them, however, that they have an old man's blessing and his heartiest prayers. When you sail, may His presence go with you, and give you rest. Amen."

According to usual etiquette, Dr. Morrison notified to the Court of Directors of the East India Company his intention of returning to China, requesting that he might be permitted to resume his duties at the Factory, and that his family might be allowed to accompany him. He waited before making final arrangements for the voyage, until he received an official answer to his application, not, however, anticipating any hesitation in granting his request. $\mathrm{He}$ was, therefore, much surprised on being informed that he was permitted to return in the Company's service, "for the term of three years," but that his two children were not permitted to return with him. Dr. Morrison submitted with as much grace as possible to this ungracious refusal, contenting himself with sending a memorial to the Directors, recalling the services he had rendered to the Company in China for sixteen years, and expressing his disappointment that so small a favour had been refused. To this application no answer was vouchsafed for some weeks, when he received a reply stating that under all the circumstances of the case he was permitted to take his two elder children back with him. Thus he was spared the pang of being again separated from them. 
A valedictory service, held in Hoxton Chapel, and attended by many eminent ministers, the venerable Dr. Waugh amongst them, was profoundly affecting. Dr. Morrison gave a powerful address containing these words: "Who are we that we should go to the kings of the heathen nations and attempt to deliver the people from heathen bondage? We have no authority from princes or from kings; we are not eloquent, we have no diplomatic finesse or chicanery, we are not men of address, and if we had all these things we should renounce all dependence upon them. But we rely on the presence of that God who said to Moses, 'Now therefore go, and I will be with thy mouth, and teach thee what thou shalt say.' God's presence is our hope, else we should say, "If 'Thy presence go not with us, carry us not up hence." He concluded by saying: "I Let us look to Christ -to Christ in all His love and mercy and mediatorial work. Let this ever dwell in our hearts. So shall we be cheered in every bereavement, and find ourselves at home in every clime. Farewell!"

On April 2 Ist, 1826, he and his partner and children, accompanicd by a party of friends, went down to Gravesend. He intended to sail by the Orwell, a ship in poor repute with seamen, on account of its inferior accommodation; but the captain was a religious man, and Dr. Morrison preferred congenial company to creature comforts. The vessel, however, was detained at Gravesend until May ist. As he was waiting to sail, he was greatly pleased to receive from his tried and proved friend, Sir G. Staunton, the present of a beautiful and valuable inkstand, which he acknowledged in these words: "I have received the beautiful inkstand which you have sent me, and done me the honour to inscribe with your own name. In China and in England you have for twenty years condescended, I may say (considering my humble circumstances), to favour me with your friendship. This last token of your kind regard shall be preserved in my family as a memento of your goodness to 
me. Accept, dear Sir George, of my sincerely grateful thanks for all your kindness, and for your substantial aid to the cause of our holy religion, through me, its humble servant. And accept of my best thanks for this parting expression of your 'affectionate' friendship. May the Divine blessing of God our Saviour rest upon you!"

He was accompanied to Gravesend by a number of old and tried friends. He says : "To-day, about eleven o'clock, a party of friends, Revs. G. and H. Burder, Townley, and others, knelt down and commended us to God's gracious care. From the room our ship, the Orwell, is in sight, and next to her another China ship, the General Harris, which will sail before us. In her Sir W. Fraser goes as passenger. $\mathrm{He}$ is an old acquaintance, and is to be our chief authority in the English Factory."

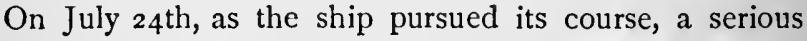
mutiny occurred on board. 'The men alleged they had been treated with harshness and tyranny, and some bold spirits had enticed their companions to swear an oath on the Bible to stand by each other. A plot was laid to resist the officers, and on the first pistol being fired at them it was arranged that every man should draw his knife and rush on his superiors, either to murder or overpower them. A consultation was called by the captain and officers, Dr. Morrison attending. Several pistols were fired, and, either by accident or design, one of them shattered the gunner's foot, which was afterwards amputated. Dr. Morrison asked and obtained permission to go and reason with the mutineers, and proceeding to the forecastle he spoke to them with combined firmness and kindness, until he persuaded them to obey orders and work the ship. They left the forecastle to disperse to their work, when one of the chief mutineers held an iron weapon in the chief officer's face in a menacing attitude. He was seized, tied up, and flogged; and three others who came to assist their :eader shared the same fate, and were then put in irons. 
There can be no doubt but that the composure and self-possession of Dr. Morrison on the occasion prevented much loss of life. As he fearlessly approached the angry nutineers they showed him no resistance, but listened with the utmost respect as he appealed to their better feelings, and urged them to return to their duty. He had great reward for his efforts in the conversion of one of the sailors. He says: "The gunner has been awakened to the most serious concern for the salvation of his soul, and is, I hope, a true penitent. I have visited, prayed with, and read good books to him daily, at his own desire. He has seen many wicked companions cut off in their sins, and, although he has lost a leg, blesses God that he was not shot dead on the spot. The blessed Saviour's full and free salvation, 'without works,' has afforded peace to his mind."

On August 8th the vessel anchored at Anjier, in the Straits of Sunda. Here the Rev. IV. H. Medhurst was waiting to see and confer with Dr. Morrison. He was labouring in Java amidst much discouragement. He chiefly went from door to door preaching Jesus to the Chinese and the Malays in their homes, but with small visible success.

On August 2oth, after a trying voyage of nearly five months, Dr. Morrison and his family landed at Singapore, and were hospitably entertained by Captain Flint, the brother-in-law of Sir 'T. Stamford Raffles. Here they stayed about a fortnight, and Dr. Morrison took the opportunity of ascertaining how far the plans put into operation by Sir T. S. Raffles and himself had been carried out. He was litterly grieved and disappointed at the result. He found that the large funds had been nearly all expended in the erection of buildings which were not half finished, while the Malayan professor was drawing his salary without attempting to discharge any duty. A huge tract of land granted by the late governor, and on which Dr. Morrison had laid out large sums of money, had been entirely neglected by the 
agent in charge of it, and the various measures taken by Sir Stamford to improve the moral atmosphere of the settlement had been allowed to fall into neglect. The work seemed to require entire reorganisation. Dr. Morrison secured the assistance of the Rev. Robert Burn, chaplain to the settlement, a man of piety and ability, and who entered warmly into the scheme. He became a trustee of the Institution, and manifested the deepest interest in its success. Dr. Morrison purchased at his own expense a portion of land near the Chinese quarter, to be occupied as a mission station. He proceeded with his family to Macao, and here experienced further disappointment. He found his house and furniture in such a state of dilapidation as to require the former to be virtually rebuilt, and the other to be renewed. His books also were found to be almost utterly ruined by white ants and other insects, which abound in Eastern climes. As quickly as possible he made arrangements for the comfortable settlement of his family, and then proceeded to Canton, entering upon his duties there in October.

Dr. Morrison wrote to the London Missionary Society a very cheering and interesting account of Leang Afa, whom he left in charge of the religious work of the Mission : "On September 6th we left Singapore, and on the evening of the Igth landed at Macao. All my former native domestics and my old Chinese teacher were waiting to receive me The next day the native Christian, Leang Afa, made his appearance, and in social prayer we returned thanks to God our Saviour for $\mathrm{His}$ kind preservation of our lives, and that our minds were still kept looking to Jesus. The following Sabbath I recommenced the religious services in which we formerly used to engage.

"Afa presented me with a small Chinese volume, containing explanatory notes to the Book of Hebrews, which he had composed during my absence. It is designed to communicate to pagans those views of religion which he derived 
from the late lamented Milne. I have read a part of it, and considering the few advantages Afa has had, the work evinces that he has made the Bible his study, although some parts of his composition receive a shade of colour in the phraseology from his recent paganism. He wrote also a small essay in favour of the Christian religion, which he entitled "The True Principle of the World's Salvation.'"

Leang Afa had been most faithful and diligent in the discharge of the important duties with which he had been entrusted. He gave a most interesting account of conversations he had held with his countrymen on the subject of religion. One of these took place in a passage boat. Afa happened to be reading the Evangelist Mark. A fellow passenger took up the book and cast his eyes over chapter ix., verse 9: "Till the Son of man be risen from the dead." The inquirer asked what the rising from the dead meant. Afa declared the death and resurrection of Jesus to make atonement for the sins of men, confessed his own faith, and preached salvation to all those who believed in His name. He spoke also of the miracles of mercy done by Jesus. His companion asked if he had seen these miracles with his own eyes. "No," said Afa, "they are related in the sacred books, which were published in the land of Judea, situated in the Western world, and many nations believed them to be true." "Have you never read," said his critic, "what the sage Măngtse said? - "It would be better for mankind to have no books than to believe everything contained in books.' Although the Western nations believe these books, it is not necessary that we Chinese should believe them. Do you believe?" To this Afa replied: "Although I never saw the things recorded, I most firmly believe the principles and doctrines contained in the Bible. I know that $I$ have been a very wicked man, and if there be no Saviour to make atonement for $\sin$ it would be impossible for me to escape the righteous judgment of God."

Dr. Morrison found also that in the hearts of others the 
truths he had imparted to them had taken firm hold, and especially so in the case of the person who first assisted him in writing out the Chinese New Testament for the press.

The gentlemen of the Factory at Canton gave him a cordial welcome, and, unsolicited, made a subscription in behalf of the College at Malacca, which amounted to upwards of five hundred pounds.

- Acting upon the instructions he had received from the Bible Society, he arranged for the Rev. W. H. Medhurst (afterwards D.D.), who was then at Java, to take a tour throughout the Indian Archipelago, visiting Borneo, Siam, and other places, to distribute copies of the Scriptures and various religious tracts and treatises. The Mission press at Malacca was kept busily at work for this purpose, and many thousands of pages of Christian literature were thrown off by it. Than Mr. Medhurst, no one more suitable for such work could be found; he had been ten years in the mission field, and had extraordinary knowledge of the Chinese language. 


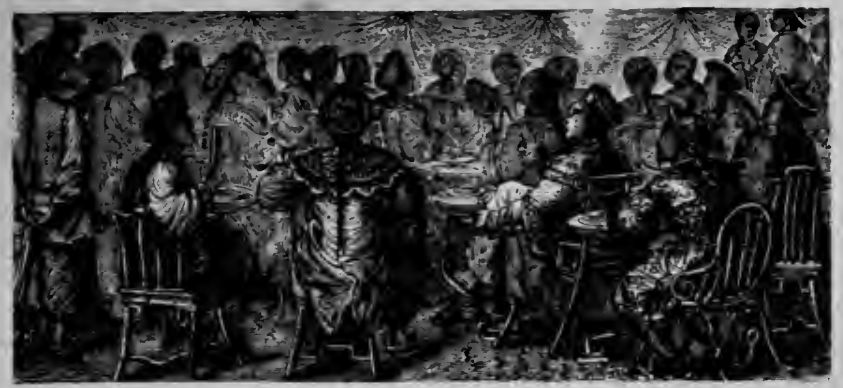

\section{CHAYTER NII.}

\section{LETTERS TO HIS CIILDRE.'}

"The true ambition there alone resides,

Where justice vindicates and wisdom guides;

Where inward dignity joins outward state,

Our purpose good, as our achievement great ;

Where public blessings, public praise, attend,

Where glory is our motive, not our end :

Wouldst thou be faned? have these high acts in view;

Brave men would act, though scandal would cnsue."

Young.

$\mathrm{H}^{1}$

ITHERTO, Dr. Morrison has been presented in these pages in his public character as a missionary of the Cross. The dignity and uprightness of his conduct, the unswerving conscientiousncss, and the untiring devotion to duty he ever displayed in his ministerial or literary labours, or in his service to the East India Company, have been abundantly illustrated. It is now needful to behold him in more private and tender relations, especially as manifesting the most affectionate concern and desire for the welfare of his children. Many letters are carefully preserved by his eldest and still surviving child, the Mary Rebecca to whom he refers in some of the cxtracts already presented. She and her brother, by being left motherless, drew out the tenderest sympathies of his nature towards 
them, and caused him to yearn over their spiritual welfare with a parental solicitude that was remarkable in its intensity. It was a rare thing for him to close a letter without seeking to impress upon them in some form the excellence of religion and the claims of the Saviour. Many admonitions fraught with sound sense and sagacity also flowed from his pen as he wrote to them, and in the light of these letters he appears to have combined in himself the most stern and unyielding adherence to principle with the most gentle and amiable graces of character. A few extracts will be alike instructive and interesting.

The following was written September 14th, 1824, when his son was at Mill Hill School :-

"It is gratifying to me that Mary and you feel interested in missionaries and the Madagascar boys, because Missions are the cause of God. And, my dear boy John, to please God, to think and say and do what He approves, is at once wisdom and happiness. I hope, Johnny, you and Bec have not forgotten one sentence of prayer taught you in China after mamma's death; it was this: 'Lord, help us to remember our mamma's instructions.' If you remember and act upon mamma's instructions, my dear Johnny, I am sure you will be happy, because mamma led you to God and to Jesus. May the Lord help you, my dear children, to seek His favour as the chief good.

"I hope, my dear, that you will advance in practical knowledge daily, and correct every succeeding day what you perceive wrong in your words or actions the preceding day. Consider that if Providence spare your life, you will have to provide for yourself by your own industry; therefore make good use of your time, and behave so as to ensure the confidence and respect of your friends and acquaintances. Above all learn to look to the Almighty to guide you, keep you from cvil, and bless you. God the Father, the Son, and the Holy Spirit desires the welfare of us all, but we must be willing and obedient to the 
voice of conscience, the strivings of the Holy Spirit, and the precepts of the Bible. May God for Christ's sake make you so.

"Within the last few days we have received by two different ships letters from the Straits, from Mr. Collie and from Bec, but not a line from you. This has given me and mamma uneasiness about you. If it were intentional not to write or mere neglect, it is still equally undutiful. You should remember how much we love you and are interested about you, and not do anything to grieve us. Be careful, my dear Johnny, of giving way at any time to pride and passion. Pride is one of the most heinous sins in the

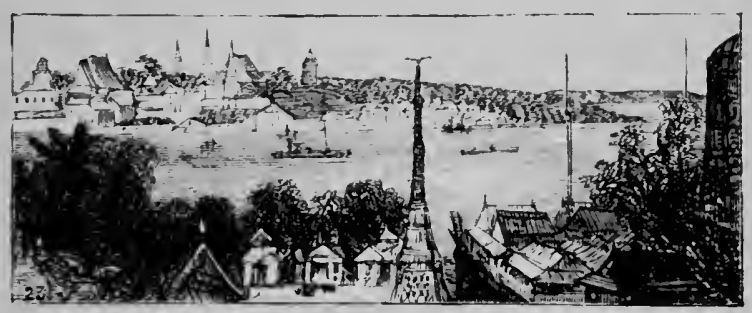

BANGKOK, SIAM.

sight of the Almighty. Make me happy, my belored child, by listening to a father's counsel, and not forgetting the law of thy mother."

In the year i 830 an opportunity came for Dr. Morrison's son to go to Sian, in connection with an Amcrican mercantile expedition, and his father wrote to him on the subject as follows: "I was not by any means, my dear son, displeased with your notion of going to Siam. At the same time it did not seem a judicious resolution, considering your youth. I was pleased, my beloved boy, to see your zeal, although I had other plans for you. But plans are often rendered completely useless by some subsequent uccurrence. To follow the leading of Providence is the 
best plan. If spared, it would be useful perhaps that you should see Europe again before you take a fixed position. But, on the other hand, you have your Bible and good European authors in every department of knowledge, and therefore, as long as health does not indicate the desirableness of a change and you have work here, I do not lay any stress on your early return to Europe. Don't fag too hard, and, on the other hand, don't be lazy. There is a medium. Take care of your health with religious care. Don't let pride and the ambition of scholarship drive you to excessive labour. Let the love of Christ constrain you to spend and be spent for His cause. Fear not, only believe as you are in duty bound the gracious revelation of Divine mercy to sinners. 'Ho, every one that thirsteth, come ye to the waters of life.' You thirst, my son? Drink then of Divine consolations, yea, drink abundantly-'whosoever will, let him take the water of life freely." "

His son was at this time at the Anglo-Chinese College at Malacca, and was engaged in important duties there, but it was now getting time for him to be preparing for a definite calling in life. His father therefore wrote to him: "I am very well satisfied that you have made yourself useful in the College, but you must ere long turn your attention to a profession for your subsequent support. You are too young to go to Siam. Indeed, I see no utility in people moving about from place to place. When we have work to do we should attend to it, and not leave it in search of what may be more amusing and interesting."

The following extract is 'excellent evidence of Dr. Morrison's intense desire for his son to become thoroughly versed in the Holy Scriptures :-

"I send one of Mr. Bagster's editions of the Bible in English, which he calls the Comprehensive Bible. One has gone to the College, and the copy I now send I intend for your own use. Read, my dear son, the very instructive introduction, and compare parallel passages, so as to make 
the Holy Bible familiar to your mind, and pray for God's blessing on your reading."

Towards the end of $183_{2}$ it was decided for John Robert to join the expedition to Siam and other places in the East, and reluctantly his father consented to the engagement. He wrote concerning it to his daughter Mary Rebecca :-

"It is now seemingly decided that your brother should leave us awhile, and go among perfect strangers and people belonging to other nations. I have hesitated much, but incline to hope that the course I have advised is best for him, considering his intended pursuits as a Christian merchant. I have advised his being a merchant with a constant reference to his being a merchant missionary, -i.e. one who makes all his pursuits to bear upon the diffusion of the Christian religion in these parts of the world. I trust he will not be less zealous nor less useful because he is an unpaid lay missionary. If Providence should spare his life and make him prosperous, he may not only be himself independent, but may be a blessing to all our family, and also to the heathen. May God preserve him in the midst of all dangers and temptations to which he may be exposed."

On the verge of starting on his journey the son received the following letter and rules of conduct from his anxious father :-

"As to your going I almost relent. I am afraid to trust you alone in such society. If you go the utmost vigilance and prayerfulness will be indispensable. God grant you grace to watch your heart and your tongue at all times. The Lord in mercy direct us in all our ways."

\section{"Rules of Conduct.}

“I. Mentally pray for Divine help in all affairs.

" 2. Converse but do not dispute with strangers and foreigners. 
"3. Read each document carefully through to get the whole sense before you interpret it, for reading a part only one may hastily give a sense that the subsequent parts alter or modify, and then it appears as if one did not understand the language and only guessed at the sense.

" 4. In difficult paragraphs consult if possible some native.

"5. Let important papers be well studied, and the English made as perfect as possible before delivering them in; therefore hurry is to be avoided. Set about them immediately, for procrastination occasions hurry at last."

As Mr. John Robert was accompanying the expedition in the capacity of interpreter and secretary, the force of these instructions will be readily recognised, and perhaps in them may be found the secret of both Dr. Morrison and his son's excellence as translators.

"January 1st, 1832. Another year has commenced its course according to our reckoning. The principle of halting awhile to review the past at any great interval of time whatever the reckoning may be a good one. The review of the past even in youth affords matter for sorrow and repentance and also for gratitude.

"How much more then would one think in old age! 'To be early instructed in the good way, and have an example set by parents, is a blessing, my dear John, for which you and your sister have to be thankful. May the Lord strengthen in your soul every good resolution, and through faith in Jesus give you the victory over every spiritual foe. Look to Jesus! He is the Captain of your salvation. Join His standard, declare for his cause, and put yourself entirely under His orders and His protection. Halt no longer, my dear son, between two opinions. Give yourself to the Lord and to His Church unreservedly."

'That 1)r. Morrison's repeated and earnest exhortations to his son to seek and follow the Lord fully were not without avail is shown by a passage occurring in a letter under date November $23^{\mathrm{rd}}, 1 \delta_{32}$ :- 
"I am glad you have come to the resolution, God helping you, to avow yourself a humble dependant upon the Saviour's death by commemorating the same and showing forth His death till He come."

The following letter, under date September 6th, I 833 , shows that in the earlier as in the later days of Christian Missions a Sadducean spirit was abroad, grudging the money spent, and heartlessly criticising those who were bravely doing their best, although hemmed in by difficulties:-

"Reform and economy seem to have engendered a heartless spirit of severity and suspicion often bordering on malice. The Christian Advocate, a rather talented paper, has week after week filled its columns with attacks on the London Missionary Society, in a most unchristian manner. The Directors have no doubt erred; but who is perfect? The repudiated bad missionaries have all assailed them under the generalship of a Mr. Forbes. Grace and pence be with you, my son. Oh, keep your heart in the fear of God with all diligence! Neglect no means; enter not into temptation; seek not the approbation of the wicked ; imitate them not. Be simple and unaffected, but be not afraid of appearing singular."

I)r. Morrison was most anxious that his son should be engaged in mission work, or that he should qualify himself for a life of usefulness in some relation in China. So he wrote to him under date September I2th, I 833 : "Remember my advice to speak Chinese as much as you can till you are quite fluent, and study a more audible elocution at all times. I also recommend to you what I never had time to do myself, but now regret it. Make a collection as they occur of pithy good sentences in all languages, that you would like to adopt as your own. 1)o so first in a sort of 'waste book' without order, and if you have time hereafter you may arrange them under heads. Farewell, my dear son; God bless you, and make you a blessing to your family, your kindred, and all with whom 
you have to do. Not only do no evil, but ever study to do good. Let the love of Christ constrain you."

His letters abound in brief, sententious, and important scraps of advice, which we may well believe were carefully treasured up by his children. The following are taken almost at random from a pile of letters addressed to them :-

“ In your note you say, 'in haste.' Don't get into a habit of making this apology or indeed any other in letters. Say the best and the most you can, and let it pass. I mean this as a good general rule."

"Your remarks concerning the hostility to the Morrisons in certain quarters are, I fear, too true. At the same time, the other party are not what could be wished in respect of religious sentiment and Christian morality. We can be of no party which is against ' the truth ;' we must ever be for the truth, and therefore cannot be acceptable to those who reject the truth of the Gospel."

"Keep short accounts, my dear son, in the books entered on high. Every day settle carefully your private memoranda. Presume not on to-morrow. When I first came to China, I prayed three times a day ; I implored God's protection only for a few hours, from morning till noon, from noon till evening."

One more extract from a letter written on board the Hercules at Lintin, after bidding farewell to his wife and younger children, will further illustrate the tenderness and depth of his domestic affection :-

"Yesterday morning at daylight I watched the Inglis conveying you out of sight, with many tears and much prayer to God for you, my beloved wife, and our dear, dear children. John went to Macao to get me some clothes before I start for Canton. I am shut up in the cabin where you all slept the last few days. I have a Bible, however, and the 'History of the Sufferings of the Scottish Covenanters, in which I find great consolation. I hope the 'sweet presence' of the blessed God is with you this day. 
"John has communicated your last message. By the pilot you say, 'Every one seems kind on board.' Thank God! I heartily and humbly bless the Lord that $\mathrm{He}$ has mingled much mercy with this trying occasion, especially in 'raising up kind friends.' I purpose to give myself wholly to Chinese, and especially, as I before resolved, to the Bible. I should like to print an edition at our own press. May the Lord prosper the work of my hands."

It will be seen, in subsequent pages, how well both of these children seem to have absorbed the precepts thus instilled into them, and how fully his earnest prayers for their welfare were fulfilled.

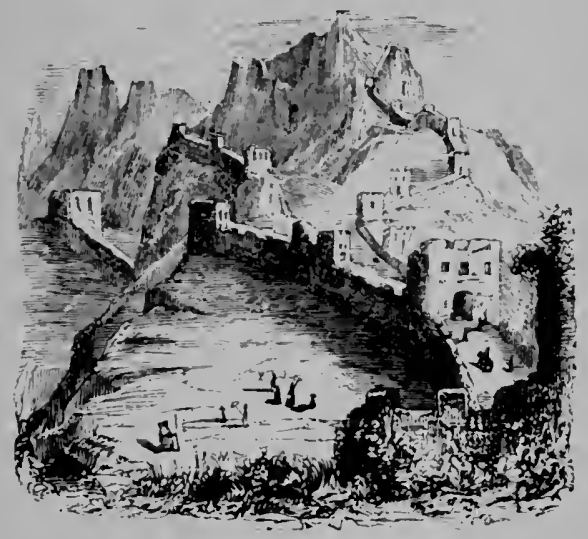




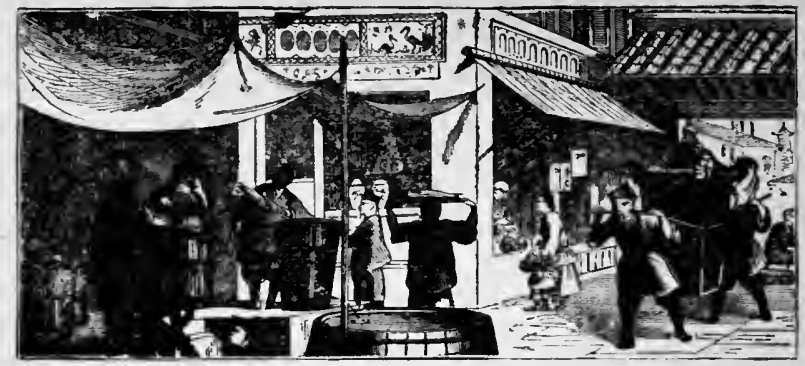

CHAPTER XIII.

RIENEWED LABOUR.

"There is a book

By seraphs writ with beams of heavenly light, On which the eyes of God not rarely look, A chronicle of actions just and bi ight."-CowPER.

R. MORRISON speedily settled down to his various duties and engagements in his chosen sphere. He spent half the year at Canton in attendance at the Factory, as his official duties required, from the arrival of the Company's ships in August until the last was despatched in February or March ; and then he went to Macao to rejoin his family. He had a busy life. He commenced the gigantic work of preparing a Commentary on the Bible in Chinese, and laboured at it with all the marvellous patience and assiduity of which he was capable. He conducted public and private worship with as great frequency as he could induce either Europeans or Chinese to attend, and he was in daily demand when in Canton to execute commissions for missionaries and friends at Penang, Malacca, Singapore, and many other places, who were obliged to send to Canton for domestic articles of nearly all kinds. Then he had to obtain all printing materials, books, teachers, and workmen, and keep all in active employment. Missionaries on the 
other stations in the Fast applied to hin for advice and direction in every matter of difficulty or intricacy, and his long experience and excellent judgment made him an invaluable counsellor on every question of Eastern mission work.

He was much hampered also by adverse criticism from those who had little sympathy with Christian Missions, and by the superciliousness of some in the employ of the East India Company, who, while willing to avail themselves of his services as an unrivalled Chinese scholar, were yet disposed to scoff at him as a Christian advocate, and who, whilst making large fortunes out of the commerce carried on with China, could not be brought to aid in the attempt to enlighten the natives by the truth. Dr. Morrison says in his journal :-

"I have been reading on 'beware of covetousness' (Luke xii. I5). Covetousness implies discontentedness. I thought of preparing an English sermon from those words, but I am afraid it may be too pointedly applicable to those who may be my hearers.

"I met this morning with this little Chinese story: Hooshaou was a very poor man, yet he daily thanked Heaven for pure bliss. His wife said to him, "We have daily only three meals of greens, rice, and water. What do you call pure bliss?' He replied, 'Happily we live in times of peace, and experience none of the miseries arising from conflicting armies; happily there is nobody in our family that suffers from hunger and cold ; and happily none of us are laid on a bed of sickness nor immured in prison: if this is not pure bliss, I know not what it is.' 'Though this is a pagan story, I think it a very edifying one. We have to thank Heaven for all that Hoo-shrou had and a great deal more."

Christian sentiment in England at this time on the subject of liberal giving to the cause of God was not very elevated. Dr. Morrison published a tract entitled "Christian Devotedness," in which he urged strongly the propriety of all property 
and riches being considered as from the Lord, and to be used in reference to $\mathrm{Him}$; in fact, of being devoted for Him and to Him. The Eclectic Revieze fiercely criticised the production, and said the man who wrote it could have no children and no living mother. Concerning this, Dr. Morrison says: "But I have a wife and children,and yet I am a good deal of an anti-earth-treasure-hoarder. But my principles go to 'lending to the Lord '- ' $\mathrm{He}$ will provide.' 'Yes,' say the others, 'by your instrumentality;' and so carping and caring becomes a duty imposed by Providence. 'Jehovah-jireh,' says the Bible. 'Yes,' says the commentator; ' the Lord will enable you to provide; you are not to look beyond yourself for any provision.' Now, I ask, does not this reasoning convict itself? for, trusting Providence, according to it, only means trusting to one's self; and the word of God is made just to mean nothing at all."

About the same time also the Quarterly Revieze made an attack upon him as to the imperfections of his translation of the Bible. It taunted him with being "self-instructed," and that his "humble pretensions in any other case should have disarmed criticism." It also severely blamed almost every step hitherto taken by the Bible Society. It was a needlessly cruel attack. No one was ever more ready to adnit the drawbacks of his translation than was Dr. Morrison, and all he ever professed to have done by it was to have laid a foundation on which others could build a more perfect superstructure. He felt this attack, therefore, most keenly, and wrote a reply to it, which was not published, but contained the following paragraph: "What good scholar ever existed who was not in a great degree 'self-taught'? ... But putting this aside, who was to instruct the modern missionaries in Sanscrit, or Chinese, or Otaheitean, but the individuals themselves? There had been regularly educated civilians and commanders, and chaplains, too, in India, and commercial agents in China, long before the English missionaries were born; but had they learned or had they 


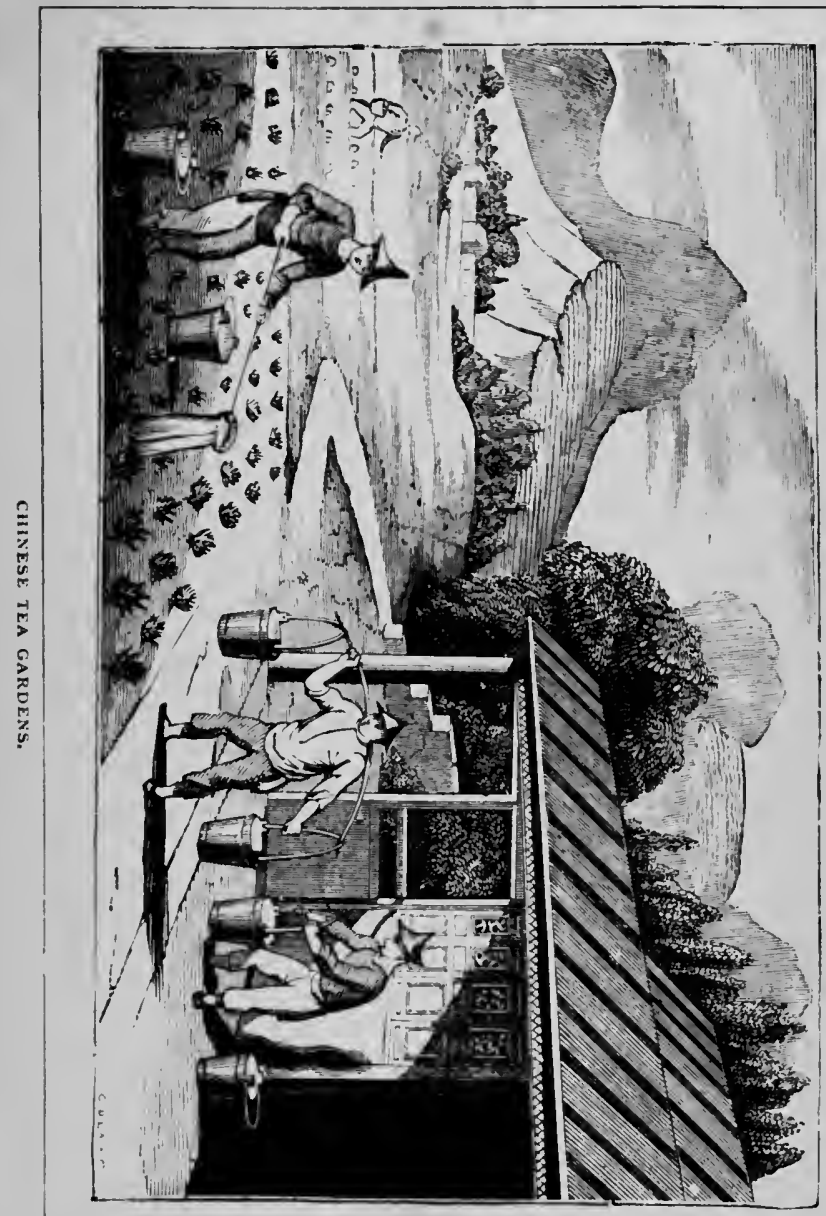


provided means to teach those languages? England had drunk Chinese tea, and raised millions of revenue from it, for a century; but England had not furnished one page, nor established a single school to teach Chinese, till a "selfinstructed 'English missionary did it."

Such a reproach came with ill grace from a periodical which at the very time was edited by a man who, however much to be condemned for narrowness and asperity of spirit, was yet greatly to be commended for having raised himself from a shoemaker's bench to a high position in scholarship and authorship.

As the East India Company was without a chaplain in Canton at this time, and usual prayers were therefore not read on the Lord's Day, Dr. Morrison offered to read the prayers and preach without any pecuniary reward until another chaplain could be obtained. He stated that unwillingness to see public worship discontinued was the sole reason of his offer. He received the following answer from Sir W. Fraser, the President of the Select Committee :-

"I have mentioned to my colleagues the purport of your note, and they coincide in opinion with me that we are not authorised to accept your kind offer, which I am well assured was only made from the best motives and wishes for our welfare." Dr. Morrison remarks : "It is a lamentable state of religious or irreligious feeling, that, in the true spirit of Popery, under no circumstances (except reading prayers over the dead) will they have communion with any who will not bow down to absolute authority, and yield an inplicit uniformity. If such persons 'believe,' they don't act upon the article in the Creed, 'communion of saints.'"

Under these circumstances a European gentleman offered his room to Dr. Morrison, and collected as many as he could for Divine service. About twenty attended, and very refreshing spiritual meetings were held.

He was also able to gather a small company monthly to pray for the conversion of China. The Chinese converts 
or inquirers, with about seven Europeans, were united in this first missionary prayer meeting in that great heathen nation. Every one took part, giving out a hymn, reading the Scriptures, or offering prayer. This meeting was frequently a great refreshment to Dr. Morrison's spirit when he was tempted to despondency.

At the beginning of 1827 a fire occurred in his neighbour's rooms at Canton, and burnt into his apartments. All his books and many valuables were destroyed or rendered useless. A friend comforted him by saying it was a judgment upon him for being so vain of beautiful bindings.

A new periodical, called the Canton Register, was commenced, to circulate in the British settlements of the East. It was chiefly a commercial paper, but Dr. Morrison was asked to contribute to it regularly, and to this he agreed on the condition that he should be fully at liberty to express his opinions on the moral and religious subjects it was the olject of his life to promote. This opportunity was granted him, with an offer of three hundred dollars a year to be bestowed on any benevolent institution he chose. 'To this paper he contributed frequently till his death.

Dr. Morrison was destined also to experience much disappointment through the failure of two institutions he had been the principal instrument in establishing. The Language Institution was dissolved in England for want of an enthusiastic spirit to keep it alive. But indeed it was before its time by fifty years. Then the Singapore Institution also failed entirely through the mismanagement of persons who were entrusted with the carrying out of the project. Thus the benevolent intentions of Dr. Morrison, who had spent about six thousand dollars upon it, and of Sir T. Stamford Raffles were frustrated. On the other hand, he was cheered by the success of the Anglo-Chinese College at Malacca; and the Select Committee of the East India Company drew up a memorial to the Honourable Court of 
Directors in England, setting forth very clearly the good it was doing, and the excellent influence it was likely to exercise on the interchange of commerce between the nations, by facilitating intercourse with China and extending to Europeans the knowledge of the Chinese language. The memorial, which was signed by Sir WV. Fraser, the chief of the Factory, and the other members of the Committee, adds : "It is but justice to Dr. Morrison to state that the College entirely owes its origin to him, and its continuation to his exertions; and he has thus added to pre-eminent success in Chinese literature his unremitting exertions for the diffusion of useful knowledge."

In December, 1827 , he experienced a great loss in the death of his firm and helpful friend Sir W. Fraser, the chief of the British Factory. He died after a month's illness, and was buried in the Honourable Company's burialground at Macao, Dr. Morrison conducting the service. $\mathrm{He}$ was taken ill when preparing to return to England, and the ship which was to have conveyed him fired minute guns in the Roads at the time of the funeral. Sir William was forty years of age, of ample fortune, and one of the few British residents in China who befriended missionaries. His funeral was attended by the judge of Macao, and all the Europeans who were resident there.

So carefully was Dr. Morrison observed by the Roman Catholics on the one hand, and Chinese officials on the other, that he was entirely shut out from preaching or teaching the Gospel to any, save the few Chinese in his own employ, and occasionally one or two who might be induced to join them. He was therefore compelled, almost exclusively, to make attempts to reach the heathen through the press, and for this purpose he laboured incessantly and devotedly. $\mathrm{He}$ persevered in the preparation of his Chinese Commentary ; and, in order to train native inquirers into clearer views of Divine truth, he prepared a system of reference to each book, chapter, and verse of the Bible, with chrono- 
logical, historical, and literary notices. He also commenced a Dictionary of the provincial dialect of Canton, which was then coming into use almost equally with the Mandarin dialect. He employed many means of disseminating the Bible and religious tracts, and succeeded in sending large quantities to Corca, Cochin China, Siam, the islands of the Archipelago, and, by means of traders, into the very heart of the interior of China.

The native teacher, Leang Afa, meantime laboured assiduously for the benefit of his countrymen, as opportunity permitted. He went up the country and opened a school, instructing a few children and his own family in the principles of Christianity. He wrote from thence to Dr. Morrison:-

"The people are all deceived and sunk in stupidity respecting vain idols. Although I take the truth and exhort them, all my strength is too small to overcome such a multitude. At present, during the seventh moon, the Buddhists deceive the people by the rites of the $\mathrm{Yu}$ lan shing hwuy. Every family, without exception, asserts that it is absolutely necessary to exert their utmost strength in burning multitudes of paper before the tablets of their ancestors, and also burn some in the streets, that destitute ghosts coming and going, as well as the spirits of their ancestors in Hades, may receive these things, and have clothes to wear and money to spend in the other world. If these things be not done, the hearts of the people are unhappy; not to do so is considered a want of piety and affection and virtue. When I look on such stupid nonsense I am exceedingly grieved, and at a loss what to do. I can only meditate and attend to my own conduct night and day, carefully and firmly adhering to the truth, and look up and pray to the Lord on high to convert the hearts of men, and turn their feet into the straight road which will lead them from everlasting misery."

A curious testimony as to the value of Dr. Morrison's 
literary labours occurred at this time, being nothing less than the translation of his enormous Dictionary into Japanese. He was also informed that the prevailing

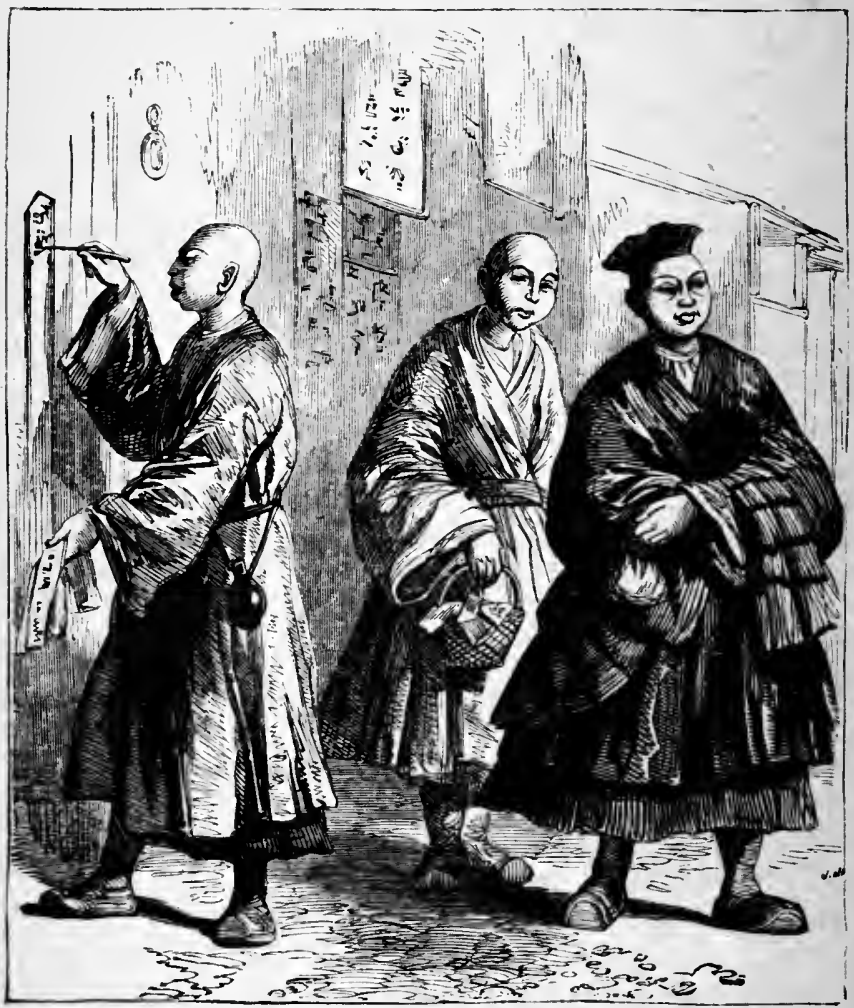

BUUDHIST PRIESTS IN CHIXA.

fashion in Japanese fans was to have them covered with extracts from: the Dictionary, arranged alphabetically, and written with extraordinary neatness.

At the close of the year 1828 he was called to attend two young officers on the ship Orzeell, by which he had come 
out from England after his visit, and who both died after a short illness. He showed them the most tender and careful attention, and was rewarded by both of them giving satisfactory testimony that the truth and comfort he imparted, in the name of Christ, had been blessed to the salvation of their souls.

Dr. Morrison writes thus concerning their end :-

"The Moravian surgeon has just been here to say that his patient, Johnstone, whom I have visited twice to day, has departed this life. There was hope in his death. His neemory supplied him richly with sentences from the prayers he had been accustomed to pronounce. On leaving the last time, I took his death-cold hand and said, "The Lord be with you;' he replied, 'And with thy spirit.' IVilson is fast sinking. Both he and Johnstone were in high health a month ago, and wcre both at three great parties at Whampoa, where they feasted without fear. Johnstone gave signs of earnestly pleading for mercy. Wilson is silent almost, although he joined with uplifted eyes and clasped hands in prayer to God with me. Oh that men were wise! that they would consider before the last hour! 'The $L$ d help us to live devoutly, and with minds so blessed as to look on death as a real gain to us."

The Sunday evening meetings previously referred to continued, and grew in interest and importance. Dr. Morrison says of them, under date January ist, I 829 : "The union which takes place in my room at Canton of pious books and pious persons of all countries, sects, and creeds often excites my admiration and gratitude."

On this date the gunner on board the Oravell called to thank him for the kindness and instruction he had received from him when he had his leg amputated after the mutiny.

Dr. Morrison next appears as the saviour of an innocent man from the hands of the executioner. The captain, crew, and passengers of a French vessel bound to Manilla, when within a short distance off Macao, were all, save one, 
murdered by a number of Chinese, whose cupidity had been excited by the treasure on board. The survivor supported himself on a plank, when he was taken up by a fishing-boat, and brought to Macao. He deposed to the axful crime bcfore the Portuguese authorities, and information was forwarded to the Chinese officials at Canton, who directed that prompt measures should be taken for the apprehension of the murderers. They were traced, captured, tortured, tried, and condemned to be executed; but before being so, they were brought to Canton to be confronted with the survivor of the murdered crew. The ceremony took place in the Hong Merchants' Hall, and was attended by many forcigners, among whom Dr. Morrison occupied a front position. 'The murderers were displayed in bamboo cages, so small that they could not sit upright; they had fetters on their necks, legs, and wrists, and on each cage was inscribed the name of the offender and the sentence passed upon him. The French sailor recognised most of them, but last of all one man was brought forward who attracted genèral attention. He was an interesting-looking man, about fifty years of age, and the name Tsae-Kung-chaou was on the cage. He attempted to address the Court, but. was unable to make himself understood. None of his own countrymen present could interpret for him, as he spoke the Fôkien dialect, which differs widely from the Canton. Dr. Morrison therefore went forward and conversed with him, and ascertained that he was unjustly condemned, and was quite innocent of any share in the awful crime. He then addressed the Court on behalf of the man so forcibly, that he was remanded until proper inquiries could be instituted, with the result that in a few days the man appeared at Dr. Morrison's house to express his fervent gratitude to him as the preserver of his life. The resident Chinese were loud in their praise of an Englishmmn who thus pleaded so earnestly for the life of one of their countrymen.

Mr. Chinnery, a very talented artist who was then in 


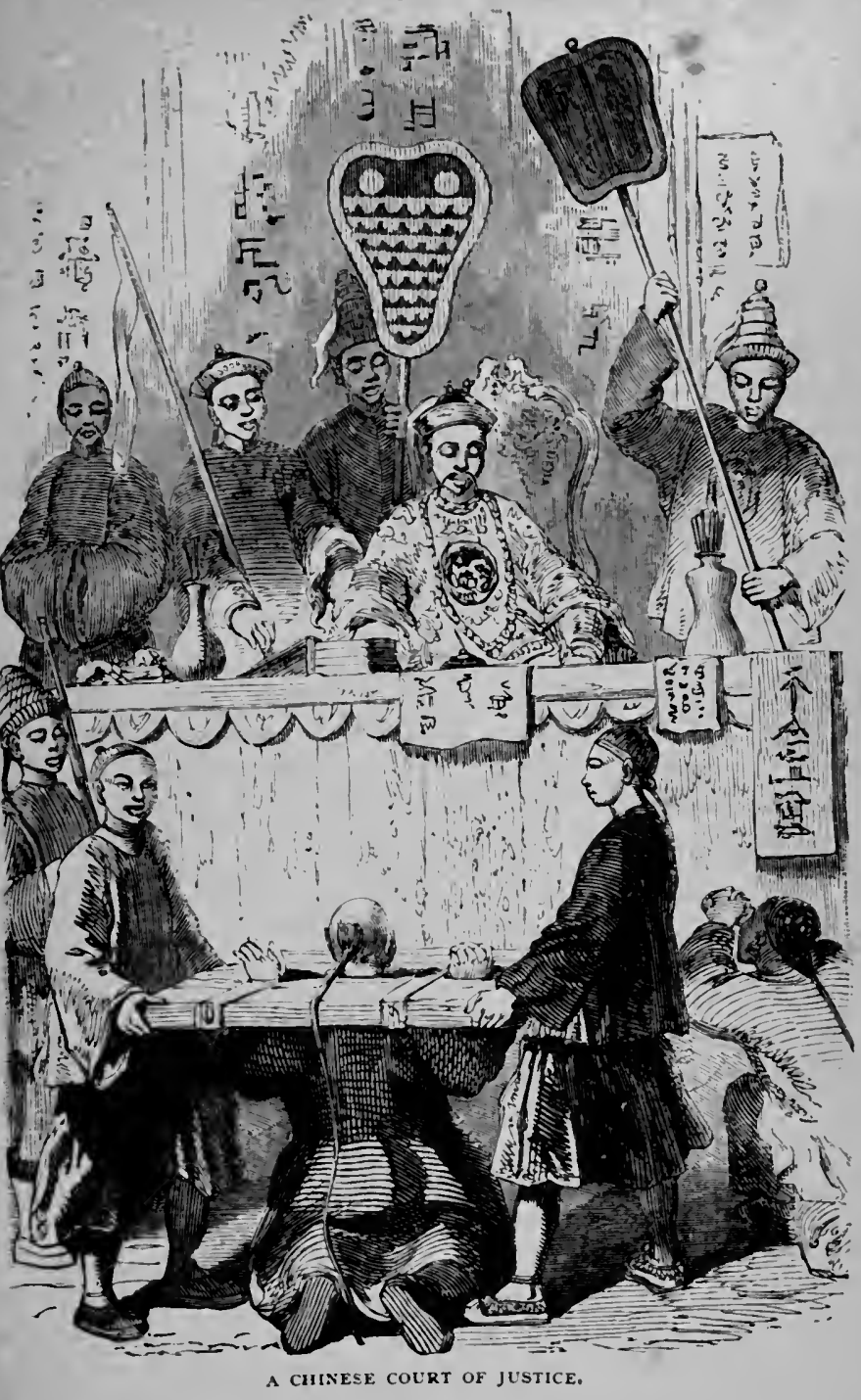


Canton, painted a most excellent portrait of Dr. Morrison, with two of his Chinese assistants, which was engraved at the expense of the gentlemen of the Factory, in testimony of their esteem for him, and impressions of the picture were sold for the benefit of the College at Malacca (see frontispiece). An attempt was made to establish at Macao a "British Museum in China," for the purpose of collecting native and foreign curiosities, including productions of art, of natural history, etc. ; and Dr. Morrison entered into the scheme with his usual earnestness and generosity. He also, with a view of promoting the study of Chinese literature and language, commenced a weekly reunion in his own house of students of the language and their teachers, topics for conversation being arranged previously, papers being read on subjects relating to books, idioms, and dialects, and curiosities of all kinds being brought for general inspection.

He finished, in March, 1829, the third part of his Dictionary of the Canton dialect, and then busied himself with other literary work bearing on the diffusion of Divine truth. Leang Afa had recourse to him at this time. He had been obliged to break up his school, and flee from a persecution which had threatened his life, on the charge that he was disseminating a wicked superstition, and seeking to sell his country to foreigners. He was obliged, therefore, to take refuge at Macao with Dr. Morrison.

The duties of Dr. Morrison at the Factory now became more arduous and offensive. They had always been uncongenial, but he had faithfully and diligently discharged them, because only thus had he preserved a foothold in the country, and been able to pursue his mission work without receiving any recompense from the Missionary Society ; but since the death of Sir W. Fraser persons had come into power who sought to exercise an authority over him more arbitrary than he could bear. He resolved, therefore, to resign his office, and devote himself to higher work, although it might necessitate his confining hiniself to Macao cr 
Malacca. With this view he wrote a letter to the Select Committee, giving up his position. Very suddenly and unexpectedly a change was made in the Executive of the Company, and a gentleman-Mr. J. F. Davis-was afterwards appointed as chief, who proved a firm friend to the missionary.

Leang Afa left him in December to go and print two tracts which he had prepared, and by which he hoped, as his school had been broken up, to circulate a knowledge of the Gospel. Dr. Morrison says of him: "His prayer in parting was very appropriate, and shows clearly that his heart is in his work, as well as that he is in the habit of praying. He desires the prayers of God's people that he may be faithful till death. May the Lord bless him and make him a blessing."

In the beginning of 1830 Dr. Morrison had the happiness of baptising another Chinese, and receiving him as a member of the Church. This was Kew-a-gong. Until his introduction to Dr. Morrison he had led an idle and improvident life, neglecting to provide for his wife and children, whom he had entirely forsaken, and not settling to any regular occupation. But from the moment the truths of the Gospel touched his spirit he became as anxious for the happiness of his family as before he had been careless of it. He learnt the art of printing from Leang Afa, and worked diligently at it ; meantime receiving instruction from Dr. Morrison, until he manifested steadfastness and sincerity sufficient to justify his baptism as a believer in Jesus. After being baptised he became the companion of Leang Afa in the distribution of the Bible, religious books, and tracts.

Dr. Morrison had made very pressing appeals to the American Board of Commissioners for Foreign Missions to send agents to China to aid in the work of diffusing the Gospel. He was greatly cheered to learn that in response the Rev. David Abeel was being sent out as chaplain of 
the Seamen's Friend Society, to labour for sailors frequenting the ports of Canton, with the understanding that after one year he was to enter the service of the American Board for the purpose of exploring the islands and countries in Eastern Asia to find out the best stations for foreign missions. He sailed for Canton October $\mathrm{I}_{4}$ th, 1829, in the ship Roman, accompanied by the Rev. E. C. Bridgman, and reached the Flowery Land in February, 1830 , where he and his companion received a warm welcome from Dr. Morrison. $\mathrm{He}$ at once furnished them with books for the study of the language, procured a teacher, and gave them personal help and instruction. The American Board most gratefully acknowledged his kindness to them, and most warmly did he rejoice that at last he had fellow-labourers in the field, and that now it was likely that, though he should be shortly removed, there would never cease to be earnest witnesses for the Gospel of Christ in China.

He had also the joy of receiving in Canton his eldest son John Robert, who, in Fngland and at the Anglo-Chinese College at Malacca, had been diligently pursuing his studies for some years. He was only sixteen years of age, but he had become so proficient in his knowledge and use of the Chinese language that he received the appointment of translator to the British merchants in. Canton.

Dr. Morrison was not allowed to proceed for any long period in his work without being assailed by some calumnious or offensive criticism. Towards these he generally maintained a patient and silent reserve, satisfied with the purity of his motives, and believing that time would preserve his reputation from any ultimate misunderstandings. A French philologist of eminence, M. Klaproth, in the year 1830, proposed to a gentleman in the Company's service, who was afterwards Chief Superintendent of His Majesty's Commission in China, that he should become the enemy of Dr. Morrison, in which case he undertook to laud him in the public press. Mr. J. F. Davis, the gentleman in 
question, was celebrated as one of the most learned men of his day in Chinese literature as well as IVcstern erudition, and he had a heart as honourable as a mind well informed. He returned the following answer to this insiclious offer :-

"I cannot help regretting that you should indulge in such hostility to Dr. Morrison, concerning whom I must declare (and I could not without the greatest baseness do otherwise), that I agree with Sir George Staunton in considering him as 'confessedly the first Chinese scholar in Europe.' It is notorious in this country [England] that he has for ycars conducted on the part of the East India Company a very extensive correspondence with the Chinese, in the written character; that he writes the language of China with the ease and rapidity of a native; and that the natives themselves have long since given him the title of 'Le Docteur Ma.' 'This testimony is decisive, and the position it gives him is such, that he may regard all European squabbles concerning his Chinese knowledge as mere Batrachomyomachia, battles of frogs and mice."

The year $183 \mathrm{r}$ opened with the happy tidings that Leang Afa had baptised three persons. 'These were a father, in his sixty second year, and his two sons, one twenty-two and the otler seventeen. The father was a man of good education, and his sons had been hitherto employed in native literature. The son of Leang $\mathrm{Afa}$ was placed under the care of Mr. Bridgman for instruction in the English language and in Christian truth.

Up to the present time the English Government of Penang had made an allowance of one hundred dollars a month to the Anglo-Chinese College at Malacca. This was now withdrawn in connection with a system of retrenchment carried out by Lord W. Bentinck. The Select Committee of the East India Company at Canton, with its usual liberality, at once made a grant of an equal sum, under "the firm conviction of its excellence," saying, "We believe 
it to be eminently calculated to diffuse the light of knowledge and of useful instruction through the most remote possessions of Great Britain, and to assist in removing those prejudices which have so long fettered the public mind in this country."

Another missionary, to the joy of Dr. Morrison, now arrived at Canton from America. This was the Rev. Edward Stevens, who came in a vessel named the Morrison, after the subject of this memoir. Its owner was Mr. Olyphant, a devoted Christian and a faithful friend to the missionary, who opened his factory in Canton for Christian worship and service at any time.

Dr. Morrison's "Domestic Instructor" and "Scripture Lessons" were now printed and published. He himself gave two hundred pounds towards the printing of the former, which was issued in four octavo volumes. 'The two works were intended to afford a historical, doctrinal, and practical view of the Christian religion, and they were widely circulated by the agents now being employed for that purpose.

$\mathrm{H}$ is generous sympathies were daily aroused towards all cases of individual necessity and of public objects of benevolence. The claims on his practical liberality were endless, nor were any refused that seemed to merit assistance. Especially his desires were drawn out towards the Finglish sailors, who, when at liberty from their duty on board ship, became the victims of Chinese land sharks, who supplied them with distilled spirits, rendering them liable to shameful extortion, and exciting them to riot and outrage. In order to do something to preserve such from over-indulgence and robbery, Dr. Morrison engaged a respectable native to take charge of a "coffee shop," and had handbills printed inviting sailors to partake of the cheap and refreshing beverage provided for them there, and warning them against the poisonous and fiery liquids sold by the natives for the purpose of rohbing them.

He gave the English service on the Lord's Day into 


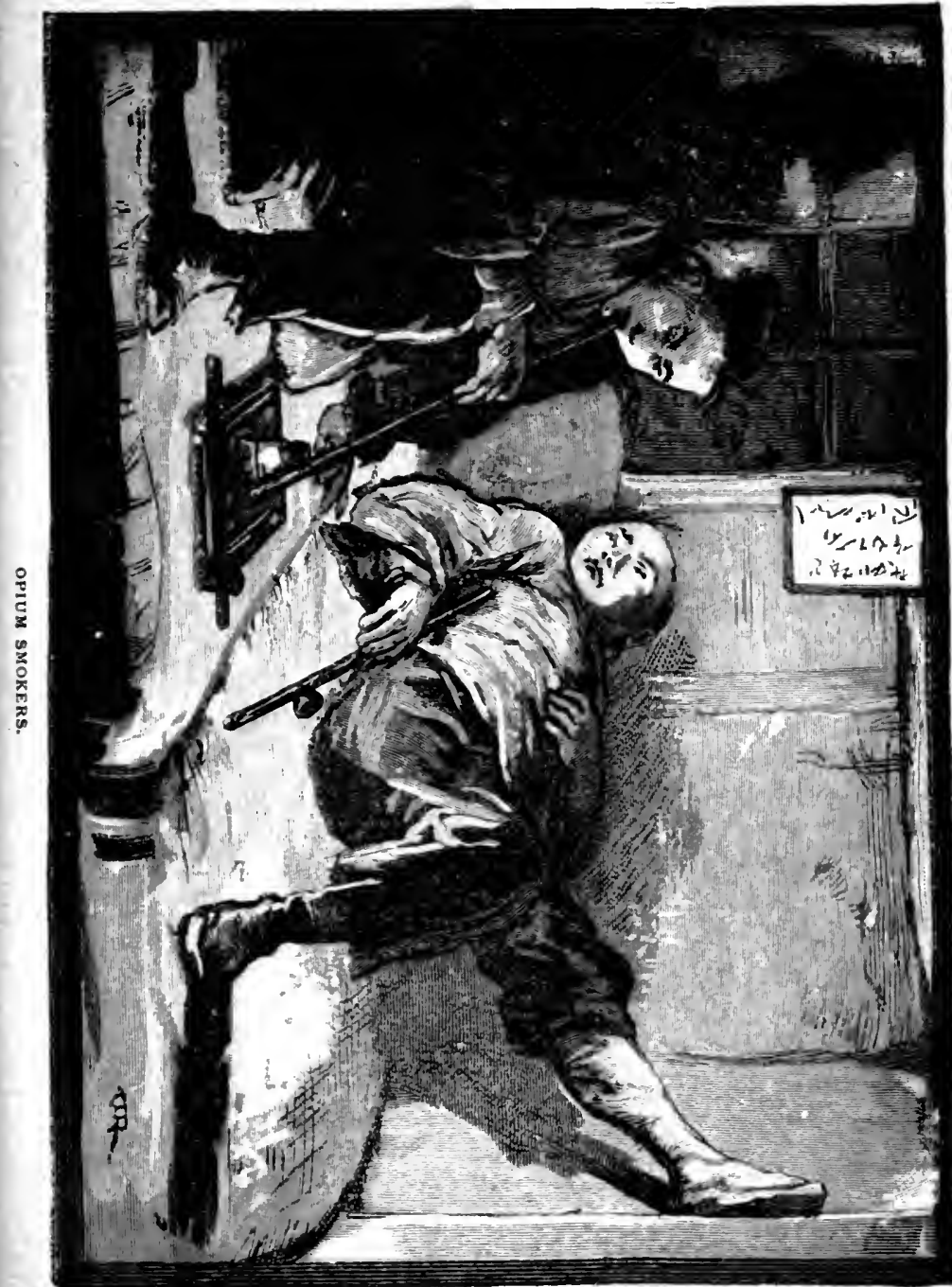


the hands of Mr. Bridgman, and devoted himself to the Chinese. He was greatly cheered in having to baptise the Mandarin teacher at the Anglo-Chinese College. His name was Choo-sëen-sang, and he had been an earnest student of the Christian system for a long time, but had for a period resisted conviction on account of opium smoking. At length he was able to break off the habit, and professed to believe with all his heart in the Lord Jesus. In his testimony he stated that he believed Jesus to be the Son of God, that he believed what $\mathrm{He}$ taught, obeyed what $\mathrm{He}$ commanded, and hoped for what He promised." In sailing from Malacca to Canton he had been nearly shipwrecked, and thus was led to see his wickedness in not professing Christ, after he had become convinced of His truth. Leang Afa also had the happiness of baptising several others, making seven in all who had professed conversion through his teaching.

At the beginning of $183_{2}$ Dr. Morrison wrote :-

"There is now in Canton a state of society in respect of Chinese totally different from what I found in 1807 . Chinese scholars, missionary students, English presses, and Chinese Scriptures, with public worship of God, have all grown up since that period. I have served my generation, and must-the Lord knows when-fall asleep."

A very important change in his prospects was now threatening. The charter of the East India Company in China was soon to terminate, and the condition of all in the English Factory at Canton would be greatly affected thereby. No one more so than Dr. Morrison. He had served the Company twenty. years, and the Select Committee had spontaneously sought to induce the Court of Directors to grant him a pension in consideration of the important services he had rendered. To this appeal no answer was made, and he had, therefore, before him the alternative of either seeking some secular employment, or of having recourse to the Missionary Society, to which he had given such splendid gratuitous service for the period 
in which be had been employed by the Company. $\mathrm{He}$ resolved to wait the unfolding of the Divine will, but of the two paths undoubtedly to choose the latter, in order that he might still devote his powers to the evangelising of the heathen. To the uncertainty of his pecuniary position was added also the sorrow of being separated from his family. The health of Mrs. Morrison had for some time been poor, and a voyage home was necessary for her restoration. And to crown his anxieties at this time, he received a letter from the Select Committee of the East India Company inforning him that the Portuguese governor of Macao had been appealed to by the Roman Catholic dignitary of the diocese as to some of his publications, which were alleged to be opposed to the Romish faith, and stating that the use of a printing-press was prohibited in the Portuguese territories, except under previous censorship, and that the press must be discontinued. The Select Committee, therefore, requested Dr. Morrison to suspend the issue of any further publications from the press at Macao.

This was an ungenerous and annoying act of intolerance; but as there was no appeal from the decision, Dr. Morrison had to content himself with offering a strong expostulation, and to obey. Still he did not abate any encrgy in the circulation of the many publications from the pens of himself, Dr. Milne, Leang Afa, and others, which were now extensively distributed, and many of which had penetrated as far north as the ancient wall. He devoted himself with increasing zeal to preparing his Commentary; he continued his public service on Sabbath mornings; and, as the habit had sprung up in Macao among the foreigners of spending the Sabbath evening in recreation and amusement, he strove to draw them to a higher enjoyment by commencing an evening lecture. At the close of the morning service for the foreigners he conducted one for the Chinese. In this he ever took great delight, never omitting the singing, although 
he often had it all to himself. In the intervals of worship he was occupied in reading, or in hearing his children repeat hymns and Holy Scripture. At these times he used to resort to a retired terrace in the front of his residence, beyond which lay the Bay of Macao, encircled by hills. The cerrace was shaded by beautiful flowering shrubs, and bordered with Western plants and flowers." Here, accompanied by the whole of his family and attendants, a favourite Newfoundland dog being always present, most happy hours of converse were spent. Often after a Sabbath's labours, involving five or six hours' standing and speaking, has he sat thus conversing on the blessings and mercies of life. And if sometimes asked whether he was not tired, his reply would be, "Yes, tired in the work, but not of it. I delight in the work."

Symptoms began to appear that his constitution, so strong and wiry, was beginning to fail. A sensation of weight in the top of his head, sleeplessness, loss of appetite, pain in the right side, and great prostration of strength, caused him and his partner serious apprehension. $\mathrm{He}$-consulted a doctor, who appeased his fears by stating it was an affection of the liver, and that it was only an apparent and not a real loss of strength, and that when the excitement caused by the departure of his family to England was past he would be quite restored. With these assurances he returned to Canton, in order to conduct a correspondence having reference to an affray on board one of the opium ships, in which a Chinese had been killed. Here he remained until within a fortnight of his family leaving Macao. Then the Select Committee accepted the services of his eldest son, and he returned to his family. Arrangements were made for them to sail on December Ioth, I833, and they were to embark at Lintin, a safe anchorage eighteen miles from Macao. On that day, therefore, he and his family, save Mr. J. R. Morrison, who was to remain at Canton, sailed in a small passage-boat to Lintin, and arrived after a painful passage, 
the whole company being cold, sick, and dejected. The party was taken on board the ship Inglis, prayers were offered, farewells were taken, and the family separated, never again to meet in this world.

In the uncertainty of his future prospects, Dr. Morrison at once gave up his home at Macao, and returned to Canton.

The exchange of the East India Company's régime in China for an administration by the Government of England gave rise to much and prolonged difficulty between the Chinese and the English Parliament. A Bill was ultimately passed giving the Government power to do much as it pleased in carrying out a system of commercial interchange, customs, etc., and Lord Napier was appointed the Chief Ambassador of the English Court to China. Several members of the East India Council strongly urged upon him and his suite to secure the valuable services of Dr. Morrison as translator and secretary to the Embassy. But a ter all the worse than coolness which had been manifested by the English Government towards Missions, it seemed most unlikely that a missionary should be employed by it for the transaction of business so inportant and delicate as must attach to the vacant office. No certainty could be attained until the arrival of Lord Napier and his attendants.

On May 1st, 1834 , Dr. Morrison wrote this entry in his journal: "On the 28 th of this month it is thirty years since I was accepted as a missionary in Mr. Hardcastle's countinghouse, at the end of the old London Bridge. Rowland Hill was there, and asked me if I looked upon the heathen as angels did. As I did not know the mind of angels, of course I could not say 'Yes." "

On July 15th he wrote from Macao: "Lord Napier landed yesterday about $3 \mathrm{p} . \mathrm{m}$. The frigate fired a salute when he left the ship, and the Portuguese fired one when he reached the shore. I went down to the Chinese custom- 
house, where he landed, and handed one of his daughters from the boat to my chair, in which she went up to D.'s. I introduced myself to him in going upstairs. He took me by the hand, and said he was glad to make my acquaintance. He was dressed in naval uniform. Lady Napier rose from her chair and walked towards me to shake hands, with a smiling countenance and civil speech, saying she seemed to have been long acquainted with me, being so familiar with my name.

"At noon to-day a meeting of all the Factory people was summoned at Lord Napier's to hear the King's commission read. That which concerns you* and our beloved children I will tell first. I am to be styled 'Chinese Secretary and Interpreter,' and to have thirteen hundred pounds a year, without any allowances whatever for domine, house-rent, or anything else. I am to wear a vice-consul's coat with King's buttons, when I can get one. Government will pay one hundred dollars a month to the College, instead of the Company. His lordship asked whether I accepted of the appointment or not. I told him at once that I did. He then said he would forthwith make out my commission. . . . Pray for me that I may be faithful to my blessed Saviour in the new place I have to occupy. It is rather an anomalous one for a missionary. A vice-consul's uniform instead of the preaching gown!"

- In writing to his little boy, Robert, he says, concerning this same subject: "You must know that dada is a king's servant: King William is my master. However, Robert, my dear boy, I have a greater master than England's king. The Lord Jesus Christ is $\mathrm{He}$ whom I serve. . He has gone to prepare a home for me and for you and all who serve Him in His Father's house in heaven." This was the last letter he ever signed.

On July zoth Lady Napier wished him to preach in the

* Addressed to his wife. 
Company's chapel at Macao, and he prepared to preach a sermon he had just composed from the words, "In My lather's house are many mansions" (John xiv. 2); but an objection was raised by some narrow-minded sectarian, and no service at all was considered better than one conducted by a minister who was not properly ordained.

This sermon shows clearly how much his mind seems to have been led to dwell upon the unseen world of glory, as though anticipatory of an early decease. It suggests four topics of consolation to the Christian under circumstances of affliction. First, faitl in God as their reconciled Futher, and in Jesus as the promised Messiah, the great Redeemer who came to save His people from their sins; second, the recollection that they had been adopted into the family of God; third, that they had a rich inheritance; and, fourthly, that they were advancing towards an cverlasting home, the happiness of which would consist in a great degree in the society formed there, the family of God, from all ages and out of all nations-patriarchs, prophets, apostles, martyrs, and confessors, with the more humble followers of the Lamb, and, above all, the Saviour, whom they would see face to face. In describing the heavenly state the writer rose to an unusual vividness and impressiveness of style.

On the 23 rd he accompanied Lord Napier to Canton, his presence being necessary in any interview between the ambassador and the Chinese Government officials. He suffered frightfully on the voyage. He quitted the frigate at the Bogue, and remained all night in an open boat, exposed to the extreme heat and a storm of rain. He was, therefore, utterly spent when he landed, and had the prospect of exciting and anxious negotiations before him.

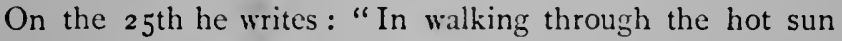
to-day from this house to the Company's, where Lord Napier is, I was like to drop in the streets, and have been groaning on my couch ever since, being now past eight in 
the evening." The next day he attended the Council from ten to three, occupied in the work of translating letters. On Sunday, the 27 th, he conducted service with the Chinese, having, perhaps, the largest congregation he had been privileged to see, and he was cheered by old Le, who had long transcribed for him, telling him that he had been led to belicve in Christ Jesus. The day before his name had been published with those of the officers of the King's Commission, being placed above those of the surgeons, chaplains, and private secretary. On the following day he dragged himself to his official duties, and had a wearisome time, with the squabbles between the native and English officers, and then his earthly labours were over. He spent a wretched night on the Tuesday, and on Wednesday a surgeon was sent for. Everything that doctors or his son or attendants could do was attempted, but a fever raged within him that apparently nothing could assuage. Leave of absence from Canton was given him, but he was too feeble to be removed. On Friday evening the doctors in attendance tried other means for his relief; but he was rapidly sinking, and at about ten o'clock in the evening he closed his eyes and slept. It was the sleep of the righteous, from which he awoke in glory. He passed thus quietly into the mansion in the Father's house prepared for him by the Saviour, and concerning which, as if prophetically, he had prepared his last discourse.

The sorrowful tidings were conveyed by letter to his partner in words full of tenderness and consolation from his eldest son: "On Friday, July $25^{\text {th }}$ I had the happiness again to see my father after a separation of neaily five months. But that pleasure was greatly damped by the extreme weakness which prostrated all his bodily powers, but which never touched his powerful mind. On the 27 th, which was Sunday, he had his little Chinese congregation around him, and addressed them as much as his strength would permit, and truly it was in this heathen land a most 


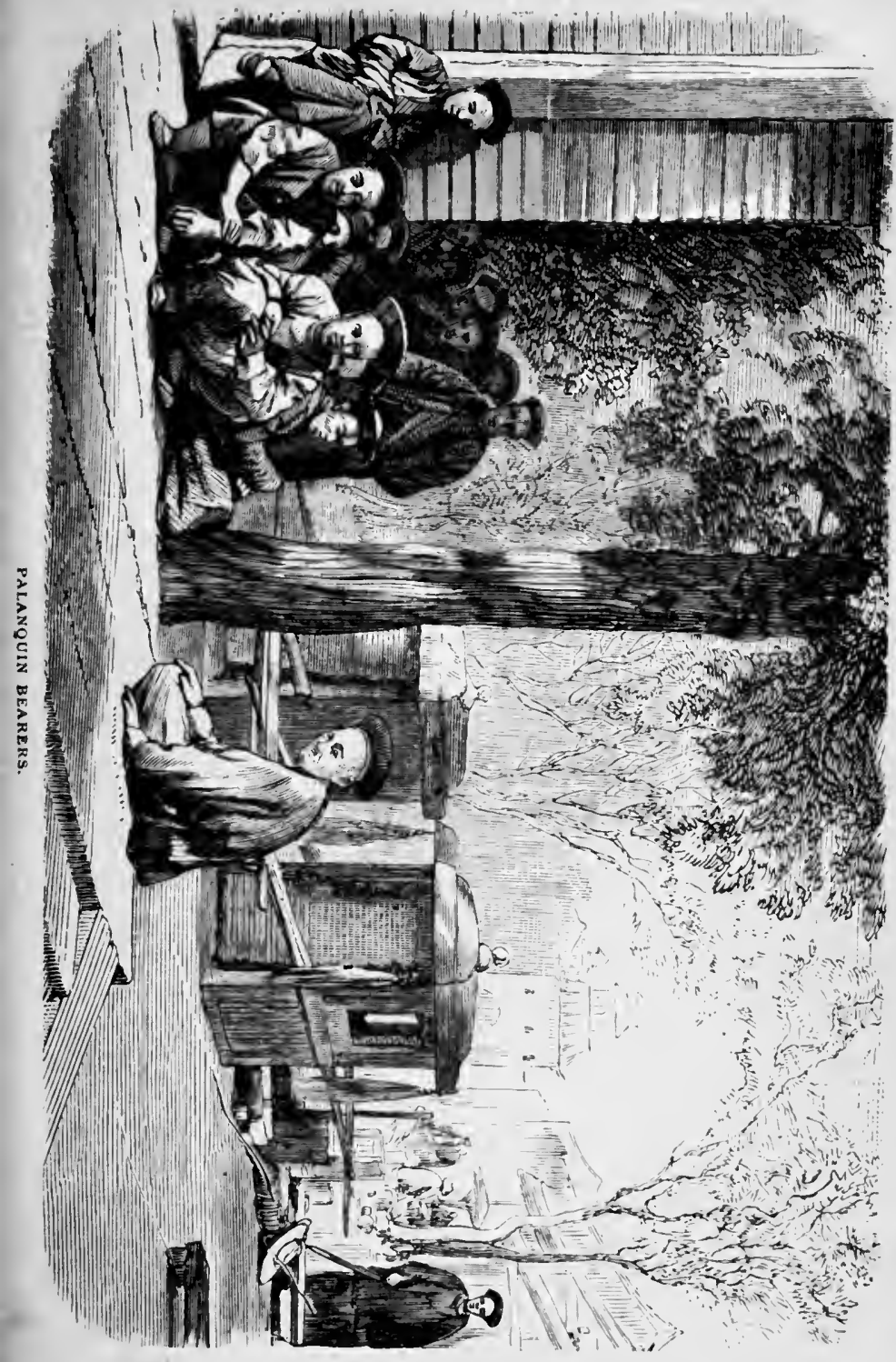


cheering sight to see upwards of a dozen Chinese of the most depraved city of this debased empire joining in prayer and praise to our crucified Redeemer. A greater than usual degree of solemnity appeared to pervade the little congregation as we received from those lips, then dying, though we knew it not, the words of everlasting life. And loudly did we sing praises to the Lamb who was dead, and is alive again, and who liveth for evermore.

"On Monday and Tuesday his weakness and pain slowly increased: On Monday he went twice in a palanquin to Lord Napier's. The next day the chairmen were afraid to come, but had they come he could not have gone out."

Mr. J. R. Morrison describes fully the medical treatment of his father up to Friday evening, and then continues: "Our beloved sufferer had received ease the night before from the use of an opiate, and requested the same mode of relief. But the fever of his frame was such that they dare not give it him without first taking from him some. blood. He submitted, not without reluctance. -They bled him; but, alas! it was too late. After the arm had been tied up and the bleeding stopped, he began rapidly to sink, and refused the opiate. All pain appeared now to have left him. He was still able, however, to move from his bed, and was with difficulty kept quiet. I had gone out to obtain speedily some medicine. When I returned his cheek was pale and his eye glistened. His feet were cold. By artificial means we endeavoured to restore circulation of the blood. All our efforts were, alas! in vain. $\mathrm{He}$ ceased to speak or to struggle for about twenty minutes, and about ten o'clock he closed his eyes and slept. The next moment we cannot doubt his liberated spirit was before his God, clothed in the robes of Christ's righteousness, and arrayed in the garments of salvation.

"On Saturday evening I embarked with the precious 
remains to convey them to Macao, and deposit them beside the grave of her who gave me birth."

$H$ is remains were attended from the house to the place of embarkation by Lord Napier, and all the Europeans,

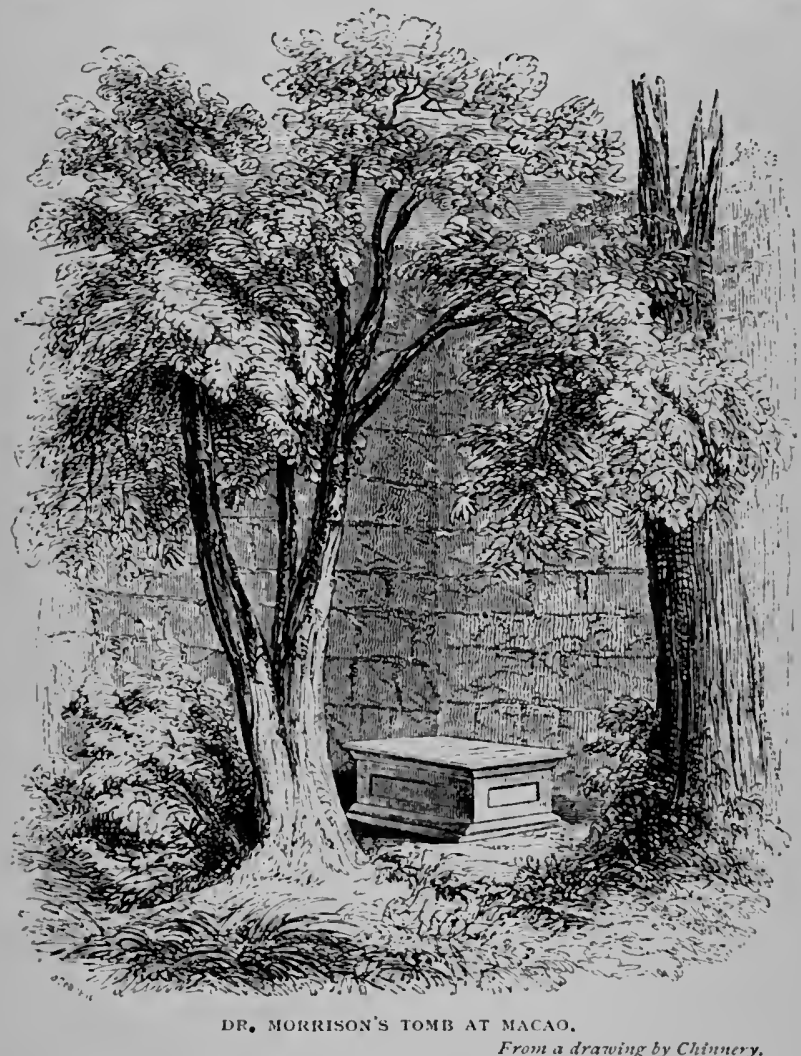

Americans, and Asiatic British subjects then in Canton. Sir George Robinson and other honourable gentlemen accompanied them to Macao, and the service was read by the Rev. E. Stevens, Seamen's Chaplain at Canton. 
The following inscription was placed upon his tomb:-

Sacred to the memory of

ROBERT MORRISON, D.D.,

THE FIRST PROTESTANT MISSIONARY

TO CHINA,

where after a service of twenty-seven years cheerfully spent in extending the kingdom of the blessed REDEEMER, during which period he compiled and published

a Dictionary of THE CHINese language, founded the Anglo-Chinese College at Malacca, and for several years laboured alone on a Chinese version of

THE HOLY SCRIPTURES,

which he was spared to see completed and widely circulated antong those for whom it was destined, he sweetly siept in Jesus.

He acas born at Morpeth, in Northumberland, January $5^{\text {th }}, 1782$, was sent to China by the London Missionary Society in 1807 , was for ta'enty-five years Chinese translator in the employ of The East India Company, and died at Canton, August Ist, 1834 .

"Blessed are the dead which die "n the Lord from henceforth: Yea, saith the Sptrit, that they may rest from their labours; and their works do follow them "

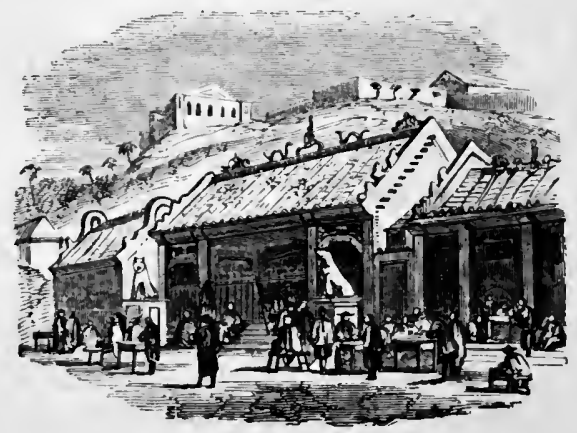




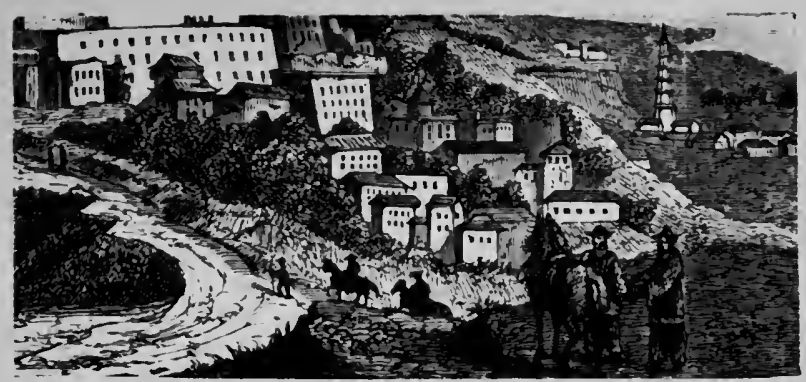

\section{CHAPTER NIV.}

\section{WHAT HE IVAS AND IVIIAT HE DID.}

" Who sow good seed with tears shall reap in joy."

So thought I as I watched the gracious rain,

And decmed it like that silent sad cmploy

Whence sprung thy glory's harvest, to remain

For ever. God hath sworn to lift on high

Who sinks himself by true humility."-KEBLE.

THE intelligence that so great and good a man had passed away from this life produced a profound sensation, not only in China and in England, but in every part of Christendom. 'The religious societies of England, America, and even of the continent of Europe, were prompt to express the lofty esteem in which they held his character and the work he had sought to perform. The London Missionary Society appointed a pullic service commemorating his long devotion to the Mission cause, at which a sermon was preached by the Rev. Dr. Fletcher, of Stepney, to an overflowing and much impressed audience. The personal friends of Dr. Morrison in China, very numerous and influential, promptly resolved to estallish a memorial institution by which a portion of his work could be permanently conserved, and the public esteem in which he was held could be suitably expressed. A liberal subscrip- 
tion was opened, by which about two thousand pounds were collected, and in 1835 "The Morrison Education Society "was established and put into operation.

His life was an unbroken course of self-sacrificing effort for the attainment of the great end he had set before him at the beginning of his student course-the salvation of the heathen. His attainments in philology were all consecrated to this ; the civil and official duties he discharged through so many years were only undertaken and fulfilled for the sake of the opportunity afforded of maintaining a standing in the country, and of being permitted to pursue his higher work unmolested, and yet they were discharged so efficiently as to merit and receive the most flattering and grateful acknowledgments of the wealthy and influential Company that employed him. The large salary he for a time received enabled him to live without drawing on the funds of the Missionary Society for his personal support, and to give with even princely liberality, considering his means, to promote the work of education and religion in the East.

$\mathrm{By}$ the learned and distinguished personages with whom he came in contact he was treated as an equal, because his own extensive attainments in learning, and his natural dignity, diminished all sense of distance which might otherwise have been felt on account of their different social positions; and by his Chinese, Portuguese, and English dependants he was revered as a friend whom they could approach without fear, and confide in with assurance. The work he accomplished will ever remain as a monument of indefatigable and patient industry. The translation of the Scriptures, carried out mainly by his own agency, has long since been surpassed by others, more perfect in their renderings, and more idiomatic in style, but this does not detract from the praise due to his untiring labour in having laid a foundation on which others have nobly built. The Anglo.Chinese Dictionary was a miracle of plodding and sagacious diligence, prolonged through many years, and for 
its proportions and encyclopxdic character stands perhaps unrivalled in human literature as the work of one man. The catalogue of his other works cannot be enumerated; but books of doctrine, history, education, catechisms, prayers, hymns, etc., flowed from his unceasing pen until the list is contemplated with amazement. Dr. Medhurst, in "China: Its State and Prospects," 'says that no fewer than $751,76_{3}$ copies of tracts and books were poured forth from the Chinese Mission presses from 1810 to 1836 . A very large proportion of these came from the pen of Dr. Morrison, and indeed Dr. Medhurst declares that his list making up that number was by no means complete.

To his literary labours must be added also the time and effort consumed in establishing and aiding to carry on the various benevolent and religious institutions which owed their origin to his energy and zeal. The Anglo-Chinese College at Malacca occupied much of his thought, and to its welfare he devoted time and money ungrudgingly. It accomplished much good, although it came far short of the idea of its founder. 'That it did not accomplish more, and that the Singapore Institution and the Language Institution failed, was in no sense due to Dr. Morrison, but rather to the unfaithfulness of agents in the one case, and the slowness of the Christian sense of England to appreciate the possible benefits to be derived from the other.

His character presents many features and qualities which must command fervent admiration. He had an ardent thirst for knowledge; he cultivated a fine sensitiveness of nature as to moral uprightness; he manifested unswerving conscientiousness; he had an inexhaustible genius for patient, perscvering, plodeling industry; and, as an internal fire, there ever glowed within him the steady flame of love for Christ and zeal for His glory, which lighted with lambent glow all the qualities of heart and mind which made up a noble personality. He was precisely fitted to the position he was called to fulfil. His caution, his 
common sense, his soundness of judgment, never failed him, and the result was that he never had to take a backward step. If he baptised but few converts, he had great reason to rejoice that those who were received into the Church by baptism gave him no cause to mourn over their defection or apostasy; and if he gathered no crowds to hear him preach the Gospel, it must be remembered that his conditions and circumstances forbade him exercising such public ministrations, and forced him to adopt the only other way open to him of reaching the Chinese intellect by appeals through the press. His patience was severely tried, but his faith in the ultimate success of the work never faltered; he was often exposed to persecution, and his life was threatened by imperial edict, but his cheek never paled nor his heart palpitated with apprehension. He did all that he could, and what few men could have done, and he lives to-day in the deep and growing interest in the Chinese Empire, and in the intense enthusiasm which is being manifested for its conversion. The influence of such a life and character can never die, but must extend and diffuse itself in ever-widening fragrance and blessedness wherever his name is known or his deeds are recorded.

On the death of Dr. Morrison, his son, although only nineteen years of age, was appointed his successor as Chinese Secretary and Interpreter to the British Embassy. Such was his maturity of character, general knowledge, vigour of intellect, and high attainments in the Chinese language, and such his knowledge of forms, usages, and principles of the Chinese Government, that his services won the highest appreciation from the British Government. $\mathrm{He}$ was employed by Sir Henry Pottinger as chief interpreter in all his negotiations with the Chinese authorities during the whole of the war, and was the chief agent in arranging with the Chinese the treaties which formed the basis of a settlement between the two countries. He was prudent 
in counsel, conciliatory in style, jealous of the honour of England, but fair to the Chinese, and he gave himself with unflagging zeal to his delicate and onerous duties until peace was established between his own and the foreign government.

$\mathrm{He}$ was a devoted Christian, the adviser and protector of the native converts when they were exposed to persecution and injustice, the companion and benefactor of the missionaries who were sent into the Empire or the contiguous settlements, and the enlightened advocate of every effort which tended to advance the intellectual or moral welfare of the East. His public duties, however arduous, were discharged so as to draw out the confidence and admiration of those who employed him, and he was so unremitting in his attention to them that his health failed. He received leave of absence for a time, that he might seek its restoration; but pressing duties led him to delay his holiday, until he was seized with a fever, which was at the time an epidemic, and of which he died at Macao on August 29 th, 1843. He was buried in the cemetery by the side of his father and mother.

Besides being Interpreter and Chinese Secretary, he had been elected a member of the Legislative Council at HongKong, and appointed the Colonial Secretary. In announcing his death, His Majesty's plenipotentiary, Sir Henry Pottinger, expressed his conviction that it was a national calamity, and said that no man living could supply his place. Sir Robert Pecl, Bart., speaking in the House of Commons in reference to both the father and the son, declared that in the whole range of public service two men could not be found more remarkable for their high character and fidelity.

Dr. Morrison's eldest daughter married Dr. Hobson, a scholarly medical missionary in Canton, who left an enduring record in eighteen medical works, most of them illustrated, and still survives, a worthy descendant of her honoured and famous father. 


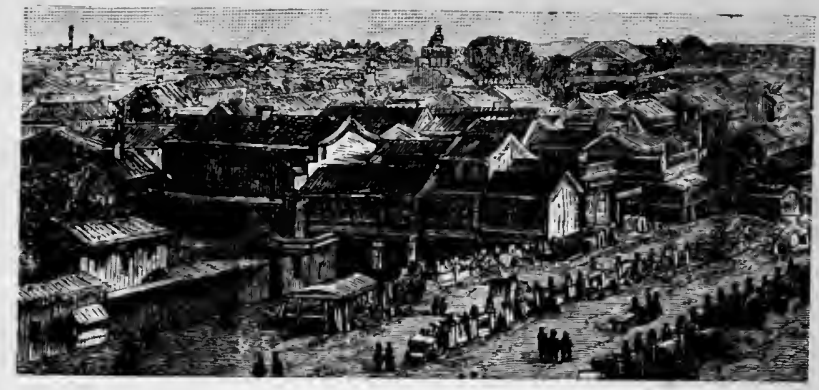

CHAP'IER XV.

THE LONDON MISSIONARY SOCIETY.

"Through midnight gloom from Macedon, The cry of myriads as of one ;

The awful silence of despair Is eloquent in awful prayer; The soul's exceeding bitter cry,

'Come o'er and help us or we die!'”

THE London Missionary Society having once boldly attempted to enter China and make known the Gospel, sent out in rapid succession a number of men who laboured faithfully to lay the foundations of a widely extended Christian Church amongst the Chinesespeaking peoples of the East. Following Dr. Milne, who was sent out in I8I3, there came the Rev. W. H. Medhurst in 1817 , who labcured first at Malacca, and then amongst the Chinese in Batavia, on the island of Java. Upon the opening of the five treaty ports in 1842 , he removed to Shanghai. He was long the senior missionary in the field, and obtained a very familiar acquaintance with the Chinese language. He had a fine presence and dignified manner. His command of language made him an impressive speaker both in Chinese and English. He laboured much to 
diffuse a knowledge of Christ by the voice, but even more still by the pen. In 1835 he published an English and Chinese dictionary containing fifteen hundred octavo pages, and which is well adapted for use by the general student. Afterwards he prepared vocabularies for Corea, Japan, and China. He prepared a version of the New Testament, and several valuable tracts on the Christian religion. When on a visit to England in $18{ }_{3} 6$, he published a most interesting volume, called "China : Its State and Prospects," which had a large sale, and did much to deepen the concern of the churches for the welfare of that land. He returned to his work, and sedulously pursued it till $185_{5} 6$, when he again returned to his native land to plead the cause of China. He was suddenly cut short in his career soon after reaching his native shores. He died January 24 th, 1857 , aged sixty years, leaving a reputation unblemished for its piety, and fragrant with works of love and mercy.

Several others laboured at Penang, Malacca, and Singapore, chiefly amongst the Chinese settlers, who soon returned to England through failure of health or other causes, and who need not be further particularised. Rev. David Collie was a man of much promise, who was sent to Malacca in 1822 . He succeeded Dr. Milne as principal of the Anglo-Chinese College, and translated the Four Books of Confucius. He mastered the language in an unusually short time, and laboured with great energy and success till is $\$ 28$. Then his health failed, and he started upon a homeward voyage, during which he was removed to the rest of heaven.

Rev. Samuel Dyer was another worthy agent of the London Missionary Society, who was born at Greenwich in 1804 , and in 1827 arrived at Penang. While Dr. Morrison was in England he and Mr. Dyer had much intercourse, and chiefly under his instructions he was able to read imperfectly the Bible in Chinese before starting on his voyage. He performed really splendid service in translating, preaching, type-making, and teaching the young: 


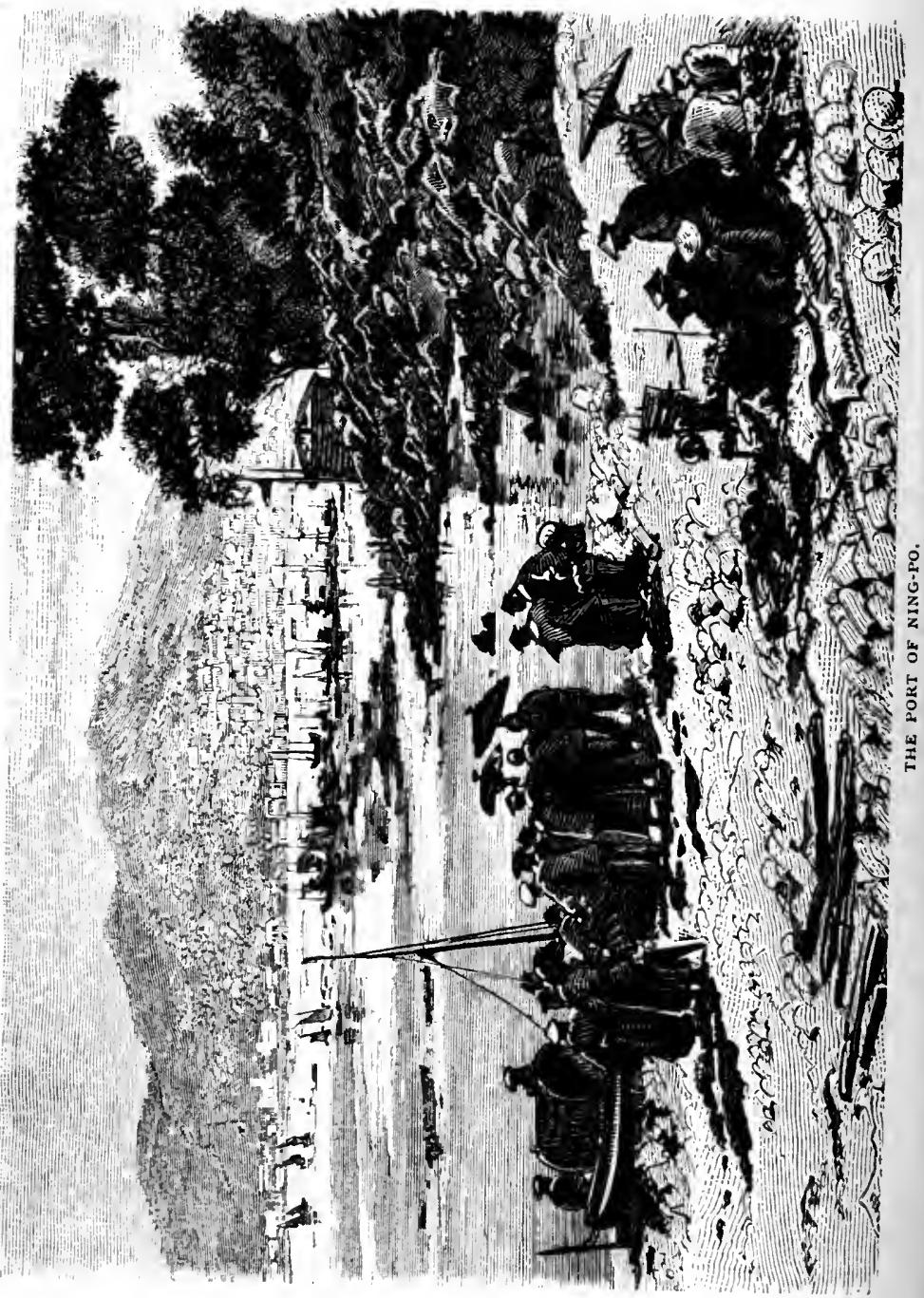


shedding a blessed influence around him everywhere till 1843 , when the end came. He had gone to a convention of missionaries at Hong-Kong, called to confer as to the more perfect translation of the Holy Scriptures. He was appointed the secretary of the meeting, which involved much labour and anxiety. The object of the meeting was to unite the various evangelical agents in China in the use of one version of the Bible. The good men could not be drawn into accord, especially as to the term which was to be used for God ; and so, after several days' discussion, the meeting ended without any conclusion being reached. He proceeded to Canton, where he suffered a severe attack of fever, but recovered so far as to sail for Singapore. But as the ship called at Macao he had a severe relapse, was taken ashore, where he soon peacefully slept, nevermore to wake till the trumpet shall sound. His last words were, "Blessed Jesus! Sweet Saviour! I go to be with Him who died for me." He was buried by the side of Dr. Morrison, and the two who had been united pleasantly in life found a resting-place together.

Agents of the London Missionary Society assiduously sought to lay the foundations of the Christian religion amongst the Chinese in the Straits Settlements ; but when at the close of the opium war of 1842 , the five ports-Canton, Shanghai, Amoy, Foo-chow, and Ning-po-were opened to foreigners, and the island of Hong-Kong became a British possession, they were removed to China, and in sone of these cities there were soon to be found churches, schools, and large printing establishments. The Anglo-Chinese College founded by Morrison was removed to Hong. Kong, and was for years under the excellent management of Rev. Dr. Legge. In that seminary great numbers have been taught English and Chinese, have been carefully instructed in religion, and many have given evidence of real piety. Some have become Christian agents, others have gone out as interpreters in merchants' offices and govern- 
ment departments, where they have been able to exercise a widespread and useful influence.

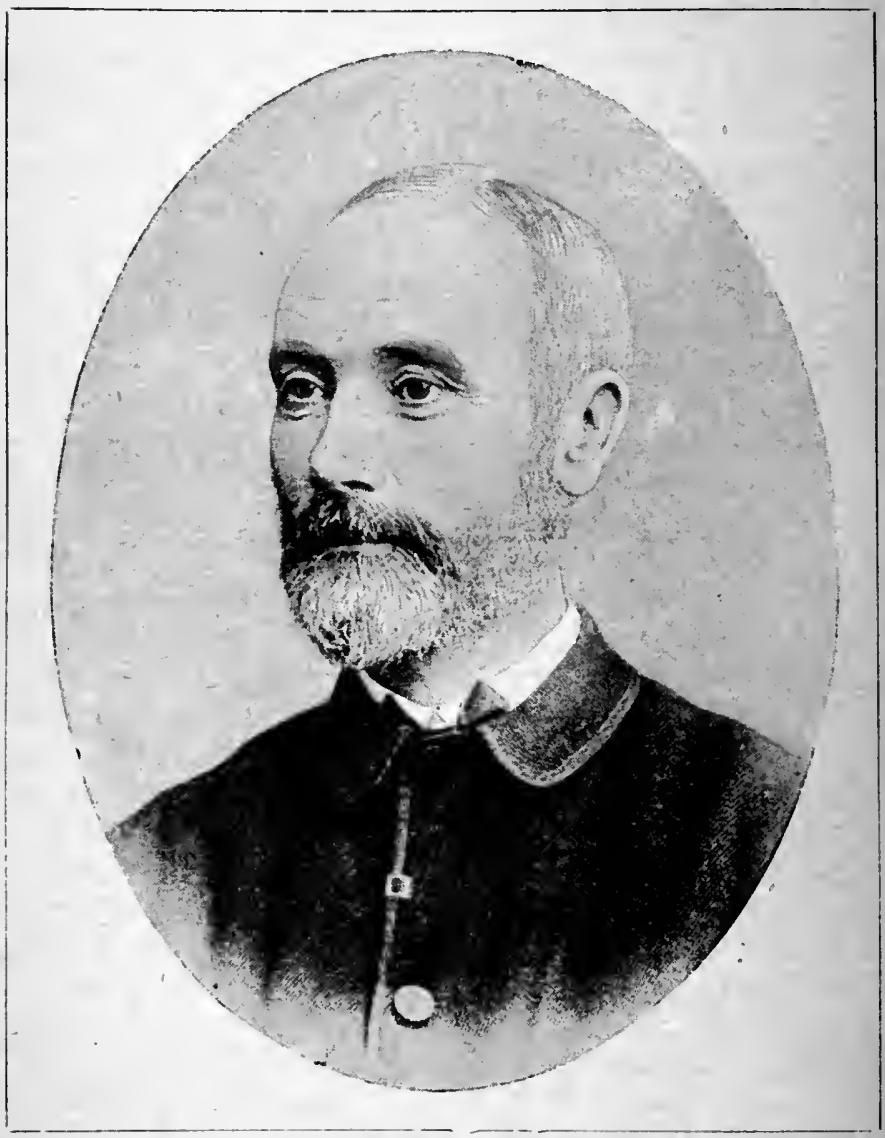

REV. JAMES GILMOUR, M.A.

In 1839 the London Missionary Society sent out its first medical missionary, Dr. W. Lockhart, who first laboured at 
Macao, and then removed to Shanghai. He was accompanied or followed by Rev. James Legge, Rev. W. C. Milne (a son of Dr. Milne), and Dr. Hobson, afterwards son-in-law of Dr. Morrison. These again have been succeeded by many others who have written their names indelibly in the history of the evangelisation of the Chinese Empire. Amongst these may be named Rev. IV. Muirhead, Rev. J. Edkins, D.D., Rev. J. Chalmers, D.D., Rev. Griffith John, D.D., and others, who have done earnest and successful work in Hong-Kong, Canton, Hankow, Shanghai, Tientsin, and other places.

This Society has now extensive missions and valuable establishments in five provinces, and still maintains a position that befits the pioneer Society in the work of piercing with Divine light the densest and largest heathen empire in the world. 'The principal centres occupied by the agents of the Society are as follows:-

Pekin, where there are not only preaching centres, but medical hospital and girls' training schools, with a staff of eight European missionaries, supplemented by many pious native helpers. The Rev. G. Owen is the senior missionary in the field. It is with decpest regret that we observe that the Rev. J. Gilmour has recently dicd. He was a man of great force of character, of somcwhat original methods, adapting himself freely to the habits of the natives, that he might better win their confidence if possible, and counting no sacrifice too great to be made if he could thereby promote the great work. He gave himself up enthusiastically to work in Mongolia, and came to be called affectionately by the natives amongst whom he lived "our Gilmour." There was cverything about him to attract the affections of the people. He devoted himself to the welfare of the Mongols in every respect. As a doctor he prescribed for their ailments; he denied himself home comforts, that he might travel from place to place the more readily; he was a vegetarian, that he might have the more to spend upon his work; and in a brilliant review of his fascinating book, "Among the 


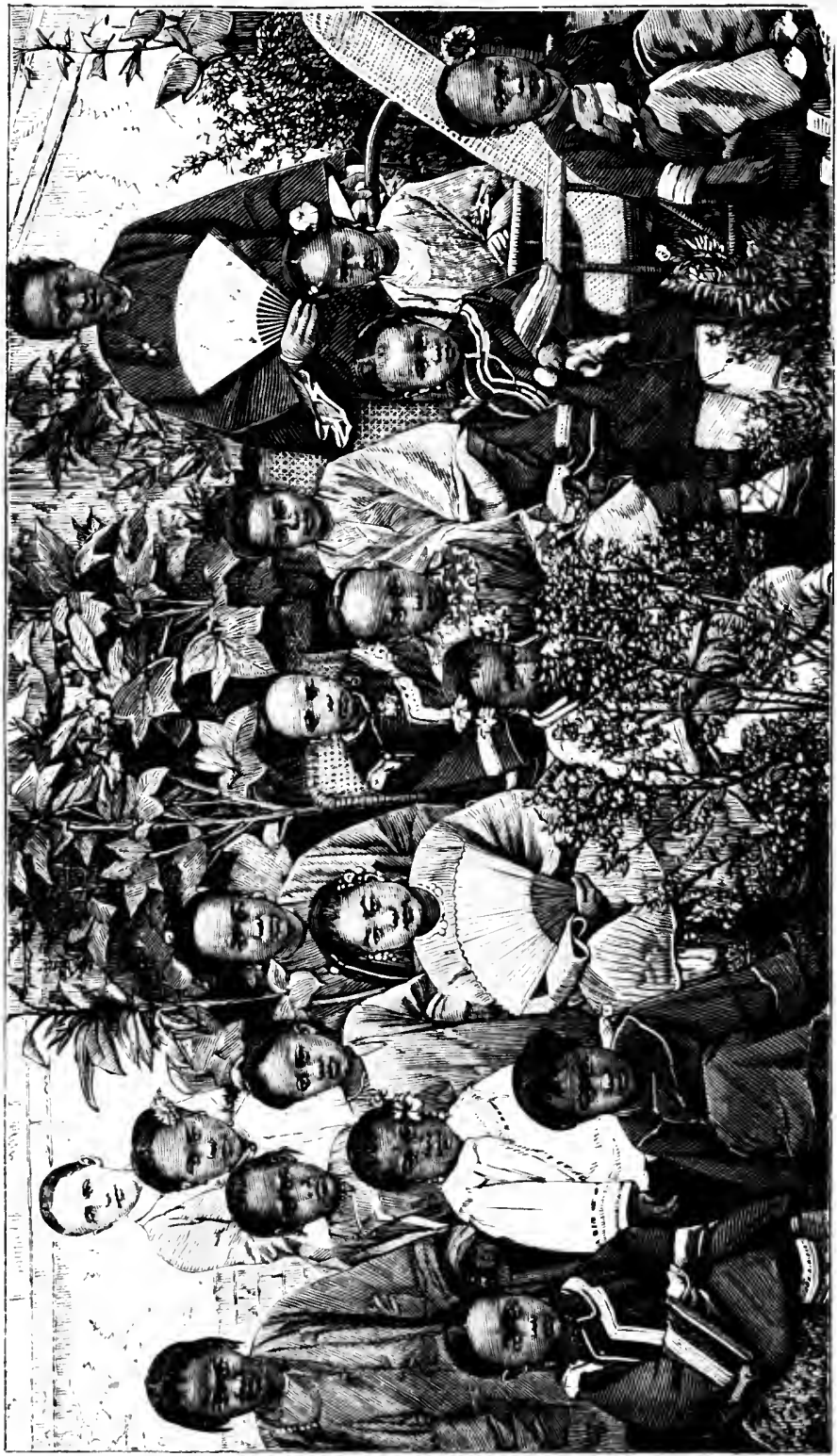


Mongols," which appeared in the Spectator, it is said, "As for danger, he had made up his mind not to carry arms, not to be angry with a heathen happen what might, and, although he does not mention this, not to be afraid of anything whatever - neither dogs, nor thieves, nor hunger, nor the climate; and he kept these resolutions. It has been justly said by a friend, 'He has been called away perhaps to higher service, because no one can imagine such a restless, untiring spirit as his doing nothing.' "

The girls' training school in the capital city is a fine institution and under skilful management, and doing much to train Christian women, who may hereafter become Bible readers to their own sex, or will make pious and helpful wives to the native agents and members in the Mission.

Tientsin.-In this great seaport the London Missionary Society commenced its work in $\mathbf{r} 86 \mathrm{r}$. There is scarcely a finer sphere for the Christian agent in China than here. Tientsin is not only the location of an immense population, but it is the centre of a wide district, the inhabitants of which come crowding into it from all quarters both by sea and land. It is, moreover, the principal centre of the railway and telegraph systems in China, and is more deeply touched by the modes of western civilisation than any other place. It is no wonder, therefore, that it is the headquarters of several missionary societies. Rev. Jonathan Lees is the senior agent, having laboured here since the commencement of the Mission in $186 \mathrm{r}$. He is well sustained by several other clerical missionaries, and also by two medical and two lady agents. A very beautiful medical hospital was built here some years ago, chiefly through the liberality of the great commissioner, $\mathrm{Li}$ Hung Chang, Viceroy of the Imperial Province. Lady $\mathrm{Li}$ had been greatly benefited by the instrumentality of Dr. Mackenzie and Miss Dr. Howard, now Mrs. Dr. King, and in gratitude they erected the hospital, which for many years was under the management of the London Society. Through the interference 
of the Chinese officials some alteration has been made in the management but not in the usefulness of the institution.

A very interesting feature in the work at Tientsin, is the girls' school under the management of Mrs. Bryson, wife of Rev. T. Bryson, who has been on the Mission for twenty-five years. In the year 1885 , Mrs. Bryson commenced a class for women on Thursday afternoons. A large number attended at first, no doubt prompted by curiosity. But gradually the number decreased until only a handful remained, who, however, showed deep seriousness, and learned to engage in prayer with much earnestness. In a few months a girls' school was attempted, and a wellqualified native female, who had been trained by Mrs. Edkins at Pekin, was engaged as teacher. Fifteen girls were soon under careful tuition, most of whom have given satisfactory evidence of conversion and proficiency in Christian knowledge. Already this school has borne fruit in providing pious wives for native helpers and useful workers in the Mission in several departments. Too much importance cannot be attached to such an agency in a heathen land like China, where the education of women is utterly neglected, and where social customs forbid women entering public assemblies where the Gospel is preached.

Hankow.-The life and soul of the Mission in Hankow has been Rev. Dr. Griffith John. He went out to China in 1855 , and is now a well-worn but still a stalwart veteran in the field. He was aided in the commencement of his work by the Rev. R. Wilson, B.A., who died in 1863 , and is buried in the cemetery. There is a chapel in the centre of the city where daily preaching of the Word is carried on for four or five hours without intermission to ever-varying crowds of people by the missionaries and native helpers. Near to the English settlement is the hospital and boys' school, with teacher's house, and in another part of the mission compound is a school for girls with house for the 


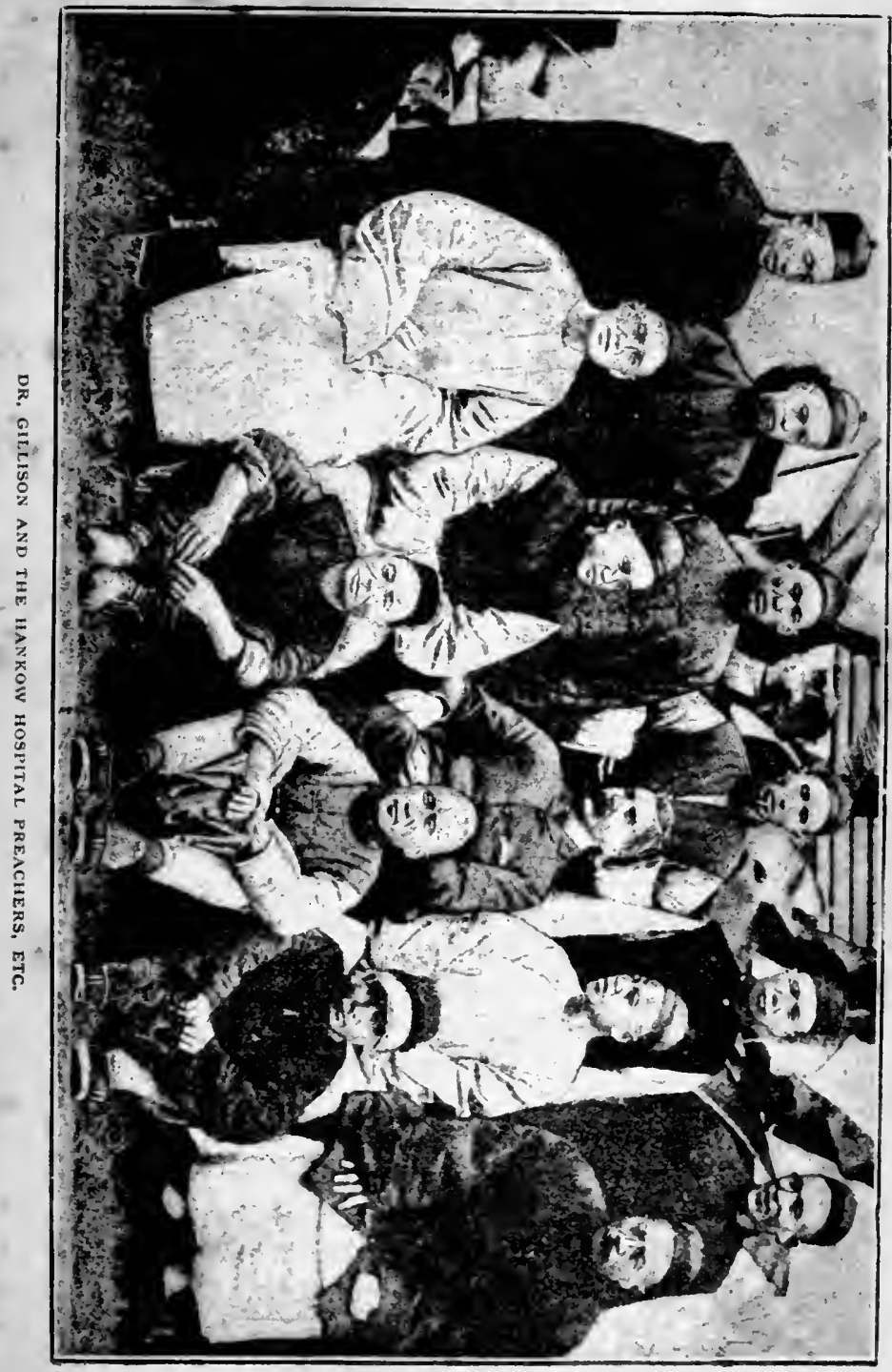


teacher. This is a very complete mission establishment, and is doing a great work. There are several country stations, and also a mission at Wuchang where two English ministers reside. The commercial importance of Hankow makes this mission a very promising and influential one. The hospital, which is under the care of Dr. T. Gillison, accommodates about seventy patients; and in addition to this, a new hospital for women has recently heen erected chiefly at the expense of Dr. John, in memory of his devoted wife, Mrs. Margaret John.

AMoy.-In this important seaport, the two brothers, Revs. John and Alexander Stronach, established a mission when the treaty of $\mathrm{I}_{42}$ opened it to foreign residents. They had previously laboured at Singapore. They were followed by Drs. Hirschberg and Hislop in 1847 and 1848 , and slowly a substantial work arose round them. The senior agent now there is Rev. J. Macgowan, who began his labours in 1859 , and next to him is Rev. J. Sadler, who went in $\mathrm{r} 866$. Two lady missionaries are engaged on the Mission, and in addition to the ordinary agencies employed, a gospel boat has been built that the missionaries may visit places round the neighbouring coast, where preaching stations have been established. The boat is an excellent one, and built with special reference to the needs of the Mission.

Shanghar.-The veteran missionary of China, Rev. W. Muirhead, has long been in charge here, and is looked up to by the agents of all the societies in China with respect and confidence. He superintends the general work, and has two lady helpers who are accomplishing much good for the girls of the city, in the management of an excellent Christian school for their benefit. This is fitting, indeed, in the city where the celebrated well exists in which female babies have been for generations abandoned to die by starvation.

HonG-Kong.-On the cession of this island to England 


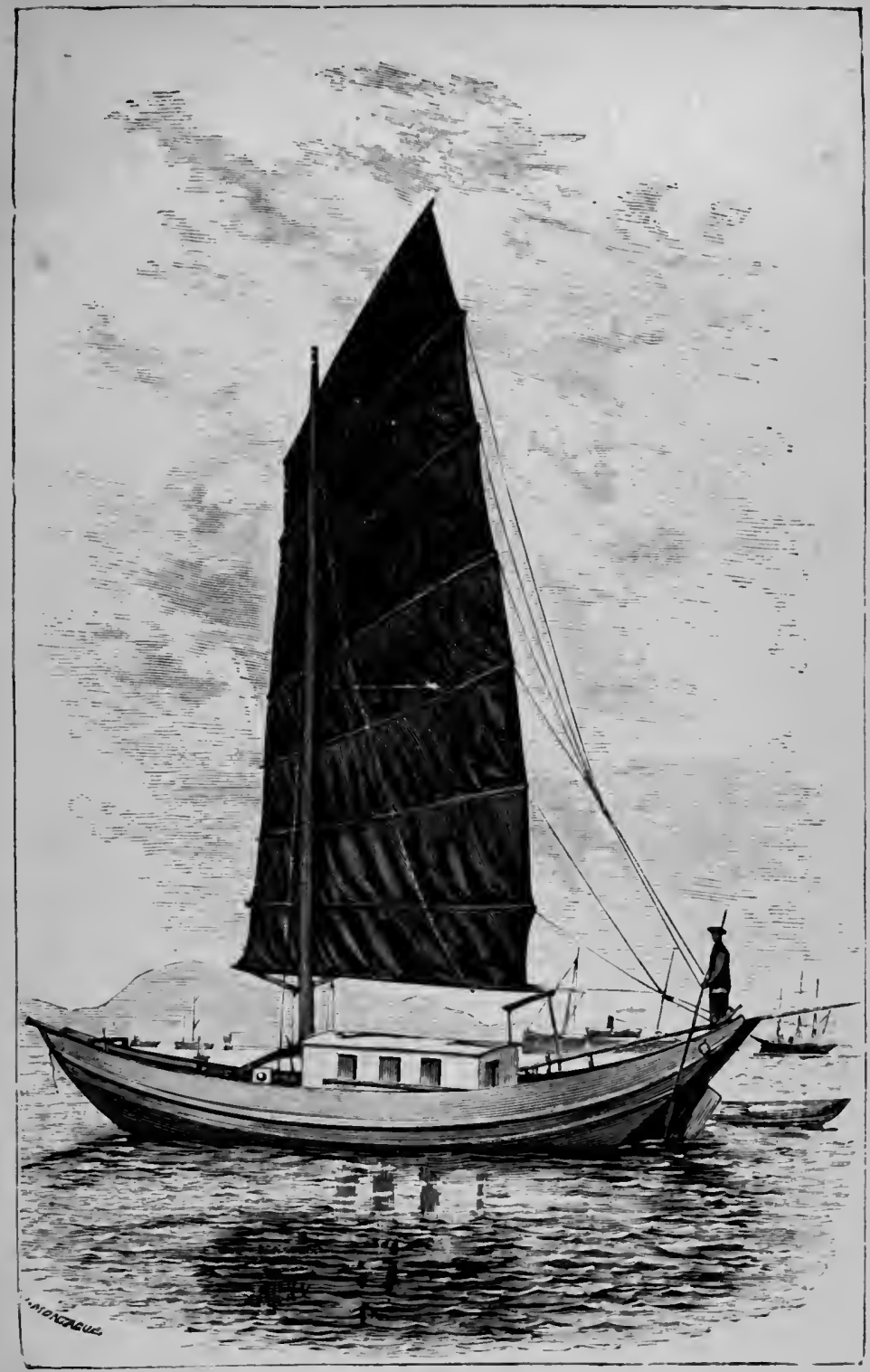


in 1842 , Rev. J. Legge, afterwards Dr. Legge, went thither and actively carried on mission work of various kinds. He was an able and accomplished man, whose fame became a universal possession, and who by his literary labours did much for Christianity in China. On the transference from Malacca to Hong-Kong of the Anglo-Chinese College, he found a congenial sphere as the principal thereof, and he was afterwards joined by Revs. W. Gillespie, J. F. Cleland, and $\mathrm{J}$. Chalmers, with the medical agents Drs. Hirschberg and Hobson. The hospital carried on by these healers of the body was of signal service to the general work of the mission. A few years since the Alice Memorial Hospital was established, and is now very ably and successfully superintended by Dr. Thomson. The senior missionary is Rev. J. Chalmers, D.D., and he is assisted by Rev. G. H. Bondfield and Miss Rowe.

Canton.-In this original centre of mission operations in China, all vestige of the work done by Dr. Morrison seems to have been lost, except what was preserved by the cautious labours of Dr. Parker, who established the Medical Missionary Society, but who was only permitted to operate within the narrow limits of the foreign factories. In 1848 Rev. T. Gilfillan arrived there and commenced operations anew. The Rev. T. W. Pearse is now in charge of the work.

The record of the London Missionary Society, in regard to Chinese missions, is a noble one. It has accomplished great things through its medical missions and its day and boarding schools for boys and girls, but chiefly it has given to China and the cause of universal missions scholars so learned, and ministers so zealous, as Dr. Legge and Dr. Chalmers and Dr. Griffith John, with others who are worthy successors of the great man whose name is the title of this volume, Robert Morrison. In connection with this society there are thirty-one ordained missionaries in China, with thirteen lady agents. There are eight ordained native ministers, and seventy-two unordained helpers. 
There are about four thousand communicants, and two thousand pupils in schools. When the difficulties of the position are all duly estimated, this must be reckoned a very wonderful result.

When China was opened in $184_{2}$, and missionaries began to settle there in large numbers, it was deemed needful to prepare a new revision or translation of the New Testament. A Committee of Delegates was appointed, representing different Missionary Societies, which began its labours in July, 1847. The acting members of the Committee were the Revs. Drs. Medhurst and Bridgman and John Stronach. They finished their work in two years. It was a scholarly production, clear and idiomatic in style, as well as being a faithful translation. In view of the success of the work, it was resolved to prepare a similar translation of the Old 'Testament. 'The Rev. W. Milne was added to the Committee, and the task was brought to a happy conclusion in 185.. Shortly afterwards a version of the New 'lestament in colloquial Mandarin was prepared. Soon after these important translations were finished the hand of death was laid upon Dr. Medhurst, the veteran head of the Committee. The British and Foreign Bible Society at once resolved to scatter the new translation broadcast. On the earnest appeal of the Rev. J. Angell James, one million copies of the New Testament were printed and circulated, and the Bible Society sent out agents to superintend and carry out the work of distributing and selling copies throughout the land.

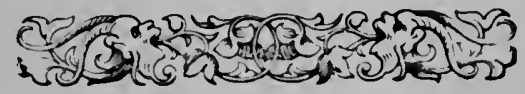




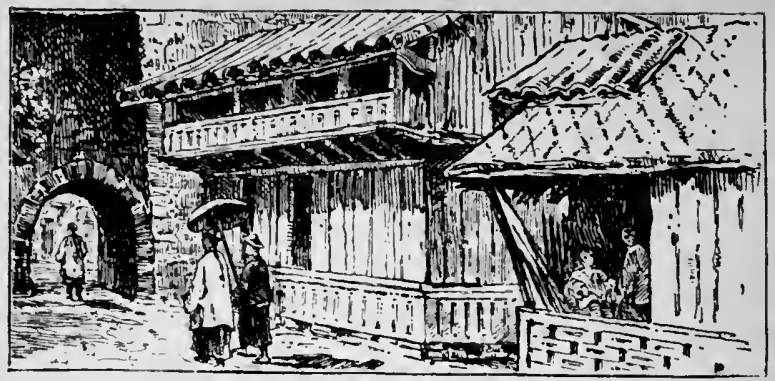

CHAPTER XVI.

CONTINUANCE OF THE WWORK: AMERICAN AND CONTINENTAL SOCIETIES.

"The hand of God sows not in vain;

Long sleeps the darkling seed below;

The seasons come and change and go,

And all the fields are deep with grain."-Lowell.

THE society which was the first to follow the example set by the London Mission in seeking to enter China was the Netherlands Society. It sent out Rev. Charles Gutzlaff in 1826, with some duties as chaplain under the Dutch Government. He reached Java in 1827 , but in 1829 he left the service, and gave himself largely to preaching, writing and distributing Christian books, visiting the ships in the seaports of Siam, Singapore, Macao, and other places. On the death of Hon. J. R. Morrison, he succeeded him as Chinese Secretary in the Government of Hong-Kong, which post he held till his death. He became a very expert Chinese scholar, and prepared a translation of the Bible. He also issued many historical and religious books, which prove him to have been a diligent student and industrious man. He was followed by Rev. Herman Röttger in 1832 , who laboured in Macao and Hong-Kong 
until 1846, when he retired, and the Netherlands Mission expired. Dr. Gutzlaff died in 1851 .

The Americans were the next to venture into the great field. The Board of Commissioners for Foreign Missions, representing the Congregational Churches of the United States, sent out Revs. David Abeel and E. C. Bridgman in 1829 , and who were received in February 1830 by Dr. Morrison. These devoted men assiduously laboured among the Chinese and Malays of the Straits Settlements, but from 1 $84_{2}$, up to his death in 1846, Mr. Abeel devoted himself to establishing a mission in Amoy, and the future success of the work of God in that city is largely due to his prudence and energy in its beginning.

The American Board followed up the appointment of these men with many others in rapid succession. Revs. I. Tracy and S. W. Williams, LL.D., followed in 1833 , and settled at Singapore and Macao. In the same year Revs. S. Johnson and S. Munson went to Bangkok and Sumatra, and up to the present time this Society has spared neither men nor means in order to follow up providential openings in the great dark empire. At present it has four great centres from which smaller stations are maintained. These are Foo-chow, in connection with which are fifteen churches; North China, embracing Pekin, Kalgan, Tientsin, Tung-chow, and Pao-ting-fus with smaller stations in the various districts of the centre missions; Shansi, with two stations in the midst of districts cursed by opium cultivation; and HongKong, where a missionary for the past seven years has resided chiefly to interview and seek to impress the multitudes of Chinamen going to and from the United States. At Tung-chow a college has been established, over which Dr. Mateer presides. Tung-chow is one of the centres for the literary competitive examinations of China, and therefore an important place. Dr. Mateer believed that the light of modern science shown in contrast with Chinese superstition would prove effective. He has, therefore, 
taught astronomy, mathematics, natural philosophy, and history, devoting himself, along with his helpful wife, to the young men and boys under his care. The result is that he has placed a stamp upon his young men, which makes them acceptable as teachers all over North China. 'The young men whom he has specially trained in Biblical instruction have proved the best material for a native ministry. Drs. Nevius and Corbett have co-operated in this latter work, by giving a theological education to candidates for the ministry during a portion of each year at Che-foo.

This Society has in connection with its principal stations large medical dispensaries and hospitals, boarding schools for boys and girls, colleges for native students, and other agencies for effecting the great purposes of the mission. It has twenty-eight missionaries, sixteen lady agents, ten medical missionaries, four ordained native ministers, one hundred and five unordained native helpers, nearly one thousand communicants, and four hundred and fifty pupils in its schools.

Other American churches speedily followed the example of the Congregationalist Board, and commissioned agents to go forth in their names to aid in the work of evangelising China.

The American Baptist Board sent out Rev. William Dean in 1834, who settled at Bangkok, but afterwards removed to Hong-Kong. Then in 1835 the American Episcopal Board sent out Rev. H. Lockwood, who went to Batavia, and in 1837 the American Presbyterian Board designated Revs. R. W. Orr and J. A. Mitchell to go out to Singapore. These societies have vigorously prosecuted the great work, and at the present time have a large aggregate of labourers on their various missions. The Baptist Board has sixteen agents at work in Ning-po, Swatow, and other places, and six other Baptist Associations have stations and missionaries in the land, although one or two are in a very feeble condition. 


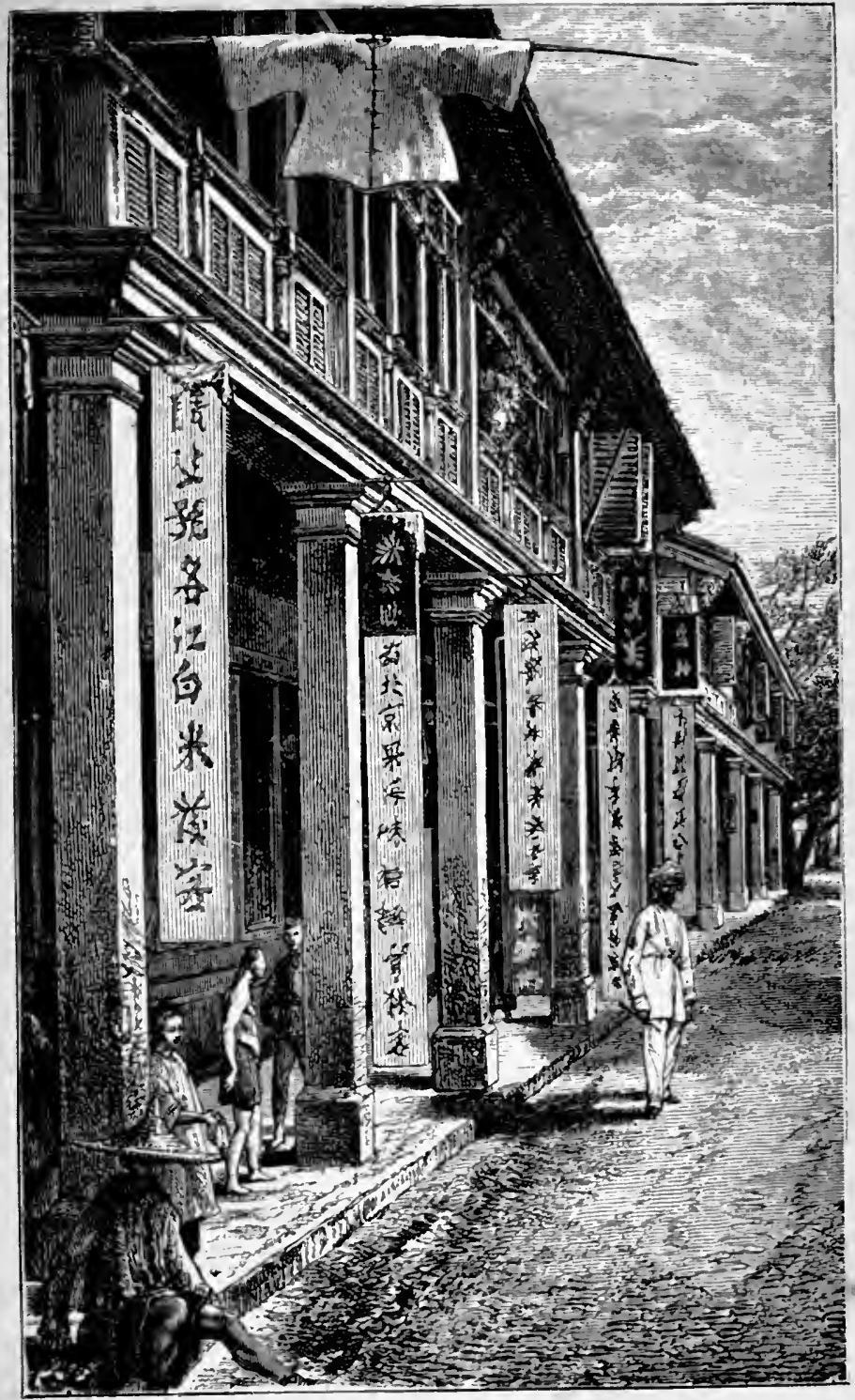


The Protestant Episcopal Mission has its headquarters in Shanghai, where it maintains a very efficient staff, and does a good work. Following Mr. Lockwood, Rev. W. J. Boone, D.D., went out in 1837 to Batavia. He afterwards removed to Amoy, but in 1843 he was appointed to Shanghai, and made the missionary bishop of China. Speedily, boarding and day schools were established, a medical hospital opened, and Dr. Schereschewsky was set apart to prepare a new version of the Holy Scriptures, in the Mandarin dialect, which he completed in 1875 . There is also in Shanghai a medical school for the training of native physicians, surgeons and nurses, and a college for the training of native missionaries. There are other stations at Wuchang, Hankow, Che-foo, and Pekin, which, including those at Shanghai, comprise forty-three places of worship, ten missionaries, three medical agents, three lady agents, seventeen ordained native ministers, three unordained helpers, and about five hundred communicants.

The Presbyterian Board of America transferred two of their missionaries from Singapore to China, in 1843 . It has now four great centres. Canton was entered in 1845 , but it was sixteen years before they were able to baptise the first convert. Now upwards of four hundred in that city reward the persevering faith of the patient workers. A medical hospital is a very important factor in the work of the Mission. Missions in Macao and Hainan are sustained from this centre. Hospital work has been a prominent feature in this Mission. Dr. Peter Parker commenced a hospital in 1835 , which was transferred to this society in 1854 , and placed under the care of Dr. Kerr. The Central Mission has five main centres which branch out in many directions. These include Ning-po, Shanghai, Hang-chow, Foo-chow, and Nanking. At Shanghai the extensive printing operations of the Society are carried on. These comprise not only several presses which are constantly at work, but a foundry where seven sizes of 
Chinese type, besides English, Korean, Manchu, Japanese, Hebrew, Greek and others, are cast. There is also complete apparatus for electrotyping and engraving. Much splendid translation work has been done by this Socicty, and handbooks of Christian history and doctrine prepared by it are in use on most of the Protestant missions in the land. The Shantung Mission extends from the capital city, Chinan-foo, northwards to Che-foo, and has many stations which report about three thousand members. The Pekin Mission is of latest date, and is doing much work in diffusing throughout a wide district a knowledge of the Gospel by its carnest proclamation of the truth to the vast numbers who crowd from all the surrounding regions to the imperial city. The totals of the mission are, forty-eight missionaries, eighteen lady agents, twenty-three ordained native pastors, eighty-four unordained native helpers, and nearly four thousand communicants.

The American Presbyterian Board was followed, in $18+2$, by the American Reformed Church (1)utch). It has now seven missionaries and one hundred and fourteen unordained native helpers, working with Amoy for head centre, with about fifteen associated churches. In $18+7$, the American Methodist Episcopal Society (North) entered the field, and has surpassed all others in the number of its agents and members. Its pioneer was Rev. Judson D. Collins, who passionately besought the society to enter China. When he was told that no money was available for the purpose, he wrote: "Engage me a passagc before the mast in the first vessel going to China. My own strong arn can pull me to China and can support me when I arrive there." Such enthusiasm was irresistible, and Mr. Collins was sent to Foo-chow, where, after ten years' weary preparation, a splendid work broke out, which has spread itself over six large districts, and comprises sixty stations. A printing press is kept busily employed, which, in the year I 888 alone, issued $\mathrm{r}_{4}, 000$ pages of Christian literature. A 
large college is in use through the generosity of a native gentleman. The mission also winds along the banks of the Yang-tse-Kiang for three hundred miles, and has stations in Nanking and other large cities. Northwards it has churches in Pekin, Tientsin and Isunhua, with full accompaniments of schools and hospitals, and it extends westward to Chung King, I,400 miles from the sea. It has thirty-two missionaries, seventeen lady agents, forty-three native ordained pastors, ninety-one unordained native helpers, and over four thousand communicants.

'Two Baptist Societies already named followed in chronological order from America, and in 1848 , the Methodist Episcopal Church (South) followed the example of its sister denomination of the north, and sent out its agents to Shanghai, where they have since laboured, extending to several neighbouring cities. They have ten missionaries, fifteen lady agents, and employ one hundred and ninetyeight native workers. They maintain a college at Shanghai, and do much dispensary and hospital work.

Later missions from America have been established, as, the Presbyterian Board (South) in 1867 , the Canadian Presbyterian in 1871 , the American Bible Society in I876, the American Scandinavian Congregational Society in 1889. These young recruits in the field are occupying many important spheres and give promise of much development.

It may be convenient here to notice the Continental societies which have contributed their forces in the attack on Chinese heathenism. In 1847 , missionaries from the Basle Evangelical Mission arrived at Canton. These were the Rev. T. Hamberg, who died in 1854, and the Rev. R. Lechler, who still lives to superintend the work. Eleven churches exist around Canton as the centre, and much money and labour have been expended in the production of Christian tracts, school books and handbooks of doctrine. 
In the same year, the Rhenish Mission sent Revs. W. Koster and F. Genaehr to China. They settled at Canton, but the mission has experienced much difficulty and discouragement. It has four missionaries, three lady agents, cight unordained native workers, and numbers about one hundred and fifty members.

The Berlin Society sent agents to China in $185^{\circ}$, and some standing was preserved by them till 1873 , when the work scemed to expire. But in $\mathrm{r} 882$ another effort was made to occupy the field, and now threc central stations are opened, four foreign missionaries are at work with thirtyfive native agents, and about five hundred communicants have been gathered.

The Berlin Foundling Society has also established a benevolent mission in Hong-Kong, where Rev. F. Hartman, assisted by four lady agents, is carrying out earnest labour. This institution was established in 1850 . Dr. Gutzlaff visited Berlin in that year, and gave such a graphic account of the distressing misery existing in China, that the wife of a Lutheran pastor, named Knack, resolved to seek to alleviate it. Dr. Gutzlaff had spoken of the great number of infants cast away by their parents in China, and Mrs. Knack formed a ladies' association to organise a plan to rescue some of these foundlings. A house was rented in Hong-Kong, and a commencement made. Not many children were found in Hong-Kong, but many were brought in baskets from the country districts of China. Some were in such a reduced condition when they were received that they speedily expired, but soon a large number were received and placed under instruction. In $186 \mathrm{I}$ new and enlarged premises were built, the funds being supplied by foreign residents in Hong-Kong and by benevolent donors in Germany. In the course of twenty years three hundred children were received, but of these a considerable number died. They receive careful religious instruction, and learn to read and write. They are taught arithmetic, geography, history, and 
singing. They learn also to perform all household duties. The school is under Government inspection, and the girls have acquitted themselves well in the examinations. The girls have generally turned out well, some having married native Christians, some being school teachers, and others having gone to other countries. It is pleasant to think of these castaways being rescued and trained to become jewels in the crown of the Lord Jesus.

In 1884 the General Protestant Evangelical Society of Germany sent Rev. E. Faber to Shanghai, where he is working alone.

Thus it will be seen that extensive and variously adapted means are being freely used, in order to extend the Gospel in China by the societies of America and the Protestant countries of Europe, and it is not to be doubted but that, as the sore needs of the vast populations of the enormous cinpire make themselves felt, the Christian conscience will vibrate more adequately to the call of duty, and the instrumentalities, already in operation, will be multiplied manifold. It is fitting now that a slight review should be taken of the work being done by British Societies.

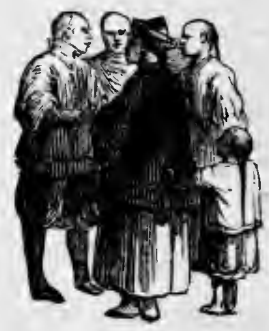




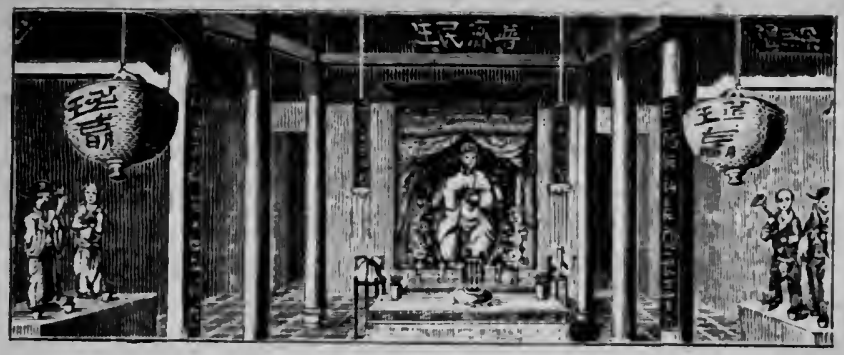

\title{
CHAPTER XVII.
}

\section{CONTINUANCE OF THE IVORK: BRITISII SOCIETIES:}

\author{
"Fall warm, fall fast, thou mellow rain; \\ Thou rain of (iod, make fat the land; \\ That rocits which parch in burning sand \\ May bud to flower and fruit again."-KiNGsLeY.
}

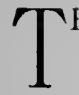

HE first British Socicty to follow in the footsteps of the earliest and pioneer agents was the Church $\mathrm{Mis}$ sionary Society, which sent out its messengers soon after the opening of the Empire after the treaty of Nanking. Shanghai was first occupied by these agents, then Ning-po, then Foo-chow, afterwards Hong-Kong and Pekin, more lately in succession Hang-chow, Shaou-hing, and Canton. The work in Foo-chow and neighbourhood has becn especially encouraging. Eleven years passed without one soul having been converted, and dtiring that period two missionaries had died and two had retired, leaving only one in the field. Then promise of a harvest was given, and during the past twenty-five years more than seven thousand have professed conversion in one hundred and thirty towns and villages where preaching of the Gospel has been established. Very much of the work is done by 
native evangelists, and, in order to train these, a theological college has been established, besides several boarding schools. Medical missions are also carefully cultivated. Similar happy results are reported from Ning-po and Hangchow. At the latter place, in addition to the usual mission operations and agencies, there is an opium refuge provided, to which even the mandarins of the city contributed. This Society has published many portions of the Scriptures, the Prayer Book, and other Christian books in Roman character in several of the dialects spoken in the localities where its missions are situated. It has twenty-eight missionaries, five lady agents, eleven ordained native ministers, eighty unordained native helpers, two thousand eight hundred and thirty-two communicants, and two thousand and forty-one pupils in its many schools.

The Baptist Missionary Society entered China in I 845 , when the Revs. T. H. Hudson and IV. Jarrom went to Ning-po. In this connection it may be mentioned that the earliest missionaries of this Society when in India had intense interest aroused in their minds in behalf of China, inasmuch as Dr. Marshman became an expert in the language, translated the Bible into Chinese, prepared a grammar of the language, and translated the works of Confucius into English. The mission attempted in 1845 lingered feebly and cxpired for a time, but in 1877 a new commencement was made, and a useful work has been done in the provinces of Shansi and Shantung. This Society is laying deep foundations of future usefulness by paying earnest heed to the training of native evangelists. Medical missions are'also engaging its attention. It has now twenty-one missionaries in the field, with one ordained native pastor and eight unordained native helpers. It numbers nearly twelve hundred communicants.

The Presbyterian Church of England resolved to establish a mission in China in 1847 . The services of the liev. William Chalmers Burns were accepted, and he went 


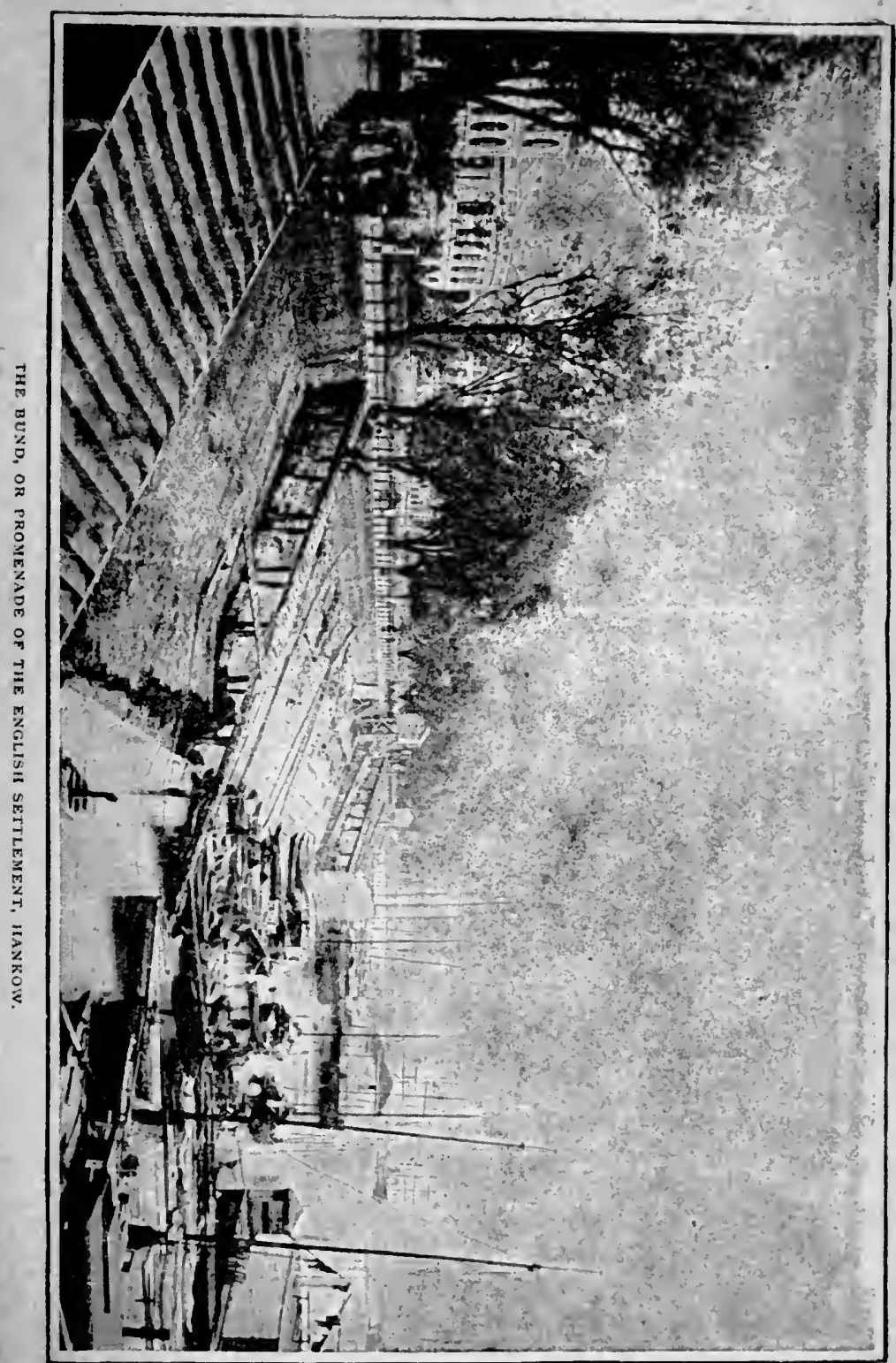


forth, residing first at Hong-Kong and then at Amoy. 'Ten years later he was joined by the Rev. George Smith. Mr. Burns was a man of flaming zeal and devotion; and, along with his colleague, amidst inauspicious circumstances and many disappointments, laid the foundation of what is now one of the most extensive and prosperous missions in the Empire. Its principal centres are Swatow, Amoy, and Tai-wau. It has several most complete and beautiful establishments, combining churches, mission houses, hospitals, and schools, and spends money freely in carrying out every department of operation. The senior missionaries in the field are Rev. H. L. Mackenzie, M.A., of Swatow, and Rev. W. McGregor, M.A., of Amoy. Rev. George Smith, the coadjutor of Mr. Burns, died only last February (r8gr), and was a man of sterling qualities. This Society is greatly aided by a women's association, by which female agents are sent out from this country. Several of these have certificates for the practice of midwifery, and possess a general practical knowledge of medicine, being thus able to alleviate the sufferings of the native women to a very considerable degree. It has one hundred and six stations in China and Singapore, and employs fifteen ordained missionaries and medical workers. It has nine lady agents, five ordained native pastors, and ninety-three unordained native helpers. It numbers nearly three thousand six hundred members, and has four hundred scholars in its training schools.

The Wesleyan Missionary Society sent out Revs. W. R. Beach and J. Cox to Canton in $185^{2}$. It afterwards established itself in Hankow, and has now its principal stations in that city and others of the province of Hupeh. Lay agency, under the direction of Rev. David Hill, is a prominent feature in the Mission at Hankow, and this Society is also trying the experiment of giving to some of its missionaries a medical training, that they may combine preaching and healing gifts in their labours. The result of these 
experiments will be looked for by other societies with much interest.

In 1884 it resolved to open a college or high school in connection with their Central Mission, and the Rev. IV.

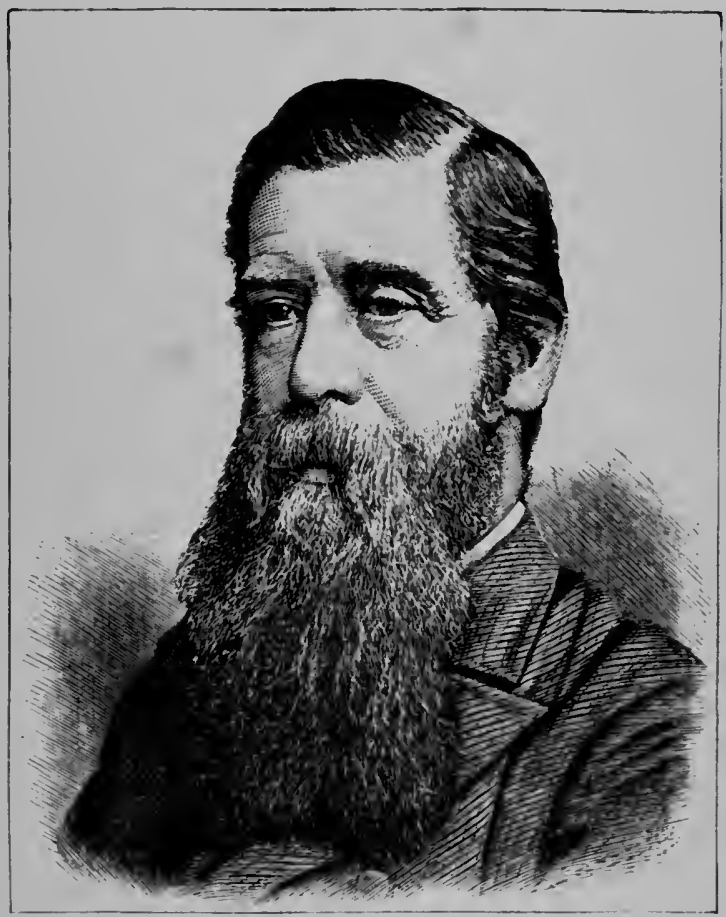

KEV, J, INNOCENT.

T. A. Barber, M.A., was appointed principal, and arrived at Hankow early in $\mathbf{1} 885$. The object of the institution is to provide a liberal Western education for the sons of official and other wealthy Chinamen. Attempts to purchase land for the erection of a suitable building were unsuccessful, 
but in 1887 a large house was rented in the main street of Wuchang, and the work begun. It is proceeding with growing success, and much may be expected from it both directly and indirectly to benefit the work of the Mission.

A ladies' auxiliary society interests itself in sending out female workers, and almost every branch of the Mission is encouraging. There are twenty-five missionaries at work, with six lady agents, two ordained native pastors, thirty-three unordained native helpers, and nine hundred and seventyfive communicants.

The Methodist New Connexion entered China in I 860, immediately after the close of the second opium war, and after the signing of the Tientsin treaty, which virtually opened all China to the Christian agent. The pioneers of the movement were Revs. J. Innocent and W. N. Hall, who established themselves in Tientsin, which was then virgin mission ground. Mr. Hall died of fever in 1878 , but Mr. Innocent still survives, and is the Nestor of the Mission. There are three preaching rooms in the city of Tisntsin, one being in the main thoroughfare, and in these daily preaching is kept up. On the English concession there is a large mission establishment, consisting of a training college for native students for the ministry, missionaries' houses, and a boarding school for the training of native women and girls in Christian life and work. Rev. J. Robinson is the principal of the college, and Miss Waller is in charge of the girls' school.

The largest mission of this Society is in the north-east portion of the province of Shantung, where about fifty native churches are maintained in an agricultural district extending over about three hundred miles. The headquarters of this circuit are in Chu Chia, Lao-ling district, where are situated the mission houses, and a medical dispensary and hospital. Mr. Innocent is at present the head of this circuit, and the hospital is in charge of Drs. W. W. Shrubshall and F. W. Marshall. In this place also is located Rev. J. K. Robson, 
who has devoted himself to the work of the Mission at his own charges.

More recently a new mission has been opened at the Tang-san Collieries, near Kai Ping, in the north of the province of Chih-li. 'This is under the charge of Rev. F. B. Turner, and is rapidly extending, having a cluurch in the ancient city of Yung-ping-fu, near the old wall, and also several rural chapels in the district round Kai Ping.

The work of this Society is chiefly carried on by native agency; a large number of efficient men have been trained and qualified by means of the training college. Several pious native women are also set apart as Biblewomen to their own sex; one of these, Mrs. Hu, has laboured in this capacity for nearly twenty-five years, and was the first such agent ever employed in China. This Mission now numbers seven missionaries, two medical agents, one lady agent, forty-six native helpers, and six female native helpers. It has over thirteen hundred communicants, and about two hundred and fifty scholars in its day and boarding schools.

The United Presbyterian Missionary Society of Scotland sent its agents to China in 1864 . Work was commenced at Ning-po, and afterwards extended to Che-foo, but latterly these stations have been left, and Manchuria has become the special sphere of the Society. 'The Rev. A. Williamson, L.L.D., is the patriarch of the Mission, having been in China since 1855 , working in various departments. He has of late years devoted himself entirely to literary work, and has prepared some books of Christian history and doctrine, which must in the future be important helps to Chinese students and converts. The work in Manchuria has been remarkably successful. The Revs. J. Ross and J. M[cIntyre, who went out in 1872 , are at the head of the two great centres of operation, Hai-chung and Moukden. A medical hospital is in operation in each of these places. Mr. Ross has lately completed a translation of the New Testament into the Corean dialect, and from this Society useful work 
in Corea is to bé expected shortly. There are seven missionaries employed, one lady agent, fourteen native helpers, and about eight hundred communicants are reported.

The China Inland Mission commenced its extraordinary history in $\mathbf{8} 865$. The chief instrument in the formation of the Mission, under God, was Rev. J. Hudson Taylor, M.R.C.S., who in 1853 went to China as a medical missionary in connection with the Chinese Evangelisation Society. He separated himself from this Society in 1857 , and in 1860 he returned to England in broken health. He had for some time been in charge of a large hospital in Ning-po, and the heavy strain of being alone in such an institution completely prostrated him. As he sailed homewards he was intensely anxious about China, and fervently prayed that God would cause his return home to forward the conversion of the Empire. He specially asked that he might have five labourers given him for Ning-po, and the province of Che-kiang. He had already written to a friend in England asking if he knew of any earnest devoted young men who, not wishing for more than their expenses, would go out and labour there. On his arrival in England he soon met with several young men who were willing to undertake work on such terms as he could offer. Mr. James Meadows was the first to volunteer, and he with his young wife sailed to Ning-po in I 862 . The five workers first asked were obtained, and then Mr. Taylor felt that his faith was enlarged to ask for and expect larger blessings from God. Therefore he asked for twenty-four more labourers to enter the interior, which, with the exception of Hankow, was as yet untouched by mission effort: This led to the formation of the Inland Mission. In commencing a new association for the conversion of China, Mr. Taylor was anxious not to interfere with any of the existing Societies, but the need of increased effort and agency was painfully evident, from the fact that in 1865 there was only about 
one missionary in the country to every three millions of the population, and that eleven out of the eighteen provinces were as yet unvisited by any Christian agent. 'The Inland Mission was commenced on these principles: $(a)$ 'That the agents should be employed without reference to their denominational attachments, only provided they believed the truths accepted by Erangelical churches; (b) that they should go out in dependence upon God for their support, without any guaranteed income, and knowing that the Society could only maintain them so long as its funds permitted; $(c)$ that there should not be any collections or personal solicitation of money.

Mr. Taylor sailed for China in 1866, with fifteen missionaries. This was the real commencement of this wonderful movement. Since that time the Mission has extended in every direction. It has established itself in fifteen provinces. It has ninety-one principal stations, and about as many out-stations. Its income for the first ten years averaged $£ 5,000$ per annum, but it has risen of late years to from $£ 30,000$ to $\mathcal{L}_{40,000}$ per annum, and the mission staff has multiplied from fifteen in $186_{5}$ to four bundred and twenty-four in $\mathbf{I} S_{9} \mathrm{r}$, including the wives of missionaries, many of whom were already employed by the Mission, and still continue their labours. 'The agents have been drawn with remarkable impartiality from every Protestant conmunity; and while many of them are of the poorest in condition, some of them are both wealthy and of high social standing, who have gladly maintained themselves, and in addition have contributed largely to the general work. In the year i $888 \mathrm{Mr}$. Taylor made a special appeal for one hundred missionaries, and during the year had the pieasure of seeing his prayer gratified, for more than the number asked for were forthcoming. Besides the immense number of agents directly connected with this association, there are seven societies, chiefly Continantal, which maintain seventy-nine missionaries, who work under its direction. The 
number of communicants counted is under three thousand, which if less than is returned by some Societies who employ but a tithe of the agents of the Inland Mission, is yet a return to be thankful for, considering the enormous difficulties encountered by the missionaries in breaking up fresh ground in the interior, in having untold opposition to encounter from those to whom the very sight of a foreigner was a novelty and a scandal, and also from the fact that many of the agents of this Mission have been itinerating preachers, passing from town to town and village to village with the message of the Gospel, rather than settling down as pastors and teachers after the manner of other. Societies. The facts above recorded have been principally gleaned from "China's Spiritual Need and Claims," by J. Hudson Taylor. Mr. Taylor has been nobly seconded in his efforts by Mr. B. Broomhall, the devoted secretary of the Society.

The United Methodist Free Churches entered China in 1864 , Rev. W. R. Fuller being the first agent. He settled in Ning-po, and was shortly afterwards joined by Rev. J.

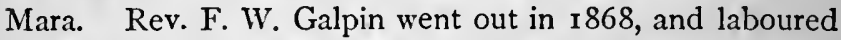
in Ning po till I89o. In I89 I Rev. R. Swallow was appointed to the same place. In ${ }^{8} 88_{7}$ Rev. W. S. Soothill went to Wan-chow, and has recently been able to record a large number of interesting conversions. This latter Mission experienced a severe trial in $\mathbf{r} 888$ by the Chinese wrecking its premises, along with other foreign property, in rioting arising out of the war with France. Compensation was fully made by the Government, and more eligible premises were secured. There are three missionaries, two ordained native pastors, eight unordained native helpers, and about three hundred and fifty members on the Mission. Rev. R. Swallow combines medical work with his ministerial labours.

The Society of the Irish Presbyterian Church began work in China in 1869. It has chosen Manchuria as its sphere; and its agents, from Neu-chwang as their head- 
quarters, take long evangelistic journeys northwards, and are arranging to settle in some of the large towns they have visited. There are three missionaries and one medical agent, and nine unordained native belpers at work, and twenty-eight members are recorded.

The Society for the Propagation of the Gospel in Foreign Parts has attempted work in the Straits Settlements for many years, but only in 1874 did it seek to establish itself in China. It has appointed a Bishop of North China, with four helpers, and is training a number of young men for missionary work. Several other Societies have also recently entered the Empire to aid in its evangelisation; among which maybe enumerated the Established Church of Scotland, which commenced in 1878 ; the Bible Christians, who entered in $188_{5}$, and work in conjunction with the China Inland Mission; the Society of Friends, who sent one agent in $\mathrm{I} 886$, and a few others. All this activity shows the widespread interest China is arousing in the Christian Church, and how properly its conscience is responding to its claims.

It would not be right to omit reference to the wonderful work being done in behalf of the blind of China by Mr. W. H. Murray, of the Scotch Bible Society. He went to China in $\mathbf{I} S 7 \mathbf{I}$; but knowing that there are immense numbers of blind people in that land, before he went out he studied the systems of Moon and Braille for reading and writing by the blind, and also took lessons in Bell's system of visible speech. On arriving in China he found that the latter system aided him in acquiring the Chinese language. He carefully noted every sound he mastered, and reduced them to the number of four hundred and twenty. Meeting with crowds of the blind at every turn of his work, he became possessed of an intense longing to alleviate thcir hard lot by teaching them to read. He set to work to reduce these sounds to a system of dots after Braille's system, and after numberless experiments succeeded 
in forming a category of signs to represent the sounds of the language. Then he sought out a subject on whom he might try his system. He took a little blind orphan beggar who was lying almost naked in the streets; he washed and clothed him, and offered to house and feed him if he would try to master his teaching. The boy was delighted with the change in his condition, and in six weeks, to the mutual joy of master and pupil, the child was able to read both fluently and accurately. Then two blind beggar men were induced to learn, the boy acting as teacher. One read well in two months; the other not so quickly, but with great pleasure. Miss Gordon Cumming says it was intensely pathetic to stand at the door of a dark room and hear these men read the words of Holy Scripture, who four months before had sat in misery and rags, begging in the streets. For more than sixteen years Mr. Murray has pursued his work among the blind, and many of his pupils have become earnest Christians and respectable citizens through his instrumentality. While he has been pursuing this novel method of doing good, he has diligently performed his duties as a colporteur of the Bible Society of Scotland, and has taught his pupils in hours stolen from sleep. He has also denied himself at every end to provide board, lodging, and raiment for his ragged regiment of blind students. A special blessing has been conferred by him on a number of blind women he has taught to read, who have thus had not only a new charm given to their own lives, but have become centres of interest and living power as readers of the Bible to their friends and neighbours. 


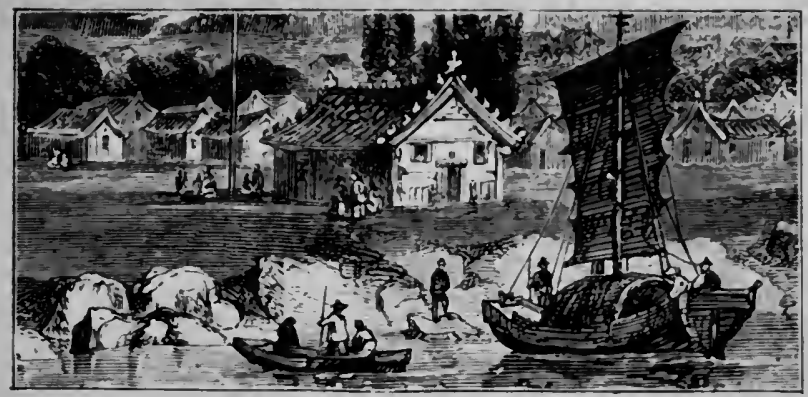

CHAPTER XVIII.

THE OPIUM TRADE OF CHIVA.

"Man"s inhumanity to man

Makes countless thuusands mourn."-Bukss.

THERE is one evil in China which it is important to speak of, as being a dire foe to the welfare of the people, and an enormous hindrance to the progress of missions. It is the use of opium. Opium is made from the juice of the poppy head, and although it has a place as a medicine, when it is taken habitually it becomes the most frightful curse to the man who becomes its victim. It masters both body and mind, paralysing the one and gradually destroying the other. It deadens the conscience so entirely; that a man will sacrifice his mother, wife or child in order to gratify its insatiable cravings, and will commit any deadly crime sooner than be deprived of it. This curse has so spread itself in China, as to threaten the happiness of the nation throughout its whole extent.

About a hundred years ago opium was almost unknown in China. It was then brought in the ships of the East India Company, and offered for sale. Some of the natives began to smoke it, not knowing its deadly nature ; and being delighted with its soothing influence, they bought it readily. 
This encouraged the foreign traders to bring more, and so gradually the poison obtained a footing in the land.

When at last the Emperor and statesmen found out the harm opium was doing, a law was passed that no one was to buy, sell, or use it under penalty of death, and for a brief time the traffic was stopped. The mandarins of China are proverbially corrupt; and when bribes were offered them by English merchants to permit the entrance of opium into their ports, they accepted the bribes, and thus the buying and selling of the drug still went on. Then smuggling sprang up and prevailed extensively; British ships brought the opium within easy reach of the shores of China, and Chinamen went out in boats, which were rowed with many oars, and brought the fatal drug to the land. This became known to the Government, which issued strict orders to the mandarins, commanding that the smugglers should be seized and imprisoned or beheaded.

The English merchants had now discovered what a source of wealth opium might become to them ; and, as the strictness of the Chinese Government made smuggling difficult and dangerous, they armed with guns and soldiers small strong boats, and sent them up to Canton, offering larger bribes to the mandarins, and thus still forcing their nefarious traffic upon the people. At last the Emperor became so incensed that he sent a Special Commissioner from Pekin to stop the trade in opium. This man boldly grappled with the evil. He shut up the English merchants in their houses, seized twenty thousand chests of opium at the island of Lintin, at the mouth of the Canton river, and threw them into the sea. The East India Company resented this action, and, being sustained by the British Government, war was declared against China, and a cruel, bloody, disastrous war it proved to the unfortunate heathens. When at last peace was made, the Chinese were condemned to pay a fine of twenty-one millions of dollars, including six millions of dollars for the opium which had been destroyed. 
Then a proposal was made to the Emperor that opium should be admitted into China, and that he should share the revenue obtained from its sale. The proposal was indignantly rejected, and, with a magnanimity worthy of imitation by some so-called Christian potentates, he said he would not become rich by destroying his people.

Two wars afterwards broke out between the English and the Chinese, in which the former were again victorious. Then the Emperor was obliged to sign a treaty making it lawful to bring opium into the Empire. The English would only permit a small tax to be placed upon it, which was insufficient to materially check its use. Thus the weak and helpless natives have been dragged into the use of this poison, which, when once used, creates such a craving for more that men and women speedily become slaves to its use.

The opium that is most largely used in China is grown in India, and the money obtained by its sale in China helps largely to maintain the British Government of that empire. The opium traffic with China is not like the accursed drink or gunpowder trades with the barbarous tribes of Africa, because these are carried on by private individuals or companies, and neither the Government nor the people who support the Government are directly responsible. Nor is the opium trade like the drink traffic in England, because, although the Cluurch of England is a large owner of publichouse property, and many professing Christians stain their hands and consciences by engaging in the traffic, yet the Govermment does not carry on nor maintain breweries or distilleries or public-houses. But the British Government in India is responsible for the opium traffic. It advances the money for its growth and cultivation; it receives and manufactures the juice into opium, and the sale of it is a Government monopoly, from which it draws an annual revenue of five millions of pounds. It has spent millions of money and thousands of lives in keeping the ports of 
China open for its sale, and insists still upon the necessity of persevering in the trade because it cannot do without it. In vain Christians and philanthropists denounce the traffic the wide world over; in vain Chinese governments entreat and bewail and seek to check the demoralisation of the people. Every consideration is of no avail when five millions of pounds is concerned for the support of the Indian Government.

The influence of this diabolical trade upon the work of the missionary in China is distressing. It is the most gigantic stumbling-block in the way of the Gospel of Jesus Christ. As the missionary preaches the Gospel of peace and love in the city chapels or at fairs and festivals, as he denounces idolatry in the native temples, he is raked with questions as to the opium wars, as to the destruction of the people by a drug which "Christians" have introduced and forced upon them, and is reproached with the ruin manifestly spread through the land by this awful vice.

Now, opium is being cultivated largely in China itself. The quality is not so good in the judgment of opium smokers as that produced in India; but as the vice increases amongst the people, and the habit weakens the perceptive power, the coarser and cheaper quality comes to be used, and thus China is learning to furnish itself with the means of its own destruction. The only possible antidote to the evil is the restraining power of the Gospel ; the only compensation which England can make to China for the ill it has done through the introduction of this vice is to insist upon the stoppage of the traffic, even if the deficiency in the Indian revenue has to be made up by the British taxpayer, and then to multiply Christian agents and agencies, until by the preaching of the Gospel and the power of the Holy Spirit the evil is retrieved and the land is purified from the great curse.

In the month of March of the present year, a convention was held in London by Christians of every branch of the 
Church, including delegates from all parts of the United Kingdom and from Holland, to consider the evils of the opium system, and how to remedy them. One day was devoted to fervent prayer for Divine direction, and three days were spent in solemn and devout discussion of the subject. Forty-five thousand ministers about the same time called the attention of their congregations to the results of the evil thing, and finally a fund for $\chi_{20,000}$ was conmenced to carry out by pen and voice an undying crusade against its continuance. The moral power of the council has already made itself felt, for shortly afterwards a majority of the House of Commons voted in favour of the motion of Sir Joseph Pease, that it was inexpedient any longer to maintain the traffic in opium, simply for the purpose of sustaining the Indian revenue. It becomes now the duty of the Government to consider in what way the decision of Parliament can be carried out, and it becomes the duty of every Christian to use his influence and insist that it shall be carried out.

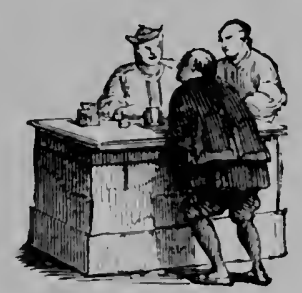




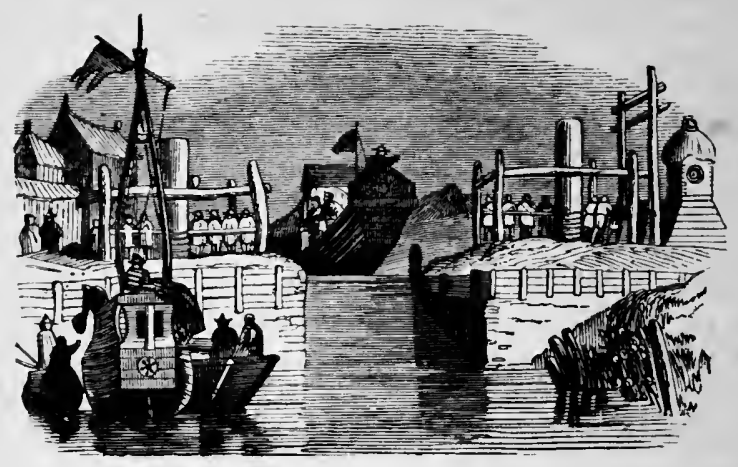

CHAPTER XIX.

\section{CHINA FOR CHRIST.}

"Oh! mighty King of glory,

Thy chosen heralds send

To tell the old, old story

To earth's remotest end.

Give hearts of love and pity,

And willing, zealous feet,

Through forest, plain, and city

Thy mercy to repeat."

$\mathrm{W}^{\mathrm{r}}$

E need an army of workers in China. We must have a large brigade of our noblest youths for the great work waiting for labourers over there. IVe have hundreds of young men and women, the children of rich and well-to-do people, who have no special work in life, and to whom life will be a humdrum monotony, bringing little joy and no growth to the higher nature unless they rouse themselves to sublime and self-sacrificing work in the Lord's Harvest Field. Will their parents and friends consent to their being devoted to a calling as grand and inspiring as ever called Paul to the "regions beyond," or Wesley to labour so zealously for the semi-barbarous and totally degraded masses of England in the last century? 
It is a fact that hitherto all the efforts of the Christian world for China have only resulted in supplying one missionary for 350,000 souls. Take the province of Chih-li; the whole Protestant force is only forty, or one missionary to 675,000 souls. If we had the means we could place in the unzerked portion of this province 150 missionaries, each one having a radius of twenty miles as his circuit of operation.

This great nation cannot wait indefinitely. While we are lingering, all the evil forces of the world-infidelity, gambling, licentiousness, idolatry, opium-smoking, spiritdrinking, and a host of others-are vigorously at work, and unless Christians wake up to this terribly vast responsibility, we shall have China waking up from its long sleep of twenty centuries only to plunge into an abyss of atheism and immorality the depths of which can never be sounded. Every minute that the Church delays responding to the cry of China, twenty-four immortal souls sink into a Christless grave ; every day's delay means 35,000 more who have gone; every month's delay means one million, whom Christ died to redeem from sin, who have gone into the great future without having received the glad tidings of great joy.

The people are willing to listen to the Gospel. If they are slow to receive it, they hold it the more firmly when it is received. The Chinese character, when it is truly converted and sanctified by the love of Christ, is a noble one ; and while the cry for help comes to us from China, it also comes to us from the Master who has thrust us into the great harvest field and given us such pre-eminent success therein.

In the readiness of the people to hear the Gospel we have great encouragement to persevere; for that mighty and alleffectual talisman which of old, in Greek and Roman cities, proved itself to be the "power of God unto salvation," has still "the dew of its youth" resting upon it, and as the gods of the Pantheon were not able to withstand its attack, so the gods of Buddhist and 'Taoist temples must also fall before it. 
"The idols $\mathrm{He}$ shall utterly demolish." "He shall dash them in pieces like a potter's vessel."

There is much encouragement to be found in the fact that the Chinaman, when he is converted, develops a Christian character and a firm adherence to principle which will bear comparison with the members of any church in the world. Trained to consider revenge a Divine quality, Chinese converts have manifested a meekness and forgivingness of disposition truly admirable; educated in pride and conceit, they have become as docile as young children; covetous and deceitful, taught to consider lying and stealing a virtue, they have showed willingness to suffer persecution and to endure death itself rather than deny their Master or turn from their faith. Two or three examples may be given out of hundreds that are ready to hand, and which the piles of modern reports plentifully supply. Indeed, few more charming and inspiring books could be produced than one filled with such examples of grace as Chinese missions have recorded.

Mr. Wang was a magistrate and scholar residing in a large city in the north of China. He was over sixty years of age when he was taken with a serious illness. In the course of this sickness a friend came into his house one day and said, "See, the foreign teachers in the city have given me this book. Now, I don't care to read it, but you are a great reader, and $I$ have brought it you to read during your sickness." The old man took the book and carefully examined it. It was a Bible in the Chinese language. He read it, and was deeply impressed with its contents. He was not able fully to understand it, and when his friend called upon him shortly afterwards he said to him, "Will you ask those foreign teachers to give me something to explain that wonderful book you brought me?" His friend did so, and was supplied with Dr. Martin's handbook of Christian truth, which is kept on several missions in China to be placed in the hands of 
inquirers. Mr. Wang eagerly received this book, and as he examined it and compared it with the statements of the Bible the darkness began to pass from his mind. $U_{p}$ to this time he had been a proud Confucianist, but now he firmly grasped these two foundation truths of religion: (a) that there is one God, the Almighty Maker of heaven and earth; and $(b)$ that $\mathrm{He}$ is willing to hear and answer prayer. Under the influence of these great truths, the next time his native doctor called upon him, he told him he would not require his services any longer, that he had called upon the Almighty God of heaven to cure him, and that $\mathrm{He}$ would answer his prayer. Upon his recovery he repaired to the hall where the daily preaching of Christ and His salvation was maintained in the city. He listened to the message as one entranced. He remained behind the congregation as an inquirer, and, like many other Chinese convert, she asked questions without end, going down to the roots of things with scholarly acuteness and satisfying his mind step by step for many days. At last his scruples and difficulties were all removed, and with the simple faith of a child he rested himself on Christ for full salvation. In the eagerness of his new-found peace he declared himself a Christian to his family and friends. But now came the trial of his faith. All his relatives and his friends turned against him. $\mathrm{He}$ was degraded from his place on the seat of justice; he was not allowed to associate with his literary friends; his very children rose up against him and expelled him from home, a step in a country where reverence for parents is the first law of life, which shows the extreme to which religious persecutions may be carried : but none of these things moved him. He found refuge in the Mission premises, and gave himself to preparation for the work of an evangelist. Soon he proved himself an earnest and effective preacher of the Gospel, and for years stood up boldly declaring Jesus to be the Friend and Saviour of sinners, always setting forth himself as being the subject of His power to save. In this 
way he wrought, preaching in public halls and in the open air until the infirmities of old age made such exercise too much for him. Then he devoted himself to the preparation of a book on Christianity, which he entitled "The Bright Lamp of the Heavenly Way." As he concluded his task his strength failed and his end drew near. He called the missionaries of the Societies represented in the city to his side, and bade them farewell; he confessed again his undying faith in Jesus. To one of them who was about to return on furlough to England he urged his request that he would tell his English friends who had sent him the message of Divine peace that he would wait for them at the door of heaven, and when they arrived there he would lead them to the throne and say to the Saviour, "These are the people who sent to me the tidings of eternal life."

After his death the book he had prepared lay for some time unpublished,-money was scarce, and perhaps the spirit of enterprise was low; but in I886 Mr. Crossett, of an American Society, borrowed it, and was so struck with its eloquence and learning that he had it printed at the Mission press in Pekin, and the leading missionaries in the north-Revs. Drs. Martin, Edkins, Blodgett - and others, ordered several hundreds of copies. Many others were sent to southern stations ; and thus old Wang, being dead, yet speaketh.

Mr. Hu was born in a large city near the mouth of the river Peiho. His father was a flourishing merchant, who owned several seagoing junks. He gave his son a good education, and trained him for a business life. He became supercargo of one of his father's ships, but while on a voyage to the south one day pirates boarded the ressel, robbed him of all he had in the world, and he was cast ashore at Shanghai penniless, and had to seek other employment. He became a teacher of northern Mandarin to students for the consular service, one of his pupils being Mr. Morrison, a younger son of the subject of this 
memoir. One day, as he wandered along the main street of the city, he saw a mission chapel with open doors, and a foreigner speaking to a congregation of people. Impelled by curiosity he entered and listened to the message. $\mathrm{He}$ repeated his visit, and obtained a copy of the Holy Scriptures, which he carefully read. The Lord opened his heart, he became a sincere believer in Jesus Christ, and united himself with the church where he had first heard the Word of Life. Soon after this he became possessed with a desire to return to the neighbourhood of his early days, and he left Shanghai, carrying with him letters of recommendation to the missionaries in the town to which he was going. On arriving there he went to the mission church and presented his letters of introduction. The agents who received him were at that time offering special prayer to God that some one might be given to them to help in the work which was opening out before them. They welcomed Mr. Hu, and he quickly proved himself to be a devoted and able helper. He was a man of fine presence, he had an excellent voice and style of speaking, he was intelligent and courageous, and as he became familiar with the truths of the Gospel he proved himself to be a preacher of extraordinary power. Soon after his ordination to the work of the ministry a very wonderful revival of religion broke out in a number of towns and villages in the northern part of the province of Shantung, and Mr. Hu was sent to inspect and take charge of the work. He went, and for about twelve years he laboured with untiring zeal, going round the district as an evangelist, superintending the building of chapels, kecping the accounts of the various churches, and fulfilling all the duties of a pastor with extraordinary diligence and success. After a tour through the eastern portion of his district, he was smitten down with sickness which proved to be fatal. $\mathrm{He}$ manifested the utmost calmness and cheerfulness, and when the end was approaching he placed his hand on his heart 
and said, "ALL IS PEACE HERE," and with this testimony to the efficacy of redeeming love he passed from earth to heaven.

Mr. Wong was a young landscape painter in a large city in the province of Fuh-kien. An intimate friend of his named $\mathrm{Hu}$, also a painter, was a Christian and a member of the church. After much prayer and persuasion he induced Wong to read the Bible and attend the services. Results were soon manifest. Wong's mother, who was tenderly attached to her son, was warned that something was wrong, and that he should be looked after. "What is wrong?" she said; "my son has always been industrious and dutiful: what has happened?" "He attends foreign churches." "Impossible!" she cried; "it cannot be that my son would do such a thing." On questioning him she found to her horror it was too true, and he declared that he found what the foreigners said to be "very reasonable."

It needs some familiarity with social life in China to understand the power of the parent over a son in mature life. She kept him closely confined to the house, and tried in every way to shake his determination, weeping, scolding, and threatening by turns. But all was of no avail, and her wrath grew more intense as she heard him praying, "Lord, bless my mother," and continually invoking the name of Jesus. At last she said, "Son, you must stop this praying." "Mother," he replied, "I have always obeyed all your commands, but this I cannot do." "But the noise disturbs me." "'Then I will pray silently." "You shall never pray in this house again." "Mother," said Wong, "I cannot stop praying." "Leave the house then," she exclaimed; "I disown you for ever as my child, and when I die dare not to join with the family in celebrating my funeral rites."

Wong was driven from the house, but not from his faith. $\mathrm{He}$ went and lived with his friend $\mathrm{Hu}$, and rapidly grew in knowledge and grace. One day his mother sent to bid him come to her. He could only think it was a plot to seize 
and kill him, but after a painful mental struggle he said to his minister, "I will go ; pray for me." He went. The mother asked him if he was still determined to be a Christian. "Mother," he said, fully expecting some assault, "I am." "Then," she said, "if you will not change your mind I will change mine. You may be a Christian and you may live at home." Overwhelmed with joy, Wong fell on his knees and thanked God.

For some months he continued his occupation as a painter, and was then taken into the service of the Mission, and laboured zealously as an evangelist for about four years. Then a discussion arose amongst the missionaries about the right term to use in Chinese for "God," and a word was imposed on the agents which Wong could not conscientiously use. He resigned his office, but shortly afterwards joined another Society, which not only gladly employed him, but ordained him to the ministry, the members of his former communion expressing their hearty concurrence in his reception. Thus the Chinese are proving by their steadfastness and zeal that the Gospel can find as good material to operate upon in that empire as anywhere under the sun.

The most difficult and yet the most pressing need of missions in China is to obtain access to the women of the land.

Women are generally excluded from society. Elderly females are allowed considerable freedom; but all the younger ones, and more especially the unmarried, are held by rigid etiquette to such complete retirement that it is of ten difficult to get them to attend public worship, and this notwithstanding the fact that the women assemble in a separate compartment, where they cannot be seen by the men. They do not take their meals with the men of the household. If you visit a Chinaman's house, you do not see the ladies. Unless some degree of intimacy exists, it is impolite to ask after the health of a Chinaman's wife or daughter. 
Public sentiment is against teaching women to read. There are some few among the higher classes, but not many, who can read. You seldom meet with one, except such as has been educated in mission schools. It is very seldom you meet with a woman having any desire to learn to read. Again, they have very little leisure time. In rural neighbourhoods the women work harder than the men. They spin cotton and weave cloth. They are the cooks and tailors and dressmakers of the household. They seldom work in the fields; but when the crops are brought in they take their full share of work at threshing, winnowing; and grinding. All this in spite of their little feet disqualifying them for any great activity. The only females who have any spare time are the old women; and teaching them to read is almost, if not quite, out of the question.

At the same time the women form a very important element of society. Their influence in the household, as in England, counts for a great deal. Having far less knowledge, they are far less under the influence of Confucian ideas, the most conservative ideas in the Empire. Their nature is much more religious than that of the men. The men trifle with their beliefs; the women are in earnest. They are capable of a practical faith, the men much less so. As a rule the male part of the family are Confucian, the women Buddhists or Taoists. It is they who visit the temples. The incense pots which smoulder before the placid.countenance of Buddha are filled and kindled by them. It is they who may be seen prostrating and $\mathrm{K}$ 'ô 'T'owing before the monstrous images alike of general and local deities. They burn ten sheets of paper to the men's one. Left to the men, Fo Yeh, the San Ch'ing, the eighteen Lo Huns, Kuan Yin, Kuan Yün Ch'iang, the god of medicine, the god of wealth, the innumerable P'u Sah, all the countless host of the Chinese Pantheon, would have crumbled on their seats and been buried under the undistinguishable ruins of their own temples long ago. When the men 
pretend to worship them they only play at it. But the zeal of the women has kept alive the faith in these grotesque and senseless deities, and supplied the impulse which from time to time has reconstructed their broken shrines and renovated their falling habitations. On this account they make much better Christians than the men. The men are satisfied with the cold abstractions and moral maxims of Confucianism, are interested in nothing higher than the earth or wider than the bounds of human life; the women must have something warmer and more emotional-they have deep cravings for the spiritual and the ctcrnal. The men talk about their religion much, but practise it little; the women feel their religion, and hence practise it. The men can do without worship, the women cannot. Farnest idolaters makc earnest Christians. The affections and aspirations which clung around and sanctified imaginary and superstitious beings, transferred to a living Christ and a God of eternal love, are the impulse to a new and holy life. Indifferent heathens make indifferent Christians. The habits of insincerity and practical scepticism which through a lifetime have been associated with a false faith are too often, on their conversion, retained in connection with the true.

Until woman, as the ruling power in the home and the influential factor in moulding the successive generations of China, is grasped and sanctified by the Spirit of Christ, the work of the missionary will be largely in vain; but as in other great onward Christian movements, lct the women be drawn into the Church, and the conquest of the Empire will be chiefly accomplished.

China is just now in a transition state, and is passing through the greatest crisis of its history. Old things are passing away, and all things are becoming new. Institutions and customs of slow growth, hoary with age, are tottering to their fall. Old superstitions, with which the life of the reople is inoculated, are losing their hold, and the nation 
is like a giant roused from a long stupor-a stupor which missionaries with their Divine message have had some share in breaking. Now a strange and undefined feeling is leading the nation to desire better things than she has had in the past. There must now go on a great fight between the new and the old. The intrusion of foreigners, and the introduction of Western modes of civilisation and of war, must change the social and political life of the people. The breaking up of old religious ideas and practices must affect the Empire either for better or for worse. That it may be for the better in every possible sense we must Christianise China through its length and breadth. We have been in the last hundred years training small detachments of Christian soldiers, and doing much preparatory work; but now the cry for more help and multiplied workers deepens itself, and comes from every province and every city.

Shall England, that in the opium traffic and the opium wars has so deeply cursed China, not have mercy and extend towards it the love of Christianity?

Buddhism is a religion of mercy in Asia. She has a concrete embodiment of a beautiful idea in the goddess of mercy with a thousand arms, a relief for the thousand ills of life. But Christianity has the more effectual relief for these ills in living agencies and beneficent institutions. There is no power that conciliates men like love, no force that can save like love. It is the power of God.

The cry is truly a Macedonian call from China. It is a cry from a "man," mighty for untold and incalculable good, but without the Gospel a curse to himself and the world. It comes from the deepest need of the most ancient and populous nation of the world. It comès from all classes, of false creeds and of no creed. It comes from myriads of infants who come to an untimely end, because of the misfortune of their sex or deformity. It is the sobbing, yearning cry of women oppressed by degrading wrongs, and who never knew the true blessedness and dignity of 
womanhood. It is the cry of millions of the poor, lame, and blind. It expresses the yearning of spirits to be delivered from a bondage of corruption into a Divine liberty. It is the language of a widely diffused and undefined feeling and striving after a higher Someone, albcit along a road of torturing idolatry and asceticism that they may flee from a wrath to come or an abyss of nothingness. It is the cry of a strong man bound and crippled, his eyes put out, and crushed into almost utter hopelessness, but who in his last extremity stretches out piteous hands for a Healer, a Deliverer, a Saviour, and pleads "Oh that I knew where I might find Him !"

The answer to the piteous cry for help which comes from China, and, indeed, from all parts of the heathen world, can only be supplied by the thorough consecration of the zehole Church to the advancement of Christ's kingdom. As 1)r. Stevenson says: "The Church has been consecrated to this work by its Master; and when the consecration is accepted, penetrating not only into assemblies and councils, but into every little group of Christian people-penetrating like a fire that burns into men's souls, and then leaping out in flames of impulse and passionate surrender-we shall see the Mission as Christ would have it be. The story of it will be told from every pulpit; it will be the burden of daily prayer in every Christian home ; every one will study. for himself, as Canon Westcott recommends, the annals of the present conquests of the Cross; the children will grow up believing that this is the aim for which they are to live, and churches will meet to plan their great campaigns, and send out the best and ablest men they have to take part in this war of love. It will be the cause of the hour into which men will pour all that they would spend on the greatest struggle they have ever known. It is time for the Church to ask for this consecrated spirit, to ask for the entire congregation the consccration that is asked and expected of the single man or woman whom it sends into the field." 
A year ago four hundred and thirty missionaries met in conference in Shanghai to consider the extension of missions in China. It was attended by many of the most venerable agents in the field, and for several days the members occupied themselves in prayerful and solemn consideration of living subjects touching the conversion of the empire of China. The main outcome of the Conference was the resolve to make a fervid appeal to the Christian world for multiplied agents, and the following touching and powerful address has been issued. That its trumpet-tongued words may vibrate sympathetically in the hearts of all the readers of this volume is the earnest prayer of the writer.

\section{En Elppeal for One Thousand SIDen.}

\section{To all Protestant Churchmen of Christian Lands.}

Dear Brethren in Christ,-

We, the General Conference of Protestant Missionaries in China, having just made a special appeal to you for a largely increased force of ordained Missionaries to preach the Gospel throughout the length and breadth of this great land,- to plant Churches, to educate native ministers and helpers, to create a Christian literature, and in general to engage in and direct the supreme work of Christian evangelisation, and

Having also just made a special appeal to you for a largely increased force of unordained men, evangelists, teachers, and physicians, - to travel far and wide distributing books and preaching to the masses, to lend a strong helping hand in the great work of Christian education, and to exhibit to China the benevolent side of Christianity in the work of healing the sick;

Therefore, we do now appeal to you, the Protestant Churches of Christian lands, to send to China in response to these calls- 


\section{ONE THOUSAND MEN WITHIN FIVE YEARS FROM THIS TIME.}

We make this appeal in behalf of three hundred millions of unevangelised heathen; we make it with the earnestness of our whole hearts, as men overwhelmed with the magnitude and responsibility of the work before us; we make it with unwavering faith in the power of a risen SAviour to call men into His vineyard, and to open the hearts of those who are His stewards to send out and support them, and we shall not cease to cry mightily to $\mathrm{Him}$ that $\mathrm{He}$ will do this thing, and that our eyes may see it.

On behalf of the Conference,

$$
\begin{aligned}
& \text { Chairmen }\left\{\begin{array}{l}
\text { Rev. J. L. Nevius, D.D. } \\
\text { Rev. D. Hill. }
\end{array}\right. \\
& \text { Permanent }\left\{\begin{array}{l}
\text { Rev. J. Hudson Taylor. } \\
\text { Rev. WM. Ashmore, D.D. } \\
\text { Kev. H. Corbett, D.D. } \\
\text { kev. C. W. Mateer, D.D., LL.D. } \\
\text { Rev. C. F. Reid. }
\end{array}\right.
\end{aligned}
$$

Shanghai, May, x 590.

Dr. Griffith John, in addressing a company of young men on his recent visit to England, spoke these words, with which this volume may fitly end:-

" It is not my habit to say anything to induce young men to devote themselves to this work, for I have a wholesome dread of man-inspired missionaries. But I cannot allow this opportunity to pass without telling you young men who are preparing for the ministry, that I thank God most sincerely and devoutly that I am a missionary. I have never regretted the step I took many years ago in opposition to the strongly expressed wish of my best friends; and if there is a sincere desire burning within my breast, it is that I may live and die in labouring and suffering for Christ among the heathen. Oh, it is a glorious work! I know 
no work like it,-so real, so unselfish, so apostolic, so Christ-like. I know no work that brings Christ so near to the soul, that throws a man back so completely upon God, and that makes the grand old, Gospel appear so real, so precious, so divine. And then think of the grandeur of our aim ! Our cry is, China for Christ! India for. Christ! The world for Christ! Think of China and her hundreds of millions becoming our Lord's and His Christ's! Is there nothing grand in the idea? Is there nothing soul-stirring in the prospect? Is not that an achievement worthy of the best efforts of the Church and of the noblest powers of the most richly endowed among you? And then "think of the unspeakable privilege and honour of having a share in a work which is destined to have such a glorious issue. Oh ! young men, think of it, dwell upon it; and if you hear the voice of God bid you go, manfully take up your cross and go, and you will never cease to thank Jesus Christ our Lord for counting you worthy to be missionaries."

THE END.

Frinted by Hazell, Watson, \& Viney, Ld, London and Aylesbury. 





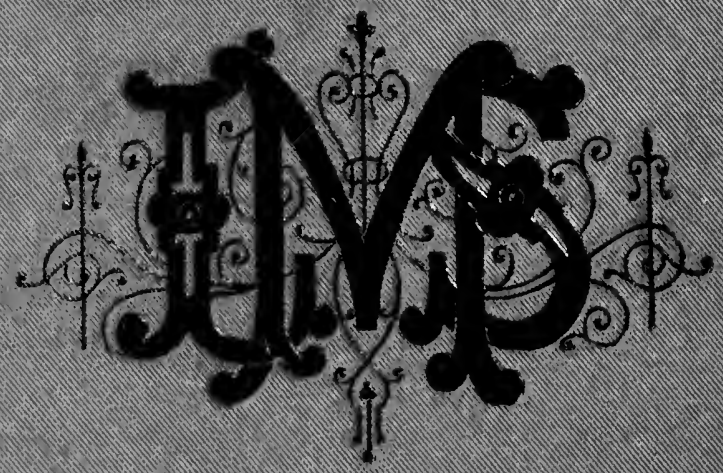

